This report was prepared as an account of work sponsored by an agency of the United States Government. Neither the United States Govermment nor any agency thereof, nor any of their employees, makes any warranty, express or implied, or assumes any legal liability or responsibility for the accuracy, completeness, or usefulness of any information, apparatus, product, or process disclosed, or represents that its use would not infringe privately owned rights. Reference herein to any specific commercial product, process, or service by trade name, trademark, manufacturer, or otherwise does not necessarily constitute or imply its endorsement, recommendation, or favoring by the United States Government or any agency thereof. The views and opinions of authors expressed herein do not mecessarily state or reflect those of the ONWI-479 Distribution Category UC=70

$O I T I T-479$

United States Government or any agency thereof.

\title{
Selection and Durability of Seal Materials for a Bedded Salt Repository: Preliminary Studies
}

\author{
Technical Report
}

November 1983

\author{
D. M. Roy \\ M. W. Grutzeck \\ L. D. Wakeley \\ of \\ Materials Research Laboratory \\ The Pennsylvania State University \\ prepared for \\ Office of Nuclear Waste Isolation \\ Bathelle Memorial Institute \\ 505 King Averue \\ Columbus, OH 43201
}

The content of this report was effective as of August 1983. This report was prepared by Materials Research Laboratory, The Pennsylvania State University under Subcontract E512-04200 with Battelle Project Management Division, Office of Nuclear Waste Isolation under Contract Nos. DE-AC0676RLO1830 and DE-AC02-83CH10140 with the U.S. Department of Energy. 


\section{DISCLAIMER}

This report was prepared as an account of work sponsored by an agency of the United States Government. Neither the United States Government nor any agency Thereof, nor any of their employees, makes any warranty, express or implied, or assumes any legal liability or responsibility for the accuracy, completeness, or usefulness of any information, apparatus, product, or process disclosed, or represents that its use would not infringe privately owned rights. Reference herein to any specific commercial product, process, or service by trade name, trademark, manufacturer, or otherwise does not necessarily constitute or imply its endorsement, recommendation, or favoring by the United States Government or any agency thereof. The views and opinions of authors expressed herein do not necessarily state or reflect those of the United States Government or any agency thereof. 


\section{DISCLAIMER}

Portions of this document may be illegible in electronic image products. Images are produced from the best available original document. 


\section{ili}

\section{ACKNOWLEDGMENTS}

The authors would like to acknowledge the contributions of: E. L. White,

J. J. Howard, S. Komarneni, B. E. Scheetz, P. H. Licastro, M. W. Barnes, and D. Wolfe-Confer. 
- 


\section{iiiliv}

ABSTRACT

This report details preliminary results of both experimental and theoretical studies of cementitious seal materials for use in a proposed nuclear waste repository in bedded salt. Effects of changes in bulk composition and environment upon phase stability and physical/mechanical properties have been evaluated for more than 25 formulations. Bonding and interfacial characteristics of the region between host rock and seal material or concrete aggregate and cementitious matrix for selected formulations have been studied. Compatibilities of clays and zeolites in brines typical of the SE New Mexico region have been investigated, and their stabilities reviewed.

Results of these studies have led to the conclusion that cementitious materials can be formulated which are compatible with the major rock types in a bedded salt repository environment. Strengths are more than adequate, permeabilities are consistently very low, and elastic moduli generally increase only very slightly with time. Seal formulation guidelines and recommendations for present and future work are presented. 

page

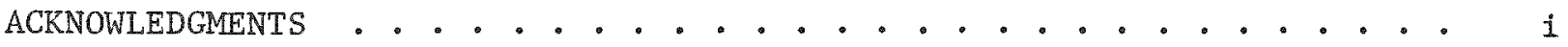

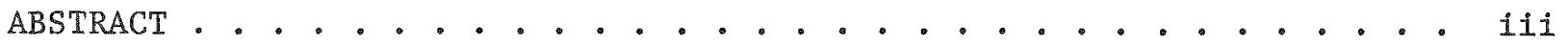

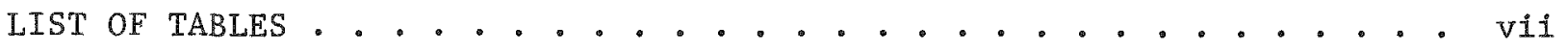

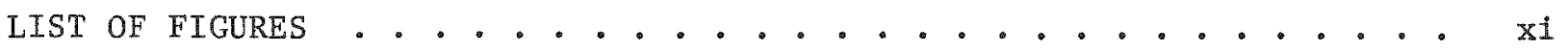

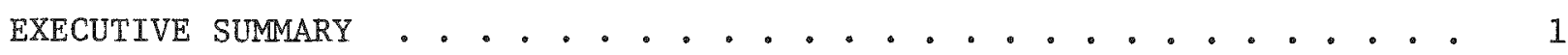

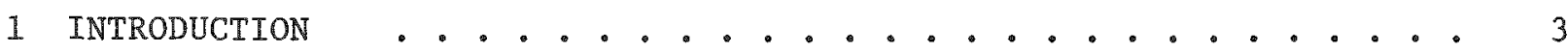

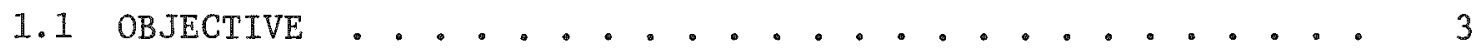

1.2 MATERIALS SELECTION, PLACEMENT AND LONGEVITY • . . . . . . . 3

1.3 ORGANIZATION OF REPORT . . . . . . . . . . . . . . . . . . 4

2 REPOSTTORY ROCK - . . . . . . . . . . . . . . . . . . . . . . . 5

2.1 LITHOLOGY •. . . . . . . . . . . . . . . . . . . . . 5

2.2 CHARACTERIZATION . . . . . . . . . . . . . . . . . . . . 6

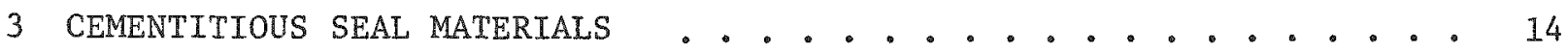

3. 1 SALT-CONTAINING SEAL MATERIALS AND DERIVATIVE MIXTURES . .15

3.1.1 Introduction ................. 15

3.1 .2 Viscosity .................... 16

3.1.3 Formulations . . . . . . . . . . . . . 16

3.1 .4 Results..................... . . . 19

3.1.5 Discussion and Conclusions . . . . . . . . . 38

3.2 FRESH WATER MIXTURES WITH POZZOLANIC ADMIXTURES . . . . . . 40

3.2 .1 Introduction . . . . . . . . . . . . . 40

3.2.2 Nature of the Pozzolanic Reaction . . . . . . . . 40

3.2.3 Design of Experimental Cementitious Mixtures . . . 41

3.2 .4 Viscosity . . . . . . . . . . . . . . . 42

3.2.5 Formulations ................. 42

3.2 .6 Results..................... 45

3.2.7 Discussion .................. 60

3.3 EXPLORATORY MTXTURES . . . . . . . . . . . . . . . . . . 61

3.3.1 Introduction .................. 61

3.3.2 Viscosity....................... 61

3.3.3 Formulations . . . . . . . . . . . . . 61

3.3 .4 Results . . . . . . . . . . . . . . . 62

3.3.5 Summary and Discussion . . . . . . . . . . . 79

$3.4 \mathrm{CaCl}_{2}+\mathrm{NaCl}$ MTXTURES . . . . . . . . . . . . . 82

3.4 .1 Introduction .................. 82

3.4 .2 Rationale for Mixtures . . . . . . . . . . . 85

3.4.3 Formulations ................. 86

3.4 .4 Results . . . . . . . . . ........ 88

3.4 .5 Discussion . . . . . . . . . . . . . 95 
page

3.5 CEMENT-BASED COMPOSITES/CONCRETE CONTAINING AGGREGATE FROM EVAPORITE STRATA ................. 99

3.5.1 Selection of Aggregates . . . . . . . . . . 99

3.5.2 Concrete Mixture Formulations . . . . . . . . 100

3.5.3 Casting and Curing Composites ......... 100

3.5.4 Testing Composites: Methods and Results . . . 102

3.5.5 Special Combinations of Cements and Rocks . . . 105

3.5 .6 Summary ................ 106

4 EARTH MATERIALS .................. 107

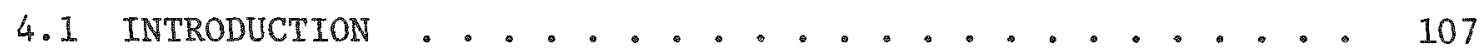

4.2 NATURAL ANALOGS-CLAY MINERALS IN SALT . . . . . . 108

4.3 ALTERATION OF CLAY MINERALS AND ZEOLITES IN BRINES AT ELEVATED TEMPERATURES AND PRESSURES . . . . . . . 113

4.3.1 Introduction ................ 113

4.3.2 Experimenta1 ............. 113

4.3.3 Results and Discussion .......... 117

4.3.4 Conclusions ............. 125

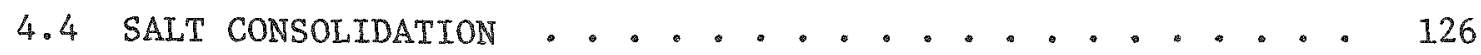

5 STABILITY: OBSERVATIONS AND IMPLICATIONS

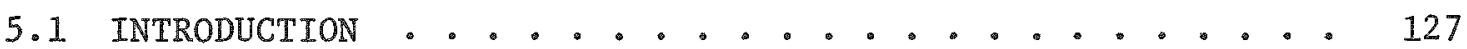

5.2 EFFECT OF VARIOUS ENVIRONMENTS ON PROPERTIES OF CEMENTITIOUS MIXTURE 80-081 .......... 127

5.3 EFFECT OF TEMPERATURE/PRESSURE AND NaC1 ON ETTRINGITE STABILITY AND CHLOROALUMINATE (FRIEDEL'S SALT) FORMATION • 131

5.3.1 Introduction . . . . . . . . . . . . 131

5.3.2 Results and Discussion ............ 132

5.3.2 Conclusions ............ 135

5.4 INTERFACE REACTIONS . . . . . . . . . . . 135

5.4 .1 Introduction .............. 135

5.4.2 Interfacial Studies ............ 136

5.5 DIFFUSION STUDIES; KINETICS . . . . . . . . . . 141

6 CONCLUSIONS AND RECOMMENDATIONS

REFERENCES . . . . . . . . . . . . . . . . . 149

APPENDICES . . . . . . . . . . . . . . . . . 155

APPENDIX A: CHEMICAL ANALYSIS ............. 156

APPENDIX B: MICROHARDNESS ............. 157 
vii

\section{LIST OF TABLES}

Table

page

2.1.1 Stratigraphy, 1ithology, and mineralogy of Los Medaños

core segments ..................... 7

2.1.2 Mineralogy and lithologic descriptions of gravels . . . . . 8

2.2.1 Data from separation of water-insoluble residues,

Los Medaños core segments . . . . . . . . . . . . 10

2.2.2 Mineralogic changes determined by DSC and TGA for rocks

and grouts ......................... 11

2.2.3 Measured permeability values for evaporite-site rocks . . . . 12

2.2.4 Specific gravity and absorption and packing density . . . . . 12

2.2.5 Pore sizes of samples of sandstone, anhydrite, and

salt aggregate ................... 12

2.2.6 Composition of WIPP-B brine (E17) . . . . . . . . . . 13

3.1.1 Apparent viscosity (cP) measured at $117 \mathrm{sec}^{-1}$ shear of

salt and salt derivative mixtures . . . . . . . . . .

3.1.2 Formulations of salt-containing and derivative

mixtures (grams) . . . . . . . . . . . . . . . . .

3.1.3 Compressive strength of salt-containing and derivative

mixtures (MPa) ................ 20

3.1.4 Bulk density of salt-containing and derivative mixtures .... 22

3.1.5 Permeability to water of 80-081 expansive cement cured at

$38^{\circ} \mathrm{C}$ (darcys, $\left.4 \mathrm{~m}^{2}\right)$..................

3.1.6 Water permeability of mixtures $81-030$ and $81-091$ as a

function of temperature and curing conditions (darcys $\cong \mu \mathrm{m}^{2}$ ) .

3.1.7 X-ray diffraction data for expansive cement pastes containing varying amounts of water . . . . . . . . . . 26

3.1.8 X-ray diffraction data for derivative mixtures . . . . . . 27

3.1.9 X-ray difraction data for silica and class F fly ash-

3.1.10 Thermal conductivity of mixture 81-091 as a function of

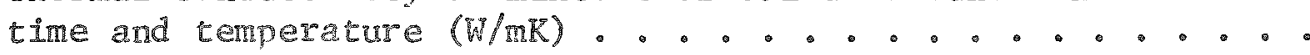

3.2.1 Apparent viscosity (CP) at $117 \mathrm{sec}^{-1}$ shear of pozzolanic cements ......................... 
viii

LIST OF TABLES (continued)

Table

page

3.2.2 Formulations of pozzolan-containing mixtures (weights in

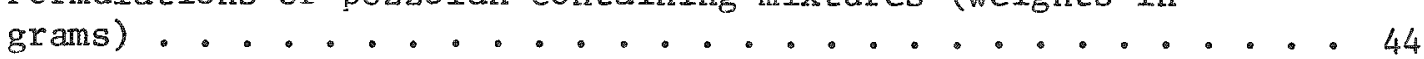

3.2.3 Compressive strength of pozzolanic mixtures (MPa) . . . . . 46

3.2.4 Bulk density of pozzolanic mixtures . . . . . . . . . . 49

3.2.5 Water permeabilities of fume- and dust-substituted cements $\left(\right.$ darcy $\left.\cong \mu m^{2}\right)$.............. 50

3.2.6 Water permeability of complex fume- and dust-substituted cements (darcys $\cong \mu \mathrm{m}^{2}$ ) ................. 51

3.2.7 X-ray diffraction phase data for samples cured at $38^{\circ} \mathrm{C}$ in $\mathrm{Ca}(\mathrm{OH})_{2}$ solution . . . . . . . . . . . . . . . . 52

3.2.8 X-ray diffraction data for fume- and dust-substituted cements . . . . . . . . . . . . . . . . . 54

3.2.9 X-ray diffraction data for ferrosilicon dust + slag- and silica fume + fly ash-substituted cements . . . . . . . 55

3.3.1 Apparent viscosity (CP) at $132 \mathrm{sec}^{-1}$ shear of exploratory mixture 81-010 .................. 62

3.2.2 Formulation of exploratory mixes . . . . . . . . . . 62

3.3.3 Compressive strength of exploratory mixtures (MPa) . . . . . 64

3.3.4 Bulk density of exploratory mixtures . . . . . . . . . . 65

3.3.5 Water permeability data for mixtures 81-010 and 80-010 $\left(\right.$ darcy $\left.\cong \mu \mathrm{m}^{2}\right)$................... 67

3.3.6 X-ray diffraction data for sandy grout $81-010$. . . . . . 68

3.3.7 X-ray diffraction phase data for samples cured in a saturated $\mathrm{Ca}(\mathrm{OH})_{2}$ solution . . . . . . . . . . . . 69

3.3.8 X-ray diffraction data for ferrosilicon dust-substituted cements .................. 71

3.3.9 X-ray diffraction phase data for samples cured in saturated $\mathrm{Ca}(\mathrm{OH})_{2}$ solution ............. 72

3.4.1 Mixtures for salt repository strata . . . . . . . . . . 87

3.4.2 Compressive strength of chloride mirtures (MPa) . . . . . . 89

3.4.3 Bulk density of chloride mixtures (MPa) . . . . . . . . . 89 


\section{LIST OF TABLES (continued)}

Tab1e

page

3.4 .4 Permeability data for salt strata mixtures cured at $60^{\circ} \mathrm{C}$ in WIPP-B brine (darcy $\cong u^{2}$ ) .............. 91

3.4.5 X-ray diffraction phase data for salt strata mixtures . . . . 96

3.4.6 Restrained and unrestrained curing of salt strata mirtures . . 97

3.4.7 Dynamic Young's modulus $\left(10^{6} \mathrm{psi}\right)$ of $\mathrm{NaCl}$ and $\mathrm{CaCl}_{2}$ mixtures . 98

3.5.1 Components of grouts and mortars used for composites with evaporite-sequence aggregate . . . . . . . . . . 101

3.5.2 Combinations of aggregates and cementitious formulations . . 101

3.5.3 Compressive strength (MPa) measured for composites with $\mathrm{NaCl}$ and $\mathrm{CaCl}_{2}$................. 103

3.5.4 Bulk density $(\mathrm{g} / \mathrm{cc}$ ) and porosity of composites . . . . . . 104

3.5.5 Measured permeability of concrete composite samples (38 curing) . . . . . . . . . . . . . . . 104

3.5.6 Measured permeability: interface samples . . . . . . . 106

4.3.1 Names, locations, sources, particle sizes of potential backfill samples . . . . . . . . . . . . . . 114

4.3.2 X-ray diffraction analyses of untreated and hydrothermally altered minerals ................ 118

4.3.3 Specific sorption of $\mathrm{Cs}$ and $\mathrm{Sr}$ as affected by the hydrothermal alteration of backfills in saturated NaCl brine . 120

4.3.4 Concentrations of $\mathrm{Si}$ and $\mathrm{Al}$ in the capsule fluids after hydrothermal treatments . . . . . . . . . . . 122

4.3.5 Specific sorption of $C s$ and $\mathrm{Sr}$ as affected by the hydrothermal alteration of backfills in Mg-rich brine . . . . 124

5.2.1 Curing environments of mixture 80-081 . . . . . . . . . 128

5.2.2 Compressive strength $\pm \sigma$ of $50.8-m m$ cubes cured in
various environments at 180 days (MPa) . . . . . . . . . 128

5.2.3 $\mathrm{X}$-xay diffraction data. .............. 130

5.4.1 Shear bond strength of mixtures cast in rock cylinders (MPa) . 138

5.6.1 Molalities and activity ratios at $25^{\circ} \mathrm{C}$ in Los Medanos waters, calculated from compositions given by Powers (1978) . . . . . 143 


\section{LIST OF TABLES (continued)}

Table

page

5.6.2 Stability of mineral phases in Los Medaños waters at $25^{\circ} \mathrm{C}$. 144

5.6.3 Stability of cement phases in brines; brine composition

from Powers (1978) . . . . . . . . . . . . . 145

Appendices

A Chemical analysis .................. 156

B Microhardness ................. 157 
Figure

page

3.1.1 SEM images of 7 -day cured $60^{\circ} \mathrm{C}$ vacuum-dried shell-vial samples of mixture 80-081 . . . . . . . . . . . . . .

3.1.2 SEM images of 90-day "as-cured" shel1-via1 cured samples of mixture 80-081 . . . . . . . . . . . . . . 30

3.1.3 SEM images of mixture $81-091$ cured at $60^{\circ} \mathrm{C}$. . . . . . 33

3.1.4 Unidimensional change of mixtures 79-071 and 79-080 compared to a neat cement paste ............. 34

3.1.5 Unidimensional and volumetric change of mixture 81-091. Room temperature and $55^{\circ} \mathrm{C}$ hydration ........ 35

3.1.6 Dynamic Young's modulus for mixture 81-091 as a function of temperature ................... 36

3.1.7 Correlation of compressive strength with \% salt saturation of mixing water . . . . . . . . . . . . . . . . . .

3.2.1 Mechanism of hydration of a normal paste and a "silicafume-enhanced" paste ...................

3.2.2 Dynamic Young's modulus for mixture 80-020 hydrated at $60^{\circ} \mathrm{C}$ in saturated $\mathrm{Ca}(\mathrm{OH})_{2}$ solution

3.2.3 Unidimensional change of mixture $81-111$ as a function of sample length . . . . . . . . . . . . . 59

3.3.1 SEM Images of ASTM C 109 sand . . . . . . . . . . 73

3.3.2 Seven-day hydration of mixture 81-010 . . . . . . . . 74

3.3.3 Fourteen-day hydration of mixture 81-010 . . . . . . . . 76

3.3.4 SEM images of 7 -day, $27^{\circ} \mathrm{C}$ cured samples of mixtures

3.3.5 SEM images of 7 -day, $27^{\circ} \mathrm{C}$ cured samples of mixture 79-040. . 78

3.3.6 A comparison of compressive strength vs. water/cement (w/c) ratio to compressive strength vs. water/reactive solids $(w / s)$ ratio for selected cementitious mixtures ........

3.4.1 Schematic composition diagram of potential phase relations in the system $\mathrm{C}_{3} \mathrm{~A}-\mathrm{CaSO}_{4}{ }^{\text {"chloride" }}$. . . . . . . . . 84

3.4.2 SEM images for $38^{\circ} \mathrm{C}$ brine-cured samples of mixture 82-02 • • 92

3.4.3 SEM images of mixture 82-02 cured in various environments at room temperature and $38^{\circ} \mathrm{C}$ 
Figure

page

4.2.1 Stability relationship diagrams for several common low-temperature clay minerals calculated for the activity of several cations ( $\mathrm{K}^{+}, \mathrm{Na}^{+}, \mathrm{Mg}^{2+}, \mathrm{H}^{+}$) against silica activity .........................

4.3.1 X-ray powder diffractograms of hydrotherma11y altered zeolites in Mg-rich brine ..................

4.3.2 X-ray powder diffractograms of untreated and hydrothermally altered TX montmorillonite at $300^{\circ} \mathrm{C} / 30 \mathrm{MPa}$. A) untreated; B) altered partially to albite in NaCl brine after 12 weeks; C) altered to randomly interstratified montmorillonite/illite after 4 weeks; D) altered to randonly interstratified montmorillonite/illite after 12 weeks . . . . . . . . . . . . . . . . .

5.3.1 Stability of ettringite under high temperature and high pressure in deionized water..............

5.3.2 Stability of ettringite under high temperature and high pressure in $20 \% \mathrm{NaCl}$ solution ...........

5.5.I Diffusion coefficients for $\mathrm{Na}^{+}$and $\mathrm{CI}^{-}$in cement paste. Activation energies for diffusion are given. . . . . 


\section{EXECUTIVE SUMMARY}

The preliminary results of studies relating to the durability/longevity of seal materials for a variety of environments expected in a bedded salt repository are detailed. Cementitious seal materials ranging in complexity from simple cement-sand mortars through complex non-conventional calcium chloride-containing cementitious materials, to concretes containing several aggregate types have been considered. This range of cementitious materials provides possible options for seals in strata of different rock types. Such materials may be considered for use as components of shaft and tunnel bulkheads, structural concrete and borehole plugs.

The sedimentary and evaporite rock types encountered in such a salt repository have been grouped as follows: salt strata consisting of nearly pure sodium chloride; various thicknesses of carbonate, sulfate and clay strata members; and finally, silicate rock materials (both well consolidated and poorly consolidated). Each of these strata presents significantly different conditions, giving rise to the requirement that seal materials should be optimized to take advantage of the local host rock chemistry and physical characteristics.

The salt-containing mixtures, both expansive and nonexpansive, have been designed for compatibility with salt-dominated horizons. Moderate to high chloride and/or sulfate activities were characteristic of these mixtures. The permeabilities were consistently very low, and the mechanical properties more than adequate.

Probable limits to stabilities of some of the constituent phases have been set by theoretical and experimental thermodynamic considerations. Results of some diffusion studies suggest a means for determining rates of change under certain circumstances.

For less saline environments a number of mixtures were designed for intrinsic stability and for the potential to generate silicate-cement bonding. Reduction in free lime content (a relatively soluble component), to produce more stable cementitious materials, was achieved by reaction with silica and other pozzolans. As a consequence, and also through use of super water reducers, porosity and permeability were significantly reduced.

Observations on the compatibilities of these formulations in various environments were made by studying contacts with rock materials from a bedded 
salt region (either as concrete composites or as rock-cement pair samples). Clays and possibly zeolites and their composites are also likely to constitute components of shaft, tumel and borehole seals. Therefore, both theoretical and experimental studies addressed their behavior in brine solutions. Consolidation of salt, though not generally considered as a primary seal, may constitute the logical bulk backfill mechanism for repository rooms.

Results of the experimental program have demonstrated that cementitious materials suitable for all rock types in a salt environment can be formulated. Specific mixtures can be designed with specific properties to take advantage of the chemistry of the host rocks.

Conclusions and recomendations are presented, which give direction for Euture research. 


\section{INTRODUCTION}

\subsection{OBJECTIVE}

The acceptance of bedded salt as a viable nuclear waste repository will in part be dependent upon demonstration of the ability to effectively isolate those man-made penetrations, i.e. shafts, boreholes, and tunnels common to the repository site.

Candidate seal materials which show greatest potential from the standpoint of properties, performance and cost effectiveness are cement-based or earth-based; however, prior to utilization of such, a thorough understanding of their behavior in the host environment for extended periods of time is necessary.

Therefore, it has been our objective to formulate and evaluate potential seal materials specific to these environments. The evaluation of the durability and longevity of these materials will play a key role in determining the feasibility of such sites.

\subsection{MATERIALS SELECTION, PLACEMENT AND LONGEVITY}

From the outset, the objective has been to design seal materials which would be durable and long-lived and at the same time fairly easily emplaceable as well as inexpensive. Various feasibility studies were completed and a number of concepts, although meritorious, were discarded as either too expensive or presenting insurmountable engineering problems. Materials derived from portland cement and its mixtures have been the subject of primary attention, since they are major structural materials, versatile and inexpensive, and are based upon extensive practical experience and development. Complementary to these are clays or earth materials which are valued particularly for their deformability, swelling properties and radionuclide sorption/fixation. Consolidation of salt, which is expected to constitute a major portion of bedded salt repository backfill, has been discussed in other reports, and is discussed only briefly.

The cementitious seal materials investigated were designed for potential Iongevity, taking into consideration a number of properties and characteristics: 1) relative intrinsic thermodynamic stability; 2) feasible placement combined with adequate mechanical and physical properties; 3) minimizing permeability and implicitly radionuclide transport; and 4) other features relating to thermodynamics in the specific bedded salt environment, and kinetic factors used to 
evaluate potential phase changes. Most of these same factors were also considered in investigations of clay or earth materials.

\subsection{ORGANIZATTON OF REPORT}

The report is divided into sections, each dealing with a different aspect of seal materials. This first section is introductory, dealing with concepts, background, and the longevity problem. Section 2 provides information on characterization of rock from a bedded salt area in SE New Mexico. Section 3 treats specific seal materials containing salt, and additional seal materials which are probably compatible with other horizons and includes studies on concrete, solid-aggregate bonding, and interface characteristics. Section 4 deals with studies on the stability of earth materials in brine environments. Section 5 discusses various aspects of stability and durability. Section 6 provides conclusions and tentative recommendations. 


\section{REPOSITORY ROCK}

\subsection{LITHOLOCY}

Lithology of the host rock is one of the important factors considered in siting a waste repository (DOE, 1980; KIingsberg and Duguid, 1980). Each potential host-rock type presents a unique set of problems and advantages. Requisite to a study of compatibility between rock and cementitious or other repository-seal materials is thorough characterization of repository rocks. Properties of the host rock will to a great extent determine or constrain the use of certain substances for closure and sealing.

Rocks recovered from subsurface drilling at the Los Medanos site in southeastern New Mexico are the focus of our study. These rocks, although specific to one area of evaporites, provide appropriate examples of the lithologies generally encountered in evaporite strata. The proposed repository horizon in this region is within the Salado formation. This unit is 213 to $610 \mathrm{~m}$ thick and consists of beds of both relatively pure and clay-rich halite, and potassiumbearing minerals. With a thickness of over $1525 \mathrm{~m}$, the total evaporite sequence in this region includes several brine aquifers and complex interbeds of halide and sulfate minerals. Closure of a repository in this sequence will require sealing salt beds, anhydrite beds, aquifers, and carbonate and clastic units interlayered with and overlying the evaporites. The non-evaporite strata have physical and chemical properties very different to those of the Salado bedded salts.

Study of the repository rocks has not been limited to considering their sealing requirements. We have extended our efforts to include use of minedout host rock as backfill or concrete aggregate. Using the mined-out rock as a component of sealing composites is advantageous for several reasons. Foremost among these are:

1) The aggregate itself would enhance compatibility between host rock and seal materials. Such composites might more readily be made to share the best properties of the host strata.

2) Using mined-out rock on-site minimizes expensive transportation and handling.

The rock removed from tunnels and shafts may not fulfill the requirements of the plugs at certain horizons. Commercial aggregate available from near the repository site might then be the best choice for maximizing compatibility while minimizing materials handling. 
Table 2.1.1 is a summary of the mineralogy and lithology of the core segments studied. Some segments from the Santa Rosa, Dewey Lake, Salado, and Castile formations were crushed and sieved to provide coarse aggregate for cementitious composites. A commercial dolostone aggregate, mined at the surface in this region, was also studied and used. This served the dual purpose of allowing us to test compatibility of salt mixes with dolostone (there are dolostone beds in this sequence although we received no cores of it); and extending the scope of our study to include a near-site commercial aggregate, as mentioned above. Mineralogies and brief petrographic descriptions of the gravels used are given in Table 2.1.2.

\subsection{CHARACTERIZATION}

Many standard methods of characterization were used for core segments and aggregate. These tests and analyses are briefly described below, and the resulting data are presented in Tables 2.2.1 through 2.2.3. Additional detail of the methods of rock characterization was published previously (Wakeley et al., 1981a). Some methods were appropriate only to aggregates; others to rock as either host or aggregate.

$\mathrm{X}$-ray diffraction was employed to identify the minerals present in all core segments (three or more samples per core) and of the specific gravels used in composites. In addition, water-insoluble residues were isolated from many segments, and analyzed by x-ray diffraction. Isolation of these residues was especially useful for identifying accessory components in halite rocks, where NaCl preponderates whole-rock diffraction patterns. This procedure also allowed us to determine the percentage of soluble salts in different horizons (Table 2.2.1).

Clay minerals isolated by setting techniques (Folk, 1968) from segments of Dewey Lake and Salado core were treated with ethylene glycol. This method expands the lattice of expandable clays, causing an identifiable peak shift on diffraction patterns. Special $x$-ray studies of the clay-sized fractions of these rocks revealed the presence of chlorite and mixed-layer illite/smectite in Dewey Lake mudstone; and mixed-layer chlorite/smectite (corrensite) in some beds of the Salado evaporites. The hydrophilic nature of these expandable clays foretells a potential for absorbing water from cement pastes (discussed in Section 3.5). Section 4 includes other considerations of clay minerals.

Additional details of the mineralogies and fabrics of these rocks derived from study of petrographic thin sections with an optical microscope and polarized 
Table 2.1.1. Stratigraphy, 1ithology, and mineralogy of Los Medaños core segments.

\begin{tabular}{|c|c|c|c|c|c|}
\hline Core a & and Depth & Formation & $\begin{array}{l}\text { Apparent } \\
\text { Lithology }\end{array}$ & $\begin{array}{c}\text { (XPD) } \\
\text { Mineralogy* }\end{array}$ & Remarks \\
\hline \multirow[t]{8}{*}{$\mathrm{AEC}-8$} & $065-067$ & Santa Rosa & sandstone & $\begin{array}{l}\text { Qu Do II Ha } \\
\text { Ch He }\end{array}$ & $\begin{array}{l}\text { coarse and porous; } \\
\text { dolomite cement }\end{array}$ \\
\hline & $068-070$ & & sandstone & $\begin{array}{l}\text { Qu Do II Ha } \\
\text { Ch(?) He(?) }\end{array}$ & \\
\hline & $564-566$ & Dewey Lake & $\begin{array}{l}\text { gypsiferous } \\
\text { mudstone }\end{array}$ & $\begin{array}{l}\text { Qu Gy Do Ja } \\
\text { Mo Ch II Je }\end{array}$ & $\begin{array}{l}\text { green nodules, } \\
\text { and gypsum partings }\end{array}$ \\
\hline & $618-619$ & & $\begin{array}{l}\text { gypsiferous } \\
\text { mudstone }\end{array}$ & $\begin{array}{l}\text { Qu II Do Ch } \\
\text { He Gy }\end{array}$ & \\
\hline & $682-684$ & Ruscler & $\begin{array}{l}\text { coarse gray } \\
\text { anhydrite }\end{array}$ & An Ha Do & $\begin{array}{l}\text { very coarse } \\
\text { gypsum locally }\end{array}$ \\
\hline & $976-977$ & & gray siltstone & $\begin{array}{l}\text { Qu Ha } \mathrm{An} \mathrm{Ma} \\
\text { Ch II }\end{array}$ & unconsolidated \\
\hline & $1013-1015$ & Salado & silty halite & $\begin{array}{l}\text { Ha Qu An Do } \\
\text { (telays) }\end{array}$ & $\begin{array}{l}\text { very "dirty" in } \\
\text { lower part }\end{array}$ \\
\hline & [1065] & & [mised salts] & $\begin{array}{r}\text { (blocks from } \\
-P\end{array}$ & $\begin{array}{l}\text { vered core segment } \\
\text { Zone) }\end{array}$ \\
\hline \multirow[t]{17}{*}{$\mathrm{AEC}-7$} & $1685-1687$ & & silty halite & $\begin{array}{l}\text { Ha Qu } \\
\text { (tclays) }\end{array}$ & \\
\hline & $1688-1690$ & & & & \\
\hline & $1691-1692$ & & & & \\
\hline & $2998-3000$ & Castile & fine white anhyd. & An $\mathrm{Ma}$ & \\
\hline & $3003-3005$ & & $\begin{array}{l}\text { anhydrite and } \\
\text { clear halite }\end{array}$ & An Ha Do II & $\begin{array}{l}\text { very light color, } \\
\text { "clean" }\end{array}$ \\
\hline & $3006-3008$ & & halite & Ha Do & coarse clear xtls \\
\hline & $3011-3013$ & & $\begin{array}{l}\text { halite and } \\
\text { anhydrite }\end{array}$ & Ha An M ha & very light color \\
\hline & $3014-3015$ & & $\begin{array}{l}\text { anhydrice with } \\
\text { halite stringers }\end{array}$ & An Ha & white \\
\hline & $3016-3018$ & & & & \\
\hline & $3924-3925$ & & $\begin{array}{l}\text { dark gray } \\
\text { anhydrite }\end{array}$ & $\mathrm{Ar} \mathrm{Ha} \mathrm{Ca}$ & fine-grained, massive \\
\hline & $3928-3930$ & & & An & \\
\hline & $3933-3935$ & & & An & \\
\hline & $3937-3940$ & & & An & \\
\hline & $3942-3944$ & & & $\mathrm{ArI} \mathrm{Ca}$ & \\
\hline & $3947-3949$ & & & An & \\
\hline & $3952-3954$ & & & $\mathrm{An} \mathrm{Ca}$ & \\
\hline & $3957-3959$ & & & $\mathrm{An} \mathrm{Ca}$ & \\
\hline
\end{tabular}

*Mineral AbbreviatLons:

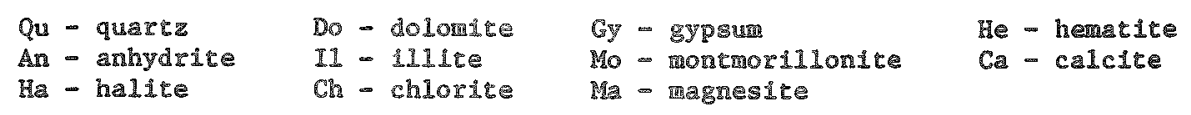


Table 2.1.2. Mineralogy and lithologic descriptions of gravels.

\begin{tabular}{|c|c|c|c|c|}
\hline Rock Type & Depth & Formation & Mineralogy (XRD)* & Description (optical microscopy) \\
\hline Dolostone & $\begin{array}{l}\text { mined at } \\
\text { surface }\end{array}$ & Dark Canyon & $\mathrm{Do}, \mathrm{Qu}, \mathrm{Ca}, \mathrm{He}$ & (commercial gravel; no 1ithologic study) \\
\hline Anhydrite & $\begin{array}{l}918 \mathrm{~m} \\
(3013 \mathrm{ft})\end{array}$ & Castile & $\mathrm{An}, \mathrm{Ma}, \mathrm{Ha}$ & $\begin{array}{l}\text { granular texture, non-porous; remnants of } \\
\text { massive halite }\end{array}$ \\
\hline Mudstone & $\begin{array}{l}172 \mathrm{~m} \\
(563-4 \mathrm{ft})\end{array}$ & Dewey Lake & $\begin{array}{l}\text { Qu, Gy, Do, Ha, Mo, } \\
\mathrm{Ch}, \mathrm{II}, \mathrm{He}, \mathrm{Sm}, \mathrm{I} / \mathrm{S}\end{array}$ & $\begin{array}{l}\text { clay matrix with fine-grained quartz, chert, } \\
\text { rock fragments; authigenic smectite filling } \\
\text { fractures }\end{array}$ \\
\hline Sandstone & $\begin{array}{l}20 \mathrm{~m} \\
(66 \mathrm{ft})\end{array}$ & Santa Rosa & Qu, Do, II, Ha, He, Ch & $\begin{array}{l}\text { dolomite-cemented quartz grains and rock } \\
\text { fragments; Fe stain in cement; coarse and } \\
\text { porous }\end{array}$ \\
\hline Halite & $515 \mathrm{~m}$ & Salado & $\mathrm{Ha}, \mathrm{Qu}, \mathrm{Co}$ & $\begin{array}{l}\text { massive blocky halite with inclusions; some } \\
\text { amorphous Fe-stained areas; traces of gypsum } \\
\text { locally along crystal boundaries }\end{array}$ \\
\hline
\end{tabular}

*Mineral Abbreviations:

$\begin{array}{llll}\text { Qu - quartz } & \text { Ha - halite } & \text { Il - illite } & \text { Mo - montmorillonite } \\ \text { An - anhydrite } & \text { Do - dolomite } & \text { Ch - chlorite } & \text { Ma - magnesite } \\ \text { Co- corrensite } & \text { I/S - mixed layer } & \text { Gy - gypsum } & \text { He - hematite } \\ & \text { illite/smectite } & \end{array}$


transmitted light. Some notable petrographic features of four rock types are 1isted in Table 2.1.2. Differential scanning calorimetry (DSC) and thermal analyses (TGS) confirmed mineral identification via other methods (Table 2.2.2). Compressive strength was measured for core segments of three rock types: sandstone (Santa Rosa) and mudstone (Dewey Lake), each about $20 \mathrm{MPa}$; and anhydrite (Castile), >80 MPa. Having been cored twice, once when recovered from the subsurface and again in preparation for testing, the rocks had been subjected to multiple episodes of physical shock. Therefore we assume that these measured values indicate lower strengths than field performance would show.

Permeability of the dolostone, anhydrite, sandstone, and halite were measured to various media at pressures of 0.69 to $4 \mathrm{MPa}$. Measured permeability values are reported in Table 2.2 .3 .

Specific gravity and absorption (ASTM C-127) and packing density were. determined for the commercial dolostone gravel and coarse aggregate of the same size range ( $12.7 \times 4.75-\mathrm{mm})$ derived from sandstone and anhydrite core segments (Table 2.2.4). Pore sizes of samples of sandstone, anhydrite, and salt aggregates were determined by mercury ( $\mathrm{Hg}$ )-intrusion porosimetry (Table 2.2.5). The very large pores of the sandstone were measured at low pressure; no pores were intruded at $>15.0$ psia. This porosity agrees well with the low specific gravity, low strength, and high permeability measured for this poorly cemented sandstone. The very low permeability of the anhydrite, as well as its high strength, are compatible with very small pore sizes. All measurements assume an Hg wetting angle of $140^{\circ}$.

The brine used most frequently for curing, and in some composites as the mixing water, is based on the average composition of water in which Salado bedded salt has been dissolved to saturation (WIPP-B, MRL number E17). These components in 1 liter of brine are summarized in Table 2.2.6. We used other types of brine in some specialized experiments. These are presented in discussions where appropriate. 
Table 2.2.1. Data from separation of water-insoluble residues, Los Medaños core segments.

\begin{tabular}{|c|c|c|c|c|}
\hline Formation & $\begin{array}{c}\text { Core Segment Depths, } \\
\text { Ft }\end{array}$ & $\begin{array}{l}\text { Water-Insoluble } \\
\text { Minerals, wt\% }\end{array}$ & $\begin{array}{l}\text { Mineralogy } \\
(\mathrm{XRD})\end{array}$ & $\begin{array}{l}\text { No. of Samples } \\
\text { Tested }\end{array}$ \\
\hline Rustler & $682-977$ & 84 to 92 & $\begin{array}{l}\text { Qu, II, Mo, } \\
\text { Ma, He }\end{array}$ & 5 \\
\hline Salado 1 & $\begin{array}{l}1013-1015 \\
1685-1692\end{array}$ & 2 to 28 & $\begin{array}{l}\text { Do, An } \\
\text { Qu, I1, Ch, } \\
\text { Ma, Gy, Do }\end{array}$ & $\begin{array}{l}1 \\
8\end{array}$ \\
\hline \multirow[t]{2}{*}{ Castile ${ }^{2}$} & $2998-3018$ & $\begin{array}{l}\text { for halite } 0.15 \text { to } \\
0.26 \\
\text { for anhyditte } 83 \\
\text { to } 92\end{array}$ & $\mathrm{An}, \mathrm{Ma}$ & 10 \\
\hline & $3924-3959$ & 86 to 96 & An & 10 \\
\hline
\end{tabular}

${ }^{1}$ Source of halite aggregate used in this study.

${ }^{2}$ Source of anhydrite aggregate.

${ }^{3}$ See Table 2.1.1 for key to mineral abbreviations. 
Table 2.2.2. Mineralogic changes determined by DSC and TGA for rocks and grouts.

sample

change indicated

A. DSC - SCANNED FROM 52 TO $>450^{\circ} \mathrm{C}$

dolostone

no peaks in range of scan, gradual energy increase (= endotherm)

sandstone same

mudstone energy input $90-130^{\circ} \mathrm{C}$ from dehydration of clays and gypsum

halite/mixed salt energy input $100-115^{\circ} \mathrm{C}$ dehydration of clays many small changes suggest the presence of blodite, leonite, polyhalite, but range of scan inadequate for positive identification

anhydrite

gradual energy increase ( $=$ endotherm) $270^{\circ}$ to $400^{\circ} \mathrm{C}$ (end of scan)

B. TGA - WEIGHT LOSS 25 TO $1000^{\circ} \mathrm{C}$

anhydrite

$3.3 \%$ weight loss (no gypsum indicated) break in slope $\sim 550^{\circ} \mathrm{C}$, clay dehydration

dolostone

$1.9 \%$ weight loss before dolomite decomposition

$11.6 \%$ weight $10 \mathrm{ss} 700^{\circ}$ to $840^{\circ} \mathrm{C}$ with decomposition of dolomite

$26.3 \%$ weight loss $840^{\circ}$ to $916^{\circ} \mathrm{C}$, no break in slope to indicate calcite 
Table 2.2.3. Measured permeability values for evaporite-site rocks.

\begin{tabular}{llll}
\hline Rock Type & Test Medium & \multicolumn{2}{c}{$\begin{array}{c}\text { Permeability } \\
\text { (darcy) }\end{array}$} \\
\hline cm sec-1)
\end{tabular}

*Simulated WIPP-B brine. See Table 2.2.6.

Table 2.2.4. Specific gravity and absorption and packing density.

\begin{tabular}{lccc}
\hline Gravel Type & Bulk Specific Gravity & Absorption, \% & Packing Density, \% \\
\hline dolostone & 2.74 & 0.5 & 48.3 \\
sand stone & 1.99 & 11.50 & 41.5 \\
anhydrite & 2.91 & 0.4 & 44.6 \\
\hline
\end{tabular}

Table 2.2.5. Pore sizes of samples of sandstone, anhydrite, and salt aggregates.

\begin{tabular}{lrc}
\hline Gravel Type & Size Range & Mode(s) \\
\hline $\begin{array}{l}\text { sandstone } \\
\begin{array}{l}1 \text { to } 50 \mu \mathrm{m} \\
\text { halite }\end{array}\end{array} \quad \begin{aligned} 11.5 \mu \mathrm{m} \\
7 \text { to } 2000 \AA\end{aligned}$ \\
\hline
\end{tabular}


Table 2.2.6. Composition of WIPP-B brine (E17) (grams/1iter).

\begin{tabular}{lc}
\hline $\mathrm{Na}_{2} \mathrm{~B}_{4} \mathrm{O}_{7} \cdot 10 \mathrm{H}_{2} \mathrm{O}$ & 0.016 \\
$\mathrm{SrCl}_{2} \cdot 6 \mathrm{H}_{2} \mathrm{O}$ & 0.045 \\
$\mathrm{NaHCO}_{3}$ & 0.13 \\
$\mathrm{KBr}$ & 0.045 \\
$\mathrm{MgSO}_{4} \cdot 7 \mathrm{H}_{2} \mathrm{O}$ & 0.101 \\
$\mathrm{CaCl}_{2}$ & 2.44 \\
$\mathrm{NaBr}$ & 0.474 \\
$\mathrm{Na}_{2} \mathrm{SO}_{4} \cdot 10 \mathrm{H}_{2} \mathrm{O}$ & 11.46 \\
$\mathrm{NaCl}$ & 292.25 \\
\hline
\end{tabular}




\section{CEMENTITIOUS SEAL MATERIALS}

A series of cementitious mixtures has been designed for potential longevity. These mixtures are blends formulated using four gulding principles.

1) A useful material needs to possess intrinsic thermodynamic stability. Lower free energy states and greater stability are caused in portland cements by reducing the amount of the relatively soluble free $\mathrm{Ca}(\mathrm{OH})_{2}$ which remains as a by-product of the hydration of the calcium silicate components. Adding "pozzolans" or silica-rich materials such as blast furnace slag or fly ashes accomplishes this. Thus the nature of pozzolanic reactions is important.

2) Feasible placement must be combined with adequate mechanical and physical properties. High strength is usually associated with durability. Strength increases when the remaining $\mathrm{Ca}(\mathrm{OH})_{2}$ reacts with additional silica to produce more calcium silicate hydrate $(\mathrm{C}-\mathrm{S}-\mathrm{H})$, the strength-producing component in hydrated cement. Reducing the water content of a mix also generates strength, by reducing residual porosity. Strength is inversely related to the amount of water added to the mixture. A conventional cement paste or mortar has a water/cement ratio in the neighborhood of 0.4 to 0.5 . If the amount of water is reduced by effective use of water-reducing agents, the water requirement of a mixture of the same consistency can be reduced to 0.25 to $0.3 \mathrm{~g}$ per $100 \mathrm{~g}$ cement. This results in a substantial increase in strength.

3) The means for transport of water and/or radionuclides through seal materials can be reduced by decreasing the porosity and permeability of the final product. One way that this can be done is by using super water reducers and finegrained pozzolanic materials.

4) Other features relating to stability in a particular bedded salt environment, and kinetics of phase changes are important. The stability of calcium aluminate components of cement, and their effects on the durability of a cement seal material is influential on the materials properties. Formation of ettringite, an AFt phase (aluminate/ferrite tri-substituted) causes the cement to expand. If AFt phases form after the concrete has hardened in an unrestrained state, the material may eventually lose strength through excessive expansion. Controlled expansion of this nature, however, is usually desirable in confined curing, such as in an underground borehole or shaft, whereby a seal which is both chemical and mechanical is produced.

*See Section 3.2 .2 for definition. 
The special properties of expansive phases made it important to study the relationship between AFt phases and AFm phases [aluminate/ferrite, monosubstituted, calcium monochloroaluminate (Friedel's salt), and calcium monosulfoaluminate]. Long-term curing of normal cement compositions converts AFt to AFm phases. This conversion could affect the volume stability of a mixture long after emplacement, and understanding or preventing it by compositional change therefore is important.

Studies of the chemistry of various cementitious mixtures are necessary in considering Iongevity. Long-term studies are under way, but their results are of necessity delayed. The approach we have adopted is dealing with the mechanisms of reaction within the cementitious materials. Important information from theoretical data will be combined with results from short, intermediate and longterm experiments, and those from accelerated tests to determine reaction mechanisms and evaluate kinetic factors. Various pozzolans have been investigated, and many types of reactions appear to have similar mechanisms. The kinetics of these reactions differ, however.

Two major aspects of the chemistry of the hydration process are addressed. These are: the pozzolanic reaction; and the stability of various aluminate phases, especially their bearing on the long-term behavior of a cement plug. Mechanistic studies should in part determine longevity, and will be followed by very longterm experiments with selected cementitious materials. Concurrently, we are investigating the thermodynamics of critical reactions and phase transitions. These studies are an additional source of information with a bearing on longevity.

\subsection{SALT-CONTAINING SEAL MATERIALS AND DERIVATIVE MIXTURES}

\subsubsection{Introduction}

Characterization of a 17-year-old borehole plug (Wakeley et al., 1981b) recovered from bedded evaporites demonstrated that salt-saturated cements were viable plugging materials for salt-dominated strata. Previous work at the Waterways Experiment Station (WES), Sandia (Gulick et al., 1980a), and The Pennsylvania State University (PSU) (Scheetz et al., 1980) on borehole sealing formulations also showed salt-containing cenents to have adequate strength development and generally to be suitable for their intended use. Experimental work at WES led to the development of a formulation known as DHT-1. This was later modified by Dowell and resulted in the basic formulation known as BCT-1F (Gulick et al., 1980b). Although never used in field tests, the mirture (designated PSU 非79-071) was 
included as one of the test formulations in the present study. This mixture led to two derivative formulations BCT-IFF (PSU \#19-091) and PSU "salt-free BCT-IF" (PSU \#79-08). Subsequently, a new intermediate formulation (PSU \#80-081), the so-called PSU/WES mixture, was also investigated. In adition to these formulations, work at PSU also pursued cement formulations containing salt, fly ash, and condensed silica fume (PSU \#81-030 and 81-091).

A11 mixtures were designed to be expansive, and thus contained an expansive agent or additional calcium sulfate which would promote the formation of ettringite and encourage expansion. In theory, expansion would take up any space generated by the dissolution of salt by the plugging formulation and also restress the wall rock and thus prevent annular cracking in the borehole due to stress relief.

\subsubsection{Viscosity}

As a first step in designing and evaluating the suitability of various mixtures, rheologic properties were measured on fresh mixtures (Asaga and Roy, 1980). Shear stress was recorded as a function of shear rate and apparent viscosities were recorded. Results for the final mixtures used are given in Table 3.1.1. The mixtures BCT-1F (79-071), BCT-1FE (79-091), and PSU/WES (80-081) were very fluid, whereas mixtures $81-030$ and 81-091 had higher apparent viscosities. Each mixture was susceptible to shear thinning with time and exhibited near plastic or pseudoplastic behavior. All mixtures exhibited a yield point, although the values for 79-071 and 80-081 were very small, and nearly insignificant.

\subsubsection{Formulations}

Table 3.1 .2 gives the formulations of the six mixtures. The first of these mixtures (79-071) is nearly salt-saturated, containing 29.5g of $\mathrm{NaCl}$ per $100 \mathrm{~g}$ of mixing water. Its formulation and subsequent testing is well documented elsewhere (Gulick et a1., 1980a). The mixtures 79-091, 79-080, and 80-081 (PSU/WES) were derivatives of the original $\mathrm{BCT}-1 \mathrm{~F}$ mixture, in which the salt content was reduced to zero (79-091, and 79-080) or cut to about $14 \mathrm{~g}$ NaCl per $100 \mathrm{~g}$ mixing water (80-081). This latter mixture, its formulation and testing is well documented (Roy et al., 1980; Roy et a1., 1981). For the sake of brevity, the reader is again referred to these outside sources, for more complete data.

The PSU salt-free "BCT-1FF" samples (79-080) were mixed according to API 
Table 3.1.1. Apparent viscosity $(\mathrm{cP})^{+}$measured at $117 \mathrm{sec}^{-1}$ shear of salt and salt derivative mixtures.

\begin{tabular}{|c|c|c|c|c|c|c|}
\hline \multirow{2}{*}{ mixture } & \multicolumn{6}{|c|}{ time, hrs } \\
\hline & 0.11 & 0.5 & 1.0 & 2.0 & 2.5 & 5.0 \\
\hline $79-071$ & 180 & 300 & 460 & -- & 665 & 1215 \\
\hline $79-091$ & 106 & 273 & 637 & 1042 & $-\infty$ & $-\infty$ \\
\hline $79-080$ & $-\infty$ & $-\infty$ & $-\infty$ & -.- & $-\infty$ & $-\infty$ \\
\hline $80-081$ & 158 & 203 & 206 & 322 & $-\infty$ & $-\infty$ \\
\hline$* 81-030$ & 765 & 1000 & 1331 & -- & -- & --- \\
\hline *81-091 & 599 & 843 & 1108 & $-m-$ & $-\infty$ & $-\infty$ \\
\hline
\end{tabular}


Table 3.1.2. Formulations of salt-containing and derivative mixtures (grams).

mixture

\begin{tabular}{|c|c|c|c|c|c|c|c|}
\hline & \multirow{2}{*}{ Code No.* } & \\
\hline & & $\begin{array}{l}79-071 \\
\text { BCT-1F }\end{array}$ & $\begin{array}{r}79-091 \\
\text { BCT-1FF }\end{array}$ & $\begin{array}{c}\quad 79-080 \\
\text { PSU salt free }\end{array}$ & $\begin{array}{r}80-081 \\
\text { PSU/WES }\end{array}$ & $81-030$ & $81-091$ \\
\hline class $H$ cement & $\mathrm{H}-7, \mathrm{H}-8$ & 62.42 & 67.95 & 67.95 & 65.83 & 65.75 & 65.80 \\
\hline Litepoz & $\mathrm{B} 15, \mathrm{~B} 26$ & 21.09 & 22.96 & 22.95 & 22.17 & - & - \\
\hline gypsea1 & A 31 & - & - & - & 8.07 & 4.04 & 4.04 \\
\hline low line fly ash & B25 & - & -- & - & - & 11.12 & 11.10 \\
\hline ferrosilicon dust & B31 & - & -- & -- & -- & 15.16 & -- \\
\hline Ohio fume & B27 & -- & -- & -- & -- & -- & 15.14 \\
\hline C109 sand & $\mathrm{C} 15$ & -- & -- & - & -- & 49.31 & 49.24 \\
\hline $\mathrm{NaC1}$ & B8, B16 & 8.14 & -- & -- & 3.92 & 3.93 & 3.92 \\
\hline expansive additive $A$ & A29 & 8.35 & 9.09 & 9.10 & -- & -- & - \\
\hline $\mathrm{D}-65$ & A28 & 0.25 & 0.27 & 0.22 & 1.06 & -- & 1.0 \\
\hline$D-47$ & A27 & 0.02 & -- & 0.02 & 0.02 & -- & -- \\
\hline Mighty 150 & A. $3, A 36$ & -- & -- & -- & -- & 1.36 & -- \\
\hline water & E01, E11 & 27.56 & 25.07 & 24.75 & 28.46 & 29.89 & 30.00 \\
\hline$w / c$ & & 0.44 & 0.37 & 0.36 & 0.43 & 0.45 & 0.46 \\
\hline w/reactive solid & & 0.27 & 0.25 & 0.25 & 0.28 & 0.30 & 0.30 \\
\hline
\end{tabular}

HMltiple listings signify different batches of the same material. Differences in properties are small to insignificant. Compositions are given in Appendix A. 
procedures, molded in glass vials and cured at temperature. The samples were broken free from the vials at 24 hours and curing continued in WIPP-A brine.* The BCT-IFF formulation was used in permeability and bond strength experiments and not tested for compressive strength, etc., as was the case for all other mixtures. It too was mixed according to API procedures.

Mixtures 81-030 and 80-091 included different pozzolanic materials and the amounts of salt and expansive additive were proportionally smaller than in previous mixtures. Also, these later mixtures contained ASTM C 109 sand and thus had the properties of dense grouts or mortars. Compositions of the starting materials are given in Appendix A.

Samples were cast as either $25.4-\mathrm{mm}$ by $50.8-\mathrm{mm}$ long cylinders or $50.8-\mathrm{mm}$ cubes, cured at temperature, demolded at 24 hours and allowed to cure in saturated $\mathrm{Ca}(\mathrm{OH})_{2}$ solution, saturated $\mathrm{Ca}(\mathrm{OH})_{2}$ plus $\mathrm{NaCl}$ solution, or brine solution until the time of test. In addition, sample 81-091 was also cast in Tefloncoated glass vials which were cured in saturated relative humidity at specified temperatures. These were partially restrained low-water-content samples, used for microhardness and permeability determinations.

\section{1 .4 Results}

Compressive Strength. Strength data are given in Table 3.1.3. The BCT-1F mixture (79-071) was cured at three temperatures $\left(27^{\circ}, 60^{\circ}\right.$, and $\left.90^{\circ} \mathrm{C}\right)$ as a function of time up to 180 days. These samples were cast as cylinders, nominally 25.4-mm by 50.8-mm 1ong. Since the mixture was nearly saturated with salt, it was subsequently cured in a saturated NaCl brine solution also saturated with $\mathrm{Ca}(\mathrm{OH})_{2}$. Mixture (80-081) was cast as 50.8-mm cubes and cured in saturated $\mathrm{Ca}(\mathrm{OH})_{2}$ solution at one temperature $\left(38^{\circ} \mathrm{C}\right)$.

The development of strength for the PSU/WES mixture (80-081) was nearly linear up to 56 days, after which time unrestrained expansion of the cubes caused the samples to weaken and strengthen in a cyclic pattern up to 365 days. The strength development for the BCT-1F cylinders was linear (based on only two points), but only up to 28 days, after which the same pattern of weakening and regain of strength is repeated. The rates of strength development of the two mixtures are similar, but setting of $\mathrm{BCT}-1 \mathrm{~F}(79-071)$ was retarded.

*WIPP-A brine (PSU \#E07): 11.14 wt \% $\mathrm{MgCl}_{2}, 8.98$ wt $\% \mathrm{NaCl}, 4.77$ wt \% $\mathrm{KCl}$, 0.36 wt $\% \mathrm{MgSO}_{4}, 0.14$ wt $\% \mathrm{CaCl}_{2}$. 
Table 3.1.3. Compressive strength of salt-containing and derivative mixtures (MPa).

\begin{tabular}{|c|c|c|c|c|c|c|c|}
\hline \multirow{2}{*}{$\begin{array}{c}\text { specimen } \\
\text { age } \\
\text { (days) }\end{array}$} & \multirow{2}{*}{$\begin{array}{l}\text { cure } \\
\text { temp. } \\
\left({ }^{\circ} \mathrm{C}\right)\end{array}$} & \multicolumn{6}{|c|}{ mixture } \\
\hline & & $79-071$ & $79-091 \% *$ & $79-080$ & $80-081$ & $81-030$ & $81-091$ \\
\hline 3 & $\begin{array}{l}27 \\
35 \\
38 \\
45 \\
60 \\
90\end{array}$ & & & & 50.5 & & $\begin{array}{l}49.3 \\
63.7 \\
79.1 \\
76.1\end{array}$ \\
\hline 7 & $\begin{array}{l}27 \\
35 \\
38 \\
45 \\
60 \\
90\end{array}$ & & & $\begin{array}{l}70.8 \\
85.0 \\
90.6 \\
51.6\end{array}$ & 65.2 & $\begin{array}{l}37.3 \\
61.5 \\
64.9 \\
58.2\end{array}$ & $\begin{array}{l}53.4 \\
77.5 \\
76.9 \\
61.9\end{array}$ \\
\hline 14 & $\begin{array}{l}27 \\
35 \\
38 \\
45 \\
60 \\
90\end{array}$ & $\begin{array}{l}49.4 \\
61.4 \\
45.9\end{array}$ & & $\begin{array}{r}57.2 \\
121.0 \\
72.6 \\
43.4\end{array}$ & & $\begin{array}{l}41.8 \\
66.2 \\
60.6 \\
46.8\end{array}$ & \\
\hline 28 & $\begin{array}{l}27 \\
35 \\
38 \\
45 \\
60 \\
90\end{array}$ & $\begin{array}{l}63.4 \\
65.5 \\
60.2\end{array}$ & & $\begin{array}{r}87.0 \\
110.6 \\
102.2 \\
52.3\end{array}$ & 91.7 & $\begin{array}{l}79.3 \\
85.6 \\
88.2 \\
96.9\end{array}$ & $\begin{array}{l}77.8 \\
91.1 \\
80.0 \\
83.1\end{array}$ \\
\hline 56 & $\begin{array}{l}27 \\
35 \\
38 \\
45 \\
60 \\
90\end{array}$ & $\begin{array}{l}57.21 \\
48.3 \\
35.8\end{array}$ & & $\begin{array}{r}85.9 \\
118.8 \\
123.7 \\
54.4\end{array}$ & 107.7 & & $\begin{array}{l}64.6 \\
74.9 \\
61.4 \\
84.7\end{array}$ \\
\hline 90 & $\begin{array}{l}27 \\
35 \\
38 \\
45 \\
60 \\
90\end{array}$ & $\begin{array}{l}68.0 \\
68.7\end{array}$ & & $\begin{array}{r}122.1 \\
81.2\end{array}$ & 61.5 & & $\left.\begin{array}{l}23.8 \\
28.3 \\
26.2 \\
27.0\end{array}\right\}$ \\
\hline 180 & $\begin{array}{l}27 \\
35 \\
38 \\
45 \\
60 \\
90\end{array}$ & $\begin{array}{l}78.5 \\
61.1\end{array}$ & & & 93.2 & & $\begin{array}{l}76.1 \\
86.3 \\
76.8\end{array}$ \\
\hline 365 & 38 & & & & 83.2 & & \\
\hline
\end{tabular}

*Data set believed incorrectly recorded scale on chart. HeNo data. 
The compressive strength data for mixture 79-080 (PSU salt-free) also show relative consistency in the strength increases in the temperature range $27^{\circ}-60^{\circ} \mathrm{C}$, with generally lower strengths of samples cured at $90^{\circ} \mathrm{C}$. These saltfree samples when cured in WIPP-A brine after demolding at 24 hours would permit some diffusion of chlorides, in particular, into the samples.

Compressive strength development of mixtures 81-030 and 81-091 is very similar to the development of strength by 79-071, 80-081 and 79-080. However, the 81-030 and 81-091 samples cured at $90^{\circ} \mathrm{C}$ have consistently higher relative strengths than the mixtures in sets 79-071, 80-081 and 79-080.

Microhardness. Data for the above mixtures are given in Appendix B. These values are not directly proportional to strength, but samples having low strength have low microhardnesses.

Bulk Density. These measured values for all mixtures are given in Table 3.1.4. The slight decrease in bulk density of the BCT-1F mixture (79-071) with time may reflect the expansion of the sample. Changes in bulk density of the PSU/WES mixture (80-081), follow a pattern similar to compressive strength and apparently are related to the expansive mechanism. The data for mixture 81-091 except for one or two anomalies remain relatively high. The data for mixture 81-030 are relatively constant to 28 days, the last time measured.

Permeability. Limited data are available for permeability of mixtures 79-071, 79-091 and 79-080. Data for confined curing are included in section 3.5 on composite studies.

Permeabilities of the PSU/WES mixture (80-081) to water are given in Table 3.1.5. Data for three types of samples are presented. The permeabilities for the unrestrained samples cured at $38^{\circ} \mathrm{C}$ in $\mathrm{Ca}(\mathrm{OH})_{2}$ solution show greater variability in flow than do the restrained (steel ring and sealed vial cured) counterparts. Apparently this is related to the expansion of the sample, which is unrestrained in one case, and partially restrained in the others (steel ring, lesser restraint, sealed glass vial). Since down-hole conditions are more nearly represented by the restrained condition and the presence or absence of excess water does not appear to be of concern, assuming no interface difficulties, this would suggest that expected permeabilities should be in the range of $<10^{-8} \mu^{2}\left(<10^{-11} \mathrm{~cm} \mathrm{sec}^{-1}\right.$ equivalent hydraulic conductivity or $10^{-8}$ darcy $)$. 
Table 3.1.4. Bulk density of salt-containing and derivative mixtures.

\begin{tabular}{|c|c|c|c|c|c|c|c|}
\hline \multirow{2}{*}{$\begin{array}{c}\text { specimen } \\
\text { age } \\
\text { (days) }\end{array}$} & \multirow{2}{*}{$\begin{array}{l}\text { cure } \\
\text { temp. } \\
\left({ }^{\circ} \mathrm{C}\right)\end{array}$} & \multicolumn{6}{|c|}{ mixture } \\
\hline & & $79-071$ & $79-091 * *$ & $79-080$ & $80-081^{*}$ & $81-030$ & $81-091$ \\
\hline 3 & $\begin{array}{l}27 \\
35 \\
38 \\
45 \\
60 \\
90\end{array}$ & & & & 0.006 & & $\begin{array}{l}1.92 \\
1.93 \\
1.90 \\
1.92\end{array}$ \\
\hline 7 & $\begin{array}{l}27 \\
35 \\
38 \\
45 \\
60 \\
90\end{array}$ & & & $\begin{array}{l}2.15 \\
2.23 \\
2.54 \\
2.11\end{array}$ & 0.004 & $\begin{array}{l}1.85 \\
1.85 \\
1.87 \\
1.86\end{array}$ & $\begin{array}{l}1.90 \\
1.92 \\
1.89 \\
1.91\end{array}$ \\
\hline 14 & $\begin{array}{l}27 \\
35 \\
38 \\
45 \\
60 \\
90\end{array}$ & $\begin{array}{l}2.09 \\
2.10\end{array}$ & & $\begin{array}{l}2.09 \\
2.28 \\
2.09 \\
2.08\end{array}$ & & $\begin{array}{l}1.83 \\
1.87 \\
1.85 \\
1.85\end{array}$ & \\
\hline 28 & $\begin{array}{l}27 \\
35 \\
38 \\
45 \\
60 \\
90\end{array}$ & $\begin{array}{l}2.07 \\
2.11 \\
2.11\end{array}$ & & $\begin{array}{l}2.19 \\
2.20 \\
2.20 \\
2.21\end{array}$ & 0.016 & $\begin{array}{l}1.84 \\
1.86 \\
1.85 \\
1.84\end{array}$ & $\begin{array}{l}1.94 \\
1.92 \\
2.24 \\
1.93\end{array}$ \\
\hline 56 & $\begin{array}{l}27 \\
35 \\
38 \\
45 \\
60 \\
90\end{array}$ & $\begin{array}{l}2.15 \\
2.07\end{array}$ & & $\begin{array}{l}2.12 \\
2.06 \\
2.14 \\
2.06\end{array}$ & 0.028 & & $\begin{array}{l}1.83 \\
1.83 \\
1.50 \\
2.11\end{array}$ \\
\hline 90 & $\begin{array}{l}27 \\
35 \\
38 \\
45 \\
60 \\
90\end{array}$ & $\begin{array}{l}2.06 \\
2.03\end{array}$ & & $\begin{array}{l}2.12 \\
2.15 \\
2.11 \\
1.98\end{array}$ & 0.018 & & $\begin{array}{l}1.83 \\
1.95 \\
1.84 \\
1.84\end{array}$ \\
\hline 180 & $\begin{array}{l}27 \\
35 \\
38 \\
45 \\
60 \\
90\end{array}$ & $\begin{array}{l}1.97 \\
2.00\end{array}$ & & & 0.006 & & $\begin{array}{l}1.91 \\
1.90 \\
1.94 \\
1.97\end{array}$ \\
\hline 365 & 38 & & & & 0.005 & & \\
\hline
\end{tabular}

*Change in density.

* No data. 
Table 3.1.5. Permeability to water of 80-081 expansive cement cured at $38^{\circ} \mathrm{C}$ (darcys, $\mu \mathrm{m}^{2}$ ).

\begin{tabular}{|c|c|c|c|}
\hline \multirow{2}{*}{$\begin{array}{l}\text { cure } \\
\text { time } \\
\text { (days) }\end{array}$} & unrestrained & \multicolumn{2}{|c|}{ restrained } \\
\hline & $\begin{array}{c}\mathrm{Ca}(\mathrm{OH})_{2} \text { solution } \\
\text { cure }\end{array}$ & $\begin{array}{c}50.8 \mathrm{~mm} \\
\text { cast in steel } \\
\text { rings }\end{array}$ & $\begin{array}{l}\text { glass } \\
\text { vial } \\
\text { cure }\end{array}$ \\
\hline 3 & \multirow{3}{*}{$<10^{-8}$} & \multirow{6}{*}{$<10^{-8}$} & \multirow{6}{*}{$<10^{-8}$} \\
\hline 7 & & & \\
\hline 28 & & & \\
\hline 56 & $9.7 \times 10^{-5}$ & & \\
\hline $\begin{array}{r}90 \\
180\end{array}$ & $<10^{-8}$ & & \\
\hline 365 & $1.8 \times 10^{-6} *$ & & \\
\hline
\end{tabular}

* Sample had an observable pre-existing crack when tested. 
Permeabilities of mixtures $81-030$ and $81-091$ to water are given in Table 3.1.6. Although the samples 81-030 and 81-091 differ only slightly in composition, the permeability data do not attest to this fact. The 81-030 mixture cured in $\mathrm{Ca}(\mathrm{OH})_{2}$ solution and the 81-091 glass vial cured samples shows very low permeabilities at nearly all times and temperatures. Some anomalies in test procedures used with $81-091$ cured in $\mathrm{Ca}(\mathrm{OH})_{2}$ solution prevent complete interpretation of the latter data. The permeabilities of all the samples were very low at 180 days.

X-Ray Diffraction Data. Data for mixtures 79-071 (BCT-1F) and 80-081 (PSU/WES) are given in Table 3.1.7. Apparent1y, the phases which are developed are related to the concentration of salt in the mixture, curing temperature, and curing environment. In nearly salt-saturated $\mathrm{BCT}-1 \mathrm{~F}$ [cured in $\mathrm{Ca}(\mathrm{OH})_{2}+\mathrm{NaCl}$ ] the dominant aluminate phase at $90^{\circ} \mathrm{C}$ is Friedel's salt $\left[\mathrm{Ca}_{3} \mathrm{Al}_{2} \mathrm{O}_{6} \cdot \mathrm{CaCl}_{2} \cdot 10 \mathrm{H}_{2} \mathrm{O}\right.$, as might be expected. However, at $27^{\circ} \mathrm{C}$ ettringite and Friedel's salt coexist at 28 to 56 days, while ettringite is abundant at 90 to 180 days. In the PSU/WES (80-081) mixture, those unrestrained samples cured at $38^{\circ} \mathrm{C}$ in saturated $\mathrm{Ca}(\mathrm{OH})_{2}$ solution contained ettringite at all times up to one year, the chloride possibly leached out. In contrast, those samples cured in glass vials in a saturated humidity environment, first developed ettringite, then at 28 days to one year, also contained coexisting Friedel's salt. Apparently the substantial chlorine activity, the lack of $\mathrm{Ca}(\mathrm{OH})$, and abundant water moderated etringite $\left(\mathrm{Ca}_{3} \mathrm{Al}_{2} \mathrm{O}_{6} \cdot 3 \mathrm{CaSO}_{4} \cdot 32 \mathrm{H}_{2} \mathrm{O}\right)$ formation.

$\mathrm{X}$-ray diffraction data for mixture 79-080 (PSU salt/free/"BCT-1FF") are given in Table 3.1.8. The brine curing solution has interacted with the sample and changed its phase chemistry. Some liberty has been taken with the data in order to reduce it to the simple terms shown in the table. Basically, the $\mathrm{MgCl}_{2}$ in the solution must have diffused into the sample and produced $\mathrm{Mg}(\mathrm{OH})_{2}$ and $\mathrm{CaCl}_{2}$, the latter reacting to produce Friedel's salt. In addition, the chloride activity of the cement was also elevated by the NaCl present in the brine. This high activity is instrumental in changing the ettringite to Friedel's salt. Although not always present, $\mathrm{Mg}(\mathrm{OH})_{2}$ apparently formed in preference to $\mathrm{Ca}(\mathrm{OH})_{2}$. A problem which made interpretation more difficult was the depth of penetration of the solution, the resulting degree of conversion and the random sampling of the compressive strength samples subsequently used 
Table 3.1.6. Water permeability of mixtures $81-030$ and $81-091$ as a function of temperature and curing conditions (darcys $\cong \mu \mathrm{m}^{2}$ ).

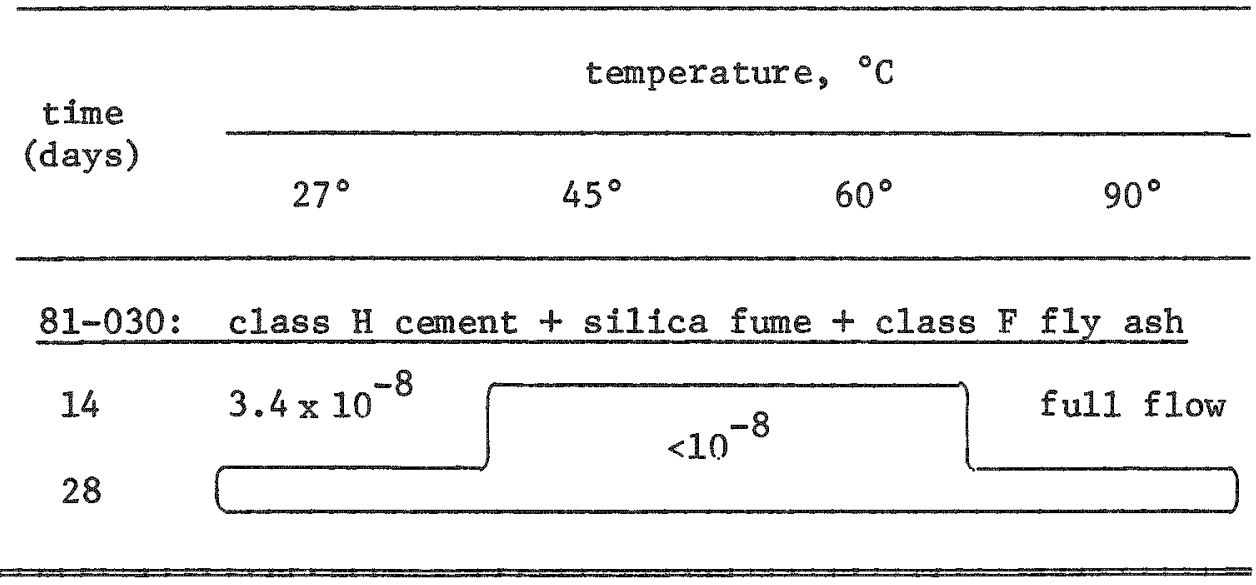

81-091: class H cement + silica fume + class F fly ash
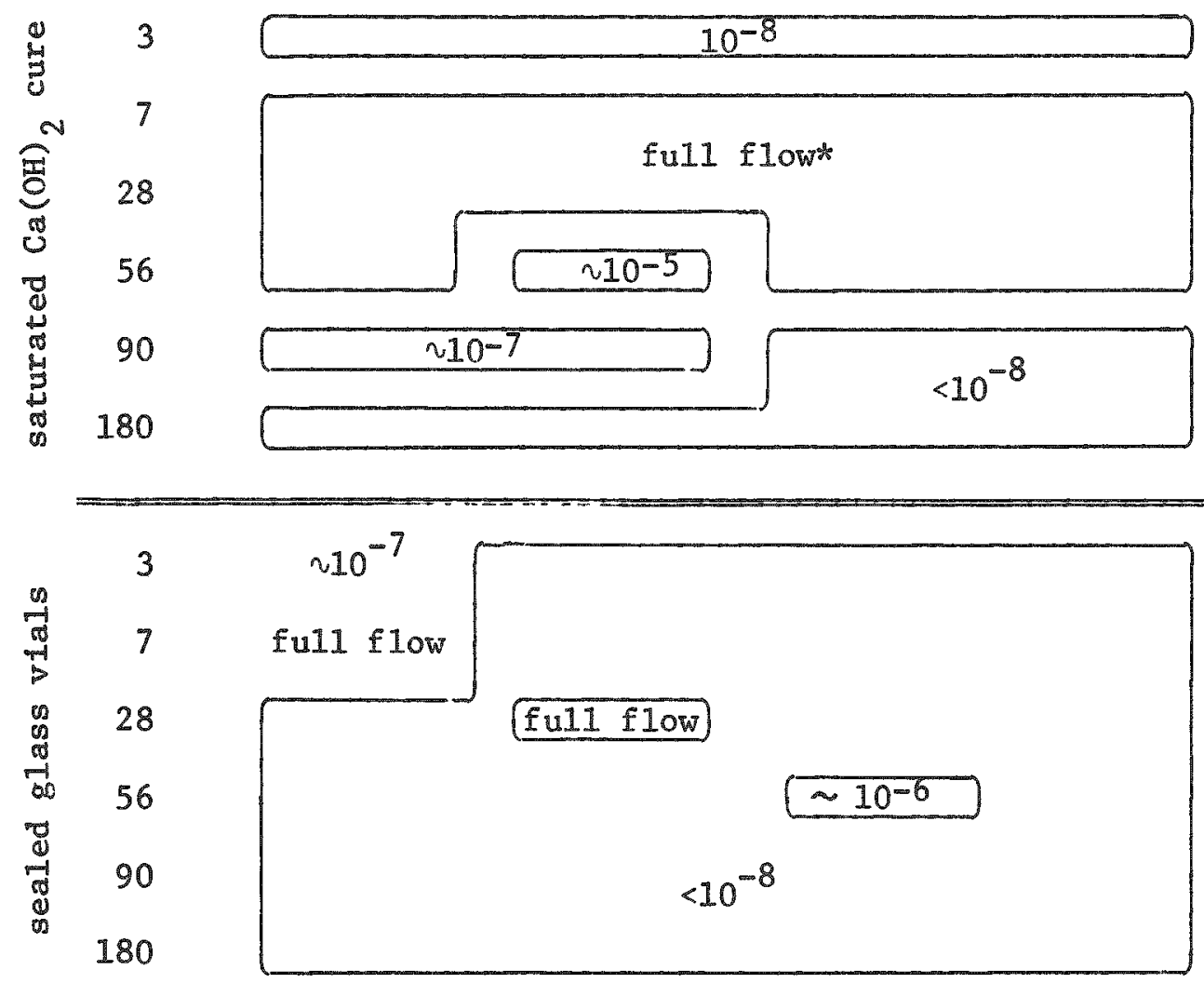

$\Longrightarrow$

*Excessive pressures (1000 psi) may have broken the samples. Repeat testing of different samples at 650 to 680 psi at 7. 28 , and 56 days resulted in no flow which is equivalent to a permeabllity of $<10^{-8}$ darcy. Apparently the vial-cured samples were less prone to cracking due to the suppression of expansive character by the lack of excess water. 
Table 3.1.7. X-ray diffraction data for expansive cement pastes containing varying amounts of salt.

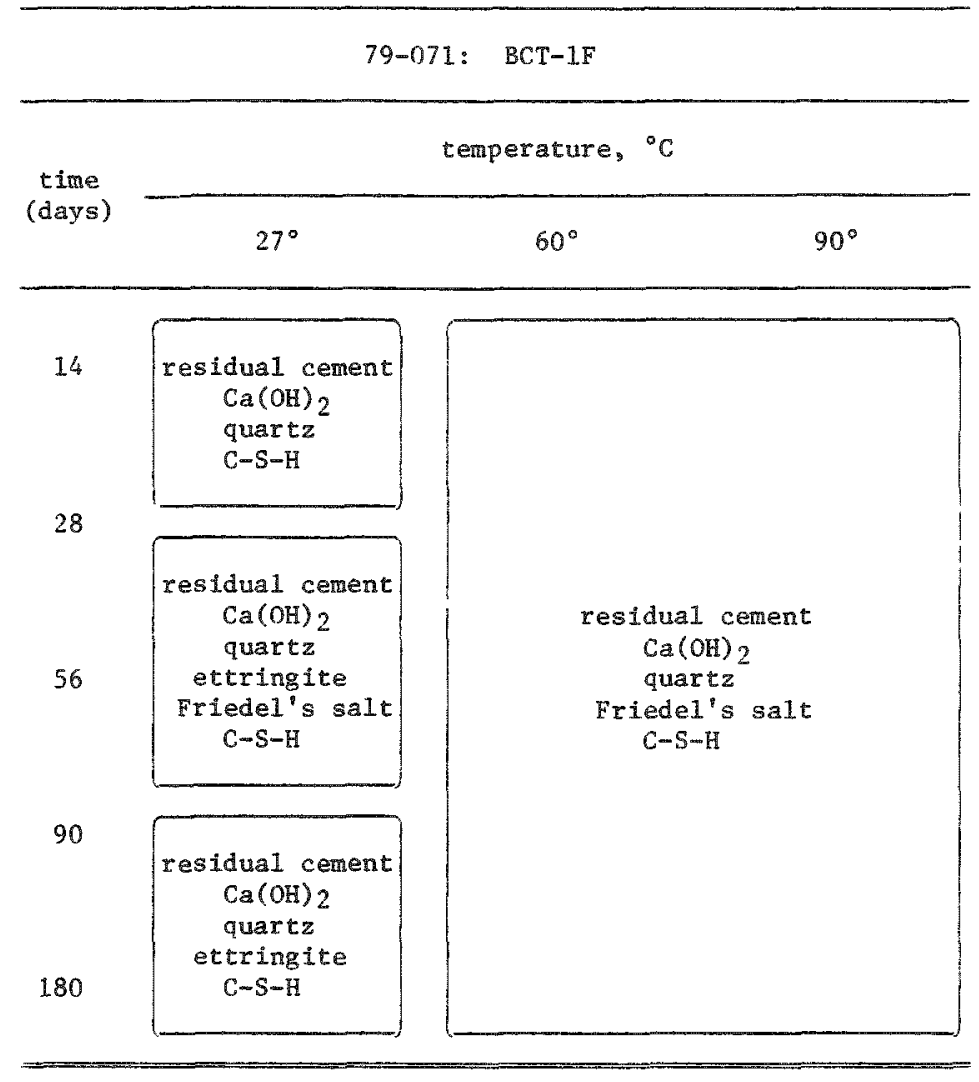

80-081: PSU/WES

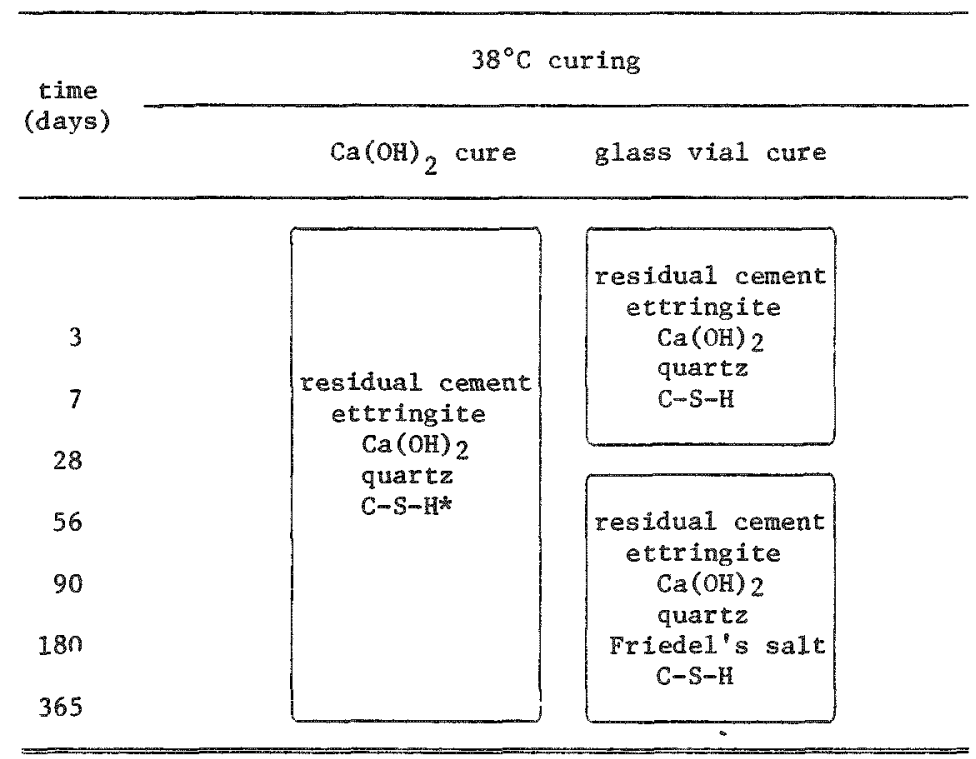

$* \mathrm{CaCO}_{3}$ sometimes detected in all of these samples.

Apparenty these are extremely susceptible to carbonation. 
Table 3.1.8. X-ray diffraction data for derivative mixtures.

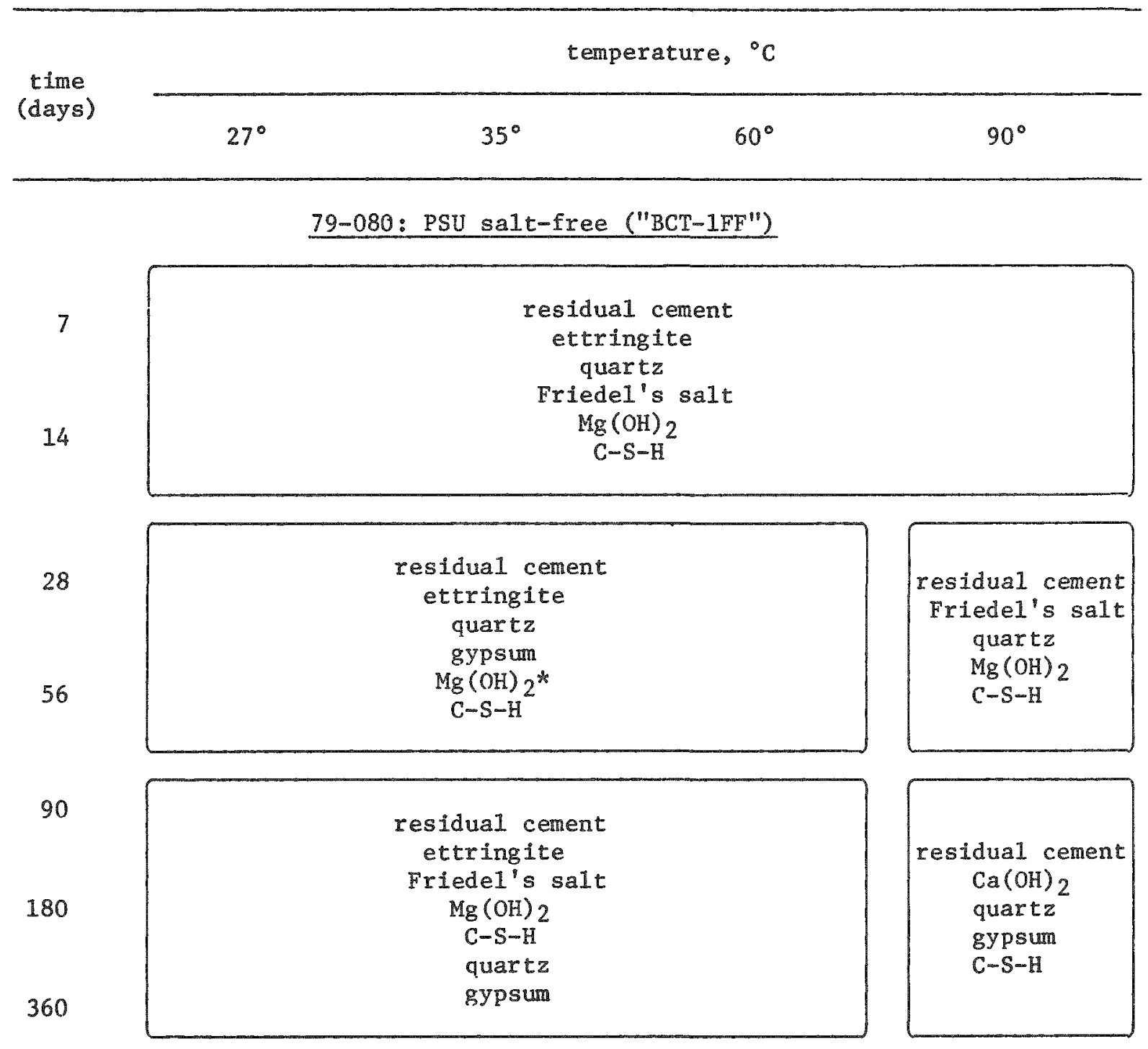

*The $\mathrm{Mg}(\mathrm{OH})_{2}$ apparently forms in the following fashion: $\mathrm{Ca}(\mathrm{OH})_{2}+\mathrm{MgCl}_{2} \rightarrow$ $\mathrm{Mg}(\mathrm{OH})_{2}+\mathrm{CaCl}_{2}$ Iiberating the $\mathrm{CaCl}_{2}$ to take part in forming Friedel's salt $\left(\mathrm{C}_{3} \mathrm{~A} \cdot \mathrm{CaCl}_{2} \cdot 12 \mathrm{H}_{2} \mathrm{O}\right)$ or $\mathrm{AFt}$-substituted phases. 
for $x$-ray diffraction work. The results, however, illustrate the influence of the curing solution (and hence, host rock chemistry) on the results of various tests and on the potential long-term behavior of the seal once emplaced in a geologic formation.

$\mathrm{X}$-ray diffraction data for samples 81-030 and 81-091 [cured in sat. $\mathrm{Ca}(\mathrm{OH})_{2}$ ] are presented in Table 3.1.9. Ettringite apparently forms at lower temperatures in these mixtures, but above $60^{\circ} \mathrm{C}$, at least in mixture $81-091$, some sulfate is present as gypsum which, with time, seems to disappear altogether. Both the gypsum (which is secondary in nature, formed from CaSO $4{ }^{\circ} 1 / 2-\mathrm{H}_{2} \mathrm{O}$ and the ettringite are potentially expansive. Mixtures 79-091 data (BCT-1FF) are not available. Only bond strength and permeability were determined for this material.

SEM Investigation. In an attempt to better interpret the mechanical and phase data, a series of scanning electron microscope images were taken for mixture 80-081 (PSU/WES). Representative images are presented in Figures 3.1 .1 and 3.1.2 for 7 - and 90-day vial-cured samples, respectively.

Prisms or needles of ettringite were most commonly observed having grown in pockets or void spaces in the cured grout samples (Figure 3.1.1B). These were most easily located in the youngest sample and were clearly evident at 3 , 7 , and 28 days. At ages beyond 56 days, with increasing completeness of hydration, these occurrences became scarcer, although some prisms could be found (see, for example, Figure 3.1.2--90-day results). Some ettringite-1ike material is observed at 180 days, but its habit is more massive. This latter massive material may be the more common form of etringite. It is more difficult to recognize, but may be responsible for the abundance of ettringite in the s-ray diffraction pattern.

Fly ash spheres in various states of alteration were observed throughout the 365-day curing of the paste and are described in Roy et al. (1981) and Grutzeck et al. (1981b).

Densification of the paste seems to occur with time. Pockets of ettringite are being filled or replaced by other material. Fly ash spheres are hydrating and becoming part of the matrix material. In broken samples the fly ash spheres act as centers of weakness and therefore are involved in the breaking process, the glass-to-hydration product rims being a weak link in the younger pastes. In older pastes the fly ash spheres are hydrated and incorporated into the matrix, becoming less involved with the breaking process. In specimens cut with a diamond saw the void features which are so common in 
Figure 3.1.1. SEM images of 7 -day cured $60^{\circ} \mathrm{C}$ vacuum-dried shell-vial samples of mixture 80-081.
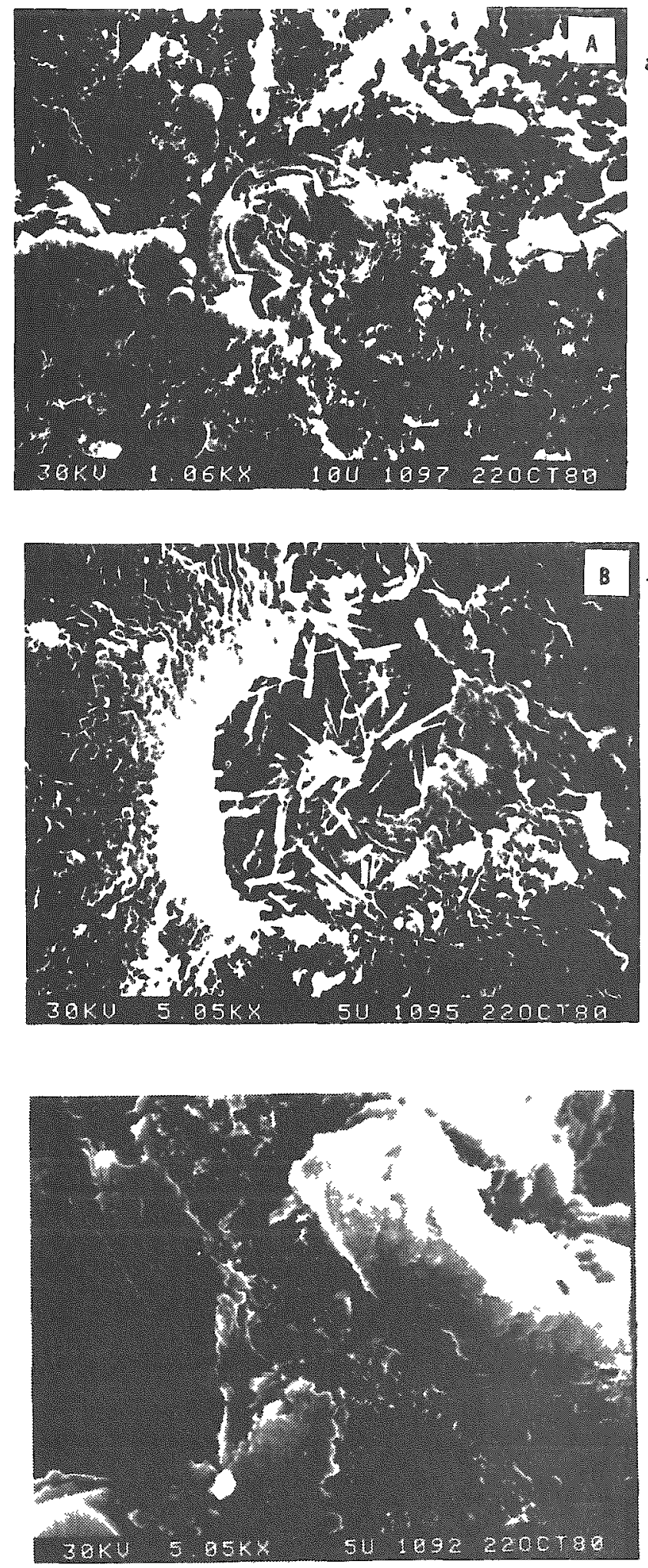

a) Overal1 view of typical surface at $1060 \mathrm{x}$ showing fly ash spheres, fly ash voids and dense matrix. A collapsed fly ash shell with internal crystallites is visible.

b) Ettringite detail in two hexagonal gypsum casts and dense matrix material. These features may be precurers of Hadley grains (5050X).

c) Ettringite growing in a void space surrounded by $\mathrm{C}-\mathrm{S}-\mathrm{H}$ type matrix material (5050x). 
Figure 3.1.2. SEM images of 90-day "as-cured" shel1-vial cured samples of mxiture 80-081.

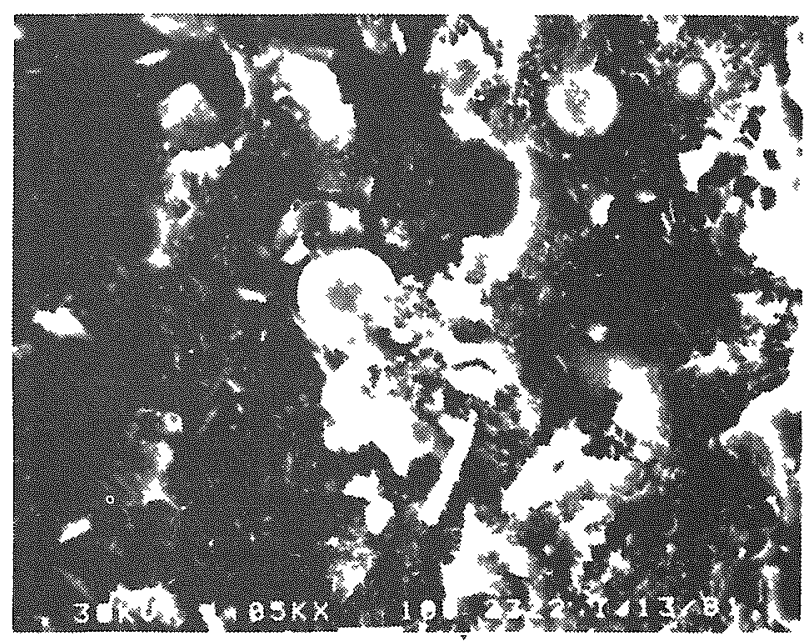

a) Overall view of typical surface at 1050X showing fly ash spheres and voids in various states of hydration. Some ettringite in pockets and massive matrix is also evident.

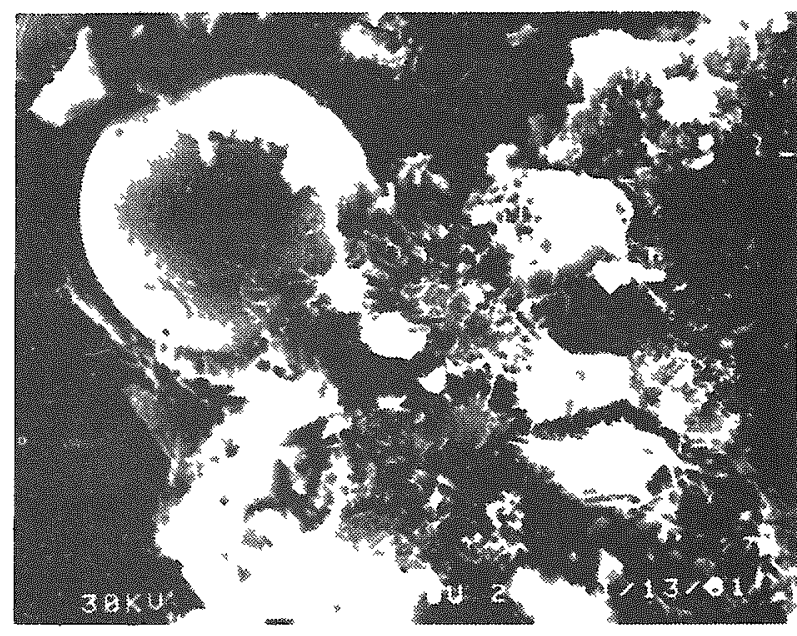

b) Detail of fly ash and ettringite $(3070 \mathrm{x})$.

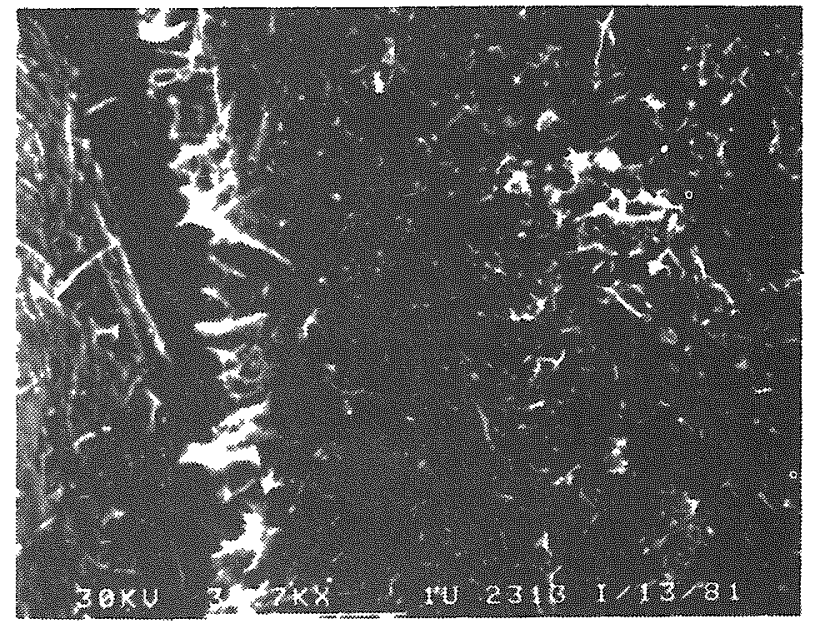

c) Detail of fly ash/matrix contact. Fly ash sphere surface is on left. Bladelike crystals in center of photograph are typical hydration products of the glassy fly ash sphere $(30700 \mathrm{x})$. 
Table 3.1.9. X-ray diffraction data for silica and class F fly ash-substituted cements.

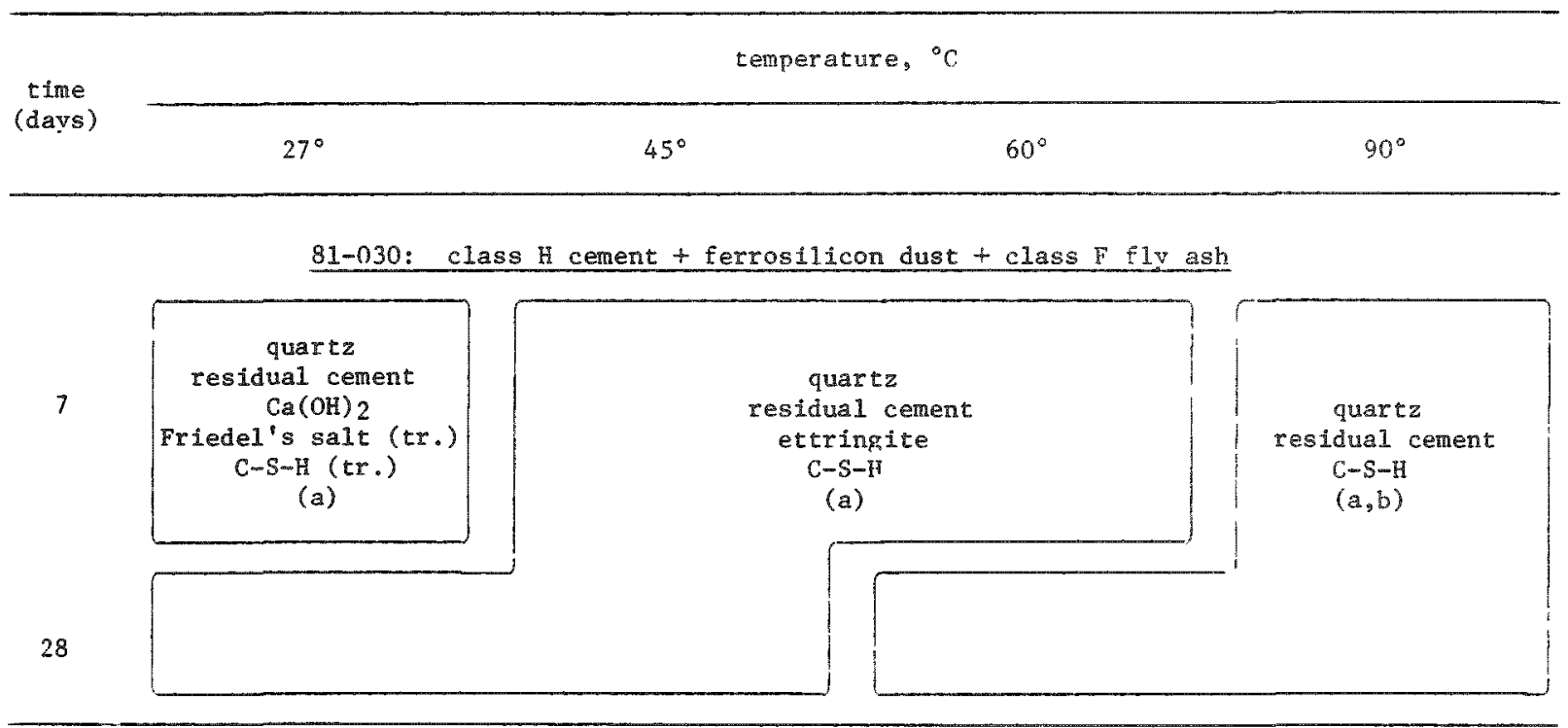

(a) traces of aluminate hydrates and/or gehlenite hydrate

(b) trace amounts of anhwdrite sometimes present

81-091: Class H cement + ferrosilicon dust + class F fly ash

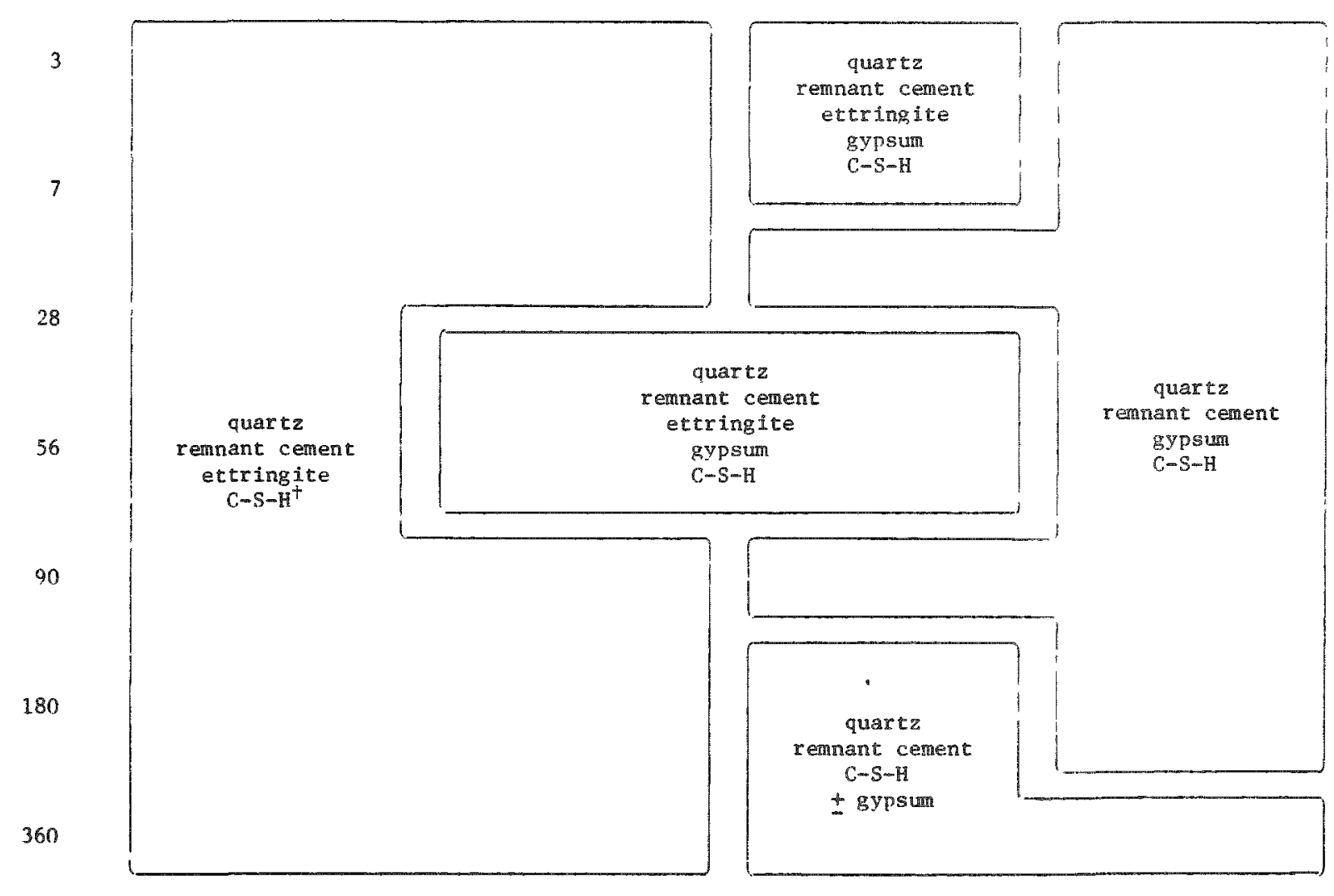

${ }^{\dagger}$ a duplicate sample at $38^{\circ} \mathrm{C}$ hydrated for 7 days showed slight evidence of gypswar. 
broken samples are generally lacking. Cross sections of fly ash spheres show hydration in various stages, and the hydration rim is continuous from the glass surface to the matrix. There is very little evidence to indicate a gap of any kind between glass spheres and hydration rim. The matrix is very dense and the actual void features attributed to the presence of $f l y$ ash spheres are few.

A similar SEM study was made for mixture 81-091 (Grutzeck et al., 1981b). Representative SEM images are presented in Figure 3.1.3. Views (a) and (b) show a generally dense matrix, presumably due to the silica fume and partially reacted fly ash spheres typical of 3 days. By 28 days (view c) the fly ash is significantly reacted. Bonding to the matrix is stronger and features, showing breakage of the fly ash in cross section, are more common. At 90 days ( $v$ iew d) the matrix is still very dense and $f 1 y$ ash spheres are more highly reacted. Views (e) and (f) at 180 days re-emphasize that some fly ash spheres are fully reacted ( $v$ iew e) while others are still in the process of reaction. In both cases at 180 days bonding of the fly ash to the matrix is very good (view $f$ ), which correlates we11 with the low permeabilities measured.

Other Tests. Early volume change measurements (Setter and Roy, 1978; Perez, 1981) to 24 hours were made using the BCT-1F formulation, with and without salt. Typical results of these measurements are shown in Figure 3.1.4, which shows for contrast, measurements made on the pure Incor " $H$ " cement paste. The reduced shrinkage during the early stages for the sample containing salt, is consistent with previous findings. Similar data are given for mixture 81-091 in Figure 3.1.5. Volumetric data are compared to longitudinal change. The percent unidimensional change approaches a constant value of minus $0.08 \%$. The volumetric change is approximately ten times as big.

Dynamic Young's modulus data for bars of mixture 81-091 cured in saturated $\mathrm{Ca}(\mathrm{OH})_{2}$ solution are given in Figure 3.1.6. Data for bars cured at $27^{\circ}, 38^{\circ}$, and $60^{\circ} \mathrm{C}$ are given. There is a general increase in modulus with time up to 180 days curing for each temperature. The drop in modulus values at $60^{\circ} \mathrm{C}$ beyond 80 days is attributed to the expansive character of the paste.

Therma1 conductivity measurements on mixture 81-091 as a function of time and temperature were also completed. These data are presented in Table 3.1.10. At a given temperature, most values increase with time, reflecting a "normal" progression of hydration. As pore space previously occupied by gas or water becomes bridged or filled by the developing hydration products, the thermal conductivity tends to increase. 
F'igure 3.1.3. SEM images of mixture 81-091 cured at $60^{\circ} \mathrm{C}$.

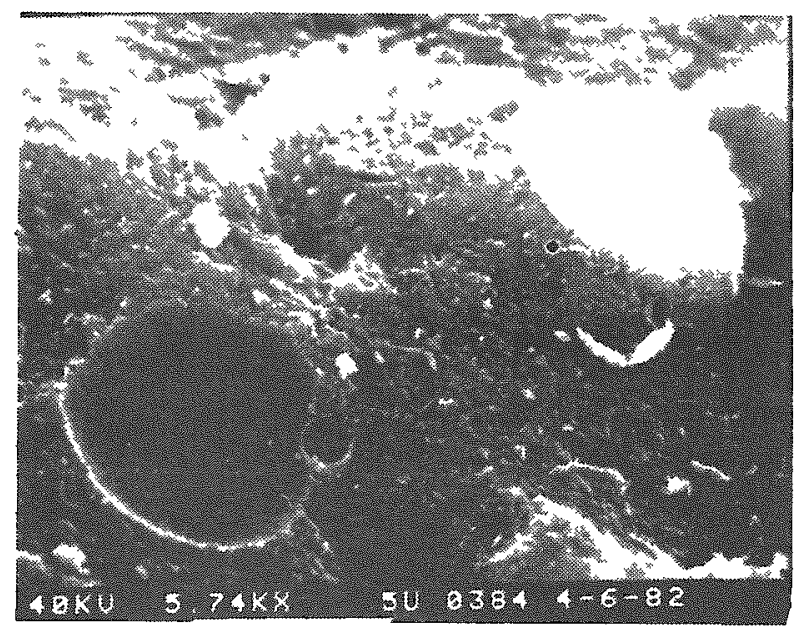

(a)

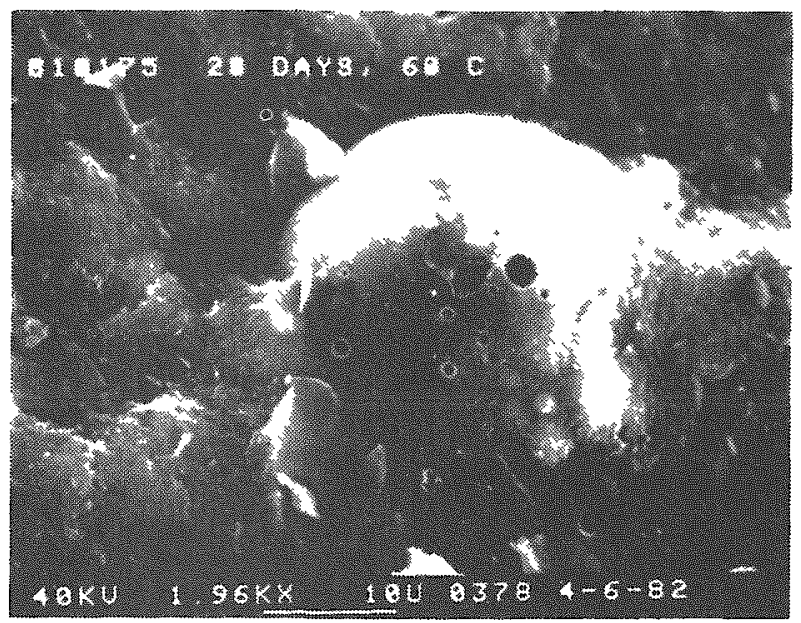

(c)

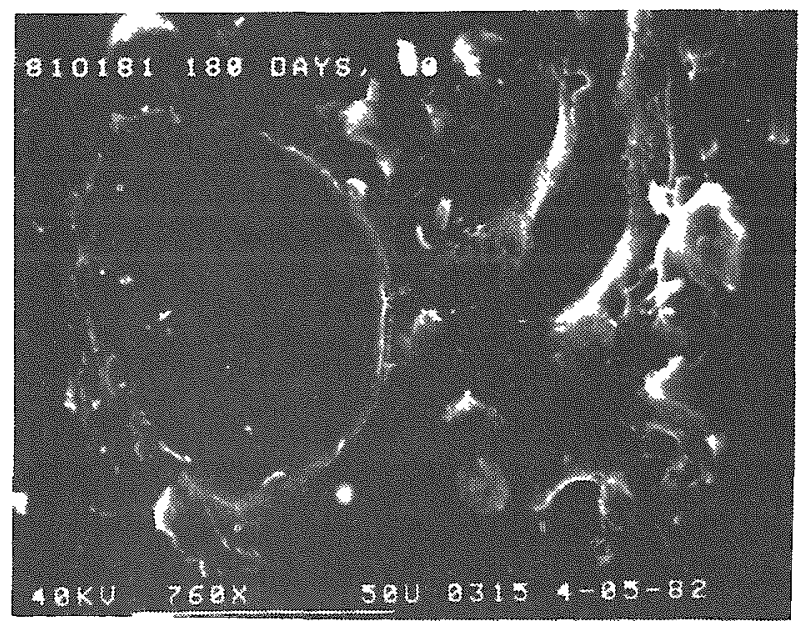

(e)

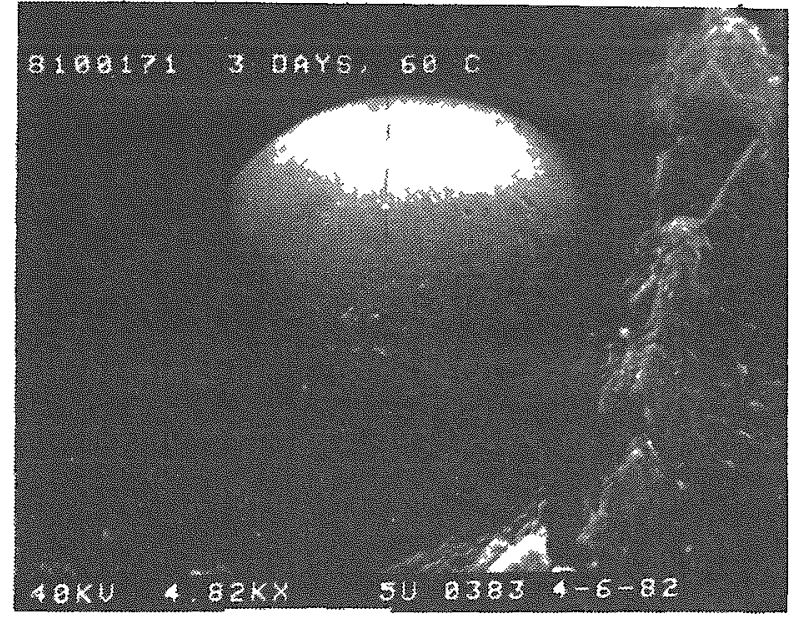

(b)

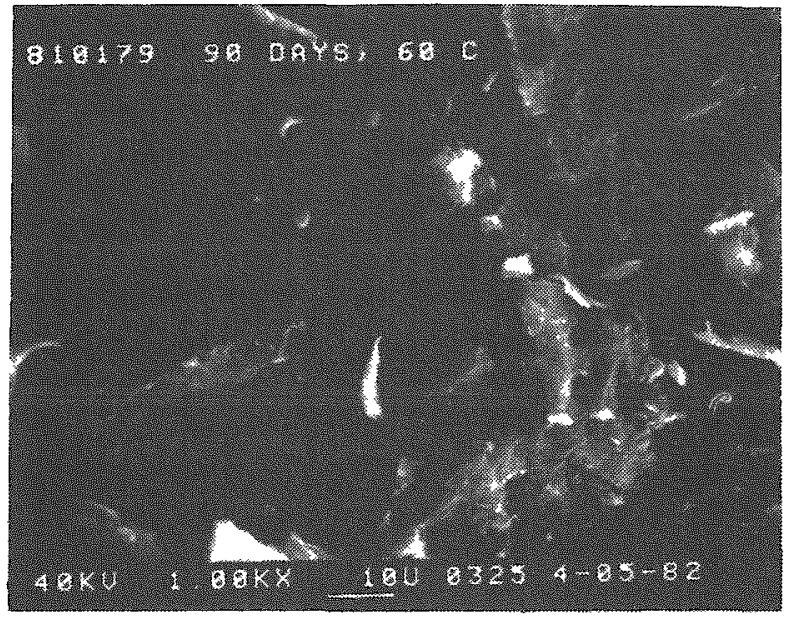

(d)

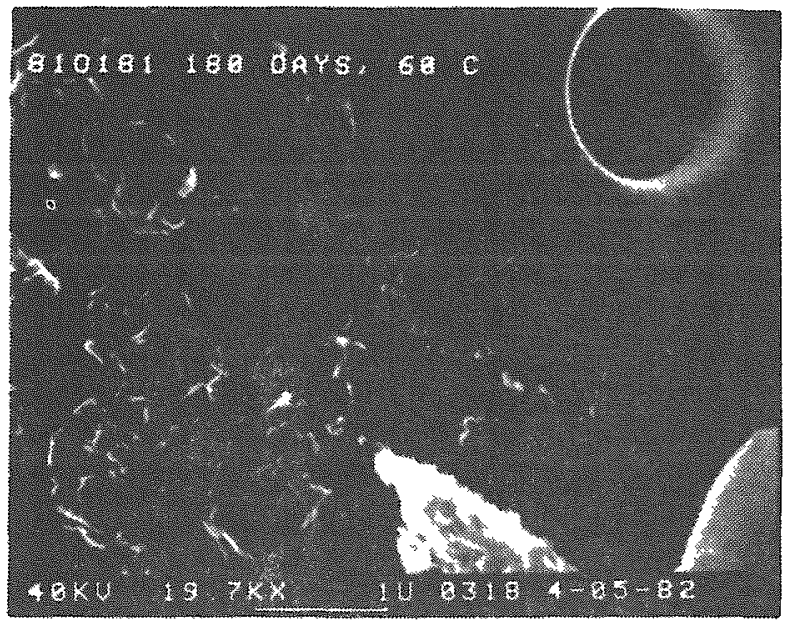

(I) 


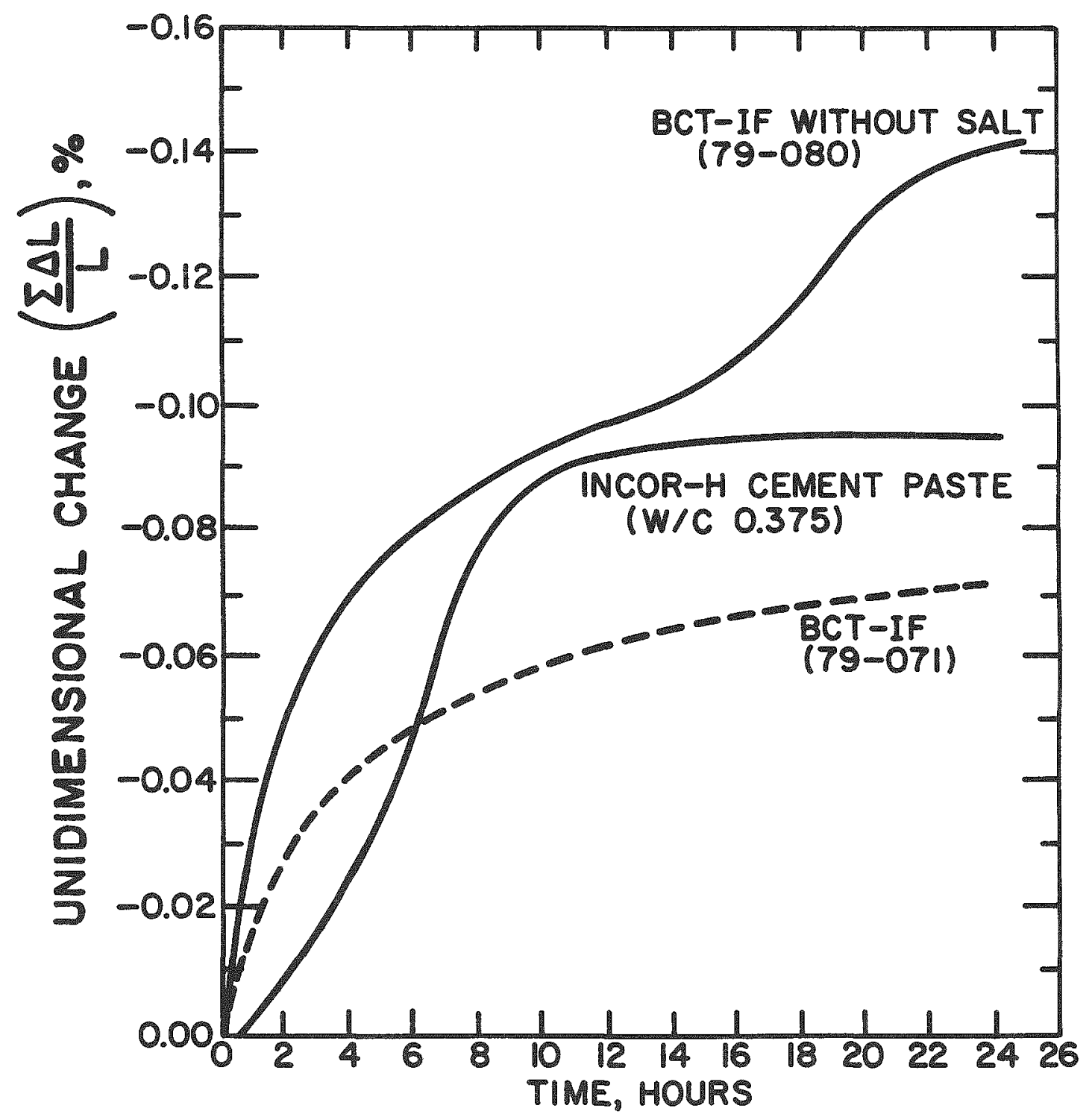

Figure 3.1.4. Unidimensional change of mixtures 79-071 and 79-080 compared to a neat cement paste. Room temperature hydration. 


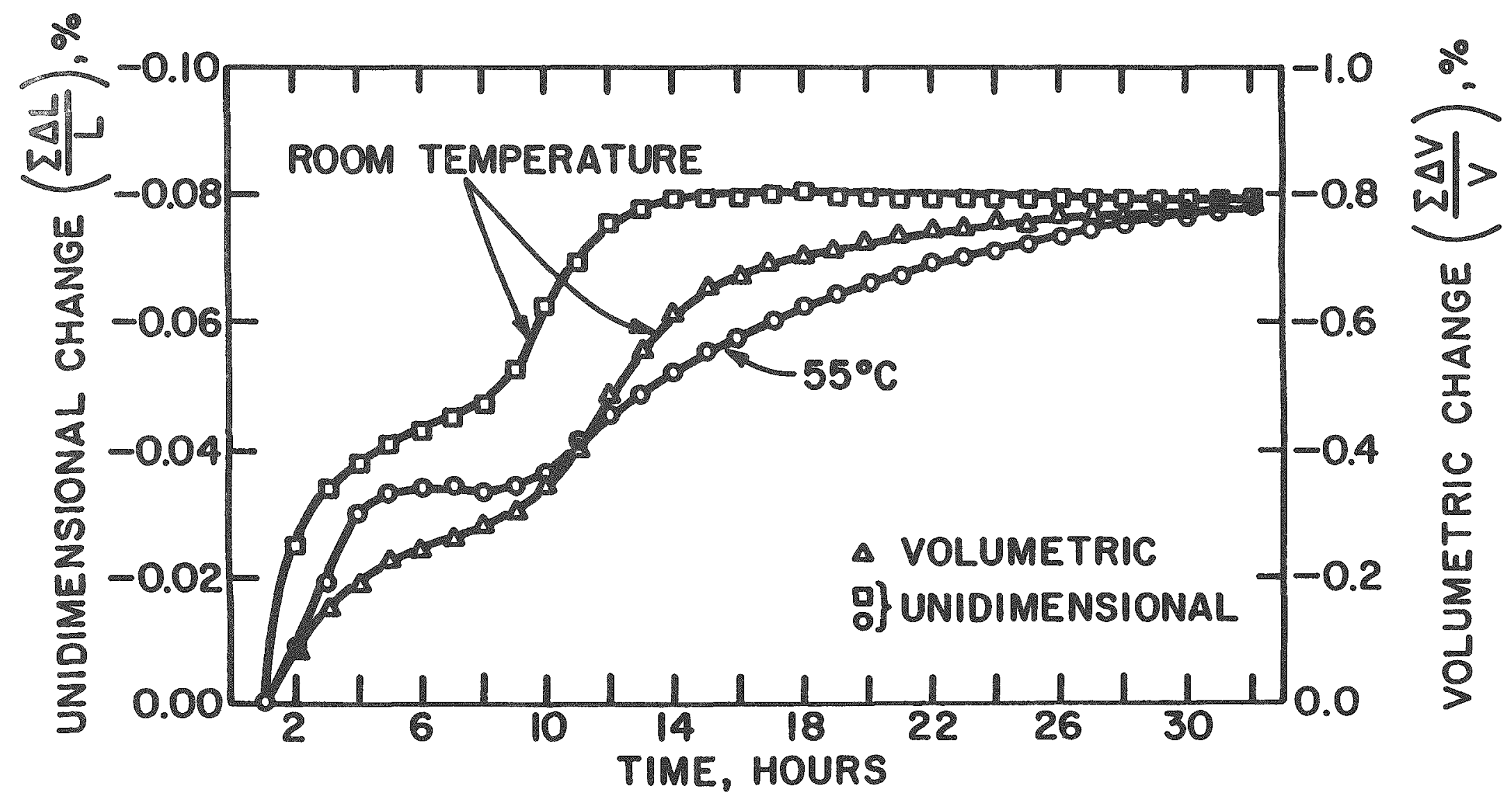




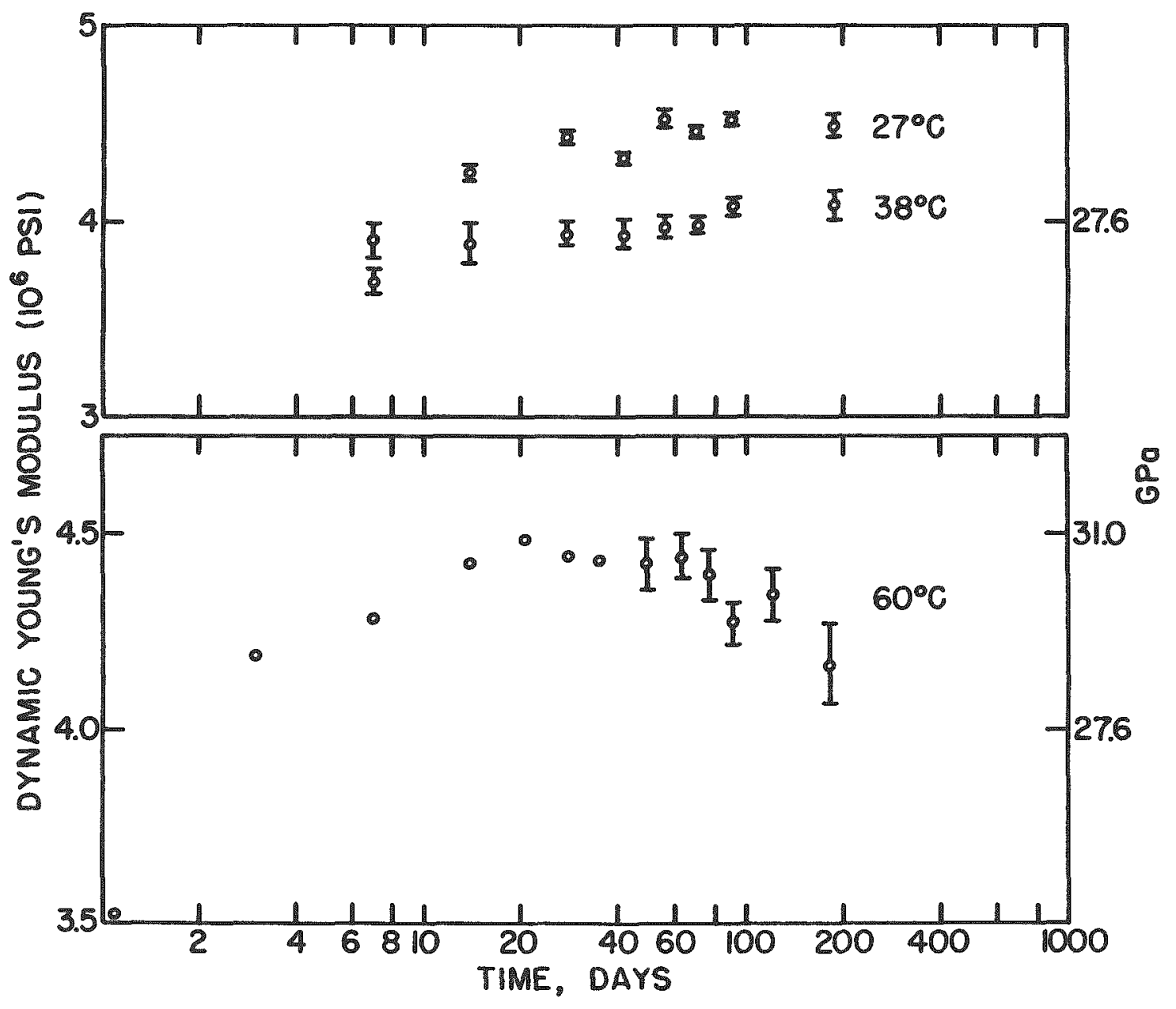


Table 3.1.10. Thermal conductivity of mixture 81-091 as a function of time and temperature $(\mathrm{W} / \mathrm{mK})$.

\begin{tabular}{|c|c|c|}
\hline \multirow{2}{*}{$\begin{array}{c}\text { specimen } \\
\text { age } \\
\text { (days) }\end{array}$} & \multicolumn{2}{|c|}{ curing temperature, ${ }^{\circ} \mathrm{C}$} \\
\hline & $27^{\circ}$ & $38^{\circ}$ \\
\hline 7 & 1.800 & 1.529 \\
\hline 14 & 2.103 & 1.512 \\
\hline 28 & 2.122 & 1.599 \\
\hline 56 & 2.494 & 2.270 \\
\hline
\end{tabular}

Compressive strengths reported previously for mixture 81-091 would lead one to believe that higher temperature curing at a given time would also result in higher Young's modulus and thermal conductivity. However, this is not the case. Relative to the $27^{\circ} \mathrm{C}$ curing condition, both Young's modulus and thermal conductivity data are reduced for the $38^{\circ} \mathrm{C}$ cure. These discrepancies are apparently due to differences in sample preparation from one day to another. 


\subsubsection{Discussion and Conclusions}

Four salt-containing and two salt-free derivative mixtures were investigated. All were sulfated and all eventually expanded. Each of the mixtures exhibited adequate strength development, and related physical and mechanical properties. One compositional feature appears to correlate with compressive strength: the percentage of salt saturation of the mixing water. In Figure 3.1.7 the appropriate percentages of salt saturation of five of these mixtures have been plotted against compressive strengths of the mixtures at 28 days (before any onset of cracking due to unrestrained expanion had taken place) and $60^{\circ} \mathrm{C}$ (a median temperature). The correlation is good, with most of the variation in compressive strength explained by the salt content of the mixing water. The salt (NaCl) content controls the phase content (relative proportion of Friedel's salt vs, ettringite), and affects the reactivity of the water. It also affects the morphology of the ettringite which is present. In the salt-free mixture, the ettringite is needle-shaped and may exhibit greater stress and contribute a reinforcing effect acting as fibers in the paste. In the salt-saturated mixture the ettringite/Friedel's salt is more stubby (Ogawa and Roy, 1981, 1982) and cannot impart this same effect. Furthermore, Friedel's salt has a platy, rather than needle-1ike morphology.

Results have shown that permeabilities of both salt-containing and saltfree mixtures are generally very low, especially in restrained specimens. Infiltration of water and migration of salt out of the samples was significant in specimens exposed to curing solutions after only one day hydration. Two distinctive modes of behavior were observed when such "wet" cured samples were compared with "dry" cured samples. It is apparent that accurate control of the initial chemical composition of a mixture is necessary to produce the desired properties of a seal material optimized for a specific environment.

In addition to temperature, the availability of water in a particular expansive salt-containing mixture probably controls the rate of formation and continued expansion of ettringite or an AFt phase. If water is restricted or its activity lowered by raising the chloride concentration, ettringite formation $\left[\mathrm{C}_{3} \mathrm{~A} \cdot 3 \mathrm{CaSO} \mathrm{S}_{4}\right.$. $32 \mathrm{H}_{2}$ o] which requires 32 molecules of water, will be slowed or even reversed while a competing reaction to form Friedel's salt $\left[\mathrm{C}_{3} \mathrm{~A} \cdot \mathrm{CaCl}_{2}{ }^{\circ} \mathrm{IOH}_{2} \mathrm{O}\right]$ or an $\mathrm{AFm}$ phase which contains only 10 molecules of water will play an increasingly more prominent role. Thus, balancing the total chemical composition including the 


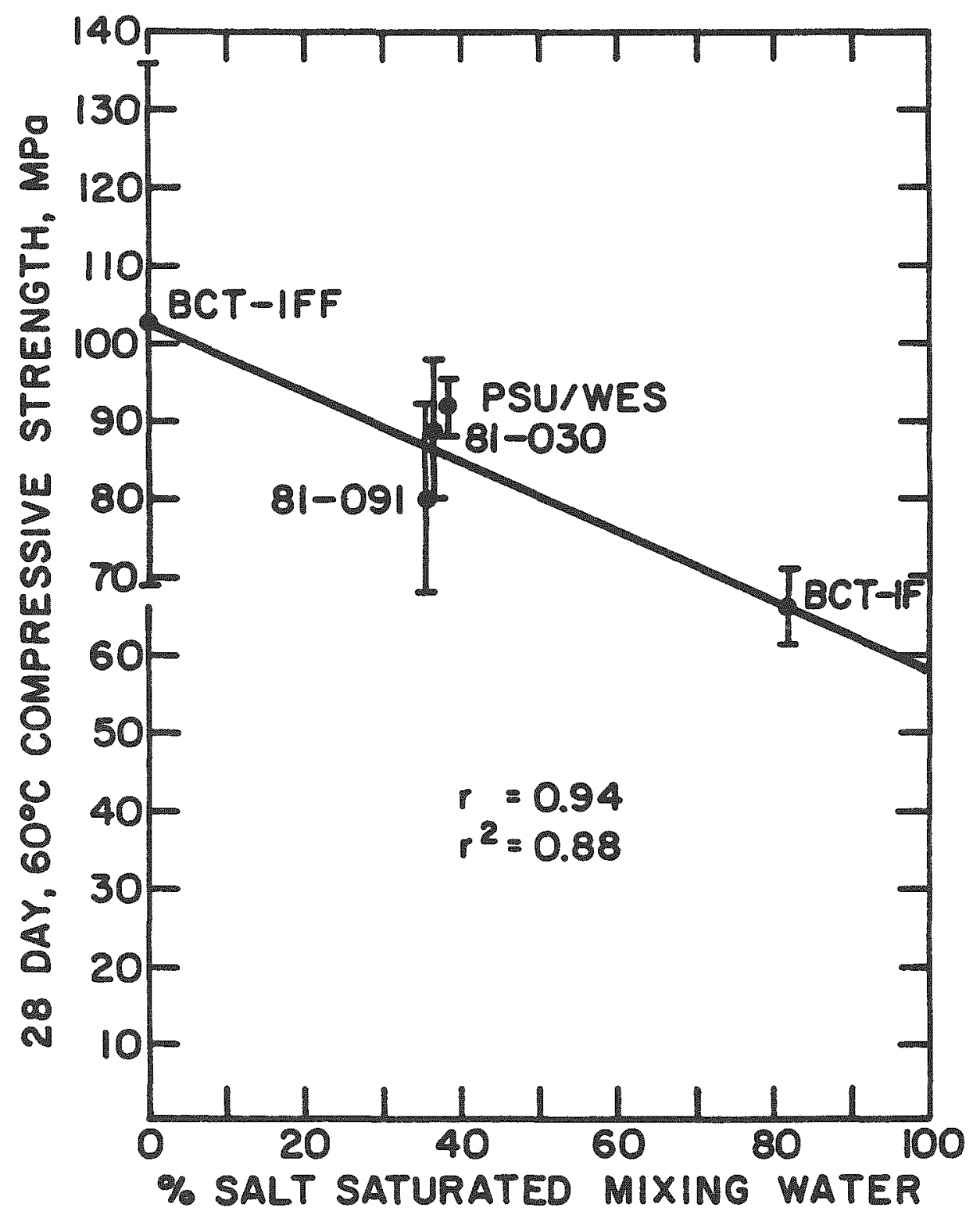

Figure 3.1.7. Correlation of compressive strength with \% salt saturation of mixing water $\left(28\right.$ days, $60^{\circ} \mathrm{C}$ ). 
water and salt content of the mixture and the environment is desirable to control the phase formation and the amount of expansion.

Expansiveness is not the only goal, but the nature of the contact of the wall rock with the mix solution during placement and long time curing is important. Chemical compatibility is necessary so that no undesirable phase changes will take place, as discussed later, in section 3.5 .

\subsection{FRESH WATER MIXTURES WITH POZZOLANIC ADMIXTURES}

\subsubsection{Introduction}

The mixtures in this section all contain some type of "siliceous" material(s) often termed a "pozzolan." These materials partially replace the cement

and are used to reduce free $\mathrm{Ca}(\mathrm{OH})_{2}$ and subsequently increase the strength. The nature and definition of pozzolans and pozzolanic reactions are discussed briefly in the following section.

\subsubsection{Nature of the Pozzolanic Reaction}

Many historical cultures knew about pozzolans. They found that the addition of certain naturally occurring volcanic ashes or pottery shards would enhance the properties of their early cements. By present-day convention, there are two types of pozzolans: those that occur naturally and those that are products or by-products of some industrial process; the latter are termed "artificial" pozzolans. The present work has emphasized the utilization of artificial pozzolans in combination with various commercial portland cements.

By definition, pozzolanic materials are ones "... which in themselves possess little or no cementitious value but will, in finely divided form and in the presence of moisture, chemically react with calcium hydroxide at ordinary temperatures to form compounds possessing cementitious properties" (ASTM C 618). According to this definition, ASTM class C fly ashes and blast furnace slags are not true pozzolans, since they are somewhat self-cementitious even though free lime reduction in cement pastes and concretes is achieved through use of these materials; however, the reduction is less than that achieved by adding equal amounts of ASTM class F fly ash or silica fume. In the stricter sense, they are cements. In addition to these materials, relatively unreactive finely-divided quartz or at the extreme, ASTM C 109 sand, have also been used in the experimental program. Using the broader definition, they 
too exhibit pozzolanic character; and given enough time, could enter into the reaction to a small extent.

Normally, siliceous materials which are relatively reactive are termed pozzolans, whereas very slow reacting materials such as quartz sand are termed inert aggregate. In the present situation these kinetic limitations are less important over the extraordinarily long time frame in which a repository seal must function. Therefore, the broader definition of pozzolanicity has been adopted in this report.

Artificial pozzolans such as fly ash, blast furnace slag, silica fumes and gels can be roughly classified into two groups. The first consists predominantly of "glassy" materials (fly ash and granulated blast furnace slag) which have formed from a melt and resemble super-cooled liquids. The glasses are metastable and thus possess excess free energy when compared with the crystalline anhydrous or hydrated counterparts. The second group consists of cryptocrystalIine to amorphous materials with very high surface areas. They have either condensed from a vapor phase or at some timewere sols or gels. This group of materials is best typified by the silica fumes, which are by-products of silicon metal or ferrosilicon alloy manufacture. Earlier research incorporated silica gels or calcined colloidal silicas (Roy et al., 1978). The mechanisms of reaction of the silica fume or silica gel in portland cement are slightly different from the glasses. The fumes and gels have very large surface energies associated with an extremely small particle size which is on the order of 0.1 um or smaller.

Recent work on fly ash-substituted cements has : demonstrated a mechanism of localized dissolution followed by topochemical and precipitative growth of C-S-H (Grutzeck et al., 1981b). The mechanism of silica fume incorporation in cement pastes is one in which a sol- or gel-like coating first forms which is very reactive, and thus the fume quickly becomes coated by C-S-H as it reacts with the calcium hydroxide in solution (Gruizeck et a1., 1982).

\subsubsection{Design of Experimental Cementitious Mixtures}

Materials have been designed for ultimate reduced free-calcium hydroxide content by incorporating pozzolanic materials, and for reduced water/cement (w/c) ratio by using water-reducing dispersants. Pozzolans obviously differed in reactivity, hence mixtures often included combinations of rapidly and slowly reacting materials together to lengthen the duration of the pozzolanic reaction. Such 
combinations have generated potential seal materials which have adequate strength

combined with permeabilities of less than $10^{-8}$ darcys $\left(10^{-11} \mathrm{~cm} \mathrm{sec}^{-1}\right)$.

Since a good contact between the host rock and the seal is thought to be important, slightly expansive seal formulations were also evaluated. A mechanism of expansion common to all mixtures was based on the formation of ettringite $\left(3 \mathrm{CaO} \cdot \mathrm{Al}_{2} \mathrm{O}_{3} \cdot 3 \mathrm{CaSO}_{4} \cdot 32 \mathrm{H}_{2} \mathrm{O}\right)$. To achieve this expansion, various calcium sulfates were added to the mixtures (which included lime and alumina) in their contents. Both salt and non-salt strata are penetrated in a potential repository site in bedded salt, hence both salt-containing and salt-free mixtures were investigated. The results of the salt-free experiments are detailed in the text of this section.

\section{2 .4 Viscosity}

To determine the proper water and admixture proportions for feasible emplacement, the rheological properties of potential mixtures were measured (Asaga and Roy, 1980). Shear stress was recorded as a function of shear rate, and apparent viscosities were recorded. Summary results for all mixtures are given in Table 3.2.1. All seven mixtures in Table 3.2.1 are very fluid. All mixtures showed a small and nearly insignificant yield point and each mixture exhibited shear thinning with time, with near plastic or pseudo-plastic flow behavior.

\subsubsection{Formulations}

Formulations for the eight mixtures in this section are given in Table 3.2.2. Compositions of starting materials are given in Appendix A. Additional details regarding some of these mixtures are given elsewhere (Roy et a1., 1982). The most important features are highlighted here.

The behavior of the fumes and dusts (collectively called silica fume) were found to be relatively similar in nature, due to their high surface areas. Reactivity was partially related to their state of agglomeration, which effectively increased their particle size above the nominal 0.1 um particle size which is common to a11 fumes and dusts. These agglomerations were partly dispersible under certain cement mixing conditions. Since these fumes were very high surface area, it was necessary to use a high-range water reducer to reduce the water demand of the formulated pastes.

The addition of $f l y$ ash to a cement paste or concrete usually causes a slower development in strength, but often results in physical and chemical property 


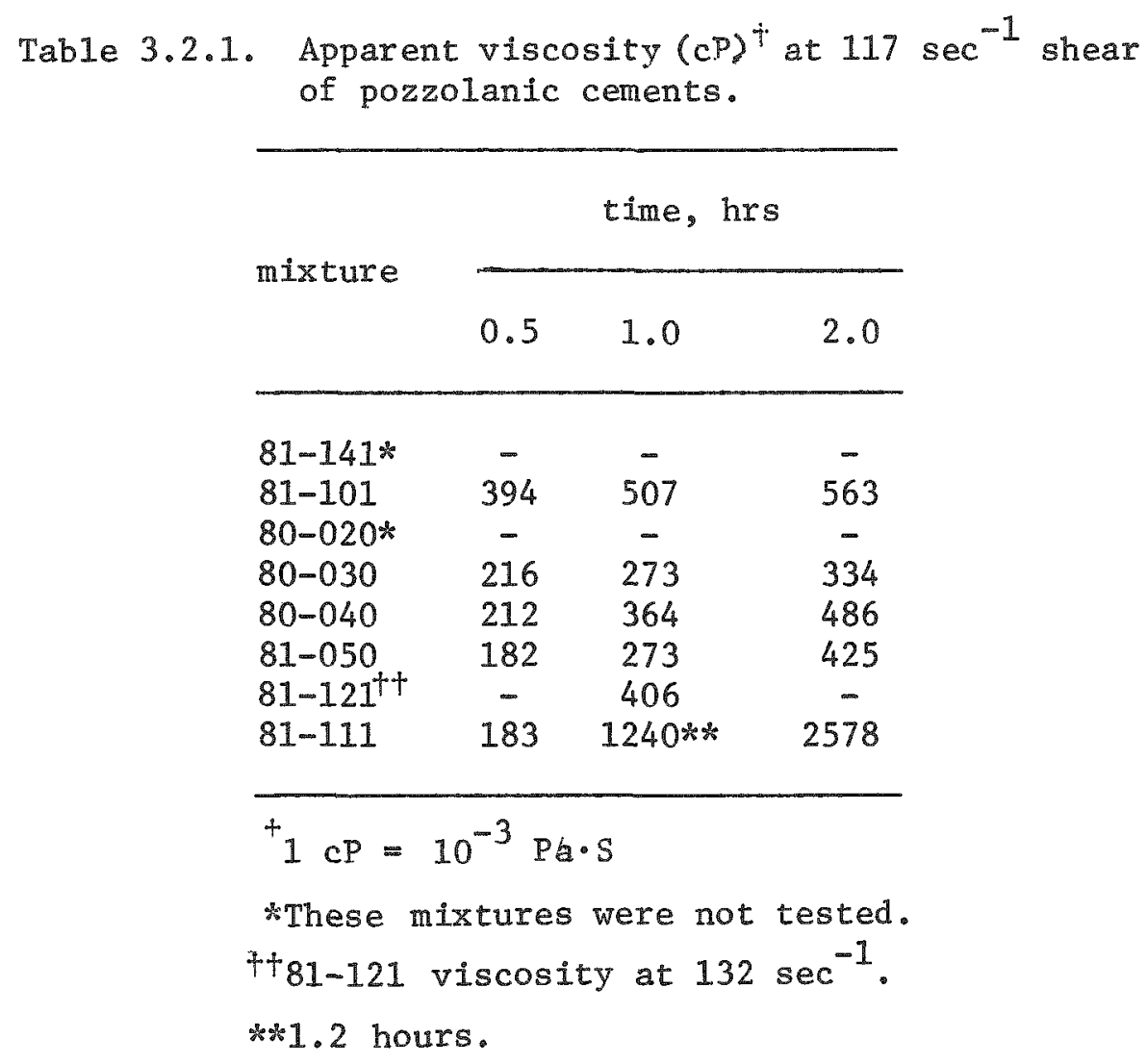

enhancement at later ages. However, the reaction mechanisms and stages in achieving the superior properties are not fully understood. Thus, fly ashcontaining mixtures appear to be candidate seal materials if their mechanisms of reaction are better understood so that their long-range properties can be predicted. 
Table 3.2.2. Formulations of pozzolan-containing mixtures (weights in grams).

\begin{tabular}{|c|c|c|c|c|c|c|c|c|}
\hline \multirow{2}{*}{$\begin{array}{c}\text { Code } \\
\text { No. }\end{array}$} & \multicolumn{8}{|c|}{ mixture } \\
\hline & $81-141$ & $81-101$ & $80-020$ & $80-030$ & $80-040$ & $81-050$ & $81-121$ & $81-111$ \\
\hline
\end{tabular}

\begin{tabular}{|c|c|c|c|c|c|c|c|c|c|}
\hline class $H$ cement & $\mathrm{H}-8, \mathrm{H}-7$ & 74.81 & 68.57 & 69.4 & 69.4 & 64.9 & 65.81 & 64.47 & 69.4 \\
\hline Litepoz & B44 & 25.19 & 23.09 & $-\infty$ & - & $-\infty$ & -- & - & -- \\
\hline gypsea1 & A31 & $-\infty$ & 8.41 & -- & -- & $-\infty$ & 4.03 & 2.23 & - \\
\hline ferrosilicon dust & B31 & -- & $-\infty$ & - & - & 15.3 & 15.13 & 8.37 & - \\
\hline Ohio fume & B27 & -- & -- & 15.3 & -- & $-\infty$ & - & - & 15.3 \\
\hline fly ash & B25 & - & - & -- & - & $-\infty$ & - & -- & 15.3 \\
\hline Alabama fume & B24 & $-\infty$ & - & - & 15.3 & -- & -- & -- & - \\
\hline Min-u-sil (30 $\mu \mathrm{m})$ & B23 & - & $-\infty$ & 15.3 & 15.3 & 15.3 & -- & -- & - \\
\hline slag & B19 & - & $-\infty$ & -- & - & - & 15.03 & 24.93 & -- \\
\hline C 109 sand & $\mathrm{C} 14, \mathrm{C} 16$ & - & -- & -- & $-\infty$ & -- & 49.25 & 65.04 & - \\
\hline Mighty & A36 & -- & 1.12 & - & -- & -- & -- & 1.98 & -- \\
\hline Mighty $150 *$ & A3 & $-\infty$ & -- & 1.4 & 1.40 & 1.4 & 2.09 & -- & 1.8 \\
\hline defoamer & A27 & 0.02 & 0.02 & - & -- & -- & - & -- & - \\
\hline water & E01,E05 & 27.50 & 29.63 & 25.0 & 25.0 & 30.15 & 30.01 & 27.50 & 30.0 \\
\hline$w / c$ & & 0.37 & 0.43 & 0.36 & 0.36 & 0.43 & 0.46 & 0.43 & 0.43 \\
\hline $\mathrm{w} / \mathrm{s}$ & & 0.28 & 0.30 & 0.30 & 0.30 & 0.35 & 0.30 & 0.25 & 0.30 \\
\hline
\end{tabular}

*1iquid contains $41 \%$ solids. 
A fly ash selected for mixtures in this section was one of the high-lime varieties because of greater availability in the western United States. This ash in itself is slightly cementitious when mixed with water.

The first two fly ash formulations (81-141, 81-101) were mixed and molded as either cylinders ( 25.4 by $50.8-\mathrm{mm}$ long) or cubes (50.8 - mm). Molds were sealed with grease and immersed in $38^{\circ} \mathrm{C}$ tap water for 24 hours. After demolding, the samples continued curing at $38^{\circ} \mathrm{C}$ in saturated $\mathrm{Ca}(\mathrm{OH})_{2}$ solution until time of testing. Based on expected underground temperatures, the temperature chosen for hydration was $38^{\circ} \mathrm{C}$, which was found to accelerate hydration reactions, but not significantly alter reaction products. Compressive strengths and $\mathrm{x}-\mathrm{ray}$ diffraction data were primary evaluation instruments, along with the SEM microstructural studies. Samples used for SEM examination were freeze-dried.

Three of the mixtures were formulated specifically to compare the performance of different silica sources. Mixtures bearing PSU numbers 80-020,80-030, and 80-040, contained equal portions of reactive silica "dust," and the less reactive coarser quartz. These mixtures were prepared as slurries according to API mixing procedures, molded as cylinders (25.4 by $50.8-\mathrm{mm}$ long); precured in the sealed molds at selected temperatures, demolded at 24 hours and cured at temperature in $\mathrm{Ca}(\mathrm{OH})_{2}$-saturated water until tested.

The final three mixtures in this section contain combinations of silica fume and slag or silica fume and class F fly ash. All mixtures were formulated with high-range water reducers. Formulations PSU 81-050, 81-121, and 81-111 were mixed as pastes/grouts/sandy grouts according to API procedures, molded as cylinders (25.4 by 50.8-mm long), precured at temperature in Teflon-coated sealed brass molds, demolded at 24 hours and cured as a function of time at temperature in saturated $\mathrm{Ca}(\mathrm{OH})_{2}$ solution. These mixtures were tested for compressive strength, microhardness, bulk density and also examined by $x$-ray diffraction and SEM analysis. As before, samples were tested either "as-cured" or freeze-dried.

\section{2 .6 Results}

Compressive Strength. Values for the mixtures studied in this section are given in Table 3.2.3. The strength of the cement + fly ash mixture (81-141) increased with time, reaching the very high strength of $123 \mathrm{MPa}$ at 56 days. The strength increase began similarly with the sulfate-containing mixture (81-101), but the rate diminished between 28 and 56 days. Since the compositions of mixture 
Table 3.2.3. Compressive strength of pozzolanic mixtures (MPa).

\begin{tabular}{|c|c|c|c|c|c|c|c|c|c|}
\hline \multirow{2}{*}{$\begin{array}{l}\text { specimen } \\
\text { age } \\
\text { (days) }\end{array}$} & \multirow{2}{*}{$\begin{array}{l}\text { cure } \\
\text { temp. } \\
\left({ }^{\circ} \mathrm{C}\right)\end{array}$} & \multicolumn{2}{|c|}{ fly ash } & \multicolumn{3}{|c|}{ funed } & \multicolumn{2}{|c|}{ fume + slag } & \multirow{2}{*}{$\begin{array}{l}\text { fume }+ \\
\text { fly ash } \\
81-111\end{array}$} \\
\hline & & $81-141$ & $81-101$ & $80-020$ & $80-030$ & $80-040$ & $81-050$ & $81-121$ & \\
\hline 3 & $\begin{array}{l}27 \\
38 \\
45 \\
60 \\
90\end{array}$ & 59.7 & 51.7 & & & & & $\begin{array}{r}76.4 \\
98.8 \\
108.4 \\
94.7\end{array}$ & $\begin{array}{l}18.0 \\
28.6 \\
51.3 \\
91.5\end{array}$ \\
\hline 7 & $\begin{array}{l}27 \\
38 \\
45 \\
60 \\
90\end{array}$ & 89.1 & 81.6 & $\begin{array}{l}46.2 \\
90.6 \\
92.4 \\
93.8\end{array}$ & $\begin{array}{l}87.8 \\
92.1 \\
91.8 \\
74.3\end{array}$ & $\begin{array}{r}78.7 \\
101.5 \\
82.6 \\
100.7\end{array}$ & $\begin{array}{r}76.7 \\
83.1 \\
117.0 \\
89.7\end{array}$ & $\begin{array}{r}61.2 \\
7.4 .1 \\
108.2 \\
100.1\end{array}$ & $\begin{array}{l}72.8 \\
92.0 \\
86.6 \\
98.7\end{array}$ \\
\hline 14 & $\begin{array}{l}27 \\
38 \\
45 \\
60 \\
90\end{array}$ & & 88.5 & $\begin{array}{l}52.7 \\
74.3 \\
92.7 \\
62.7\end{array}$ & $\begin{array}{l}107.2 \\
109.9 \\
119.3 \\
106.2\end{array}$ & $\begin{array}{r}52.7 \\
70.8 \\
27.1 \\
110.8\end{array}$ & $\begin{array}{l}85.7 \\
87.6 \\
84.7 \\
68.2\end{array}$ & & $\begin{array}{l}70.0 \\
88.2 \\
95.3 \\
50.3\end{array}$ \\
\hline 28 & $\begin{array}{l}27 \\
38 \\
45 \\
60 \\
90\end{array}$ & 109.5 & 90.7 & $\begin{array}{l}113.2 \\
112.1 \\
107.0 \\
116.2\end{array}$ & $\begin{array}{l}98.8 \\
97.7 \\
99.7 \\
92.4\end{array}$ & $\begin{array}{r}99.1 \\
94.7 \\
119.2 \\
95.5\end{array}$ & $\begin{array}{r}90.4 \\
103.6 \\
99.1 \\
64.3\end{array}$ & $\begin{array}{r}80.5 \\
80.7 \\
96.1 \\
116.3\end{array}$ & $\begin{array}{l}70.5 \\
76.6 \\
85.3 \\
72.9\end{array}$ \\
\hline 56 & $\begin{array}{l}27 \\
38 \\
45 \\
60 \\
90\end{array}$ & 123.0 & 91.8 & & & & & $\begin{array}{r}87.6 \\
82.3 \\
120.5 \\
114.7\end{array}$ & $\begin{array}{r}117.3 \\
97.4 \\
130.3 \\
106.8\end{array}$ \\
\hline 90 & $\begin{array}{l}27 \\
38 \\
45 \\
60 \\
90\end{array}$ & & & & & & & $\begin{array}{l}130.2 \\
138.0 \\
136.1 \\
121.7\end{array}$ & \\
\hline
\end{tabular}


81-141 and 81-101 are otherwise similar it appears that the sulfate content of mixture 81-101 was influential.

The compressive strengths achieved by mixtures 80-020, 80-030 and 80-040 through 28 days of curing are relatively high in comparison to what has already been discussed, having strengths between 75 and $100 \mathrm{MPa}$ at 7 days. All mixtures achieved a 28-day compressive strength between 95 and $120 \mathrm{MPa}$.

Mixtures 81-040 and 81-121 are similar mixtures containing sand, both designed to be somewhat expansive (81-050 more so than 81-121). Also, mixture 81-121 contains about half as much ferrosilicon dust ( $\sim 8 \%$ based on cementitious solids) as 81-050. Both developed high strengths at an early age (7 days was the earliest test age for 81-050, and 3 days for 81-121). The highest fumecontent mixture, 81-050, showed the most steady strength development between 7 and 28 days when cured at $27^{\circ}$ and $45^{\circ} \mathrm{C}$. The higher-temperature $60^{\circ}$ and $90^{\circ} \mathrm{C}$ samples developed high 7-day strengths, leveling off later. Longer-term data are required to determine if this trend continues. Mixture 81-121 showed very high strengths at $45^{\circ}, 60^{\circ}$, and $90^{\circ} \mathrm{C}$ even at 3 days, probably reflecting the higher slag contents, and the $90^{\circ} \mathrm{C}$ sample showed a very steady pattern of strength increase with time. As expected, the $27^{\circ}$ sample had the lowest strength at 3 days. It is not clear at this stage whether the pattern of strength development is controlled to a greater extent by ettringite formation (see Roy et al., 1981; Wakeley eta1., 1981a; and Ogawa and Roy, 1981, 1982, for discussion of effect of ettringite formation on expansion and strength) or other factors, such as porosity and pore structure (Parker and Roy, 1982).

Mixture 81-111 was a grout containing a low-lime class $F$ fly ash as well as silica fume. It was similar to the formulations for mixtures 80-020, 80-030, and 80-040 (closest to 80-040), but with the $30 \mu \mathrm{m}$ quartz being replaced by a class $F$ f1y ash. A more consistent strength gain pattern is shown by 81-111, compared to its counterpart, 80-040. The greatest rate of strength gain of mixture 81-111 is again between 3 and 7 days, except for the $90^{\circ} \mathrm{C}$ samples, at which temperature the reactivities of the fume and/or fly ash are high even at 3 days. Strengths were high at all temperatures by 7 days, and were highest at 56 days.

Microhardness. These values which are more closely correlated with Young's modulus than compressive strength, are useful particularly for study of small specimens and in the absence of replicates. The current results (Appendix B) show relatively high values for the materials at all temperatures and curing 
times. An occasional unusually high microhardness value was observed, which correlated with a high compressive strength measurement, having a low standard deviation. The microhardness values for mixtures 81-050, 81-121, and 81-111 tend to gradually increase with time.

Bulk Density. The values given in Table 3.2 .4 relate to constituents, porosity, degree of expansion, and provide general quality control. Compared with the total series, mixture 81-121 shows higher densities, reflecting the higher slag content relative to fume, and higher sand content. Generally, densities increase with time and temperature of hydration, signifying a conventional hydration sequence.

The silica fume + class $F$ fly ash mixture (81-111) generally does not have the same high early strength as do the mixtures containing slag, since the slag is initially more reactive than the fly ash. By 56 days the strengths of the fly ash mixture and the slag mixture are very much the same, reflecting the later reactivity of the fly ash. However, comparisons are not directly applicable between sand-containing (81-121) and sand-free (81-111) mixtures, since mortars usually have lower strengths than sand-free mixtures. The slag and sandcontaining mortars (81-121) however, were found to have about the highest strengths of any of the materials investigated.

Permeability. Water permeability data for the three silica fume-substituted cements (80-020,80-030 and 80-040) are given in Table 3.2.5 as a function of time and temperature. The fume-substituted cements have very 1ow permeabilities. Mixture 80-040 had very low permeability (below detection limit) under all conditions of curing, which is surprising since it had such a wide variation in compressive strength. Water permeabilities of mixtures 81-050, 81-121 and 81-111 are given in Table 3.2.6. Generally, the values are very low, with only one value falling at $\sim 10^{-7}$ darcys. No permeability measurements were made on mixtures 81-141 and 81-101, which were formulated primarily for studies of reaction mechanisms.

X-ray Diffraction. Summaries of phase data for mixtures 81-141 and 81-101 are given in Table 3.2.7. Phases are given in decreasing order of relative intensity, as applicable. Hydrated calcium aluminate phases were of ten present throughout the hydration history of the samples, which is not entirely unexpected since the $\mathrm{fly}$ ash contains more than 17 wt $\% \mathrm{Al}_{2} \mathrm{O}_{3}$. In addition, the molar $\mathrm{Ca} / \mathrm{Si}$ ratio of the $\mathrm{fIy}$ ash is comparable to that in $\mathrm{C}-\mathrm{S}-\mathrm{H}$ and therefore it is 
Table 3.2.4. Bu1k density of pozzolanic mixtures.

\begin{tabular}{|c|c|c|c|c|c|c|c|c|c|}
\hline \multirow{2}{*}{$\begin{array}{l}\text { specimen } \\
\text { age } \\
\text { (days) }\end{array}$} & \multirow{2}{*}{$\begin{array}{l}\text { cure } \\
\text { temp. } \\
\left({ }^{\circ} \mathrm{C}\right)\end{array}$} & \multicolumn{8}{|c|}{ mixture } \\
\hline & & $81-141$ & $81-101$ & $80-020$ & $80-030$ & $80-040$ & $81-050$ & $81-121$ & $81-111$ \\
\hline 3 & $\begin{array}{l}27 \\
38 \\
45 \\
60 \\
90\end{array}$ & & 1.76 & & & & & $\begin{array}{l}2.08 \\
2.17 \\
2.02 \\
2.12\end{array}$ & $\begin{array}{l}1.71 \\
1.70 \\
1.69 \\
1.76\end{array}$ \\
\hline 7 & $\begin{array}{l}27 \\
38 \\
45 \\
60 \\
90\end{array}$ & & 1.76 & $\begin{array}{l}1.84 \\
1.85 \\
1.86 \\
1.90\end{array}$ & $\begin{array}{l}1.87 \\
1.89 \\
1.89 \\
1.96\end{array}$ & $\begin{array}{l}1.71 \\
1.69 \\
1.72 \\
1.73\end{array}$ & $\begin{array}{l}1.96 \\
1.99 \\
2.01 \\
2.04\end{array}$ & $\begin{array}{l}2.19 \\
2.18 \\
2.21 \\
2.20\end{array}$ & $\begin{array}{l}1.74 \\
1.74 \\
1.81 \\
1.85\end{array}$ \\
\hline 14 & $\begin{array}{l}27 \\
38 \\
45 \\
60 \\
90\end{array}$ & $\begin{array}{l}\mathbf{n} \\
0\end{array}$ & 1.79 & $\begin{array}{l}1.85 \\
1.85 \\
1.86 \\
1.91\end{array}$ & $\begin{array}{l}1.89 \\
1.89 \\
1.91 \\
1.96\end{array}$ & $\begin{array}{l}1.68 \\
1.67 \\
1.68 \\
1.71\end{array}$ & $\begin{array}{l}1.99 \\
2.00 \\
2.01 \\
2.03\end{array}$ & & $\begin{array}{l}1.77 \\
1.78 \\
1.81 \\
1.89\end{array}$ \\
\hline 28 & $\begin{array}{l}27 \\
38 \\
45 \\
60 \\
90\end{array}$ & $\begin{array}{l}\mathrm{d} \\
\mathrm{a} \\
\mathrm{t} \\
\mathrm{a}\end{array}$ & 1.94 & $\begin{array}{l}1.82 \\
1.85 \\
1.85 \\
1.87\end{array}$ & $\begin{array}{l}1.83 \\
1.85 \\
1.97 \\
1.99\end{array}$ & $\begin{array}{l}1.70 \\
1.68 \\
1.73 \\
1.77\end{array}$ & $\begin{array}{l}1.92 \\
1.91 \\
1.92 \\
1.92\end{array}$ & $\begin{array}{l}2.10 \\
2.11 \\
2.16 \\
2.14\end{array}$ & $\begin{array}{l}1.70 \\
1.66 \\
1.74 \\
1.78\end{array}$ \\
\hline 56 & $\begin{array}{l}27 \\
38 \\
45 \\
60 \\
90\end{array}$ & & 1.87 & & & & & $\begin{array}{l}2.07 \\
2.09 \\
2.10 \\
2.13\end{array}$ & $\begin{array}{l}1.78 \\
1.85 \\
1.91 \\
1.90\end{array}$ \\
\hline 90 & $\begin{array}{l}27 \\
38 \\
45 \\
60 \\
90\end{array}$ & & & & & & & $\begin{array}{l}2.13 \\
2.15 \\
2.18 \\
2.16\end{array}$ & \\
\hline
\end{tabular}


Table 3.2.5. Water permeabilities of fume- and dust-substituted cenents (darcy $\cong \mu m^{2}$ ).

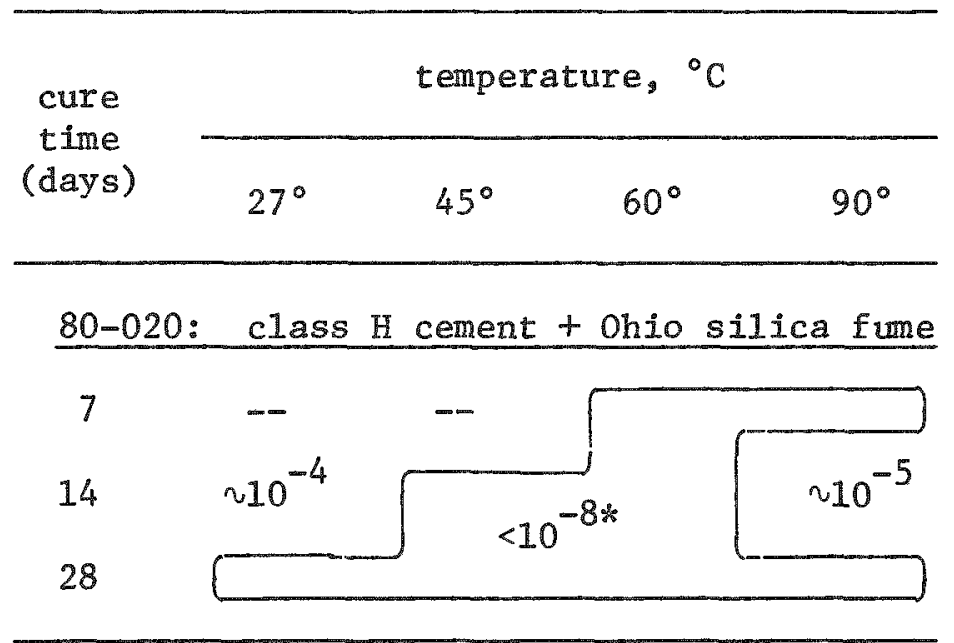

80-030: class H cement + Alabama silica fume

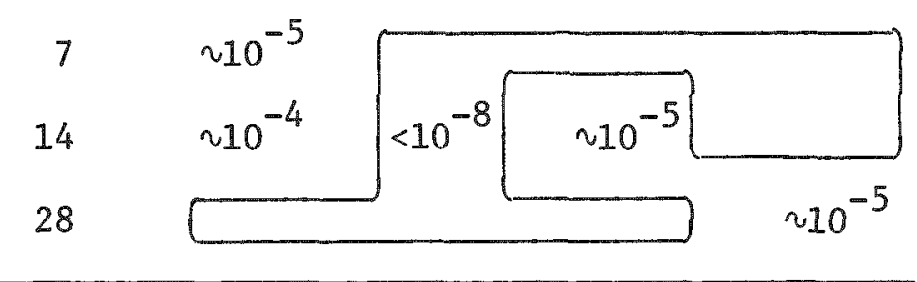

80-040: class $H$ cement + Icelandic ferrosilicon dust

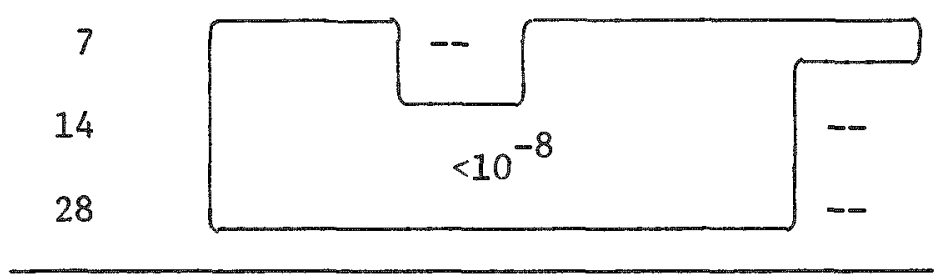

Hit

-- (missing data). 
Table 3.2.6. Water permeability of complex fume- and dust-substituted cements (darcys $\cong \mu \mathrm{m}^{2}$ ).

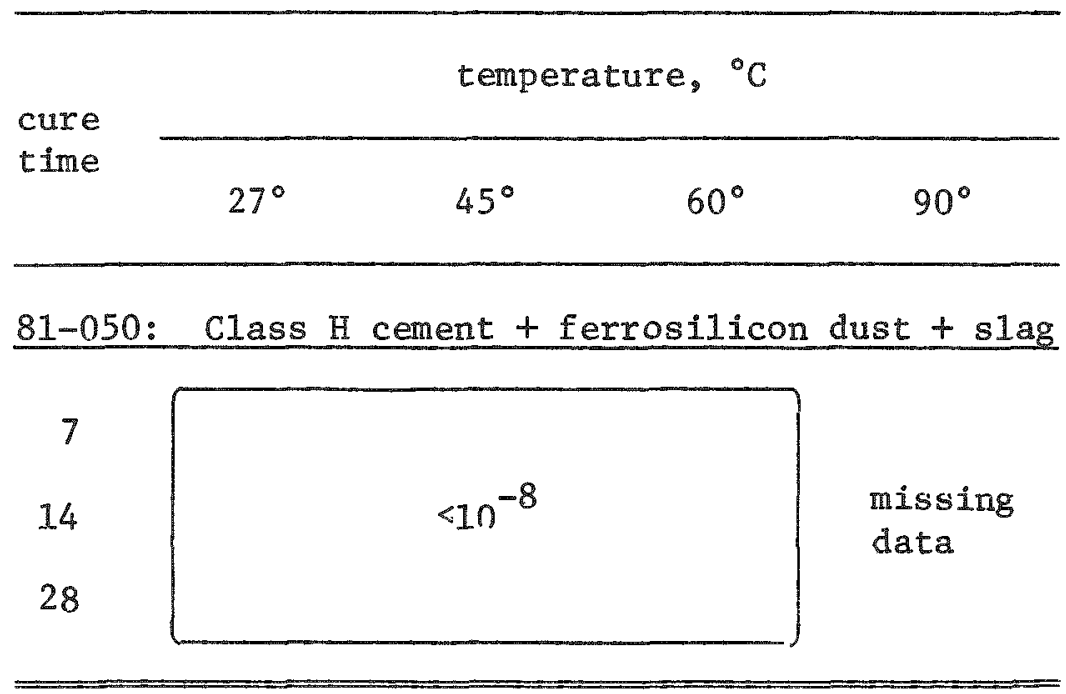

81-121: class H cement + ferrosilicon dust + slag
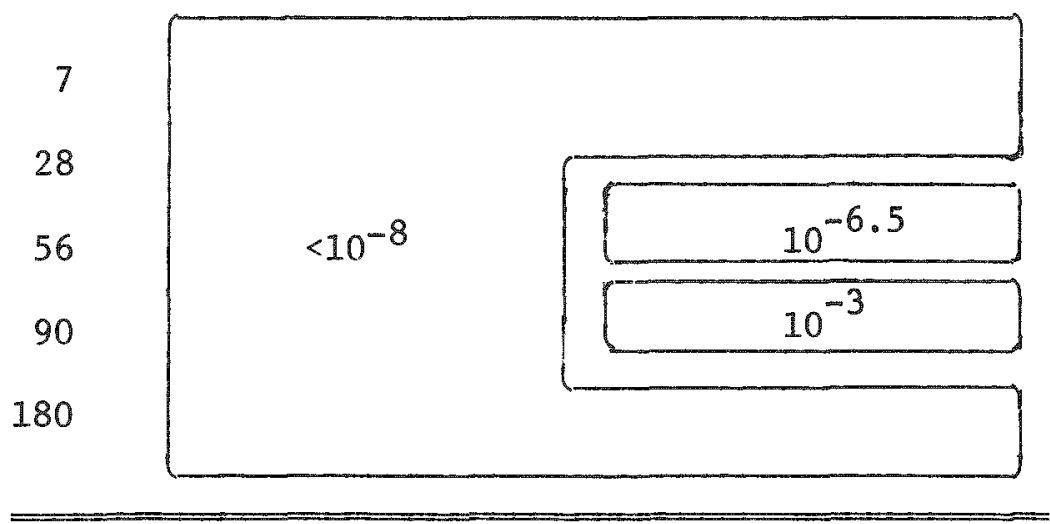

81-111: class $H$ cement + silica fume + fly ash

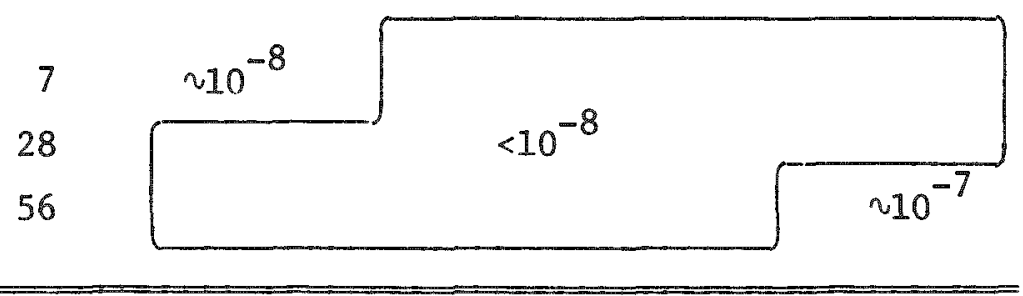


Table 3.2.7. X-ray diffraction phase data for samples cured at $38^{\circ} \mathrm{C}$ in $\mathrm{Ca}(\mathrm{OH})_{2}$ solution.*

\begin{tabular}{|c|c|c|}
\hline $\begin{array}{c}\text { hydration } \\
\text { days }\end{array}$ & $\begin{array}{c}81-141 \\
\text { class } H+f 1 y \text { ash }\end{array}$ & $\begin{array}{c}\text { 81-101 } \\
\text { class } \mathrm{H}+\mathrm{fly} \text { ash } \\
+ \text { sulfate }\end{array}$ \\
\hline 3 & $\begin{array}{c}\text { unhydrated } \mathrm{PC} \\
\mathrm{Ca}(\mathrm{OH})_{2} \\
\text { quartz } \\
\text { ettringite } \\
\mathrm{C}_{2} \mathrm{ASH}_{8} \\
\mathrm{C}_{2} \mathrm{AH}_{8}(\mathrm{Tr})\end{array}$ & no data \\
\hline 7 & $\begin{array}{c}\text { unhydrated } \mathrm{PC} \\
\mathrm{Ca}(\mathrm{OH})_{2} \\
\text { quartz } \\
\mathrm{C}_{2} \mathrm{ASH}_{8} \\
\mathrm{C}-\mathrm{S}-\mathrm{H} \\
\text { ettringite }(\mathrm{Tr}) \\
\text { monosulfate }(\mathrm{Tr})\end{array}$ & $\begin{array}{c}\text { unhydrated } \mathrm{PC} \\
\mathrm{Ca}(\mathrm{OH})_{2} \\
\text { ettringite } \\
\text { quartz } \\
\mathrm{C}_{2} \mathrm{ASH}_{8} \\
\mathrm{C}^{\mathrm{C}-\mathrm{S}-\mathrm{H}} \\
\mathrm{C}_{4} \mathrm{AH}_{13}(\mathrm{Tr})\end{array}$ \\
\hline 14 & no data & \begin{tabular}{|} 
unhydrated $\mathrm{PC}$ \\
ettringite \\
$\mathrm{Ca}(\mathrm{OH})_{2}$ \\
quartz \\
$\mathrm{C}-\mathrm{S}-\mathrm{H}$
\end{tabular} \\
\hline 28 & $\begin{array}{c}\text { unhydrated } \mathrm{PC} \\
\mathrm{Ca}(\mathrm{OH})_{2} \\
\text { quartz } \\
\mathrm{C}_{2} \mathrm{ASH}_{8} \\
\mathrm{C}-\mathrm{S}-\mathrm{H} \\
\mathrm{C}_{4} \mathrm{AH}_{13} \\
\text { monosulfate (Tr) }\end{array}$ & $\begin{array}{l}\text { unhydrated } \mathrm{PC} \\
\mathrm{Ca}(\mathrm{OH})_{2} \\
\text { ettringite } \\
\text { quartz } \\
\mathrm{C}-\mathrm{S}-\mathrm{H} \\
\mathrm{C}_{2} \mathrm{ASH}_{8}(\mathrm{Tr})\end{array}$ \\
\hline
\end{tabular}

*Conventional cement nomenclature is used: $\mathrm{C}=\mathrm{CaO}$ $\mathrm{A}=\mathrm{Al}_{2} \mathrm{O}_{3}, \overline{\mathrm{S}}=\mathrm{SO}_{3}, \mathrm{~S}=\mathrm{SiO}_{2}, \mathrm{H}=\mathrm{H}_{2} \mathrm{O}, \mathrm{F}=\mathrm{Fe}_{2} \mathrm{O}_{3}$. In addition, $\mathrm{PC}=$ portland cement, $\mathrm{Tr}=$ trace. 
likely that much alumina will be removed from the reaction zone. In mixture 81-141, ettringite $\left(\mathrm{C}_{3} \mathrm{~A} \cdot 3 \mathrm{CS} \cdot \mathrm{H}_{32}\right)$ and $\mathrm{C}_{2} \mathrm{AH}_{8}$ were formed early, but later reacted to form monosulfoaluminate $\left(\mathrm{C}_{3} \mathrm{~A} \cdot \mathrm{CS} \cdot \mathrm{H}_{12}\right)$ and $\mathrm{C}_{4} \mathrm{AH}_{13^{\circ}}$. In addition, $\mathrm{C}_{2} \mathrm{ASH}_{8}$ (Stratling's compound) was always present throughout the history of hydration of this sample. In the sulfated mixture (81-101), the trisulfoaluminate, ettringite, was dominant. Small amounts of $\mathrm{C}_{2} \mathrm{ASH}_{8}$ were also detected from time to time. All mixtures contained $\mathrm{Ca}(\mathrm{OH})_{2}, \mathrm{C}-\mathrm{S}-\mathrm{H}$ and unhydrated portland cement phases.

The $x$-ray diffraction sumary data for mixtures 80-020, 80-030 and 80-040 are presented in Table 3.2.8. In all three formulations at temperatures above $27^{\circ} \mathrm{C}$ the free $\mathrm{Ca}(\mathrm{OH})_{2}$ had reacted with the fume or dust to produce additional $\mathrm{C}-\mathrm{S}-\mathrm{H}$, and was no longer detected by $\mathrm{x}$-ray diffraction. At $27^{\circ} \mathrm{C}$, the free $\mathrm{Ca}(\mathrm{OH})_{2}$ still present tended to decrease with time. Its presence at $27^{\circ}$ and not at higher temperatures reflects the kinetics of reaction.

$\mathrm{X}$-ray diffraction data for mixtures $81-050,81-121$ and $81-111$ are given in Table 3.2.9. Mixture 81-121 is a modification of 81-050, having increased sand and slag, and lesser percentages of ferrosilicon dust, calcium sulfate, and water. However, the x-ray data are still similar except that the mixture 81-050 with the higher dust content proved to be more effective at reducing the free $\mathrm{Ca}(\mathrm{OH})_{2}$ content at an earlier time than 81-121. (It had a slightly higher w/c ratio and lower slag content, also.) Ettringite was present in 81-050 mixtures through $45^{\circ} \mathrm{C}$, while in $81-121$ ettringite was also found at $60^{\circ} \mathrm{C}$ at some test dates. $X$-ray diffraction data for mixture 81-111 were relatively straightforward, giving very similar results to those prsented for other fume- and dust-containing cements given in Table 3.2.7. Free $\mathrm{Ca}(\mathrm{OH})_{2}$ reduction was relatively rapid, having taken place even in the $27^{\circ} \mathrm{C}$ samples at 28 and 56 days. Both silica fume and fly ash may have an effect in reducing free lime, the latter probably at later ages. Ettringite was found as an additional phase at al1 times at $27^{\circ}$ and $45^{\circ} \mathrm{C}$.

SEM Data. SEM examination was carried out on six of the eight mixtures. Since some data for these mixtures (81-141, 81-101, 80-020,80-030,80-040, and 81-050) are presented elsewhere (Roy et al., 1982), only a summary of the findings is given here.

The pattern of fly ash hydration which evolves in fly ash-containing mixtures 81-141 and 81-101 is one of in situ hydration of the fly ash spheres, which are gradually consumed in the hydration reaction. The glass spheres are replaced by radiating clusters or bundles of fibrous $\mathrm{C}-\mathrm{S}-\mathrm{H}$, which in cross-section has a typical honey-comb appearance. As the spheres are consumed, radiating 
Table 3.2.8. X-ray diffraction data for fume- and dust-substituted cements.*

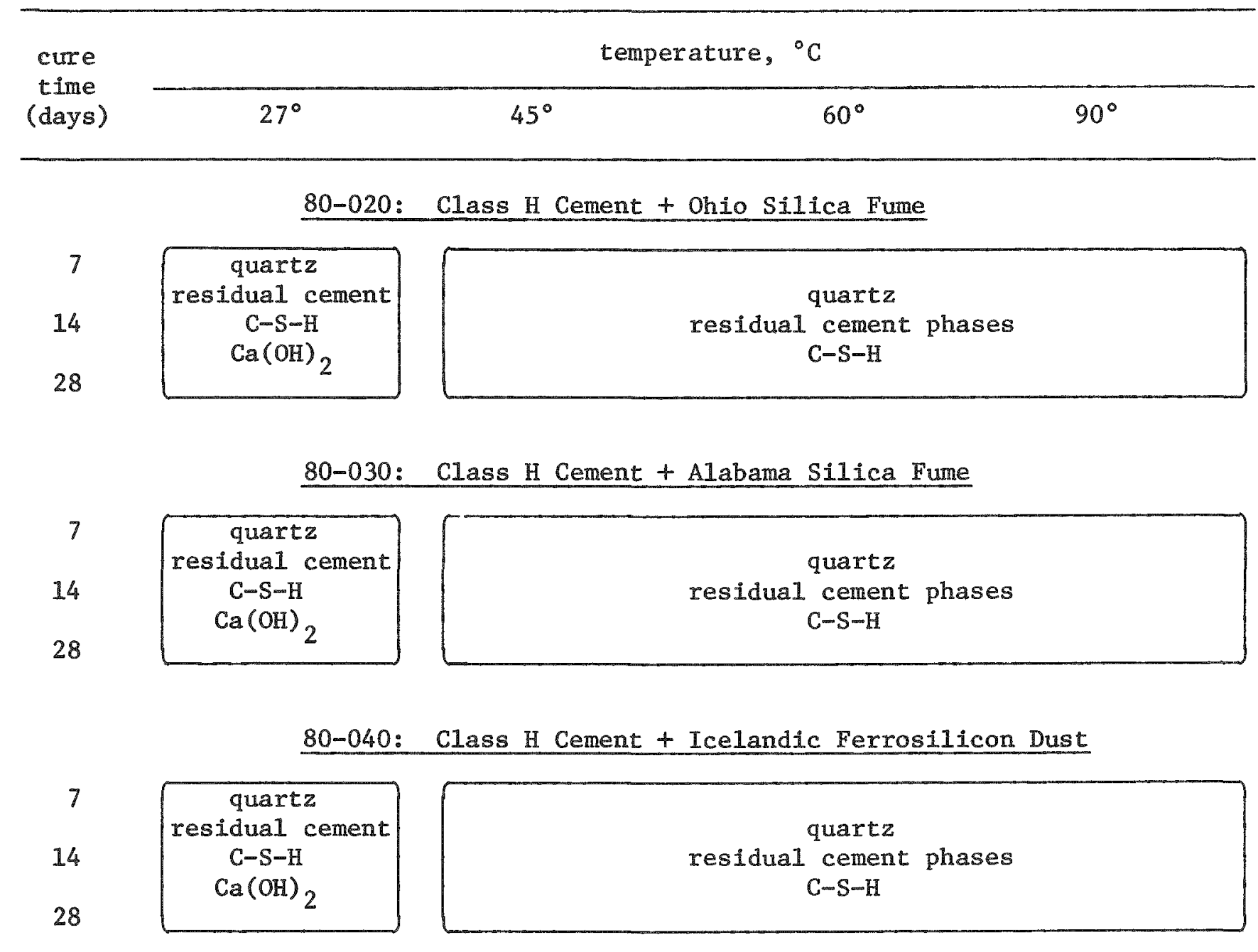

*Conventional cement nomenclature is used: $\mathrm{C}=\mathrm{CaO}, \mathrm{S}=\mathrm{SiO}_{2}, \mathrm{H}=\mathrm{H}_{2} \mathrm{O}$. 
Table 3.2.9. X-ray diffraction data for ferrosilicon dust + slag- and silica fume + fly ash-substituted cements.*

\begin{tabular}{|c|c|c|c|c|}
\hline \multirow{2}{*}{$\begin{array}{l}\text { cure } \\
\text { time } \\
\text { (days) }\end{array}$} & \multicolumn{4}{|c|}{ temperature, } \\
\hline & $27^{\circ}$ & $45^{\circ}$ & $60^{\circ}$ & $90^{\circ}$ \\
\hline
\end{tabular}

81-050: Class H Cement + Ferrosilicon Dust + S1ag + CaSO + Sand

7

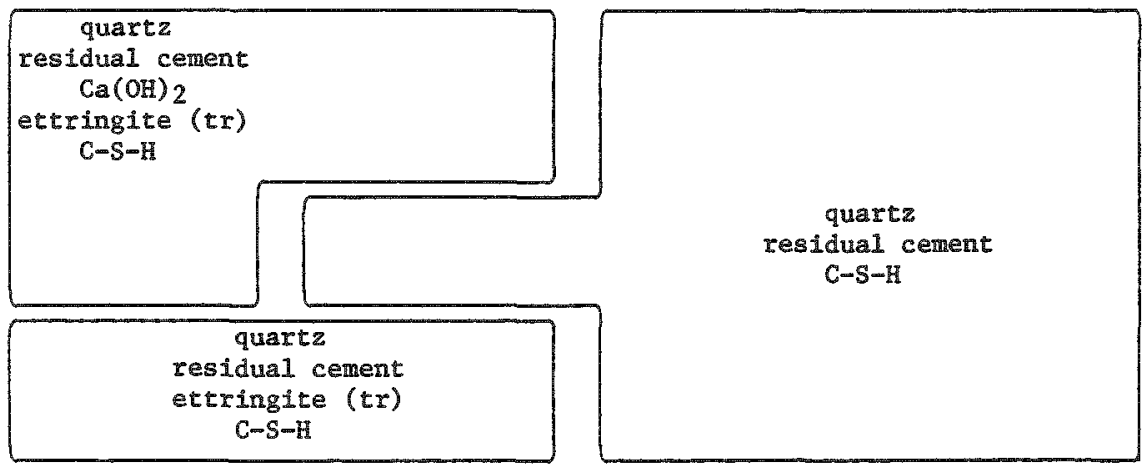

81-121: Class H Cement + Ferrosilicon Dust + $51 a g+\mathrm{CaSO}_{4}+\mathrm{Sand}$

3

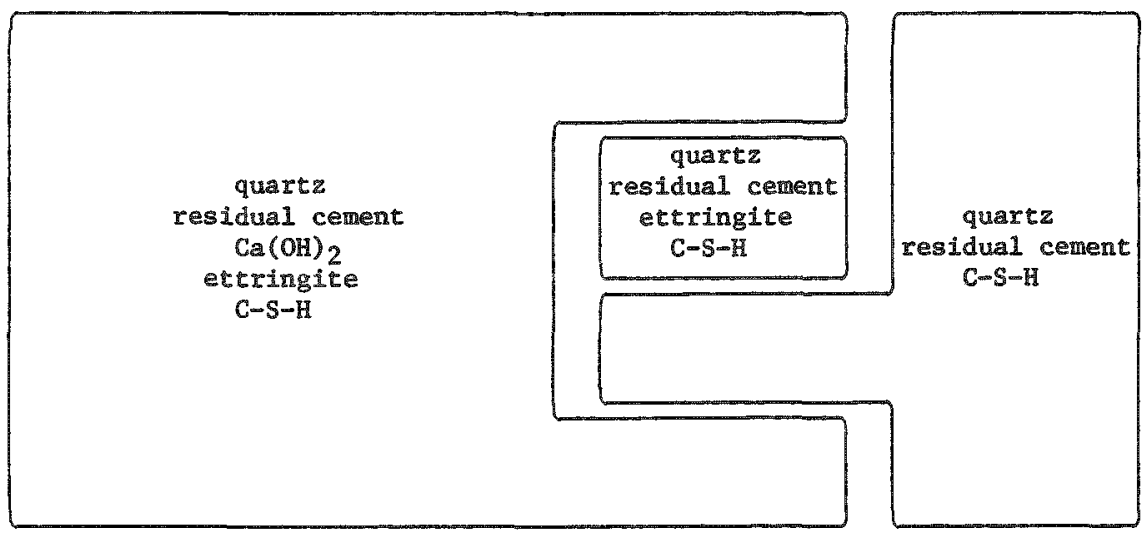

81-111: Class H Cement + Silica Fume + Fly Ash

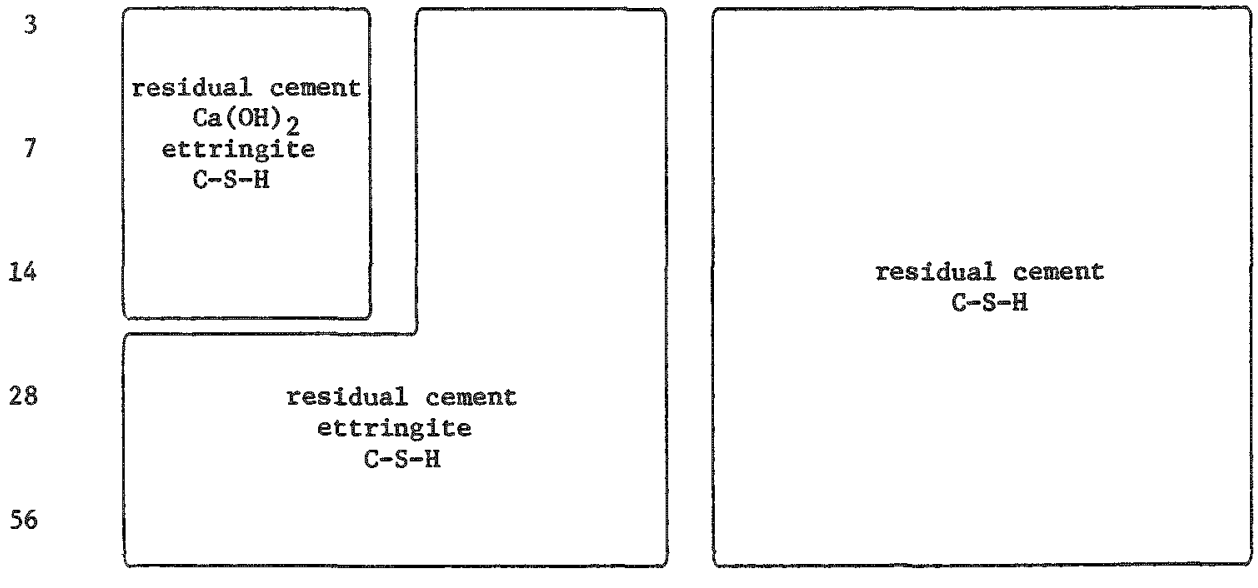

Conventional cement nomenclature is used: $\mathrm{C}=\mathrm{CaO}, \mathrm{S}=\mathrm{S} 1 \mathrm{O}_{2}, \mathrm{H}=\mathrm{H}_{2} \mathrm{O}, \mathrm{Tr}=\mathrm{trace}$. 
fibers grow inward to fill the space. At first, bonding of the C-S-H material to the sphere is necessarily weak, becoming progressively stronger with time as the $\mathrm{C}-\mathrm{S}-\mathrm{H}$ densifies with progressive hydration.

Mixture 81-101 also shows progressive hydration of the fly ash, but since excess sulfate is present, the potential for substantial ettringite formation exists. The $x$-ray diffraction data confirm the presence of ettringite and it is assumed that the rod-1ike or prismatic crystals present in the matrix are mainly ettringite (also see Grutzeck et a1., 1981b).

SEM images for the fume- and dust-substituted cements (80-020, 80-030 and 80-040) contained features which were nearly identical from formulation to formulation. Recent work with ferrosilicon dust with $\mathrm{Ca}(\mathrm{OH})_{2}$ solutions and cement mistures has resulted in the postulation of a mechanism of reaction whereby the fume or dust first consumes water to form a silica sol or "gel," which in turn combines with $\mathrm{Ca}(\mathrm{OH})_{2}$ available in solution to form $\mathrm{C}-\mathrm{S}-\mathrm{H}$ (see Figure 3.2.1). The application of this mechanism of gel formation and subsequent agglomeration of the fume and dust spheres into larger silica-rich particles, has been used to explain the majority of behavioral features of the silica fume and dust-substituted cements. Details of the mechanism and implications drawn from this model are presented in Grutzeck et al. (1982).

SEM data for mixture 81-050 are similar to those presented for mixture 81-141 and 81-101. The influence of temperature and time on reaction rate is obvious. The higher temperature or longer duration specimens show effects of densification and tendency to produce less ettringite and more $\mathrm{C}-\mathrm{S}-\mathrm{H}$ from the ferrosilicon dust.

Other Tests. Dynamic Young's modulus data are presented for mixture 80-020 at $60^{\circ} \mathrm{C}$ in Figure 3.2 .2 . As in the compressive strength data, the modulus data tend to plateau at 7 to 14 days with a gradual nearly linear ( $\log$ ) increase thereafter.

Dimensional change data for mixture $81-111$ for the first 24 hours of curing are given in Figure 3.2.3. Three plots for different samples of varying length are given. If rates of change are plotted, these are nearly identical. A rapid rate of shrinkage is observed through 6-8 hours, followed by a plateau lasting through 12 hours followed by another stage of renewed shrinkage through 19-20 hours. Compared with the expansive mixture 81-091 reported on in section 3.1, this mixture shows nearly twice as much shrinkage. However, other features of the curves are very simllar. 

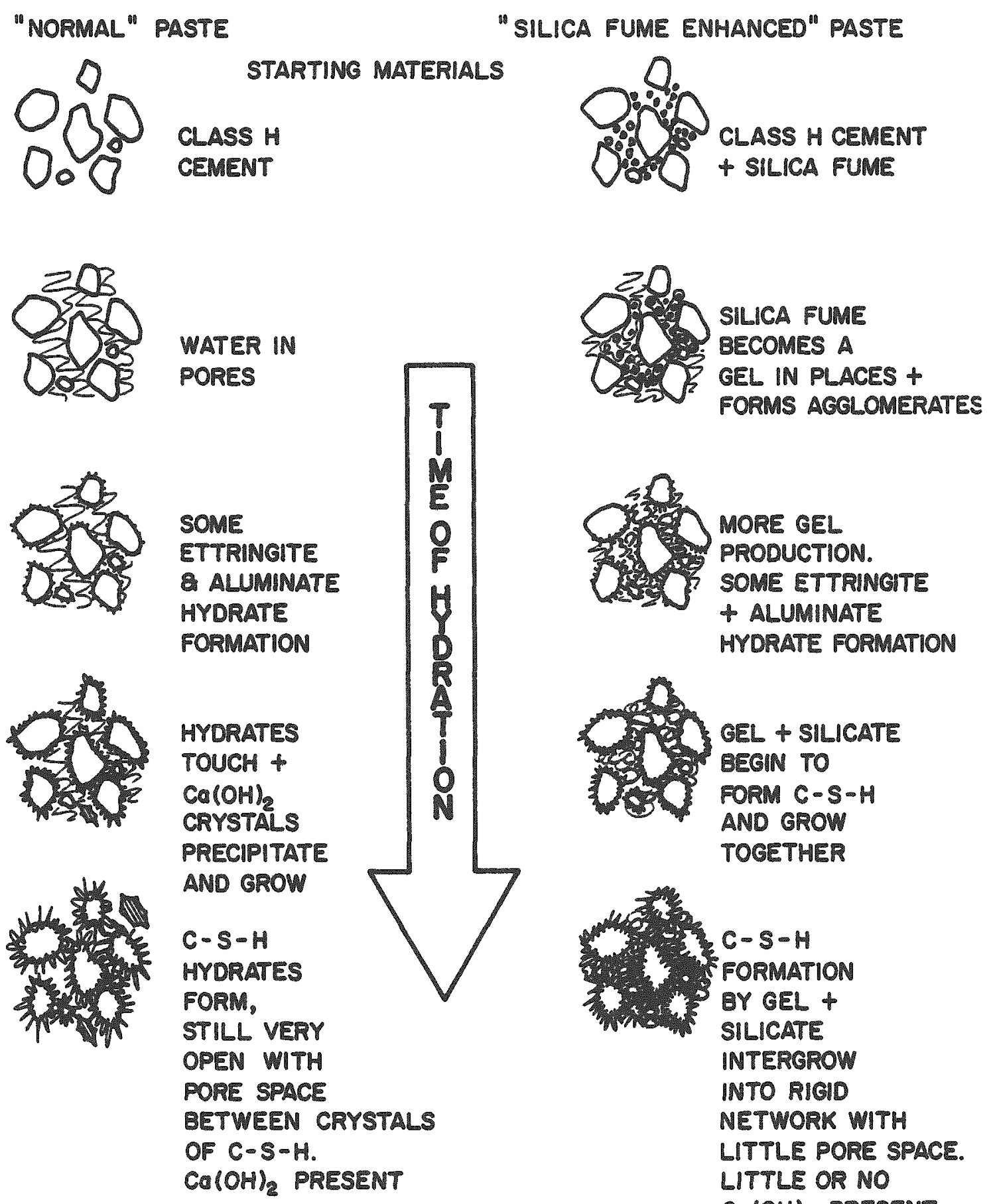

MORE GEL PRODUCTION. SOME ETTRINGTE + aluminate MYORATE FORMATION

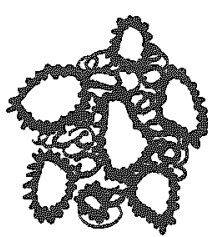

GEL + SILICATE BEGIN TO FORM C-S-H ANO GROW TOGETHER

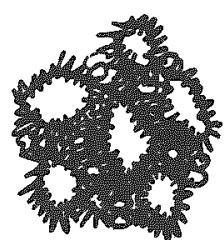

$C-S-H$ FORMATION BY CEL + SILICATE INTERGROW INTO RIGD NETWORK WITH LITTLE PORE SPACE. LITTLE OR NO COIOH/2 PRESENT

Figure 3.2.1. Mechanism of hydration of a normal paste and a "silica-fumeenhanced" paste. 


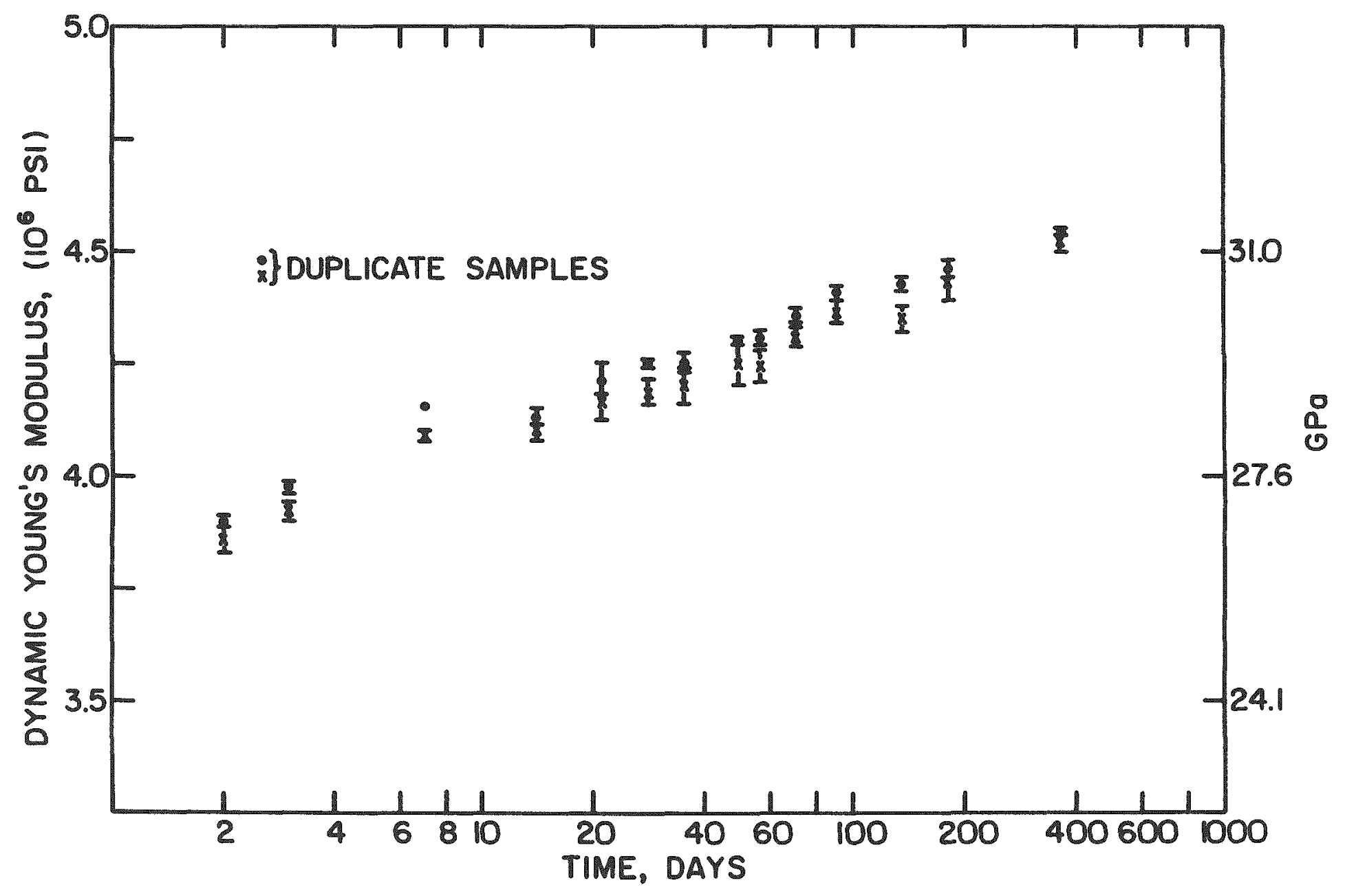

Figure 3.2.2. Dynamic Young's modulus for mixture $80-020$ hydrated at $60^{\circ} \mathrm{C}$ in saturated $\mathrm{Ca}(\mathrm{OH}) 2$ solution. 


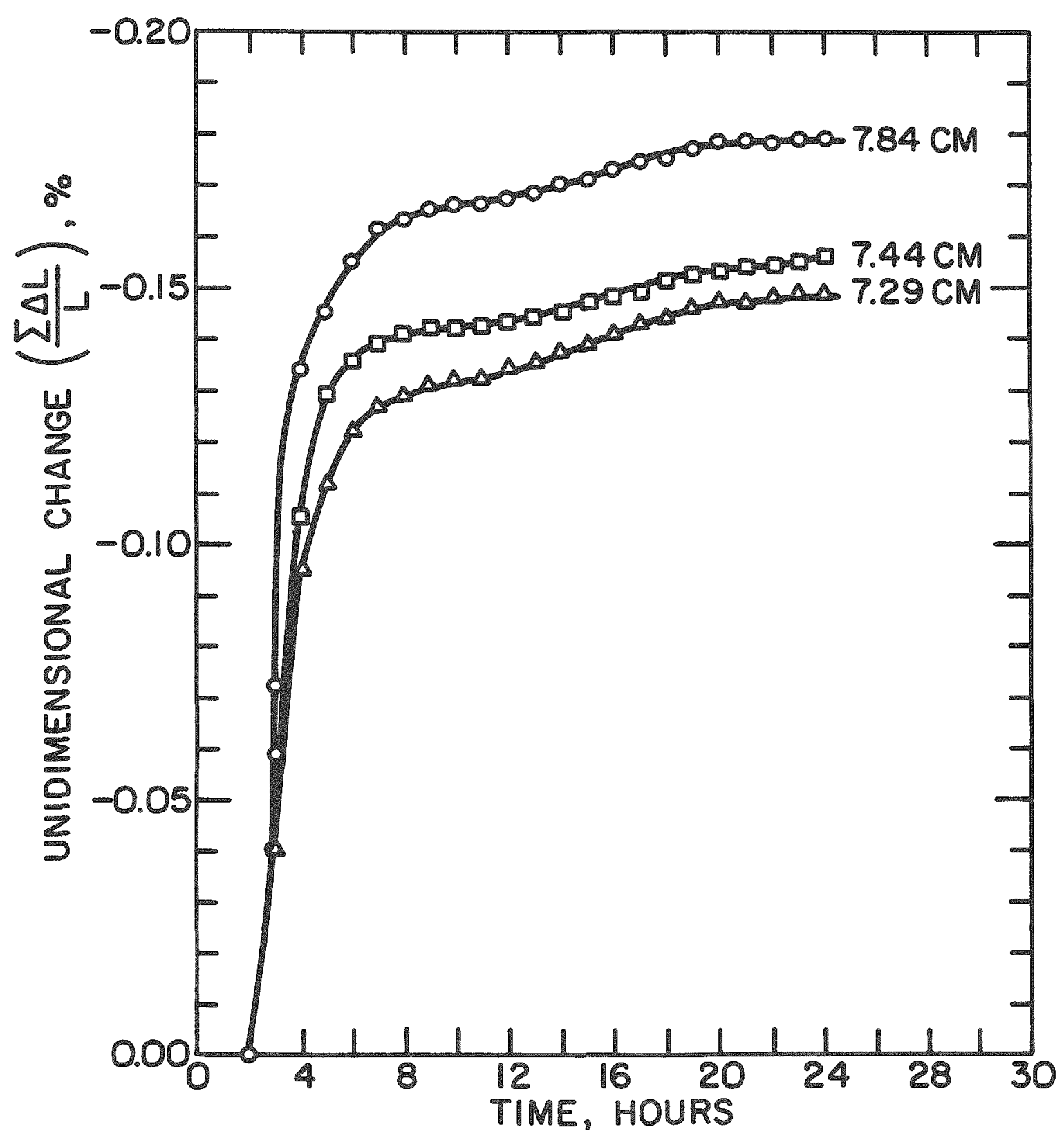

Figure 3.2.3. Unidimensional change of mixture $81-111$ as a function of sample length. 


\subsubsection{Discussion}

Overall behavior of the mixtures presented in this section are satisfactory. Permeability values are very low, nearly always in the $10^{-8}$ darcy $\left(10^{-11} \mathrm{~cm} \mathrm{sec}^{-1}\right)$ range. Consequently, any apparent increases due to expansion of the "gel" related mechanism particular to the silica-fume-substituted cements do not seem to be of consequence. In addition, the use of these mixtures usually will involve restraint of borehole or shaft walls and effects related to expansion will serve to enhance the bond between rock and seal material. Thus, some expansion is deemed desirable. On the short term, the fumed cements or slag cements tend to give the highest compressive strengths.

A model of high-lime fly ash hydration based on the foregoing data as well as data by Scheetz et a1. (1981a) and Grutzeck et al. (1981a) was presented by Grutzeck et al. (1981b). Basically, composition of the paste seems to play a relatively minor role in the hydration of these fly ash spheres. Hydration appears to begin at the surface of the glass sphere and progress inward, leaving in its wake a network of radiating bundles of fibrous C-S-H. Thickness of the glass sphere, age of the honey-comb network, and development of bond strength with time account for observable phenomena.

Reaction rates of $\mathrm{fly}$ ash spheres differ due to varying compositions of glasses. Even though the chemical composition of a mixture is fixed, the composition of species in solution and crystals present in the matrix may vary as a function of time. Finally, should a fly ash sphere be completely surrounded by calcium hydroxide, interaction will be inhibited. Water will be excluded except due to very slow diffusion, resulting in insignificant hydration.

The mechanism of slag hydration is not fully understood, but the effects of temperature on its activation and development of properties of granulated slagcement mixtures has been explained (Roy and Idorn, 1982; Wu et a1., 1982; Parker and Roy, 1982).

Evidence has been presented that silica fumes (including ferrosilicon dusts) are very effective pozzolanic materials, reacting with free $\mathrm{Ca}(\mathrm{OH})_{2}$ to minimize or eliminate it, at temperatures from room to $90^{\circ} \mathrm{C}$. Some irregular compressive strength variations have been observed by others when fume or dust substitutions above $10 \mathrm{wt} \%$ have been made, and recent work at this laboratory has also found this to be the case. However, other properties such as microhardness or permeability show no such effects. Nevertheless, current mixture using fume substitutIng for cenent are now formulated to keep the content below 10 wt \%. Strength 
gain, reduction of free $\mathrm{Ca}(\mathrm{OH})_{2}$, densification, and low permeabilities are routinely expected when small silica fume contents are incorporated.

\subsection{EXPLORATORY MIXTURES}

\subsubsection{Introduction}

This section presents information on early mixtures or experimental mixtures used to explore reactivity of silica fumes in the non-plasticized state. The data are of ten preliminary in nature; however, the results obtained acted as foundation for runs already reported upon.

\section{3 .2 Viscosity}

The mixture 81-010, which contained cement and sand, was thick and behaved much like the thick pastes discussed previously. Data for mixture 81-010 are given in Table 3.3.1. Most of the older mixtures in this section were prepared before a viscometer was available, and no in-depth study of rheology was completed. However, mixtures were formulated with as little water as possible and tended to have the consistency of thick pastes.

\subsubsection{Formulations}

The mixtures described in this section were formulated to investigate the effects of replacing approximately $30-50$ wt \% of the cement portion of the mixture with various silica-rich materials, such as $\mathrm{C}-109$ sand (81-010), class $\mathrm{F}$ fly ash (79-010,79-020 and 79-030), silica fume (79-060 and 80-010), and class C fly ash and/or slag (79-040 and 79-050).

The formulations of the mixtures are given in Table 3.3.2. Composition of starting materials are given in Appendix A. Mixture 80-010 was formulated as a reference for comparing other mixtures. It is a sandy, thick grout, containing 70 wt \% class H cement and 30 wt \% ASTM C 109 sand. It may be compared with many of the mixtures discussed in the report in which approximately $30-50 \mathrm{wt} \%$ of the mixture consists of sand with various reactive additives in part substituting for the cement. The composition of the sand was assumed to be essentially pure $\mathrm{SiO}_{2}$.

Mixtures 79-010,79-020 and 79-030 each contain class $C$ cement and a class $F$ fly ash. The fly ash is rich in $\mathrm{SiO}_{2}$ and $\mathrm{Al}_{2} \mathrm{O}_{3}$ and relatively poor in CaO. As a result, the calcium oxide to silica molar ratio of the various mixtures varies from approximately $1.25(79-020)$ to $0.83(79-030)$ as more fly ash is added to the 
Table 3.3.1. Apparent viscosity $\left(\mathrm{cP}^{\dagger}\right)^{\dagger}$ at $132 \mathrm{sec}^{-1}$ shear of exploratory mixture 81-010.

\begin{tabular}{lllllll}
\hline & \multicolumn{6}{c}{ time, hrs } \\
\cline { 2 - 7 } mixture & 0.11 & 0.5 & 1.0 & 2.0 & 2.5 & 5.0 \\
\hline $81-010$ & 1233 & 1530 & 1784 & 1873 & \\
\hline * contains sand. & & & & $\dagger_{1} \mathrm{cP}=\mathrm{mPa} . \mathrm{s}$.
\end{tabular}

Table 3.3.2. Formulation of exploratory mixes.

\begin{tabular}{|c|c|c|c|c|c|c|c|c|c|}
\hline & \multirow{2}{*}{ code no. } & \multicolumn{8}{|c|}{ mixture } \\
\hline & & $81-010$ & $79-010$ & $79-020$ & $79-030$ & $79-060$ & $80-010$ & $79-050$ & $79-040$ \\
\hline class $\mathrm{H}$ cement & $\mathrm{H}-4, \mathrm{H}-7, \mathrm{H}-8$ & 100.0 & -- & -- & -- & -- & 69.4 & -- & -- \\
\hline class $\mathrm{C}$ cement & $\mathrm{C}-2, \mathrm{C}-5$ & - & 54.35 & 61.44 & 45.05 & 69.4 & -- & 35.15 & 51.0 \\
\hline fly ash & B3 & - & 45.65 & 38.56 & 54.95 & - & -- & - & 19.6 \\
\hline ferrosilicon dust & B17 & -- & -- & - & -- & 15.3 & 15.3 & -- & -- \\
\hline slag & B19 & -- & -- & -- & -- & - & - & 35.15 & 29.4 \\
\hline Min-u-sil & $B 5, B 7, B 23$ & - & $-\infty$ & -- & -- & 15.3 & 15.3 & 29.70 & -- \\
\hline sand C 109 & $\mathrm{C} 15$ & 42.86 & -- & -- & -- & -- & -- & -- & -- \\
\hline Mighty $\mathrm{C} 150$ & A3 & 1.18 & - & -- & -- & -- & - & -- & -- \\
\hline water & E01 & 26.11 & 33.0 & 33.04 & 33.0 & 37.5 & 32.5 & 45.00 & 35.0 \\
\hline$w / c$ & & 0.26 & 0.61 & 0.54 & 0.73 & 0.54 & 0.47 & 1.28 & 0.69 \\
\hline w/reactive solids & & 0.26 & 0.33 & 0.33 & 0.33 & 0.38 & 0.32 & 0.45 & 0.35 \\
\hline
\end{tabular}


mixture. This study was made to illustrate the effects of replacement of relatively large amounts of cement by fly ash.

Mixtures 79-060 and 80-010 were formulated from a class $\mathrm{C}$ and a class $\mathrm{H}$ cement, respectively. Both contained equivalent amounts of cement and a 50:50 mixture of ferrosilicon dust and $30 \mu \mathrm{m}$ quartz. Since these did not contain a high range water reducer, the water required to formulate an equally consistent paste varied from $37.5 \mathrm{~g}$ for the finer class $\mathrm{C}$ cement to $32.5 \mathrm{~g}$ for the coarser class $H$ cement. The results of these experiments gave insight into the effect of adding $15.3 \mathrm{wt} \%$ ferrosilicon dust to a paste (as compared to the sandy grout discussed earlier), the effect of reducing the w/c ratio, and the effect of changing the cement reactivity by changing the particle size of the cement.

Rather than risk volume instability from excessive silica fume additions, the silica replacement of some of the cements were made by a 50:50 mixture of fume and $30 \mu \mathrm{m}$ quartz. The results have shown that even $15.3 \mathrm{wt} \%$ may have been too much.

Mixture 79-040 contained class $C$ cement blended with slag and a class F fly ash. It contained a relatively large proportion of slag and a moderate amount of $\mathrm{f} 1 \mathrm{y}$ ash. Of the replacements, the slag was expected to react fastest, whereas the fly ash would be expected to react much more slowly, but contribute to strength development over the long term.

Blast furnace slag was again used in formulating the mixture (79-050). Because no high-range water reducer was used in this formulation, it has a relatively high water content (w/s ratio) ranging from 0.69 and 0.45 if only the cement and slag, or if all solids, cement, slag and quartz are considered. The mixture is very rich in silica, having a bulk $\mathrm{SiO}_{2}$ content of approximately 55 wt \%. Some lime reduction was anticipated, and as will. be seen in the report, actually occurred.

\section{3 .4 Results}

Compressive Strength, Microhardness and Bulk Density. Compressive strength and bulk density data for all eight mixtures are given in Tables 3.3.3 and 3.3.4, respectively. Microhardness data are given in Appendix A. Compressive strengths of mixture 81-010 increase with time, reaching values between 69 and $86 \mathrm{MPa}$ in 28 days.

Data for mixtures 79-010, 79-020 and 79-030 represent curing behavior at $90^{\circ} \mathrm{C}$ for each mixture. In addition, data for $27^{\circ}$ and $60^{\circ} \mathrm{C}$ for mixture $79-030$, with the least amount of fly ash substitution, are also given. Relatively high strengths at all temperatures are characteristic of the latter at 90 days. 
Table 3.3.3. Compressive strength of exploratory mixtures (MPa).

\begin{tabular}{|c|c|c|c|c|c|c|c|c|c|}
\hline \multirow{2}{*}{$\begin{array}{c}\text { specimen } \\
\text { age } \\
\text { (days) }\end{array}$} & \multirow{2}{*}{$\begin{array}{l}\text { cure } \\
\text { temp. } \\
\left({ }^{\circ} \mathrm{C}\right)\end{array}$} & \multicolumn{8}{|c|}{ mixture } \\
\hline & & $81-010$ & 79-010 & $79-020$ & $79-030$ & $79-060$ & $80-010$ & $79-050$ & $79-040$ \\
\hline 7 & $\begin{array}{l}27 \\
45 \\
60 \\
90\end{array}$ & $\begin{array}{l}51.0 \\
77.6 \\
54.6 \\
59.5\end{array}$ & & & & $\begin{array}{l}53.4 \\
42.6 \\
46.8 \\
41.9\end{array}$ & $\begin{array}{l}53.1 \\
48.2 \\
40.3 \\
39.6\end{array}$ & $\begin{array}{l}43.2 \\
42.9 \\
44.0 \\
57.4\end{array}$ & $\begin{array}{l}56.4 \\
64.6 \\
65.9 \\
76.9\end{array}$ \\
\hline 14 & $\begin{array}{l}27 \\
45 \\
60 \\
90\end{array}$ & $\begin{array}{l}38.8 \\
36.9 \\
53.4 \\
41.3\end{array}$ & 65.6 & 62.0 & $\begin{array}{l}37.2 \\
52.1 \\
25.3\end{array}$ & $\begin{array}{l}62.6 \\
68.1 \\
70.7 \\
41.5\end{array}$ & $\begin{array}{l}67.4 \\
67.8 \\
46.6 \\
42.1\end{array}$ & $\begin{array}{l}60.4 \\
61.2 \\
62.4 \\
87.3\end{array}$ & $\begin{array}{l}70.8 \\
71.0 \\
87.6 \\
72.3\end{array}$ \\
\hline 28 & $\begin{array}{l}27 \\
45 \\
60 \\
90\end{array}$ & $\begin{array}{l}81.8 \\
74.9 \\
85.9 \\
68.5\end{array}$ & 49.7 & 38.2 & $\begin{array}{l}42.1 \\
57.4 \\
30.3\end{array}$ & $\begin{array}{l}-- \\
66.2 \\
58.9 \\
60.4\end{array}$ & $\begin{array}{l}62.5 \\
72.1 \\
5-.9 \\
68.6\end{array}$ & $\begin{array}{l}68.4 \\
55.3 \\
52.1 \\
88.2\end{array}$ & $\begin{array}{l}64.2 \\
73.1 \\
63.3 \\
79.5\end{array}$ \\
\hline 56 & $\begin{array}{l}27 \\
45 \\
60 \\
90\end{array}$ & & 42.6 & 51.4 & $\begin{array}{l}19.6 \\
51.7 \\
61.8\end{array}$ & & & & \\
\hline 90 & $\begin{array}{l}27 \\
45 \\
60 \\
90\end{array}$ & & 81.3 & 59.6 & $\begin{array}{l}42.4 \\
65.9 \\
67.3\end{array}$ & & & & \\
\hline 180 & $\begin{array}{l}27 \\
45 \\
60 \\
90\end{array}$ & & 48.8 & 50.0 & $\begin{array}{l}62.3 \\
65.3 \\
34.8\end{array}$ & & & & \\
\hline
\end{tabular}


Table 3.3.4. Bulk density of exploratory mixtures.

\begin{tabular}{|c|c|c|c|c|c|c|c|c|c|}
\hline \multirow{2}{*}{$\begin{array}{c}\text { specimen } \\
\text { age } \\
\text { (days) }\end{array}$} & \multirow{2}{*}{$\begin{array}{l}\text { cure } \\
\text { temp. } \\
\left({ }^{\circ} \mathrm{C}\right)\end{array}$} & \multicolumn{8}{|c|}{ mixture } \\
\hline & & $81-010$ & $79-010$ & $79-020$ & $79-030$ & $79-060$ & $80-010$ & $79-050$ & $79-040$ \\
\hline 7 & $\begin{array}{l}27 \\
45 \\
60 \\
90\end{array}$ & $\begin{array}{l}2.07 \\
2.04 \\
2.06 \\
2.06\end{array}$ & & & & $\begin{array}{l}1.82 \\
1.83 \\
1.77 \\
1.70\end{array}$ & $\begin{array}{l}1.79 \\
1.81 \\
1.84 \\
1.74\end{array}$ & $\begin{array}{l}1.80 \\
1.81 \\
1.78 \\
1.78\end{array}$ & $\begin{array}{l}2.01 \\
2.03 \\
2.08 \\
2.01\end{array}$ \\
\hline 14 & $\begin{array}{l}27 \\
45 \\
60 \\
90\end{array}$ & $\begin{array}{l}2.10 \\
2.06 \\
2.07 \\
2.09\end{array}$ & 1.83 & 1.81 & $\begin{array}{l}1.89 \\
1.89 \\
1.84\end{array}$ & $\begin{array}{l}1.84 \\
1.93 \\
1.85 \\
1.79\end{array}$ & $\begin{array}{l}1.76 \\
1.85 \\
1.83 \\
1.88\end{array}$ & $\begin{array}{l}1.86 \\
1.86 \\
1.88 \\
1.84\end{array}$ & $\begin{array}{l}1.95 \\
1.94 \\
1.98 \\
1.93\end{array}$ \\
\hline 28 & $\begin{array}{l}27 \\
45 \\
60 \\
90\end{array}$ & $\begin{array}{l}2.13 \\
2.13 \\
2.01 \\
2.14\end{array}$ & 1.99 & 2.04 & $\begin{array}{l}1.90 \\
1.89 \\
1.82\end{array}$ & $\begin{array}{l}1.75 \\
1.73 \\
1.70 \\
1.78\end{array}$ & $\begin{array}{l}1.83 \\
1.83 \\
1.84 \\
1.89\end{array}$ & $\begin{array}{l}1.83 \\
1.82 \\
1.84 \\
1.81\end{array}$ & $\begin{array}{l}2.00 \\
2.01 \\
1.97 \\
1.99\end{array}$ \\
\hline 56 & $\begin{array}{l}27 \\
45 \\
60 \\
90\end{array}$ & & 1.93 & 1.95 & $\begin{array}{l}1.92 \\
1.89 \\
1.87\end{array}$ & & & & \\
\hline 90 & $\begin{array}{l}27 \\
45 \\
60 \\
90\end{array}$ & & 1.99 & 2.01 & $\begin{array}{l}2.04 \\
2.02 \\
1.97\end{array}$ & & & & \\
\hline 180 & $\begin{array}{l}27 \\
45 \\
60 \\
90\end{array}$ & & 1.91 & 1.89 & $\begin{array}{l}1.52 \\
1.53 \\
1.55\end{array}$ & & & & \\
\hline
\end{tabular}


Contrary to conventionally accepted correlations of compressive strength to w/c ratio, mixtures $79-060$ and 80-010 attain similar compressive strengths independent of water content. Apparently, the gain in strength due to the reduction in water due to the coarser grind of the class $\mathrm{H}$ cement balances the corresponding 1oss in strength of the less reactive, lower surface area class H cement. All sets have reasonably high strengths at 28 days.

The compressive strength and microhardness data for mixture 79-050 tend to show a clustering of the $27^{\circ}, 45^{\circ}$, and $60^{\circ} \mathrm{C}$ data in a distinct grouping separate from the $90^{\circ} \mathrm{C}$ data. In both compressive strength and microhardness, the $90^{\circ} \mathrm{C}$ data prove to be the stronger. Apparently, this mixture would benefit from the addition of superplasticizer. Mixtures containing silica fume and superplasticizer already discussed tend to bear this out.

The mixture 79-040, comparable to other slag-containing mixtures, shows relatively high strengths at 7 days, particularly for the $45^{\circ}, 60^{\circ}$. and $90^{\circ} \mathrm{C}$ samples.

Permeability. Since most samples were quite exploratory, no routine permeability measurements were made. The two exceptions were mixtures 81-010 and 80-010. Data are presented in Table 3.3.5 for 81-010 and 80-010. Values for 81-010 were calculated to be less than $10^{-8}$ darcys at all times and temperatures with the exception of 14 and 28 days at $90^{\circ} \mathrm{C}$. A very sma11 flow was observed at these times and temperature. This suggests that curing at temperatures above $90^{\circ} \mathrm{C}$ tend to change the hydration process somewhat, often causing larger pore sizes and perhaps greater associated permeability. Parker and Roy (1982) have shown this phenomenon for cements, particularly at higher w/c ratios. Data for mixture 80-010 reflect these same general findings.

X-ray Diffraction. Data for mixture 81-010 are presented in Table 3.3.6. Mixture 81-010 shows a normal progression of hydration. $\mathrm{Ca}(\mathrm{OH})_{2}$ is present at all times and temperatures. Some ettringite is formed early, being replaced by AFm phases at later times.

$\mathrm{X}$-ray diffraction data for mixtures $79-010,79-020$ and 79-030 are given in Table 3.3.7. Ettringite is present at all times at $27^{\circ} \mathrm{C}$ in mixture $79-030$. It is also present at $60^{\circ} \mathrm{C}$ up to 28 days, after which its presence or absence is sporadic. The low-1ime fly ash used in mixtures 79-010, 79-020 and 79-030 is reactive at higher temperatures, since $\mathrm{Ca}(\mathrm{OH})_{2}$ is absent at $90^{\circ} \mathrm{C}$ at all times, and at $60^{\circ} \mathrm{C}$ at 180 days.

X-ray diffraction data for mixtures 79-060 and 80-010 are given in Table 
Table 3.3.5. Water permeabilitv data for mixtures $81-010$ and $80-010$ $\left(\right.$ darcy $\left.\cong \mu m^{2}\right)$.

\begin{tabular}{llccc}
\hline \multirow{2}{*}{$\begin{array}{c}\text { cure } \\
\text { time }\end{array}$} & temperature, ${ }^{\circ} \mathrm{C}$ \\
\cline { 2 - 4 } & $27^{\circ}$ & $45^{\circ}$ & $60^{\circ}$ & $90^{\circ}$ \\
\hline
\end{tabular}

81-010: class $\mathrm{H}$ cement + sand

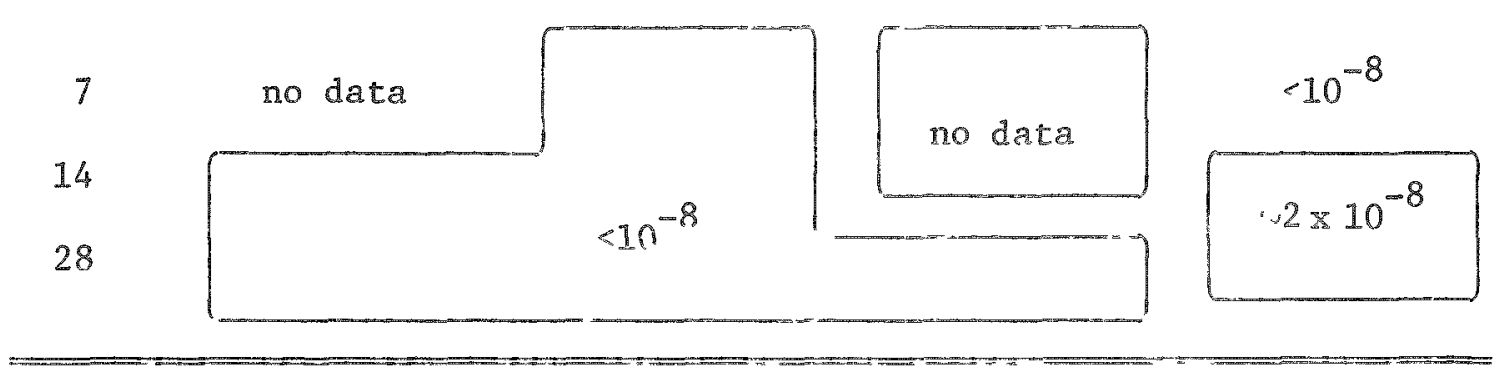

80-010: class H cement + ferrodust + quartz

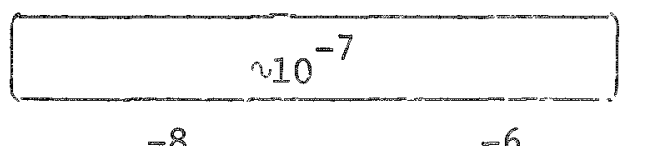

$$
10^{-6}
$$

failure*

14

$$
<10^{-8}
$$

$10^{-8}$

$010^{-4}$

28

missing data

Failure*

*These failures may be related to the relatively low compressive strengths of these samples due to their relatively high w/s ratio. 
Table 3.3.6. X-ray diffraction data for sandy grout 81-010.

\begin{tabular}{|c|c|c|c|c|}
\hline \multicolumn{5}{|c|}{ 81-010: class H cement + sand } \\
\hline \multirow{2}{*}{$\begin{array}{l}\text { cure } \\
\text { time } \\
\text { (days) }\end{array}$} & \multicolumn{4}{|c|}{ temperature, ${ }^{\circ} \mathrm{C}$} \\
\hline & $27^{\circ}$ & $45^{\circ}$ & $60^{\circ}$ & $90^{\circ}$ \\
\hline 7 & \multicolumn{2}{|c|}{$\begin{array}{c}\mathrm{Ca}(\mathrm{OH})_{2} \\
\text { residual cement } \\
\text { quartz } \\
\text { tr. ettringite }\end{array}$} & $\begin{array}{c}\mathrm{Ca}(\mathrm{OH})_{2} \\
\text { residual cement } \\
\text { quartz } \\
\text { tr.alum-hydxate }\end{array}$ & \\
\hline 14 & $\begin{array}{c}\mathrm{Ca}(\mathrm{OH})_{2} \\
\text { residual cement } \\
\text { quartz } \\
\mathrm{C}-\mathrm{S}-\mathrm{H}\end{array}$ & $\begin{array}{c}\mathrm{Ca}(\mathrm{OH})_{2} \\
\text { residual quartz } \\
\text { quartz } \\
\text { tr. monosulfate } \\
\mathrm{C}-\mathrm{S}-\mathrm{H}\end{array}$ & $\begin{array}{r}\mathrm{Ca} \\
\text { residua } \\
\text { qua } \\
\mathrm{C}-\end{array}$ & \\
\hline
\end{tabular}


Table 3.3.7. X-ray diffraction phase data for samples cured in a saturated $\mathrm{Ca}(\mathrm{OIf})_{2}$ solution.

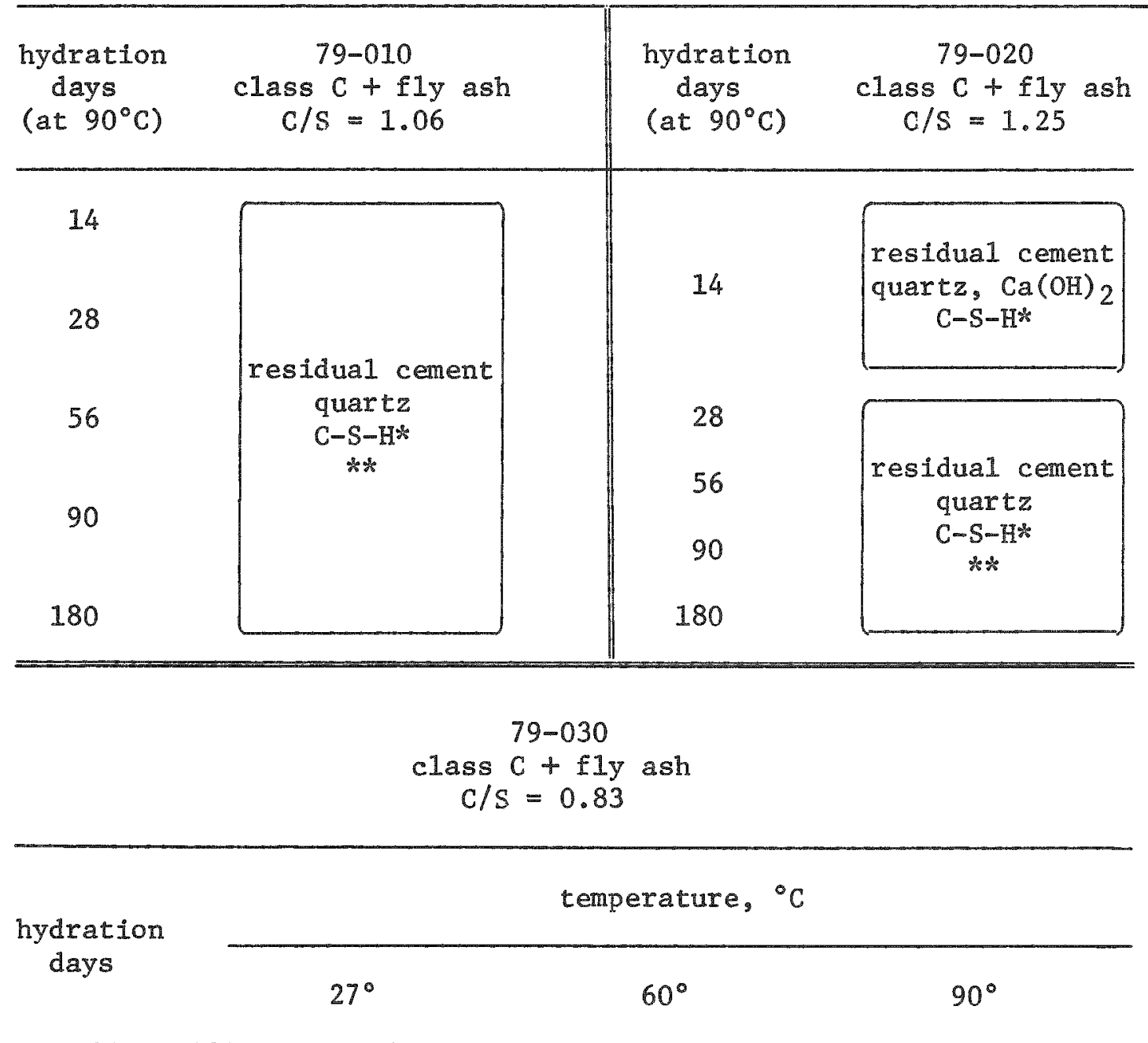

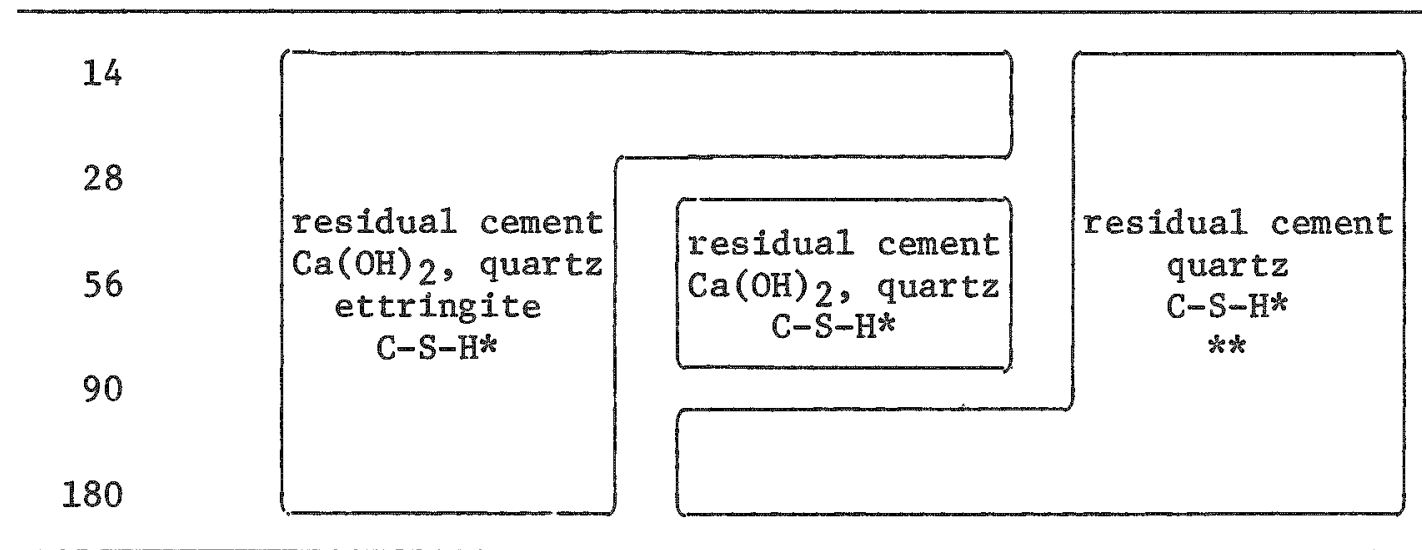

*All samples also contained residual mullite from the ash. **occasionally trace amounts of "ettringite", gypsum or Ca-A1monosulfate hydrate were also detected. The presence or absence of these phases appeared to be random in nature. 
3.3.8. They develop ettringite as one of their earliest aluminate phases. The role of the various aluminous phases and their bearing on the overall stability is yet unclear. Ettringite forms rather quickly and is often converted to monosulfoaluminate depending upon the total sulfate content, temperature and other factors.

X-ray diffraction data for mixture 79-050 and 79-040 are given in Table 3.3.9. These data show that the hydration of these pastes progresses normally. Some residual cement is present throughout, although of reduced magnitude with abundant C-S-H development at nearly all ages. In mixture 79-050, ettringite and calcium monosulfoaluminate are present at early ages and low temperatures. Free $\mathrm{Ca}(\mathrm{OH})_{2}$ is absent at $60^{\circ} \mathrm{C}$ and higher temperatures at 28 days, and absent at $90^{\circ} \mathrm{C}$ at al1 times $(7,14$, and 28 days). This behavior is probably explained by the slag reacting with excess $\mathrm{Ca}(\mathrm{OH})_{2}$ to form additional $\mathrm{C}-\mathrm{S}-\mathrm{H}$ and also by partial reaction of lime with quartz.

The presence of the class $F$ fly ash was not very effective in reducing free $\mathrm{Ca}(\mathrm{OH})_{2}$ in mixture $79-040$ at all times up to 28 days. The $x$-ray determined phases present at all temperatures are $\mathrm{Ca}(\mathrm{OH})_{2}$, residual cement, quartz (from the fly ash), and $\mathrm{C}-\mathrm{S}-\mathrm{H}$.

SEM Studies. Representative SEM photographic images for mixture 81-010 are given in Figures 3.3 .1 to 3.3.3. An interesting observation was that the sand, which was assumed to be non-reactive, did show some reaction, confined to the surfaces of the sand grains. Because of their large size, however, the magnitude of the reaction is limited. Figure 3.3.1 depicts the starting material sand. It has been ultrasonically washed in water and shows characteristically smooth rounded surface features. Chemically, it was essentially pure $\mathrm{SiO}_{2}$. Figure 3.3 .2 gives images of samples of the sandy grout (81-010) hydrated for 7 days at $45^{\circ} \mathrm{C}$ ( $v$ iew a), $60^{\circ} \mathrm{C}$ (views $\mathrm{b}, \mathrm{c}$, and $\mathrm{d}$ ), and $90^{\circ} \mathrm{C}$ (views $\mathrm{e}$ and $\mathrm{f}$ ). View (a) is representative of the type of $\mathrm{C}-\mathrm{S}-\mathrm{H}$ forming in the paste matrix at 7 days. It is typical of all temperatures. The chemistry of this material is dominantly $\mathrm{Ca}$ with lesser Si and minor $\mathrm{K}$. Views (b) through (d) represent a partially encrused sand grain (a), a close-up of the sand grain surface (b) whose chemistry is predominantly Si with traces of $\mathrm{Ca}$, and a close-up of the $\mathrm{C}-\mathrm{S}-\mathrm{H}-$ to-quartz grain interface (c), showing $\mathrm{C}-\mathrm{S}-\mathrm{H}$ development, respectively. The chemistry of the latter $\mathrm{C}-\mathrm{S}-\mathrm{H}$ is dominated by $\mathrm{Ca}$ and $\mathrm{Si}$ with minor $\mathrm{K}$ and trace amounts of Al. Reaction of the sand with the surrounding matrix material is evident. Views (e) and (f) are features typical to the $90^{\circ} \mathrm{C}$ sample. View (e) gives edge detail for a sand grain and shows $\mathrm{C}-\mathrm{S}-\mathrm{H}$ as 
Table 3.3.8. X-rav diffaction data for ferrosilicon dust-substituted cenents.

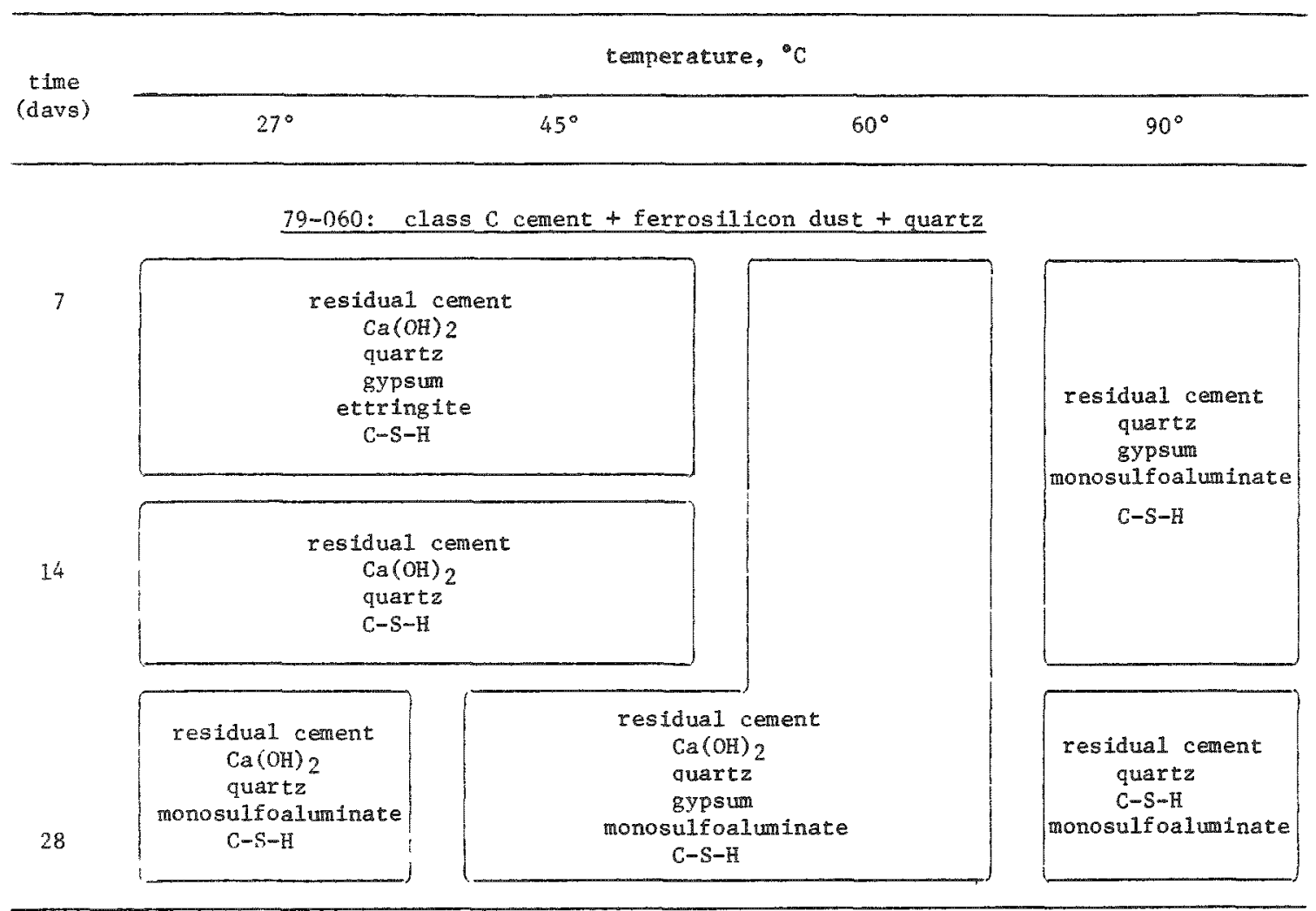

80-010: Class H cement + ferrosilicon dust + quartz

residual centent
$\mathrm{Ca}(\mathrm{OH})_{2}$
quartz
gypsum
ettringite
monosulfoaluminate
$\mathrm{C}-\mathrm{S}-\mathrm{H}$
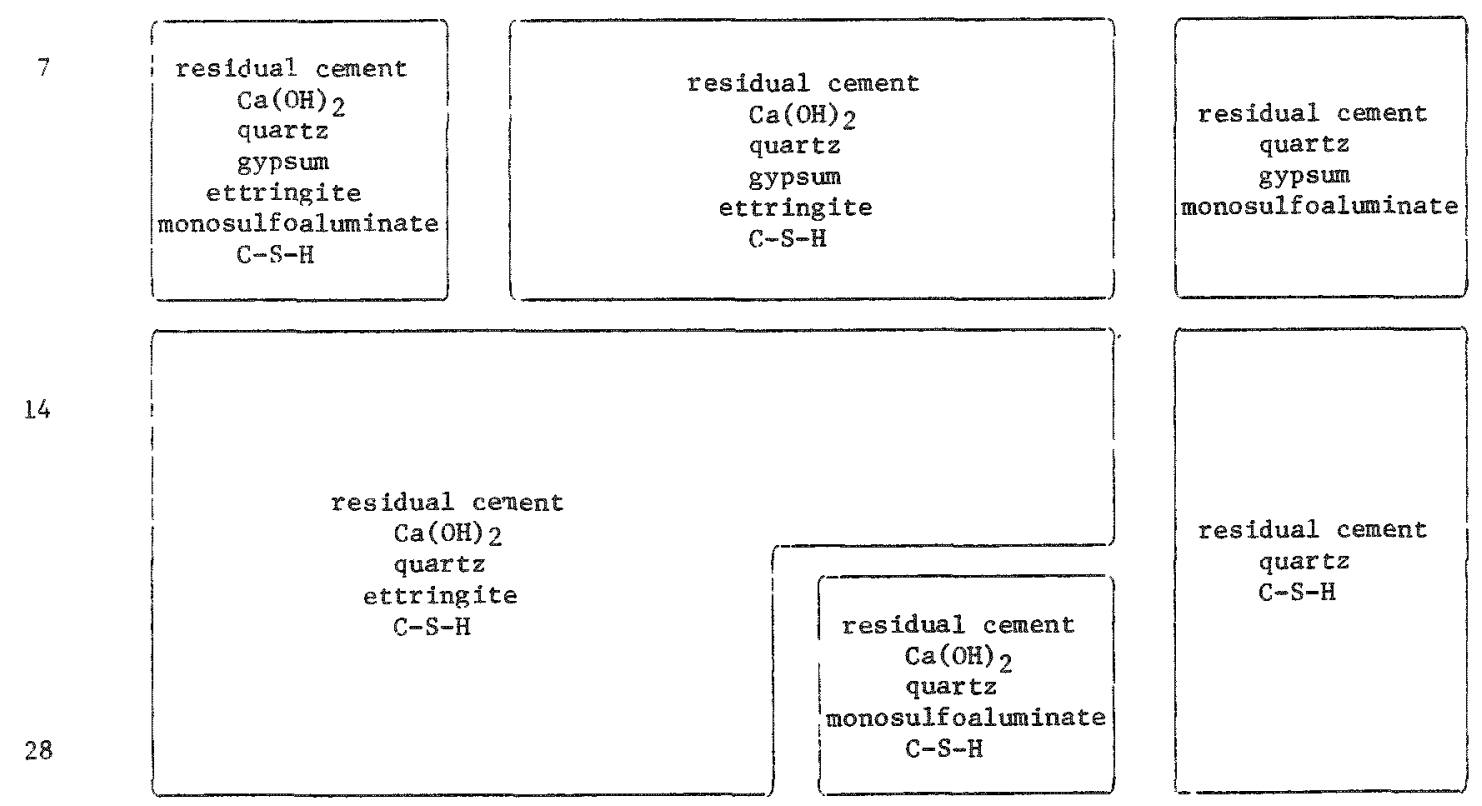


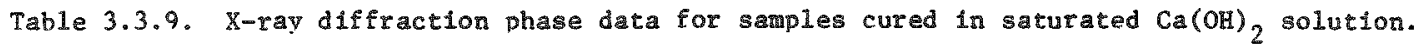

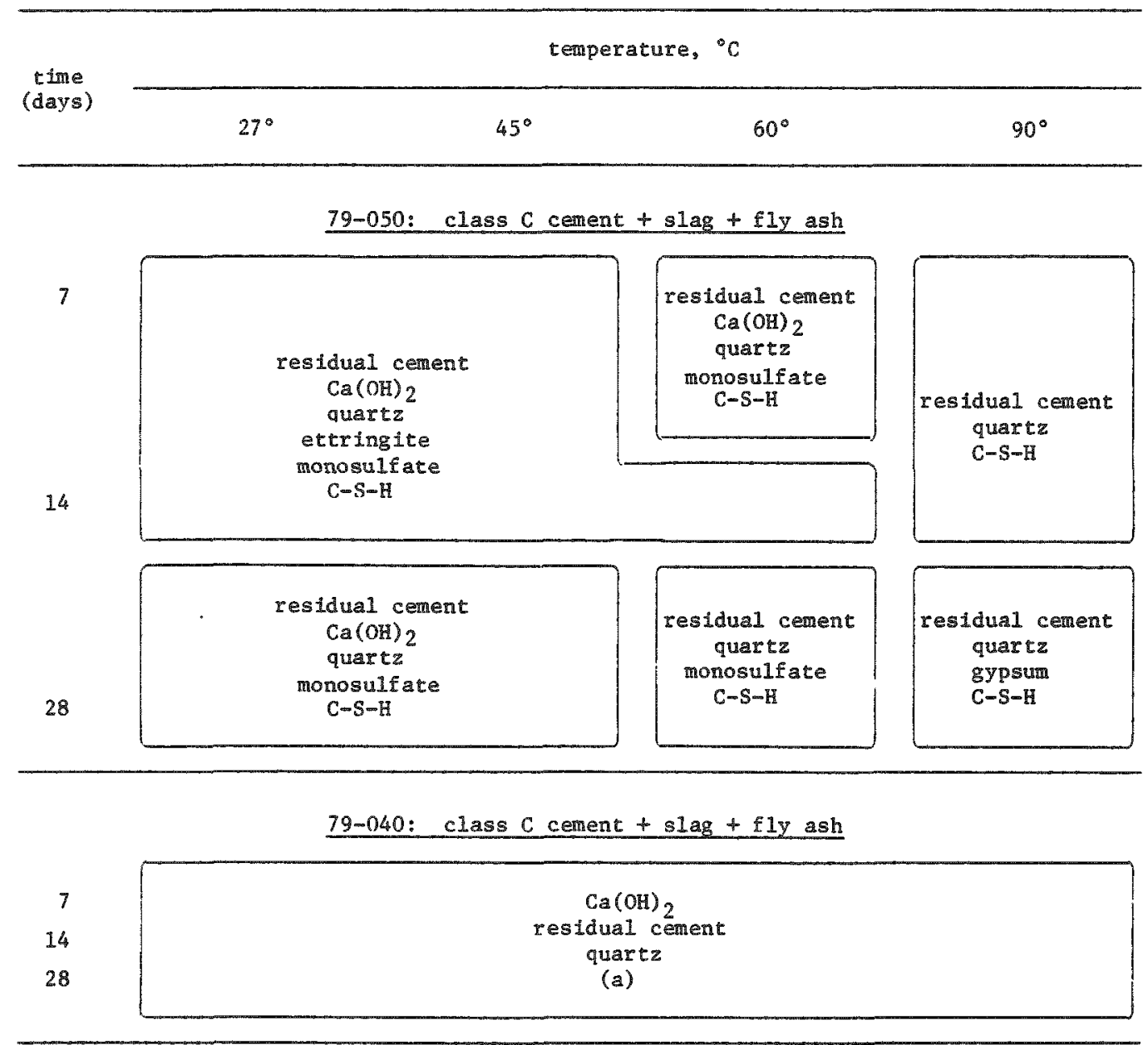

(a) Traces of AFt and AFm at $27^{\circ}$ and $60^{\circ} \mathrm{C}$ at 7 days and at all temperatures at $90^{\circ} \mathrm{C}$ at 14 days. 


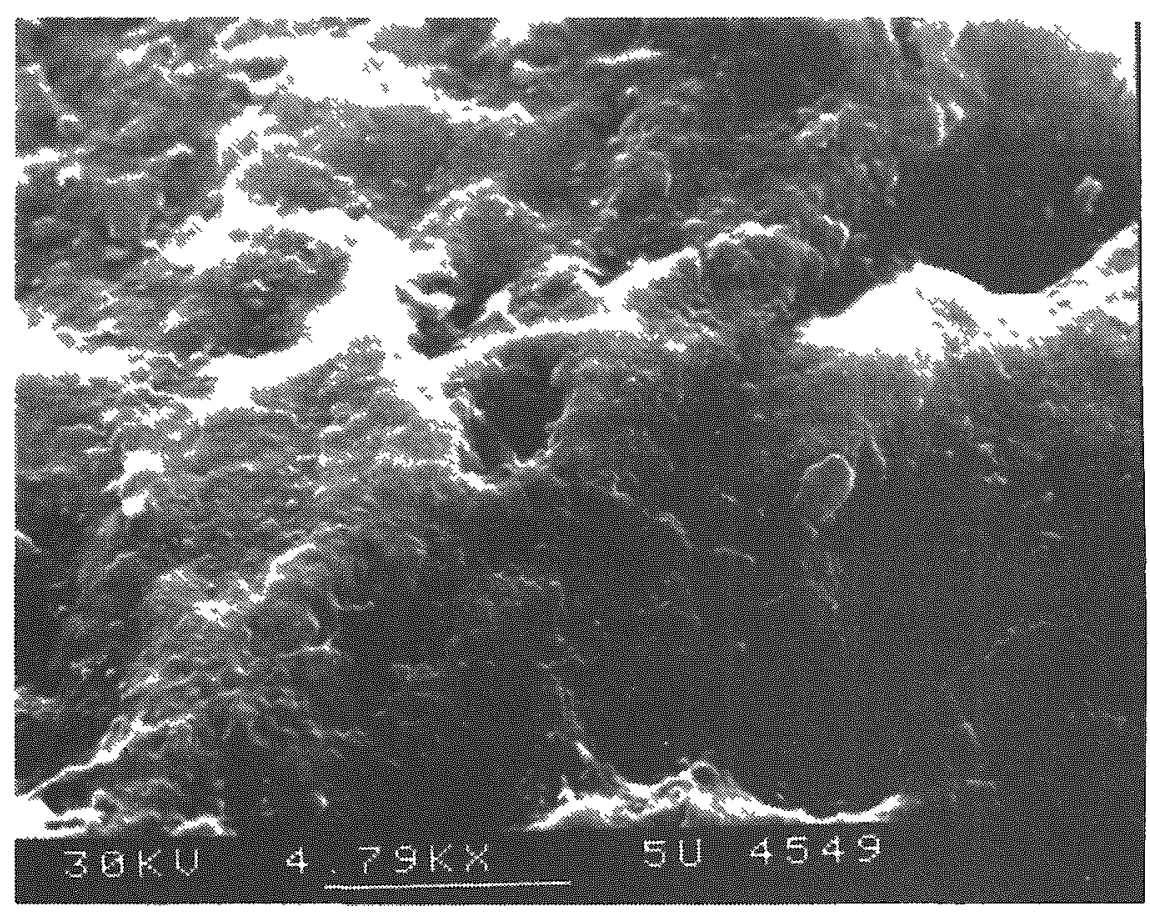

(a)

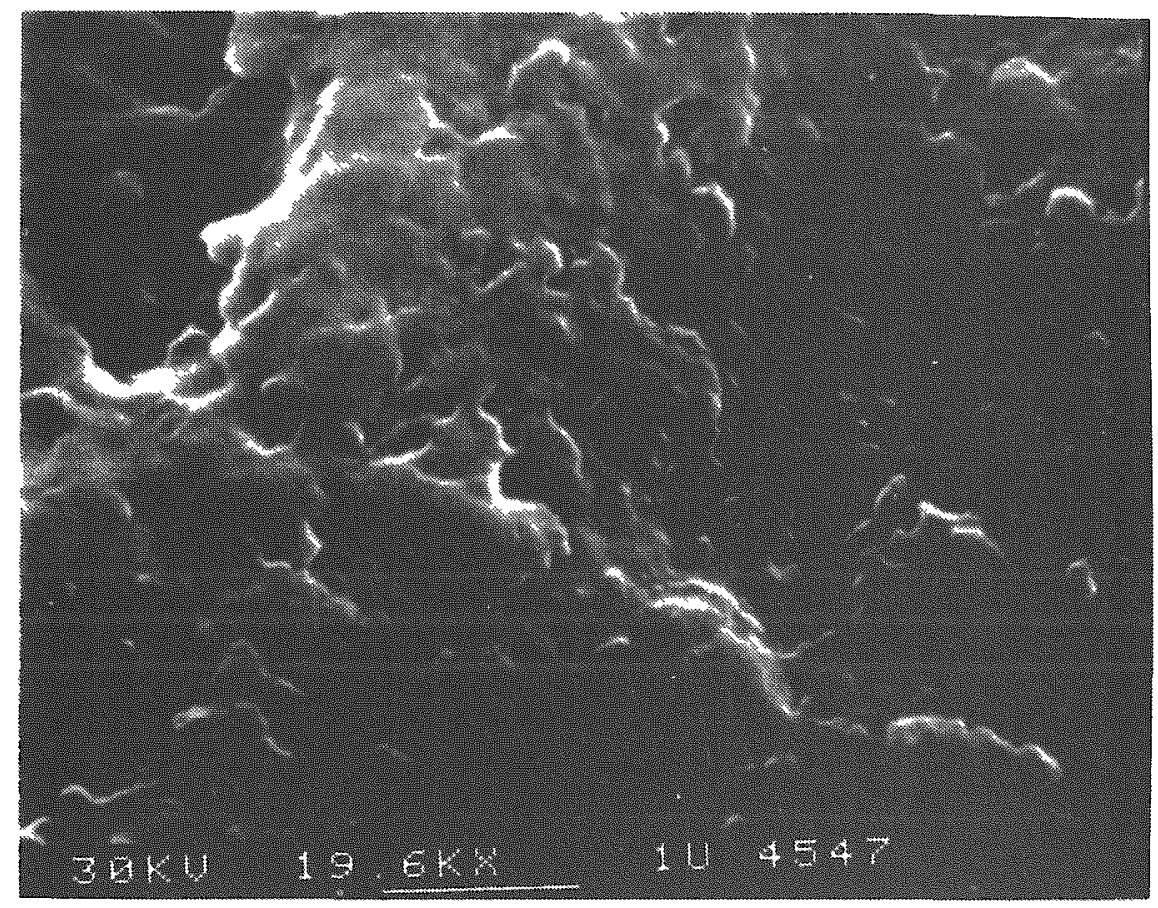

(b)

Figure 3.3.1. SEM images of ASTM C 109 sand. 
Figure 3.3.2. Seven-day hydration of mixture 81-010.

(a) $45^{\circ} \mathrm{C} ; \quad(b, c, d) 60^{\circ} \mathrm{C} ; \quad(e, f) 90^{\circ} \mathrm{C}$.

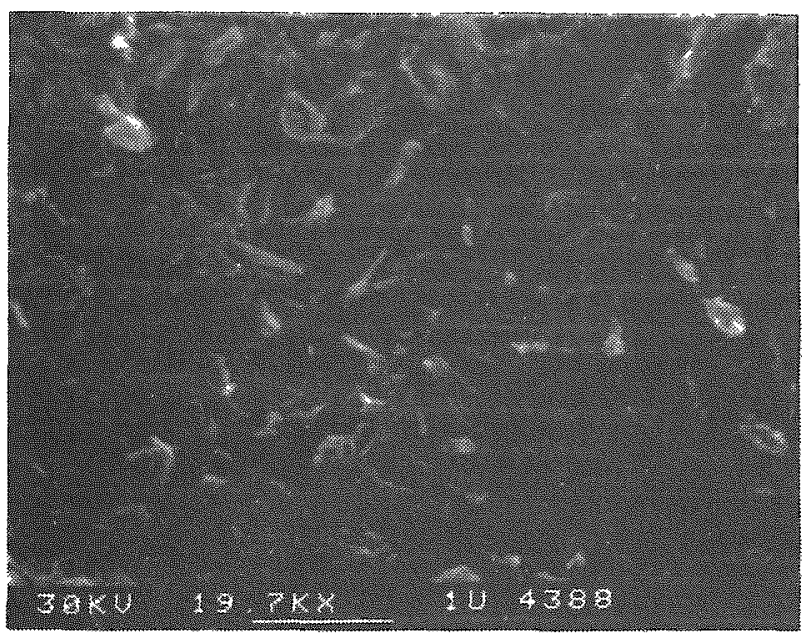

(a)

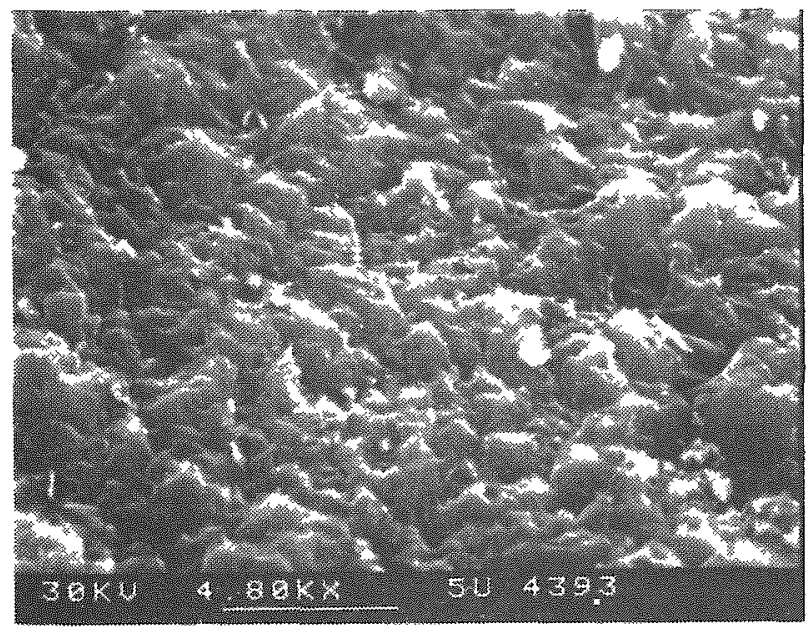

(c)

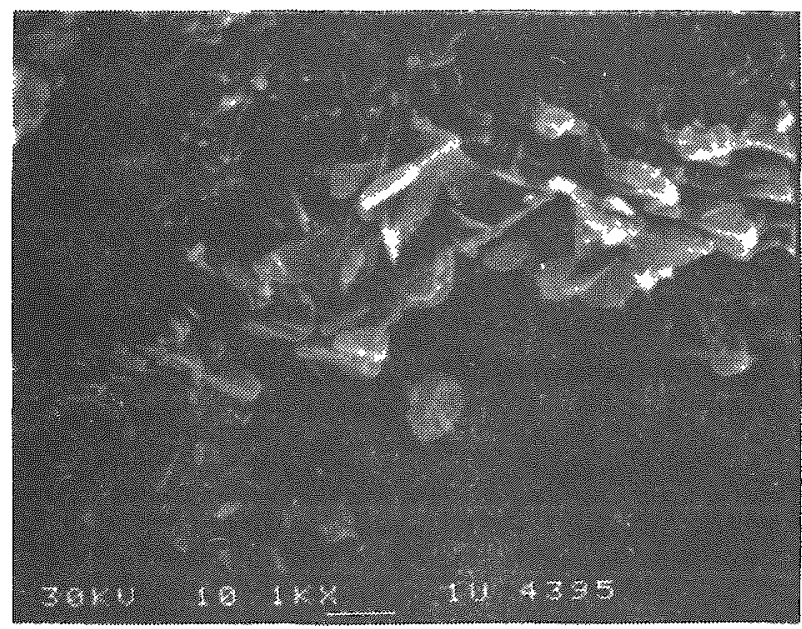

(e)

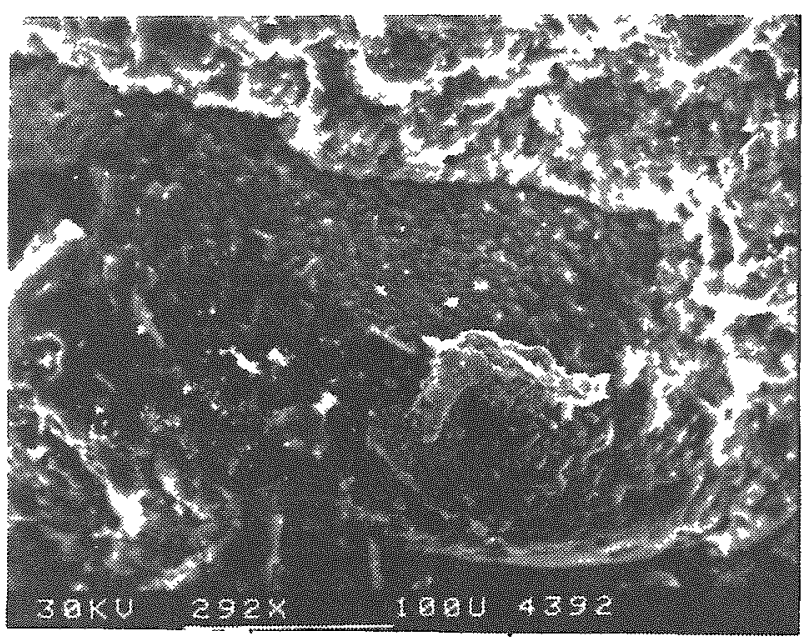

(b)

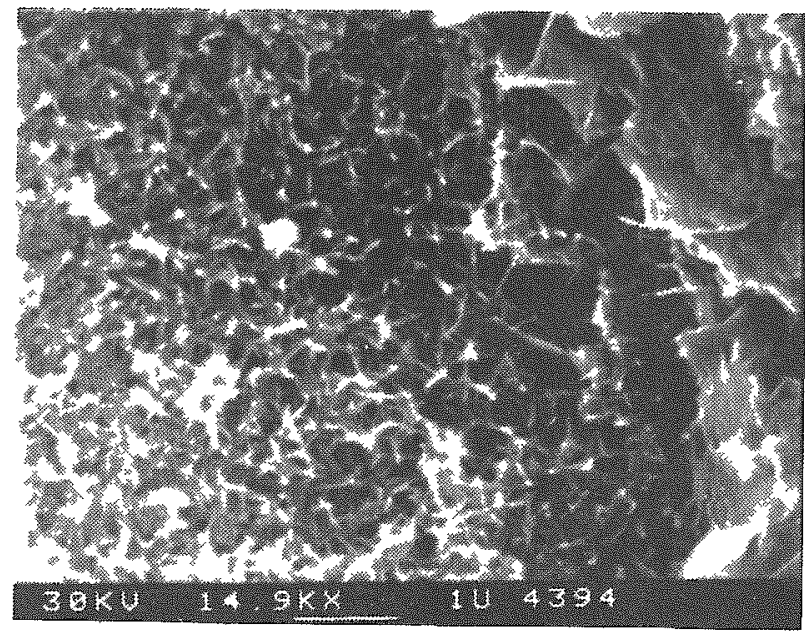

(d)

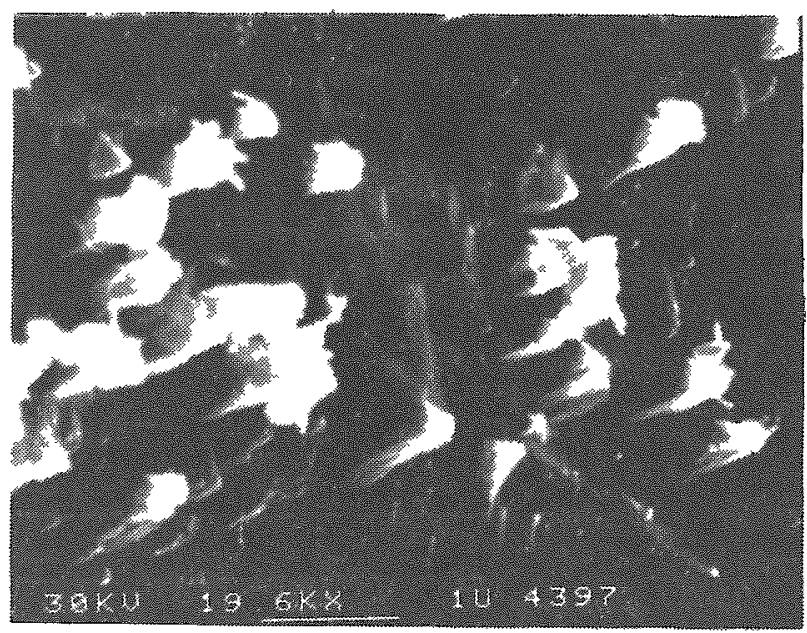

(f) 
well as thin disk-shaped crystals, consisting compositionally of mostly Ca and Si. View (f) is a close-up of a sand particle surface showing etch or solution features and the development of resistant "stack"-like features.

Figure 3.3 .3 gives images of 14-day samples. View (a) represents the surface features developed on a $45^{\circ} \mathrm{C}$ reacted sand grain which has pulled free from the matrix on breakage for SEM examination. The rounded edges of the quartz grain are evident at the edges of the photo, with remant $\mathrm{C}-\mathrm{S}-\mathrm{H}$ adhering to the particle at the middle of the photograph. View (b), at $60^{\circ} \mathrm{C}$, represents an interfacial region between a quartz grain, upper right-hand (URH) corner, and interfacial region, midsection of photo, and an open structured C-S-H material, LLH corner. Calcium content of the interfacial region increases from right to left, from the quartz grain to the $\mathrm{C}-\mathrm{S}-\mathrm{H}$. Views (c) and (d) at $90^{\circ} \mathrm{C}$ are a pair. View (d) is an enlargement of the central portion of view (c) of what appears to be radiating networks of $\mathrm{C}-\mathrm{S}-\mathrm{H}$ surrounding a void from which a particle of some sort has been plucked. Views (e) and (f) at $90^{\circ} \mathrm{C}$ are views of an etched sand grain and a pocket filled with needles (Ca, Si, with traces of $\mathrm{Al}, \mathrm{S}, \mathrm{Fe}$ ) and rounded disk-shaped particles (Ca, Si, Al, S, Fe). Twenty-eight-day features were similar to those a1ready described. General matrix densification was observed.

Representative SEM images for mixtures 79-060 and 80-010 cured for 7 days at $27^{\circ} \mathrm{C}$ are given in Figure 3.3.4, views $(a-c)(79-060)$ and $(d-f)(80-010)$. View (d) is typical of the low magnification microstructure of these samples. The silica fume/quartz matrix is dense, with large angular quartz grains showing. Pockets are filled with ettringite/thaumasite(containing $S i$ ). View (b) is a detailed view apparently of thaumasite (left-hand side) and ettringite or gypsum (right-hand side). Views (a) and (c) are views of matrix showing remnant ferrodust spheres, cemented with fibers and foils of $\mathrm{C}-\mathrm{S}-\mathrm{H}$. In addition, view (e) has monosulfate plates near the center of the photograph. Finally, large remnant ferrodust spheres are shown for each mixture in views (c) and (f). These show possible drying shrinkage effects. If a gel or sol intermediate reaction stage exists for silica fume-substituted cements, as postulated, it is possible that some volume instability and structural weaknesses which could affect compressive strength could result from both gross features as these (views $c$ and $f$ ), or from the same type of behavior on the microscale.

SEM images for 7 -day $27^{\circ} \mathrm{C}$-cured samples of mixture $79-040$ are given in Figure 3.3.5. Views (a-c) show details of AFt-type phases (etcringite) surrounded by $\mathrm{C}-\mathrm{S}-\mathrm{H}$ honey-comb (view a) and typical AFm hexagonal plates (views $\mathrm{b}$ 
Figure 3.3.3. Fourteen-day hydration of mixture 81-010. (a) $45^{\circ} \mathrm{C} ; \quad$ (b) $60^{\circ} \mathrm{C} ; \quad$ (c-f) $90^{\circ} \mathrm{C}$.

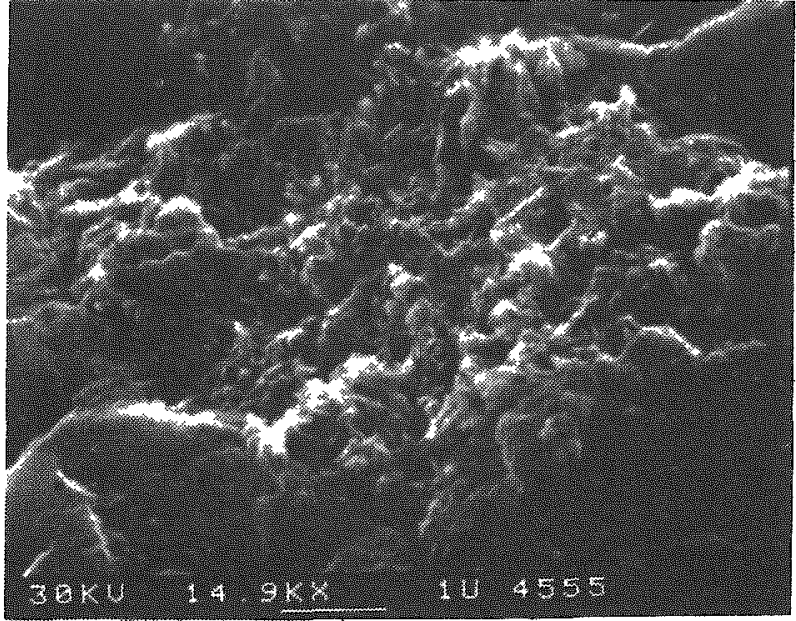

(a)

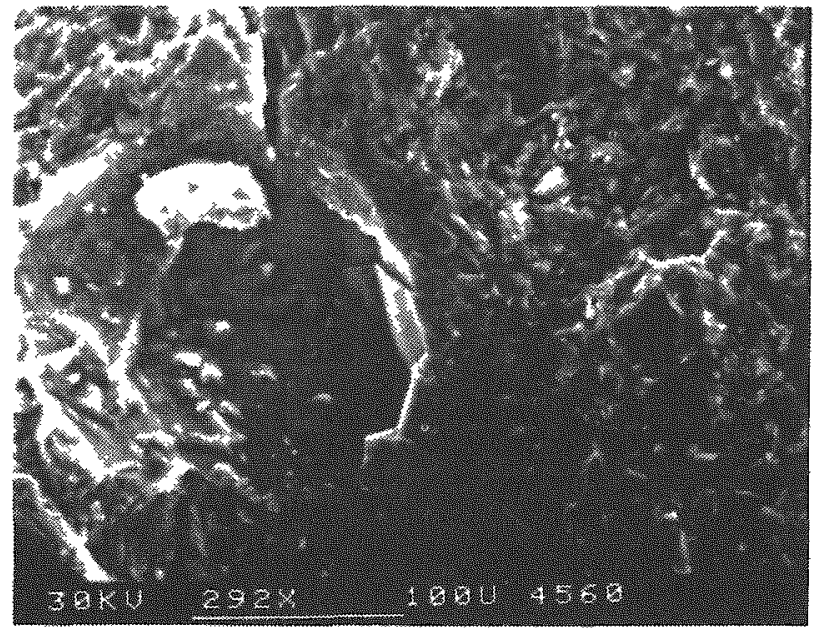

(c)

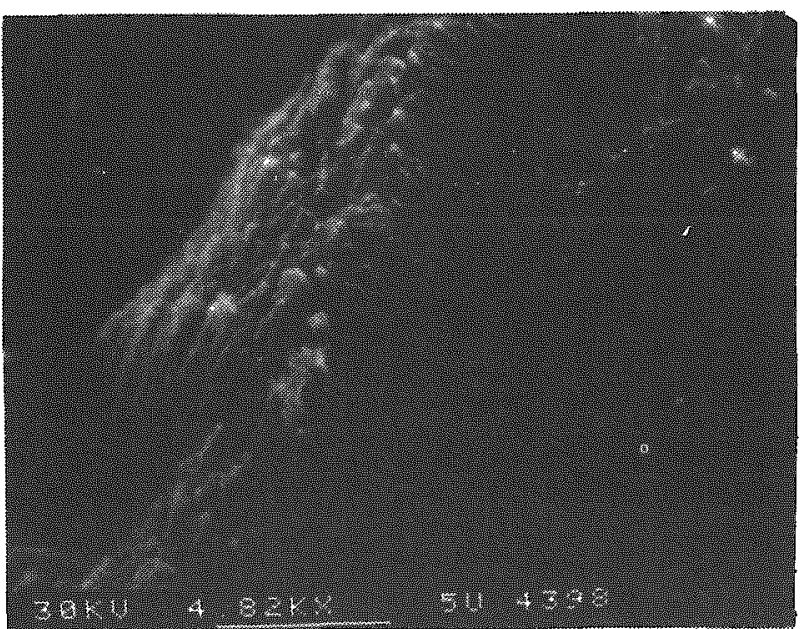

(e)

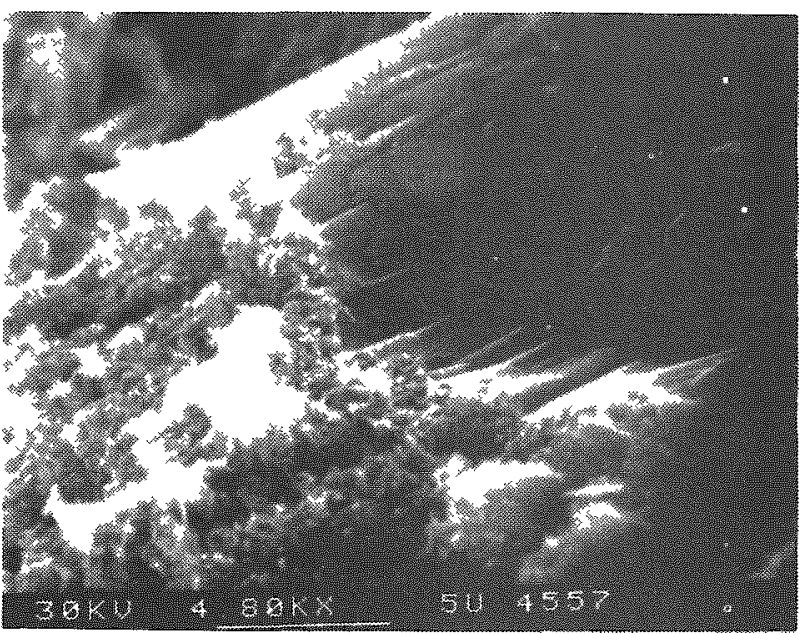

(b)

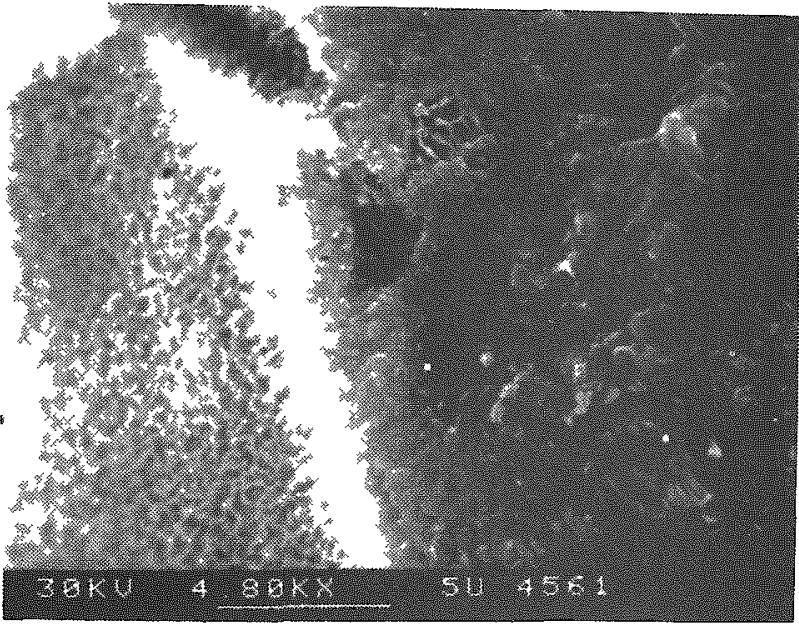

(d)

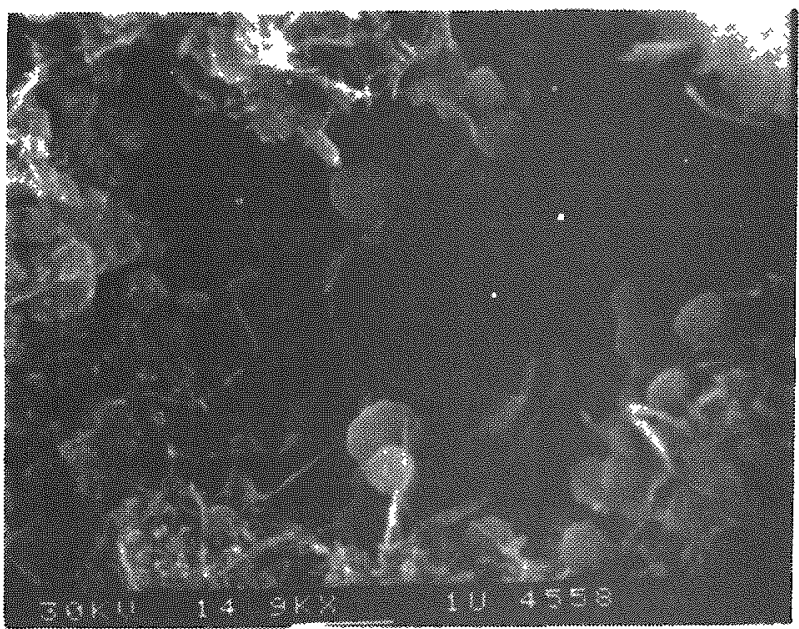

(f) 
Figure 3.3 .4 . SEM images of 7 day, $27^{\circ} \mathrm{C}$ cured samples of mixtures 79-060 (a-c) and 80-010 (d-f).

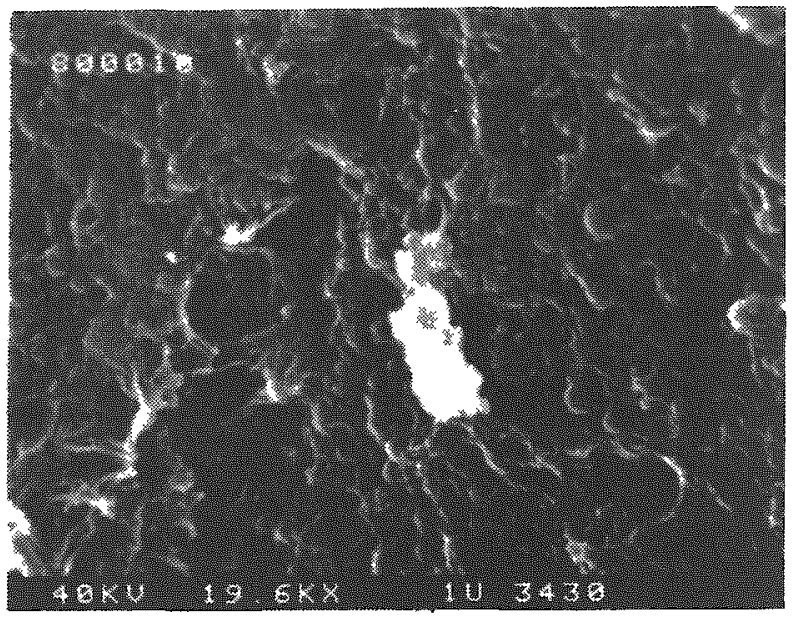

(a)

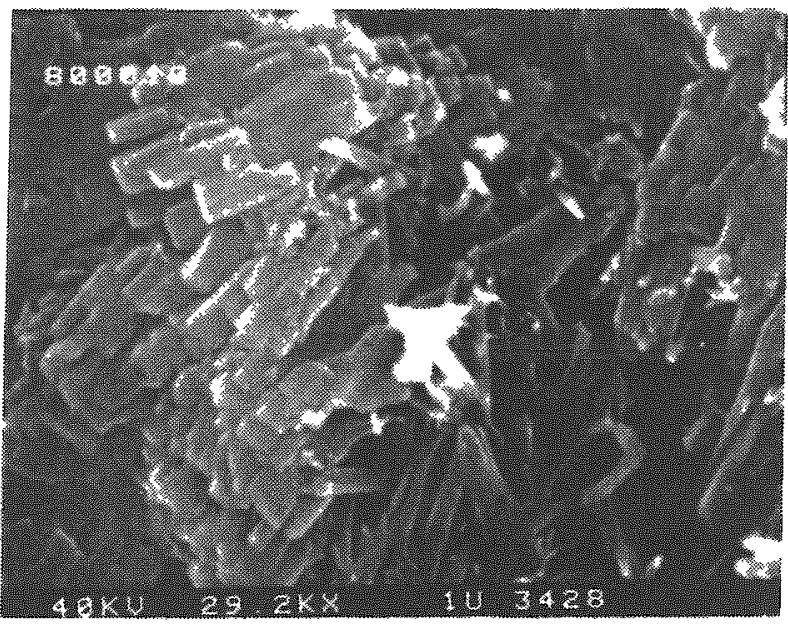

(b)

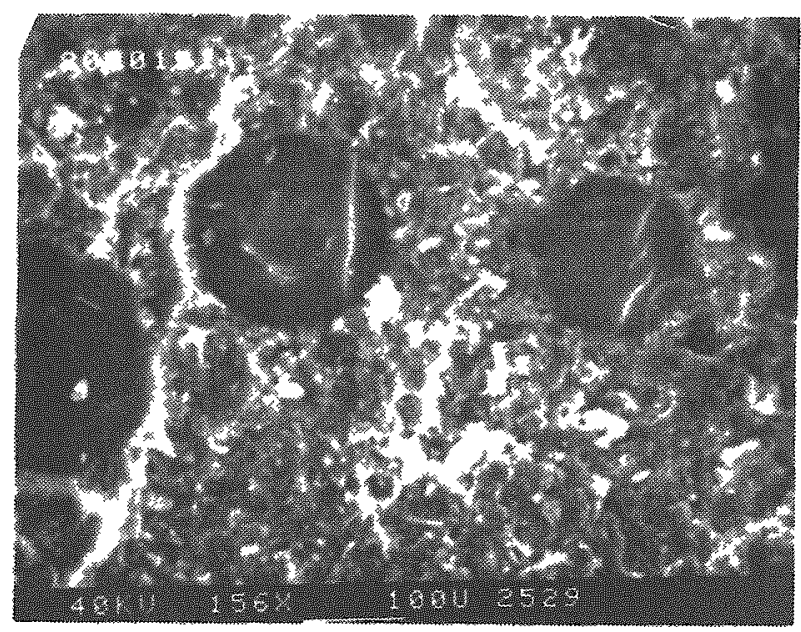

(c)

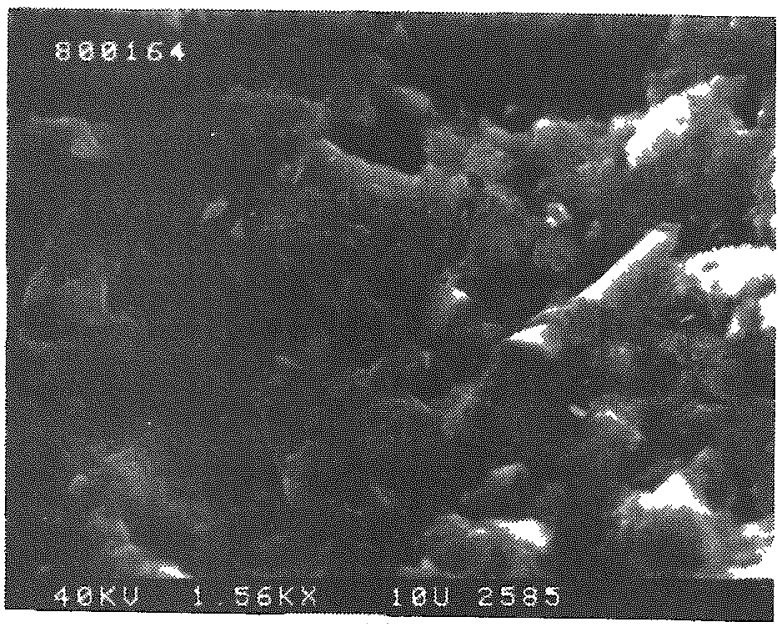

(d)

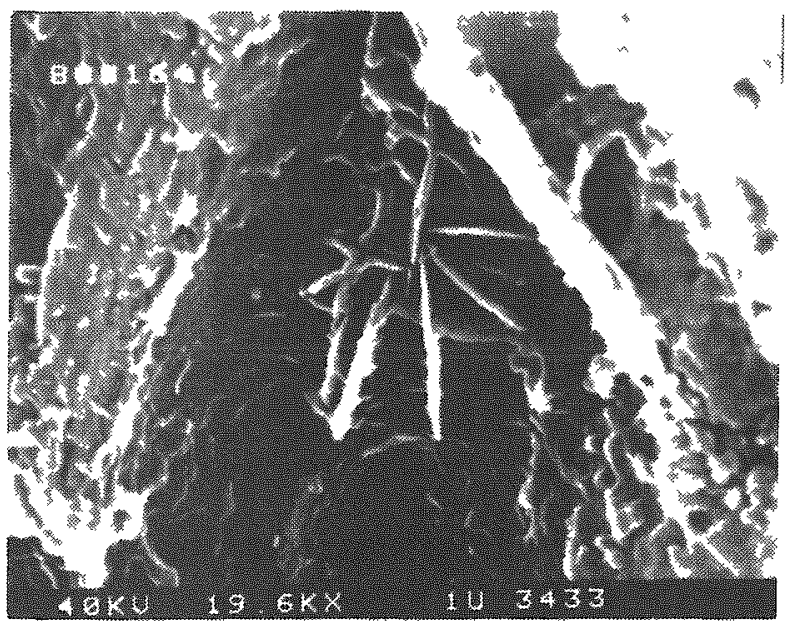

(e)

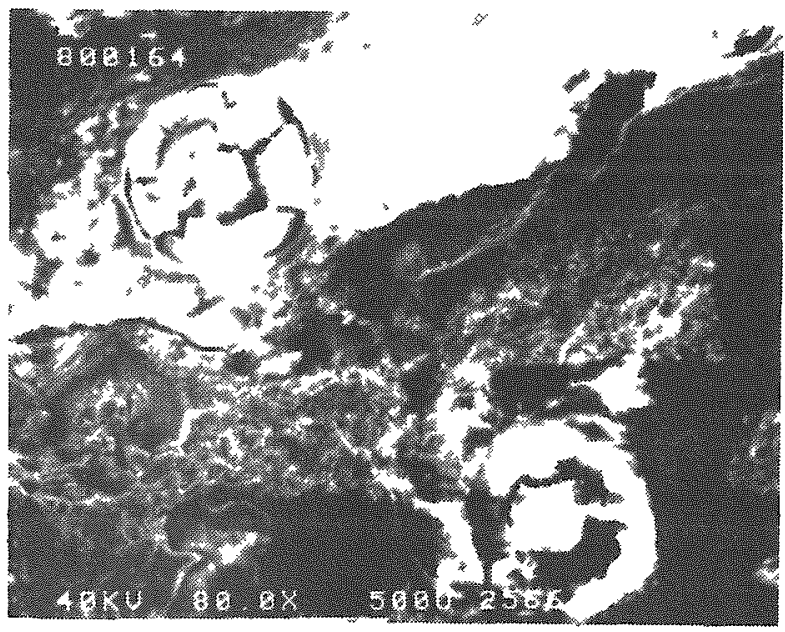

(f) 
Figure 3.3.5. SEM images of 7 -day, $27^{\circ} \mathrm{C}$ cured samples of mixture 79-040.

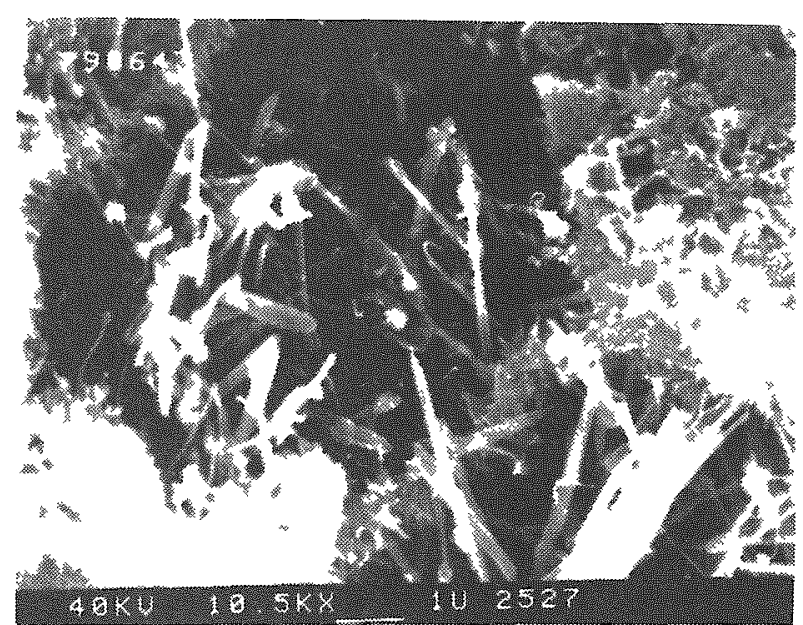

(a)

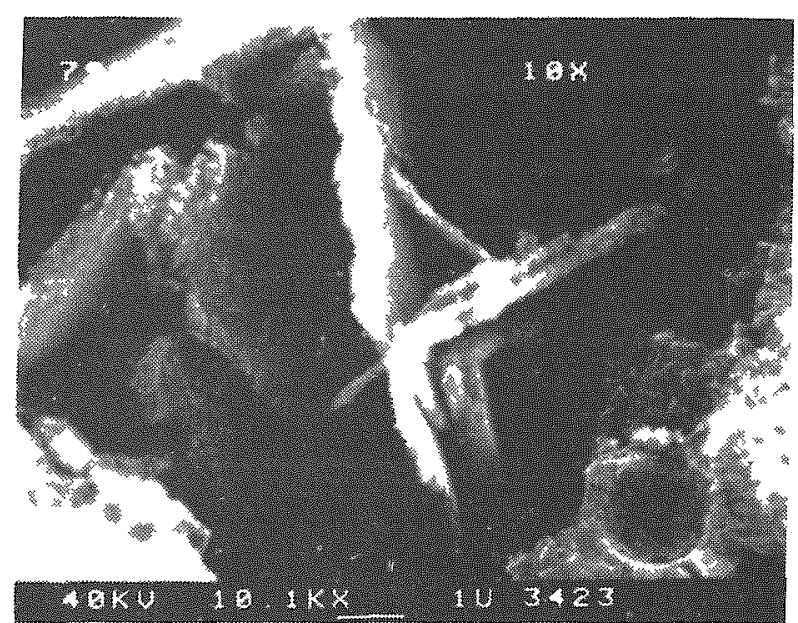

(c)

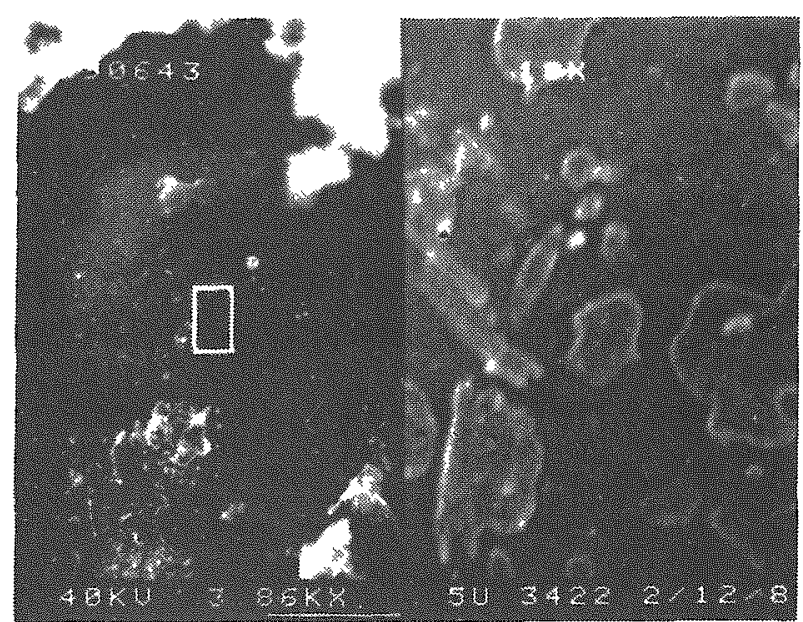

(e)

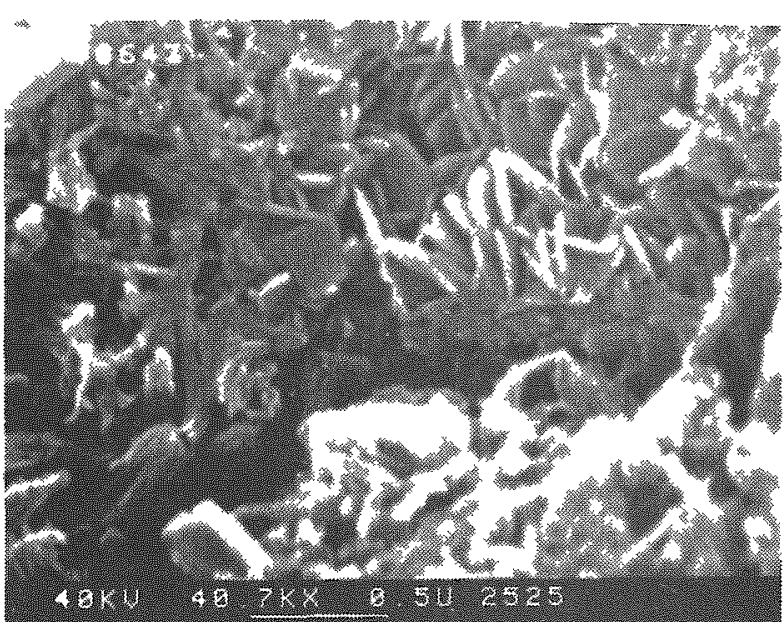

(b)

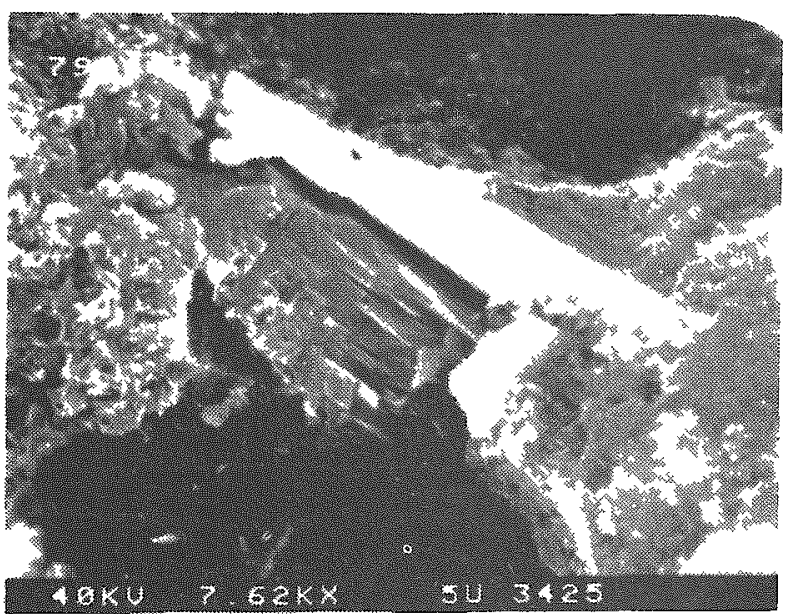

(d)

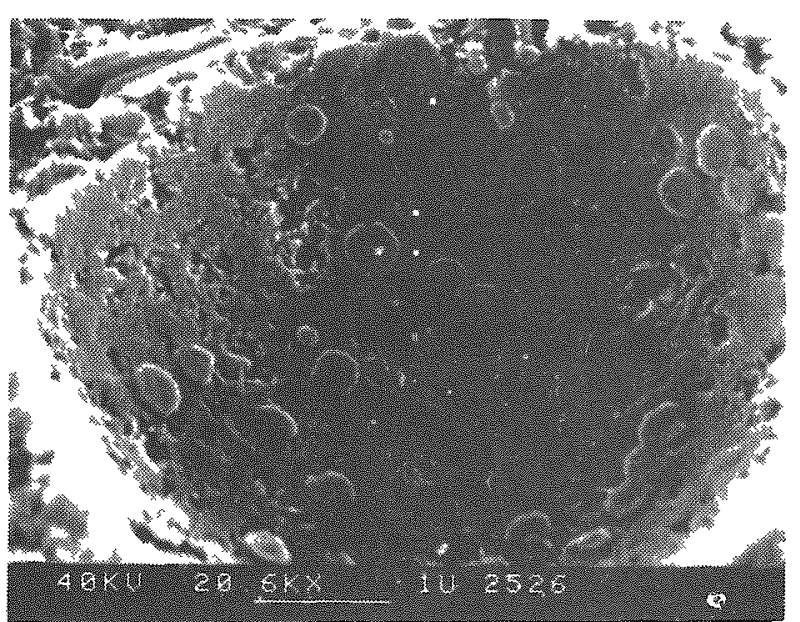

(f) 
and c). View (d) gives details of some massive $\mathrm{Ca}(\mathrm{OH})_{2}$ which is common in the sample. Views (e) and (f) show some details of the reaction of fIy ash. In view (e) the fly ash sphere is somewhat attacked, showing a pocked surface, which seems to have some crystals adhering to it. View (f) shows a typical pull-out feature, a fly ash void produced during sample preparation. The hydrated material in the void gives the impression of blade-like crystals with some occasional rounded crystals on this surface. The former may be AFt or AFm phases produced by the aluminate from the fly ash. The rounded disks are of unknown origin. The presence of many hexagonal plates and ettringite fibers at various early stages is pronounced.

\subsubsection{Summary and Discussion}

The cementitious materials discussed in this section a11 exhibited more than adequate strength development, and permeabilities typically less than $10^{-8}$ darcys. The compressive strengths of the silica-substituted mixtures usually exceeded the values for the sandy mixture (81-010) used as a baseline. Variations in compressive strength from the general pattern of increase with time are not directly correlatable with other measured properties such as permeability. This seems to indicate that such variations in compressive strength are transient features without long-term effects.

The observed reaction of sand grain surfaces at early ages, apparently weakening the cement is a transient one, and all other data indicate that it does not impair overal1 long-term performance. If the cement is partially replaced by a pozzolanic reactive silica source, such as a class F fly ash, slag, or silica fume, modified performance might be expected. In order to explore this concept, additional mixtures were formulated which contained pozzolans as partial replacement for cement and sand. The mixtures discussed in this and previous subsections contained silica fume, slag, class F fly ash, and finely divided quartz.

Although the data are incomplete, they suggest that a viable seal might be formulated from all the materials studied. All appear to have adequate strengths at 28 days. The mechanism of reaction foi the glassy materials may possess similaxities, dependent upon dissolution and precipitation of $\mathrm{C}-\mathrm{S}-\mathrm{H}$. However, the blast furnace slag, though having the larger percent $\mathrm{Ca}$, is much more reactive and apparently more effective in lime removal, whereas the lime-poor fly ash reacted only very slowly (they had approximately the same $\mathrm{SiO}_{2}$ content). 
In addition to the relative reactivity of the two glasses, possibly the $5 \mu \mathrm{m}$ $\mathrm{SiO}_{2}$ Included in the former mixture also entered into the reaction. Additional work is needed on slag and class C fly ash-substituted cements.

Reactions of the above mixtures from $27^{\circ}$ to $60^{\circ} \mathrm{C}$ are of the same general type. Temperature accelerates the reaction, but the phases remain generally the same as at room temperature. At $90^{\circ} \mathrm{C}$, hydration mechanisms and products appear to be somewhat different.

Class $F$ fly ash and quartz react very slowly. They of ten give a low compressive strength value at early stages, but this seems to have little bearing upon the final properties.

The conversion of ettringite to monosulfate with time, characteristic of portland cement hydration, occurs because the materials normally have insufficient sulfate to keep ettringite stable; furthermore, sulfate also enters the C-S-H phase. In most cements, there is not even enough gypsum to maintain monosulfate, and thus the final phase assemblages in mature cementitious materials probably consist of monosulfate and $\mathrm{C}_{4} \mathrm{AH}_{\mathrm{x}}$, along with $\mathrm{C}-\mathrm{S}-\mathrm{H}$ which incorporates sulfate in solid solution.

The series of mixtures discussed in this and the previous sections contained what are commonly accepted as artificial pozzolans and/or quartz as 5 um or $30 \mu \mathrm{m}$ quartz. By definition, pozzolanic materials are those which reduce free $\mathrm{Ca}(\mathrm{OH}){ }_{2}$ through reaction and develop strength by forming $\mathrm{C}-\mathrm{S}-\mathrm{H}$. In this report, we have adopted a broader definition which is free of kinetic limitations, taking the position that given the time of reaction in a repository environment, even sand may be pozzolanic in nature.

If selected 28 -day strengths are plotted against w/c ratio [Figure 3.3 .6 (a)], most mixtures appear to obey the commonly-accepted inverse relationship between compressive strength and w/c ratio. Al1 mixtures except for the cement + sand (81-010), cement + fly ash (79-030), and cement + slag + quartz (79-050) mixtures appear to fall within a narrow shaded area. Apparently, the water content is not totally responsible for the observed variations in compressive strength, implying that in some instances there must be a different mechanism in operation.

In the plot of w/reactive solids vs. 28-day compressive strength [Figure 3.3.6 (b) ], two facts become apparent: 1) all plasticized mixtures are nearly always stronger than non-plasticized mixtures of the same w/s ratio; and 2) the reactivity of the pozzolanic material influences compressive strength (the fumes are more reactive than the fly ashes). Rather than the relationship seen in the 
(a)

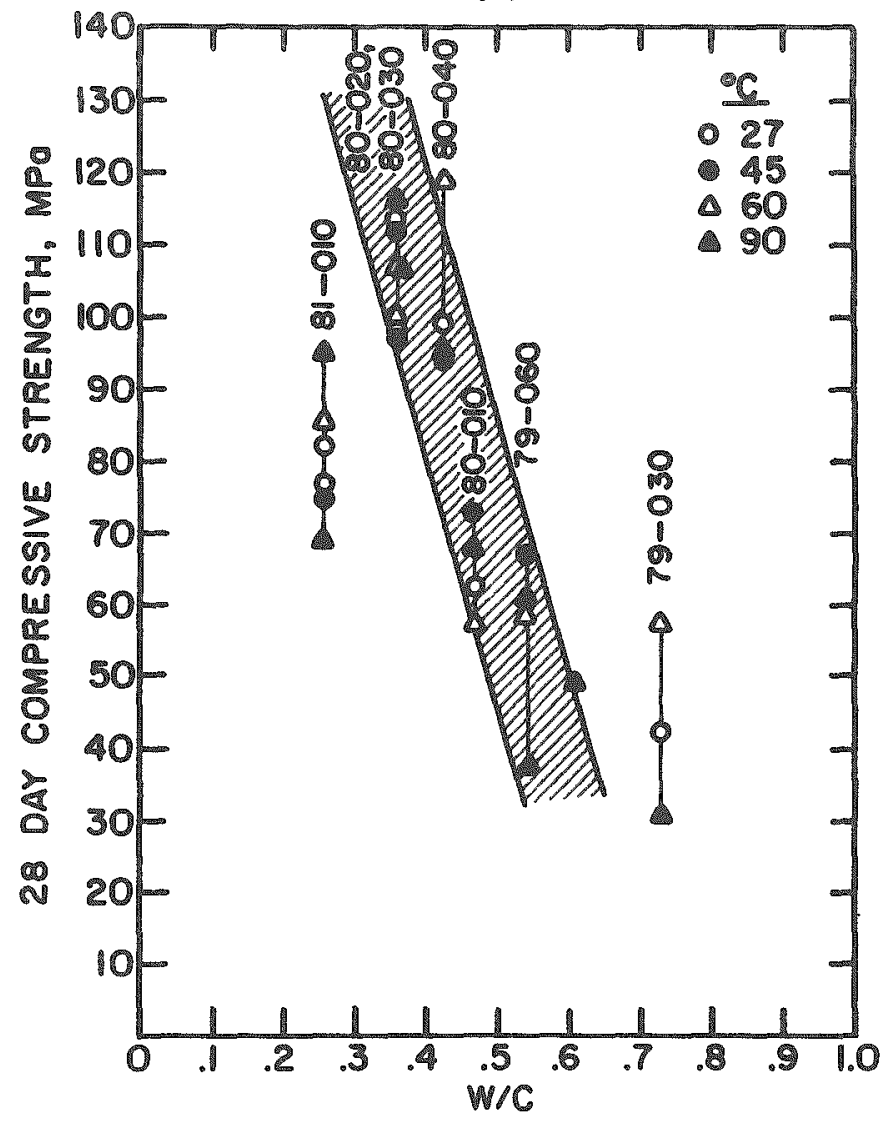

(b)

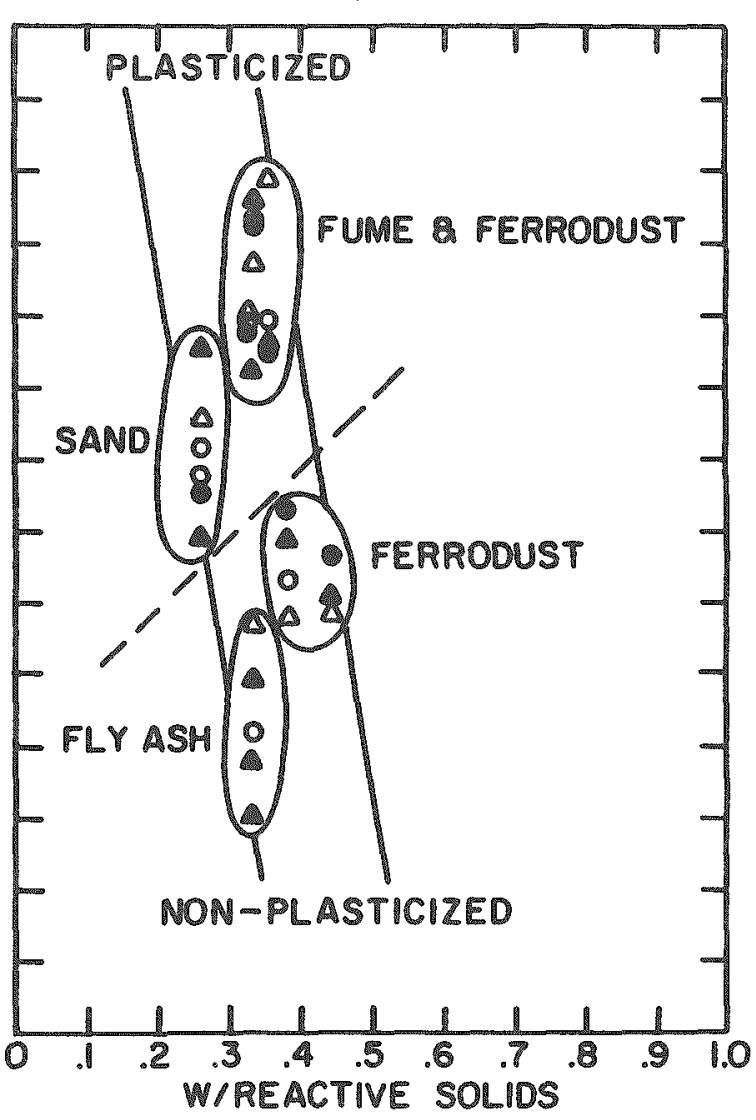

Figure 3.3.6. A comparison of compressive strength vs. water/cement $(\mathrm{w} / \mathrm{c})$ ratio to compressive strength vs. water/reactive solids (w/s) ratio for selected cementitious mixtures. 
w/c plot with exceptions, now the compressive strength behavior can be explained by a single plot with a slightly steeper slope than the plot seen in view (a).

Another generality noted when viewing the data in Figure 3.3 .6 (b) is that mixes containing fume generally had lower permeabilities than their non-fumed counterparts. Densities did not vary in any meaningful way, mainly due to differences in starting materials. Therefore, the lower permeabilities must be related to the reduced water content and resulting higher compressive strengths.

It is concluded that unquestionably better performance can be expected from superplasticized cement formulations. Furthermore, in formulating cementitious mixtures, the w/reactive solid ratio should be taken into account, rather than simply the w/c ratio, which often gives less meaningful results.

\section{$3.4 \mathrm{CaCl}_{2}+\mathrm{NaC1}$ MIXTURES}

\subsubsection{Introduction}

The mixture BCT-1FF appeared to be a feasible grout for use in an anhydriterich environment; salt-saturated portland cement grouts, such as BCT-1F, though less expansive, appeared to be adequate as matrix for cementitious seal materials for some salt-saturated environments; while mixtures such as 80-081 had intermediate properties and higher versatility. Nevertheless, because of some uncertainties regarding stabilities, it is worthwhile investigating other alternative materials designed to be stable in specific environments. The previous expansive mixtures were based upon formation of ettringite as the expansive agent. However, most bedded salt repository horizons, except for anhydrite members, are typified by sulfate activities in the rocks and associated brines which are much lower than those of the chlorides, giving rise to the potential for metastabilities of sulfate-containing phases. Field performance could be a problem if the expansive stress generated by a sulfate-containing phase is degraded with time. In a related study (Ogawa and Roy, 1981) we also established the effects of temperature on limits of expansive phase formation and stability, over a limited pressure range.

The approach in design of typical oil well cements has been to saturate cementitious mixing liquids with sodium chloride to counterbalance the high activities of sodium chloride in such salt-rich horizons. Slight expansive properties are typical of such cementitious materials. Mixtures studied previously in the laboratory, which contained both $\mathrm{NaCl}$ and $\mathrm{CaSO}_{4}$, usually formed 
ettringite, and after extended curing began to develop some calcium monochloroaluminate hydrate, Friedel's salt (Roy et al., 1981, mixture 80-081). The highlime fly ash used in these mixtures was reactive, containing significant amounts of alumina beyond the alumina (and $\mathrm{Fe}_{2} \mathrm{O}_{3}$ ) in the cement phases available for formation of AFt (ettringite) or AFm (Ca monosulfoaluminate and/or Friedel's salt) phases, gehlenite hydrate or other calcium aluminate hydrates (see also Grutzeck et al. (1981b). The initial curing solution used for mixture 80-081 was saturated calcium hydroxide solution (Roy et al., 1981), and because of the apparently high negative free energy of formation of ettringite, the latter phase persisted despite the presence of chloride ions [which were also partly depleted through diffusion into the curing solution (Goto and Roy, 1981)]. After longer periods (56 to 90 days) some Friedel's salt was also apparent in the product of curing in sealed vials. Particularly when exposed to a brine having high NaCl activity, extensive Friedel's salt was present in the product (Wakeley et al., $1981 \mathrm{a}, \mathrm{b})$.

The probable relations of phases may be expressed in a schematic composition diagram of the system $\mathrm{C}_{3} \mathrm{~A}-\mathrm{CaSO}_{4}-\mathrm{CaCl}_{2}$, as presented in Figure 3.4.1. Projections of phases containing water are shown on this base composition triangle. At all times in the cementitious mixtures studied, sufficient water is usually present to form the named hydrates rather than anhydrous phases, at moderate temperatures.

Conventional portland cement pastes normally contain insufficient $\mathrm{SO}_{3}$ for complete reaction of an alunina (and iron oxide)-containing phase to form ettringite or even monosulfoaluminate (shaded area in Figure 3.4.1 labeled conventional cement). As the aluminate phases in cement (including $\mathrm{C}_{4} \mathrm{AF}$ ) react, ettringite is formed at an early stage on surfaces; later, as the sulfate (gypsum) is depleted, reacting with additional aluminate to form monosulfate. Long-term cement hydration products usually contain mixtures of the monosulfate with other calcium aluminate hydrates (some of which are partially carbonated); and alumina and iron oxide are also contained as a solid solution component in $\mathrm{C}-\mathrm{S}-\mathrm{H}$.

The second area of interest is labeled in Figure 3.4 .1 as a sulfate-chloriderich cement. The mixture is typical of what has been described in this report for aluminate-enriched experimental mixtures containing both fly ash (or, to a lesser extent, blast furnace slag) and salt. The obviously preferred chloride "salt" as a component of Friedel's salt is $\mathrm{CaCl}_{2}$, which may be used directly, or it may be obtained indirectly from the reaction of $\mathrm{NaCl}+\mathrm{Ca}(\mathrm{OH})_{2}$, in which case Friedel's salt and $\mathrm{NaOH}$ are reaction products. 


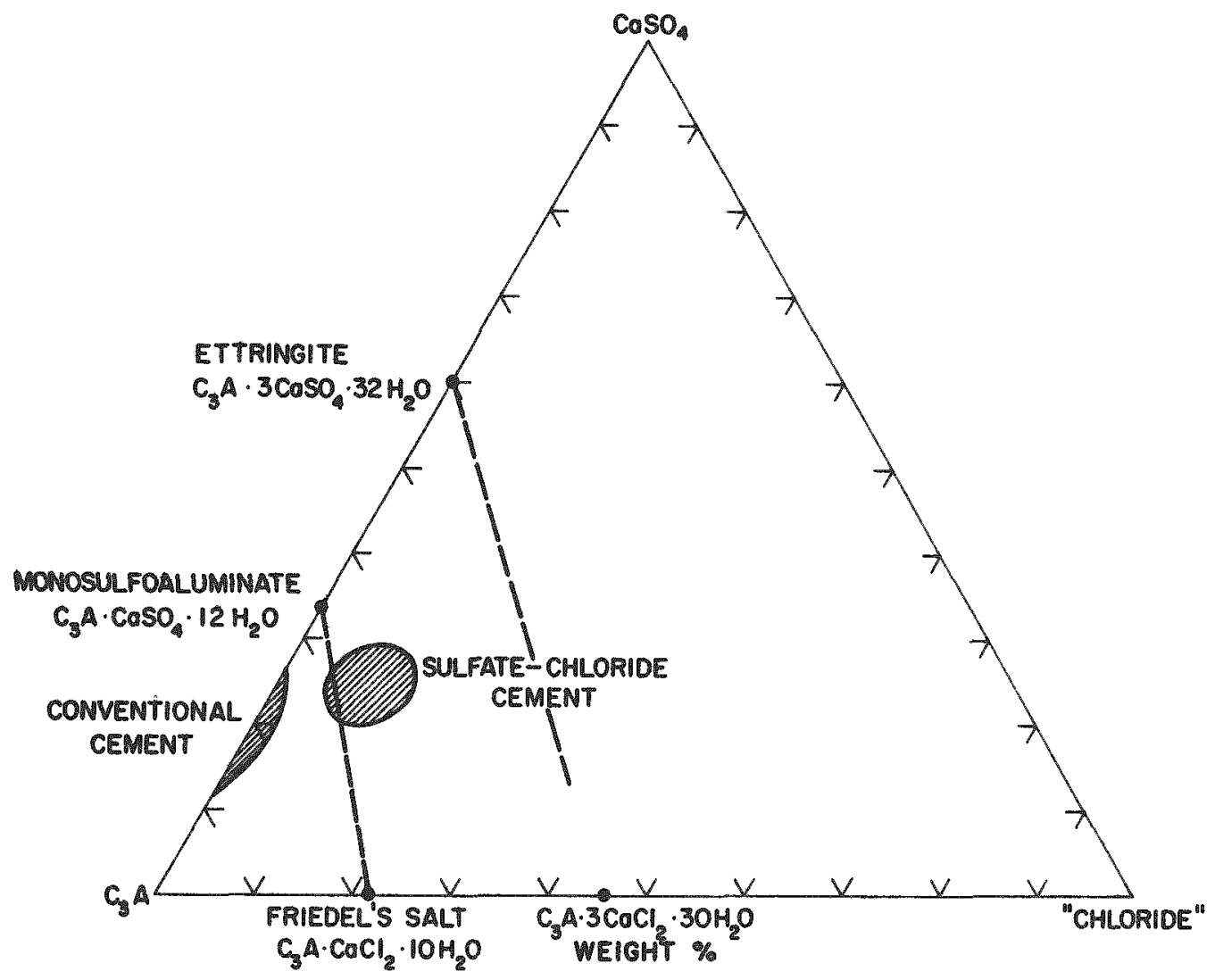

Figure 3.4.1. Schematic composition diagram of potential phase relations in the system $\mathrm{C}_{3} \mathrm{~A}-\mathrm{CaSO}_{4}$ "chloride". 
The mixture 80-081 was such a "sulfate-chloride-rich" cement, as discussed above. The calcium trichloroaluminate hydrate equivalent of ettringite (shown as an "end-member" on the composition triangle, Figure 3.4.1) is not stable at temperatures much above normal room temperature, and was not identified in 80-081 products. In fact, even the ettringite formed in 80-081 after long curing periods in contact with $\mathrm{Ca}(\mathrm{OH})_{2}$ solution was depleted in sulfate, and contained appreciable silica, apparently as partial replacement for sulfate, but very little chloride. In order for phases such as ettringite to form, proper proportions of the constituents must be available: i.e., $\mathrm{CaSO}_{4}, \mathrm{C}_{3} \mathrm{~A}$ (or $\mathrm{Ca}^{++}+$aluminate, ferrite, etc.), and water.

\subsubsection{Rationale for Mixtures}

In order to design seal materials having the greatest potential for stability, or more particularly, for long-term durability, it is necessary both to understand the phase relations, and to determine the effects of any likely phase transformations on physical and mechanical properties. This has been discussed partly in the previous sections. Since slightly expansive materials have been formed from NaCl-saturated mixtures, it is possible that expansion will be generated from $\mathrm{CaCl}_{2}$-containing mixtures as well. Referring to the diagram of Figure $3.4 .1, \mathrm{CaCl}_{2}$ appears to be the preferred constituent to $\mathrm{NaCl}$, from the standpoint of phase stabilities, if the potential for rapid setting can be controlled. Furthermore, it is likely that the high chloride activities present in $\mathrm{CaCl}_{2}$-containing mixtures would be in equilibrium with the $\mathrm{Cl}^{-}$activities in the surrounding rock and brines, enhancing interfacial stability of such a system.

As the Friedel's salt forms slowly from the $\mathrm{CaCl}_{2}$ in solution in the pore fluids, the Ca ions, and the liberated aluminate ions from the fly ash or slag, slight expansion should be generated. The formation of an AFm phase, and absence at elevated temperatures of a stable chloride end member AFt phase (see Figure 3.4.1) would enhance the above product's volume stability, since no AFt (C1ettringite-1ike phase) to AFm transformation would occur. After the mixture is placed, it should expand slightly as available water is used by the calcium aluminate and calcium silicate hydrate processes. Expansion would eventually cease in the dry environment which typically might be found in a salt repository. Should brine begin to intrude into the interfacial region between rock and seal material, it would cause the mixture to swell slightly as additional Friedel's salt was formed via continuing hydration. This expansion would fill any annular 
space; the potential for self-sealing of annular spaces is therefore built into the cement. Even though the expansive forces due to Friedel's salt formation are less than those of ettringite formation, such materials have the potential advantage that in a chloride environment the expansive stress will not be lost. There are, however, some uncertainties about the mechanical properties characteristic of the platy microstructures of Friedel's salt compared with needle-like habit of ettringite, the latter generally considered superior.

In design of all three mixtures described below, nearly the entire aluminate content of the mixtures has been taken into account. The cements have been designed to produce either the room-temperature stable $3 \mathrm{CaCl}_{2}$-AFt (ettringite-1ike) or $1 \mathrm{CaCl}_{2}-\mathrm{AFm}$ (Friedel's salt) phase. In addition to these mixtures, others have been designed which are intermediate to pure $\mathrm{CaSO}_{4}$ and been designed which are intermediate to pure $\mathrm{CaSO}_{4}$ and pure $\mathrm{CaCl}_{2}$ mixtures.

\subsubsection{Formulations}

The compositions of the three mixtures under study are given in Table 3.4.1. The source and/or percent of chloride present differ in the three mixtures. Compositions of the starting materials are given in Appendix A.

The amounts of $\mathrm{CaCl}_{2}$ required to produce either the $\mathrm{AFt}$ or $\mathrm{AFm}$ phases described previously were calculated from the percentage alumina in the mixtures as follows:

\begin{tabular}{|c|c|c|c|}
\hline constituent & wt, $g$ & $\% \mathrm{AI}_{2} \mathrm{O}_{3}$ & total wt $\mathrm{Al}_{2} \mathrm{O}_{3}, \mathrm{~g}$ \\
\hline cement & 60 & $(3.5)$ & 2.1 \\
\hline silica fume & 10 & $(0.05)$ & negligible \\
\hline class $C$ fly ash & 15 & $(17.4)$ & 2.61 \\
\hline class F fly ash & 15 & $(27.0)$ & 4.05 \\
\hline & & & $8.76 \mathrm{~g} \mathrm{tc}$ \\
\hline
\end{tabular}

For the purpose of this calculation the rest of the contents were assumed to be inert fillers. The number of moles of $\mathrm{Al}_{2} \mathrm{O}_{3}$ present per $100 \mathrm{~g}$ of the constituents above is approximately 0.086 ; for complete conversion to ettringite or a $\mathrm{CaCl}_{2}$ equivalent AFt phase, 0.258 moles of either $\mathrm{CaSO}_{4}$ or $\mathrm{CaCl}_{2}$ is required. In this case, $28.6 \mathrm{~g}$ of $\mathrm{CaCl}_{2}$ would be required for the $\mathrm{AFt}$ phase and $9.53 \mathrm{~g}$ for the AFm (Friedel's salt) phase. Because $100 \%$ reaction of $\mathrm{Al}_{2} \mathrm{O}_{3}$ is not expected, the mixtures in Table 3.4 .1 deliberately contain slightly less than the required 
Table 3.4.1. Mixtures for salt repository strata.

\begin{tabular}{|c|c|c|c|c|}
\hline & & \multicolumn{3}{|c|}{ mixture } \\
\hline & code no. & $\begin{array}{c}82-02 \\
3 \mathrm{XaCl}_{2}\end{array}$ & $\begin{array}{c}82-13 \\
1 \mathrm{X} \mathrm{CaCl} \\
2\end{array}$ & $\begin{array}{l}82-14 \\
\mathrm{NaCl}\end{array}$ \\
\hline class $\mathrm{H}$ cement & $\mathrm{H}-9$ & 49.02 & 55.83 & 53.78 \\
\hline Litepoz & B15 & 12.27 & 14.00 & 13.44 \\
\hline Ohio fume & B51 & 8.17 & 9.30 & 8.96 \\
\hline fly ash & B25 & 12.25 & 14.00 & 13.44 \\
\hline C 109 sand & C38 & 89.87 & 102.35 & 98.59 \\
\hline $\mathrm{NaCl}$ & P05 & & & 10.37 \\
\hline $\mathrm{CaCl}_{2}$ (anhydrous) & P07 & 18.30 & 6.95 & \\
\hline citric acid & P27 & 0.20 & 0.93 & \\
\hline superplasticizer & A41 & 0.82 & 0.93 & 0.90 \\
\hline defoamer & $\mathrm{A} 27$ & $0.3 \%$ & & \\
\hline water & E01 & 23.0 & 32.57 & 25.21 \\
\hline$w / c$ & & 0.47 & 0.58 & 0.47 \\
\hline $\mathrm{w} / \mathrm{s}$ & & 0.23 & 0.33 & 0.25 \\
\hline
\end{tabular}

*apops 
amounts of $\mathrm{CaCl}_{2}$ or $\mathrm{CI}$ derived from $\mathrm{NaCl}$ to produce the required phases. The $\mathrm{C}-\mathrm{S}-\mathrm{H}$ should incorporate some of the alumina while additional sulfate and carbonate ions would probably enter into solid solution with the $\mathrm{Cl}$ in the AFt or AFm phases, thereby requiring less chloride.

For the same reason, iron oxide was neglected in the calculation, to keep the mixture slightly deficient in $\mathrm{CaCl}_{2} \cdot \mathrm{xH}_{2} \mathrm{O}$. A strong retarder, citric acid, was used in order to counteract the accelerating effects of large amounts of $\mathrm{CaCl}_{2}$. Interestingly, the $3 \mathrm{X} \mathrm{CaCl}_{2}$ mixture (82-02) needed much less citric acid than the $1 \times \mathrm{CaCl}_{2} \mathrm{mix}(82-13)$ to prevent rapid setting. The $\mathrm{NaCl}$ functioned as a retarder in mixture $82-14$.

Samples of the three mixtures were cast as $50.8-\mathrm{mm}$ cubes and cylinders 25.4 by $50.8-\mathrm{mm}$ 1ong, after mixing according to modified ASTM C 305 procedures (see section 3.5.3). The $\mathrm{CaCl}_{2}$ was first dissolved in the water and allowed to cool to room temperature. The high-range water reducer was added next, followed by the silica fume, the other solid materials, and sand in sequence, with specified mixing between additions. These samples were cured for 1-2 days at temperature in sealed molds. Upon demolding, samples were cured in either WIPP-B brine* or at the vapor pressure of water above the same brine solution.

Additional samples of each mixture were cast in 50.8-mm diameter stainless steel cylindrical molds (rings) to gain information on expansion, and for restrained permeability tests. These samples were also aged in brine or water vapor at the vapor pressure above brine, as before.

\subsubsection{Results}

Compressive Strength and Bulk Density. Compressive strength and bulk density for the three mixtures are given in Tables 3.4 .2 and 3.4.3. The strengths of mixture 82-02 ( $3 \mathrm{X} \mathrm{CaCl}_{2}$ ) are strongly temperature-dependent, being higher at higher temperatures, as are the initial rates of strength development. Mixture 82-13 (1X $\mathrm{CaCl}_{2}$ ) has similar strength development, but the strengths of the $90^{\circ} \mathrm{C}$ samples are slightly lower than their $60^{\circ} \mathrm{C}$ counterparts. The data for mixture 82-14 (containing $\mathrm{NaC1}$ ) also show strength increase with time, but at a much lower rate than either $82-02$ or $82-13$ ( $\mathrm{NaCl}$ is a retarder when used in high concentrations). However, the results are not entirely straightforward, as some samples apparently have a dip in strength development at 14 days. Values at

\footnotetext{
*see Table 2.2 .6 for composition of the brine.
} 
Table 3.4.2. Compressive strength of chloride mixtures (MPa).

\begin{tabular}{ccccc}
\hline \multirow{2}{*}{$\begin{array}{c}\text { specimen } \\
\text { age } \\
\text { (days) }\end{array}$} & $\begin{array}{l}\text { cure } \\
\text { temp. } \\
\left({ }^{\circ} \mathrm{C}\right)\end{array}$ & $82-02$ & $82-13$ & $82-14$ \\
\cline { 3 - 5 } & & & \multicolumn{3}{c}{ mixture } \\
\hline 3 & 38 & 11.8 & 17.4 & 28.7 \\
& 60 & 21.6 & 52.5 & 60.7 \\
& 90 & 43.6 & 35.9 & 31.8 \\
7 & 38 & 19.0 & 33.7 & 35.4 \\
& 60 & 32.5 & 72.7 & 51.7 \\
& 90 & 64.4 & 64.6 & 34.9 \\
& 38 & 17.3 & 34.7 & 30.6 \\
& 60 & 32.9 & 45.2 & 43.2 \\
& 90 & 26.9 & 71.8 & 36.8 \\
& 38 & 38.8 & 50.8 & 46.9 \\
& 60 & 40.0 & 47.5 & 60.0 \\
& 90 & 53.5 & 47.1 & 45.1 \\
& 90 & & & \\
\hline
\end{tabular}

Table 3.4.3. Bulk density of chloride mixtures $\left(\mathrm{g} / \mathrm{cm}^{3}\right)$.

\begin{tabular}{|c|c|c|c|c|}
\hline \multirow{2}{*}{$\begin{array}{l}\text { specimen } \\
\text { age } \\
\text { (days) }\end{array}$} & \multirow{2}{*}{$\begin{array}{l}\text { cure } \\
\text { temp. } \\
\left({ }^{\circ} \mathrm{C}\right)\end{array}$} & \multicolumn{3}{|c|}{ mixture } \\
\hline & & $82-02$ & $82-13$ & $82-14$ \\
\hline 3 & $\begin{array}{l}38 \\
60 \\
90\end{array}$ & $\begin{array}{l}1.81 \\
1.89 \\
1.95\end{array}$ & $\begin{array}{l}1.90 \\
1.85 \\
1.82\end{array}$ & $\begin{array}{r}-- \\
-- \\
1.77\end{array}$ \\
\hline 7 & $\begin{array}{l}38 \\
60 \\
90\end{array}$ & $\begin{array}{l}1.85 \\
1.95 \\
1.98\end{array}$ & $\begin{array}{l}1.77 \\
1.74 \\
1.82\end{array}$ & $\begin{array}{l}2.02 \\
2.06 \\
1.75\end{array}$ \\
\hline 14 & $\begin{array}{l}38 \\
60 \\
90\end{array}$ & $\begin{array}{l}1.91 \\
1.96 \\
2.00\end{array}$ & $\begin{array}{l}1.79 \\
1.78 \\
1.81\end{array}$ & $\begin{array}{l}1.72 \\
2.05 \\
1.74\end{array}$ \\
\hline 28 & $\begin{array}{l}38 \\
60 \\
90\end{array}$ & $\begin{array}{l}1.92 \\
1.92 \\
2.00\end{array}$ & $\begin{array}{l}1.82 \\
1.83 \\
1.84\end{array}$ & $\begin{array}{l}1.96 \\
1.96 \\
1.72\end{array}$ \\
\hline
\end{tabular}


28 days seem to cluster between 38 and $60 \mathrm{MPa}$, which seems to suggest a relative lack of sensitivity of the mixtures to the source and of chloride present.

Permeability. Two preliminary studies of permeability of the 82-02 mixture were carried out after about one week of curing. One sample consisted of a solid 50.8-mm specimen cast in a stainless steel ring and subsequently cured in saturated WIPP-B brine. The second sample consisted of the $3 \mathrm{X} \mathrm{CaCl}_{2}$ mixture mixed with half as much halite aggregate of $4.75 \times 2-m m$ size. This sample was cured in air with $>95 \% \mathrm{rh}$. After one week the solid disk was laced with surface cracks. However, this sample's permeability to brine was quite low. No liquid had permeated the sample. After approximately two days at 100-300 psi brine pressure, the pressure was increased to 400 psi. Once established, the flow rate was very low. In contrast, the salt aggregate sample showed immediate flow to brine once pressure was applied, possibly due to the solubility of the aggregate at elevated pressure. The fact that the flow rate decreased with time was encouraging. At the termination of the experiment the flow was $\sim 6 \times 10^{-2}$ darcys and falling. This was the first salt aggregate sample to give a flow rate slow enough to be measurable (others failed immediately under pressure). Additional data for all three mixtures are given in Table 3.4.4. The impermeability of mixture 82-02 was reconfirmed. The salt mixture (82-14) also had a low permeability. The $1 \mathrm{X} \mathrm{CaCl}{ }_{2}$ mixture designed to produce Friedel's salt, on the other hand, showed rapid flow.

Microstructures: SEM. SEM images of the $3 \mathrm{X} \mathrm{CaCl}_{2}$ paste hydrated in E17 brine for 5 to 7 days at $38^{\circ} \mathrm{C}$ are given in Figure 3.1 .2 . The mix was expansive (could see macro effects in the sample), and the abundance of Friedel's salt ( $x$-ray diffraction confirmed) lends support to this expansive character, which is strongly suggested by the crystal development shown in Figure 3.4.2. View (a) is comprised of the single needle, blade- or plate-shaped area found in the sample. However, rather than approximate an ettringite composition, these crystals are rich in $\mathrm{Ti}, \mathrm{S}$, and $\mathrm{Ca}$, with minor amounts of $\mathrm{Si}$ and $\mathrm{C}$. The hexagonal plates shown in views (b) and (c) are more typical of the developing AFm phases. In view (b) one see the development of Friedel's salt having a massive irregular platy nature, with patches of $\mathrm{C}-\mathrm{S}-\mathrm{H}$ honey-comb between the plates. A fly ash void can be seen in the upper left hand (ULH) corner of the photograph. The AFm chemistry is predominantly $\mathrm{Ca}, \mathrm{Cl}, \mathrm{Al}, \mathrm{Fe}$, and Si. The Friedel's salt pictured in view (c) has the more classic development of hexagonal plates. Here crystal 
Table 3.4.4. Permeability data for salt strata mixtures cured at $60^{\circ} \mathrm{C}$ in WIPP-B* brine $\left(\right.$ darcy $\left.\cong \mu \mathrm{m}^{2}\right)$.

\begin{tabular}{|c|c|c|c|}
\hline \multirow{2}{*}{$\begin{array}{c}\text { cure } \\
\text { time } \\
\text { (days) }\end{array}$} & \multicolumn{3}{|c|}{ formulation } \\
\hline & $82-02$ & $82-13$ & $82-14$ \\
\hline 29 & -- & $\begin{array}{l}\text { rapid } \\
\text { flow }\end{array}$ & $2.10^{-7}$ \\
\hline 41 & $<10^{-8}$ & -- & -- \\
\hline 45 & -- & - & $\sim 10^{-7}$ \\
\hline 48 & $<10^{-n} 8$ & - & - \\
\hline
\end{tabular}

*See Table 2.2.6 for composition. 
Figure 3.4.2. SEM images for $38^{\circ} \mathrm{C}$ brine-cured samples of mixture $82-02$.

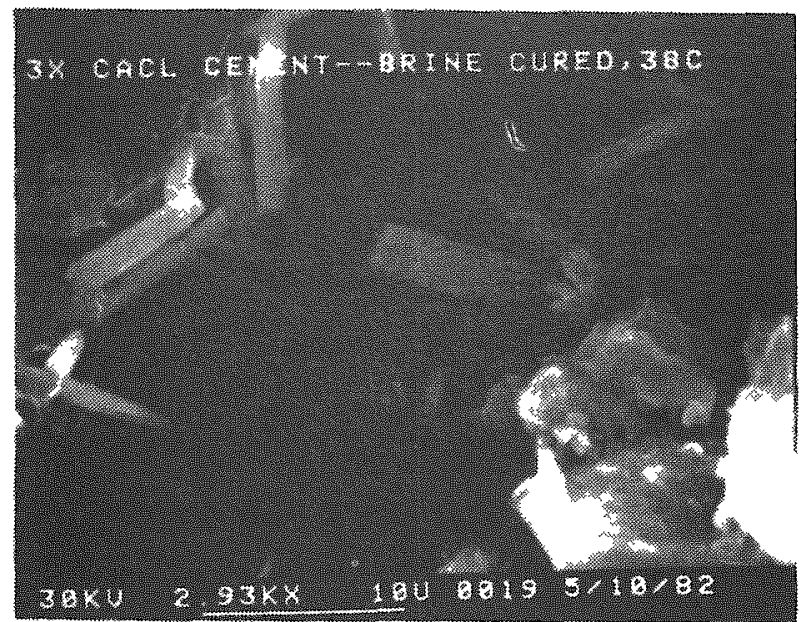

(a)

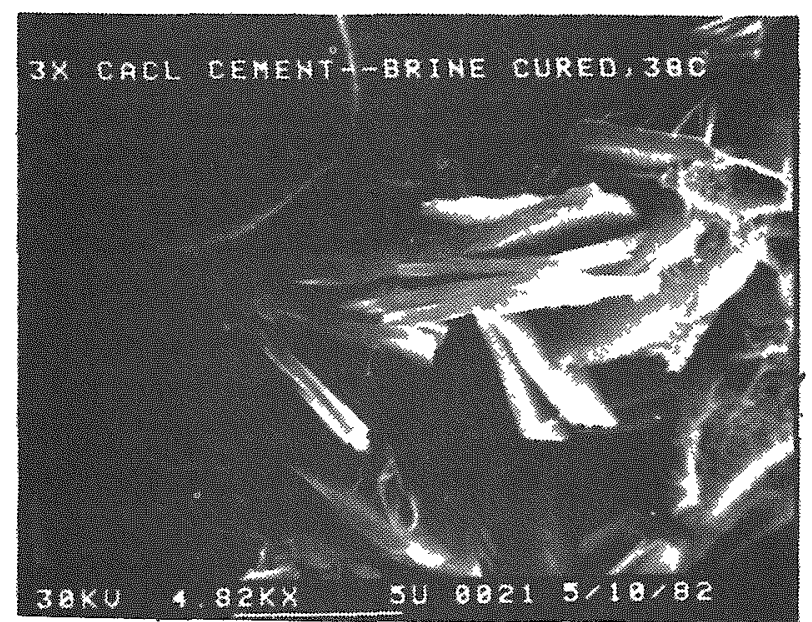

(b)

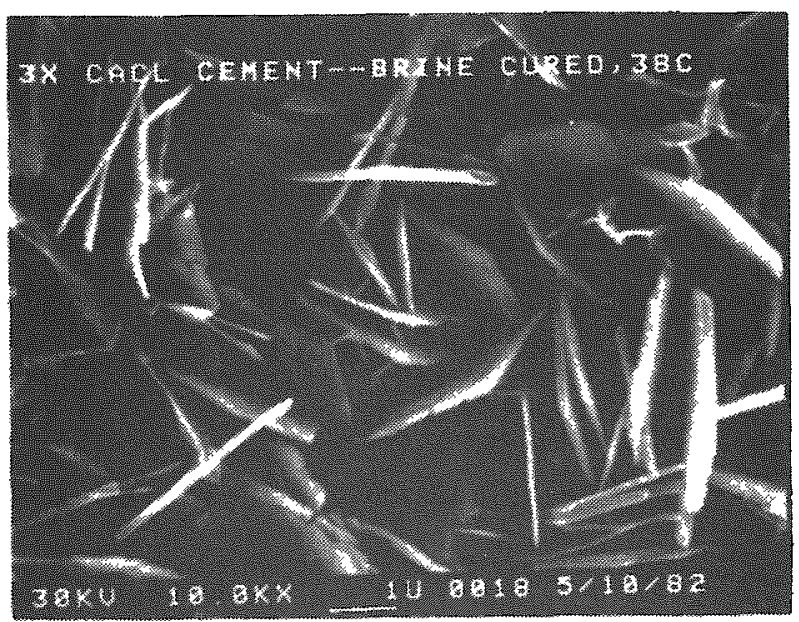

(c) 
growth probably occurred in an open space or pocket. Its chemistry is also Ca, $\mathrm{C} 1, \mathrm{Si}, \mathrm{Al}$ and $\mathrm{Fe}$. Again, $\mathrm{C}-\mathrm{S}-\mathrm{H}$ can be seen binding some of the plates together. In Figure 3.4 .3 are presented additional data for the $3 \mathrm{X} \mathrm{CaCl}_{2}$ mixture, but for samples cured for five days at room temperature at the rh above saturated E17 brine (views $\mathrm{a}-\mathrm{c}$ ), and at $38^{\circ} \mathrm{C}$ in saturated $\mathrm{NaCl}$ brine (views $\mathrm{d}-\mathrm{f}$ ), respectively. In each case the morphology of the AFm crystals is nearly the same. The hexagonal plate development in (views a-c) is ubiquitous, but this sample was taken from near the surface. Most everything in the pocket shown in view (a) is covered by some crystals. The round fly ash spheres are evidently covered by these crystals and in some instances are being held together by them. Close-ups of various areas are shown in views (b) and (c). $\mathrm{C}-\mathrm{S}-\mathrm{H}$ is again evident between the hexagonal plates, holding then together. In all cases, the chemistry of the plates is as follows: $\mathrm{Ca}, \mathrm{Cl}$, Si, Al, Fe, with occasional traces of $\mathrm{K}$ and $\mathrm{Ti}$. The development of the hexagonal Friedel's salt in views $d-f$ is less striking. This may be due in part to the area of the sample investigated. The previous sample was taken from near the surface, while this one, which was cured in NaCl brine, was taken from deeper in the sample. All three views show hexagonal plates develoment ranging from the very crystalline rosettes in view (d) to the more massive matrix material view (e), and containing $\mathrm{C}-\mathrm{S}-\mathrm{H}$ (view $\mathrm{f}$ ). The chemistry of the view (e) crystals, presumably laths and plates on edge, is $\mathrm{Ca}, \mathrm{Cl}$, and $\mathrm{Si}$. This may be an AFm phase. The chemistry of the plates in view (f) consists of $\mathrm{Ca}, \mathrm{Cl}$ and $\mathrm{Al}$, as expected for Friedel's salt formation.

Phases Present: X-ray Diffraction. X-ray results show the presence of significant Friedel's salt (PDF \#19-201) at all times in the $\mathrm{CaCl}_{2}$ mixtures. The reduced relative intensity of peaks for Friedel's salt in samples of the NaCl salt mixture indicate that the amount is greatly reduced relative to $\mathrm{CaCl}_{2}$ mixes. Its presence is questionable in all samples of mix $82-14$ cured at $90^{\circ} \mathrm{C}$. Gypsum (PDF \#21-816) appears in 3-day samples of 82-02, disappearing at longer times; and in $38^{\circ}$ samples of $82-14$, diminishing with both higher curing temperatures and longer

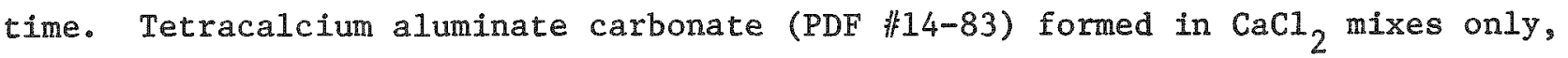
increasing with both higher temperature and longer time as calcium chloride 6hydrate (PDF \#26-1053) decreases. Ettringite remains until 28 days at $38^{\circ}$ in $82-$ 02 and 82-13 samples, but is not detectable at increased time or temperature, nor in $\mathrm{NaCl}$ samples. $\mathrm{Ca}(\mathrm{OH})_{2}$ is minor but detectable in samples of 82-02 and 82-14 only at $38^{\circ}$ up to 14 days hydration. $C_{2}$ SH (PDF 
Figure 3.4.3. SEM images of mixture 82-02 cured in various environments at room temperature and $38^{\circ} \mathrm{C}$.

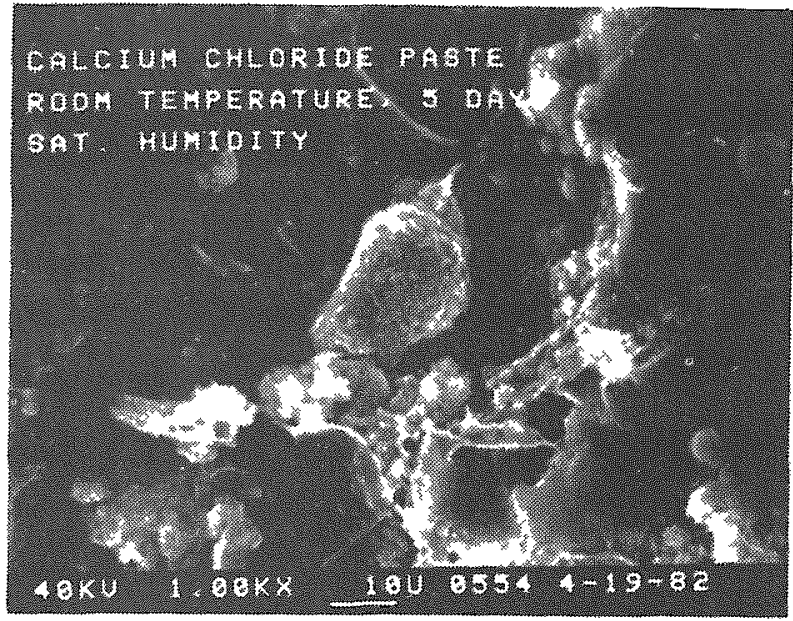

(a)

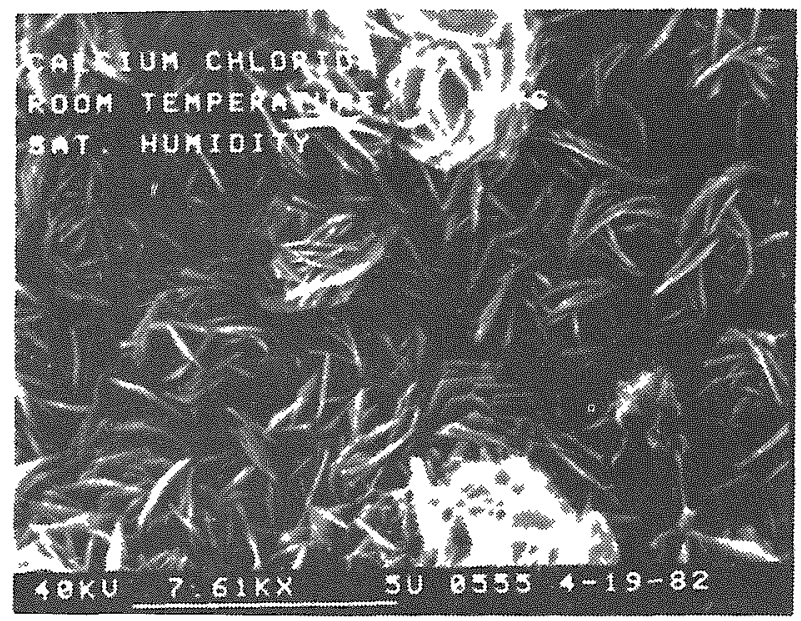

(b)

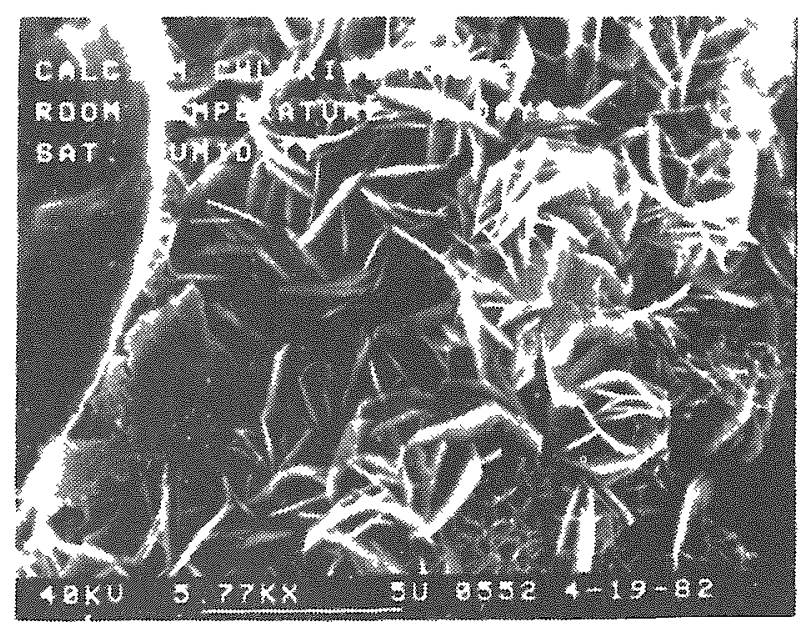

(c)

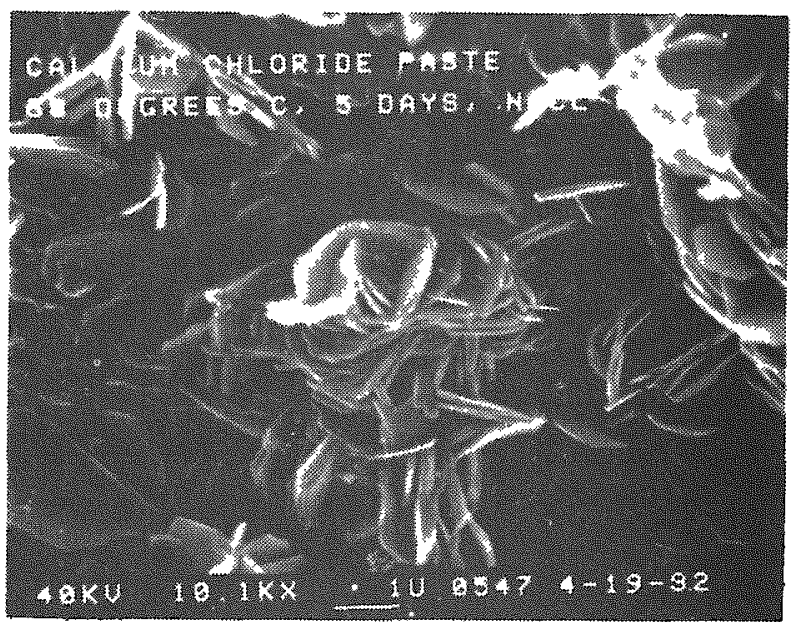

(d)

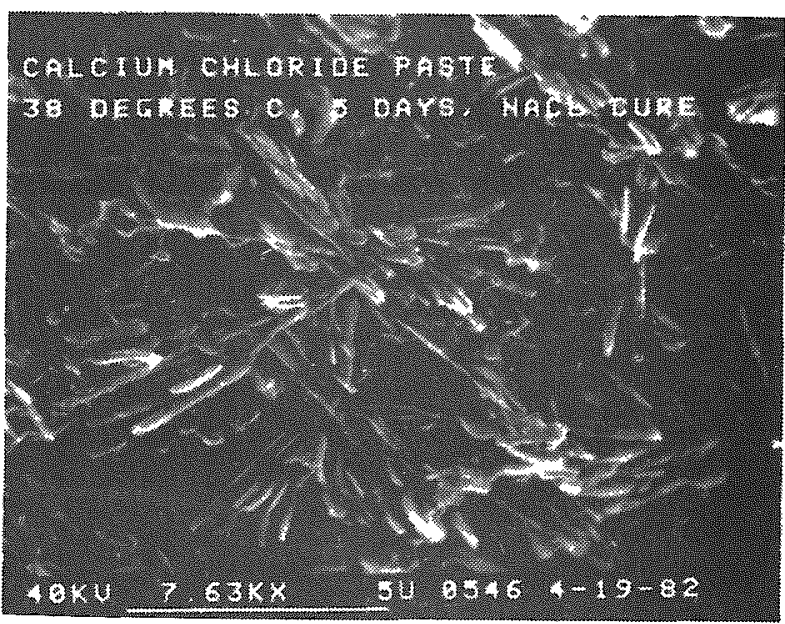

(e)

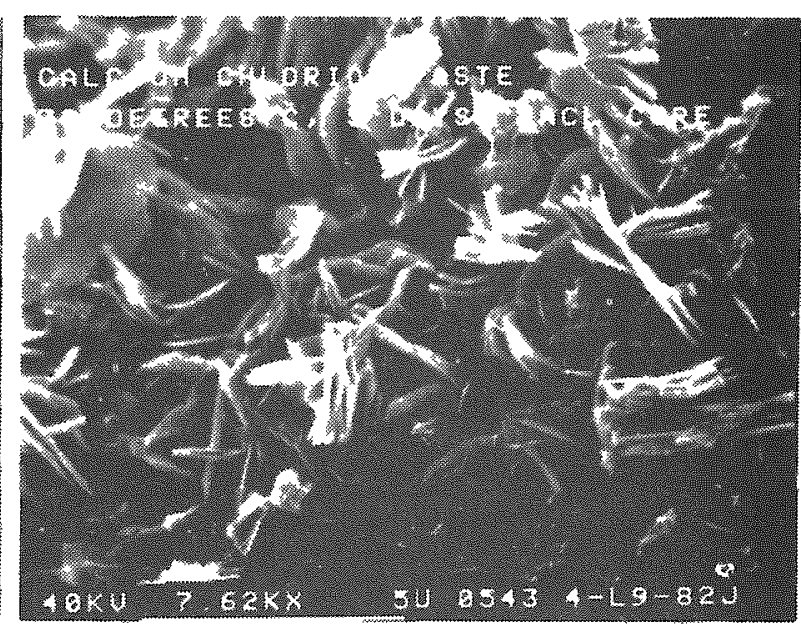

(E) 
low strength to cured pastes with a high Ca:Si ratio, appears to be a constituent of al1 samples, especially those from higher temperatures, but its identification is tentative. See Table 3.4 .5 for a summary of phases detected by $x$-ray diffraction.

Restrained Samp1es. Mixtures 82-02, 82-13, and 82-14 cast in 50.8-mm ID stainless steel cylindrical molds (rings) were allowed to cure one day at temperature, after which they were immersed in simulated WIPP-B brine (E17) or placed in the air environment at the relative humidity over the brine to continue curing.

Table 3.4.6 presents observations of both the restrained rings and equivalent brine-cured bars for mechanical properties tests. Of the three mixtures cured in the aix environment, only the $1 \times \mathrm{CaCl}_{2}$ mixture (82-13) exhibited shrinkage (the $38^{\circ}$ and $60^{\circ} \mathrm{C}$ samples were loose in their rings). A11 brinecured samples, with the exception of the 41-day cured 82-13 samples, were still tightly held in their respective rings. Of the unrestrained bars, only the bar of 82-02 cured in brine at $38^{\circ} \mathrm{C}$ showed visible cracking at the time of observation. These data demonstrate that an expansive formulation will seal, and that the degree of sealing is a function of the degree of expansion. Apparenty the 82-13 samples shrink somewhat with time or do not expand very much even when immersed in brine.

Dynamic Young's Modulus. Data for the dynamic Young's modulus of mixtures 82-02, 82-13 and 82-14 are prsented in Table 3.4.7. The values generally increase in magnitude with both time and temperature. The single exception is the temperature dependence of mixture $82-13$ at $90^{\circ} \mathrm{C}$. Its values increase with time, but are lower than the $60^{\circ} \mathrm{C}$ counterpart. This behavior was not observed at such low temperatures but occurred in other materials at $250^{\circ} \mathrm{C}$.

\section{4 .5 Discussion}

An expansive cement should be an asset in plugging salt strata since the host rock salt is deformable. For this reason a series of conventional potentially expansive cementitious materials (containing $7-18 \% \mathrm{CaCl}_{2}$ ) were formulated and tested, in parallel with a high-NaCl content mixture.

The high chloride ion activity of such cements should also inhibit the dissolution of NaCl from the host rock. Mixtures containing sufficient $\mathrm{CaCl}_{2}$ to react with nearly all of the aluminate to form either AFt or AFm phases have 
Table 3.4.5. X-ray difraction phase data for salt strata wixtures.

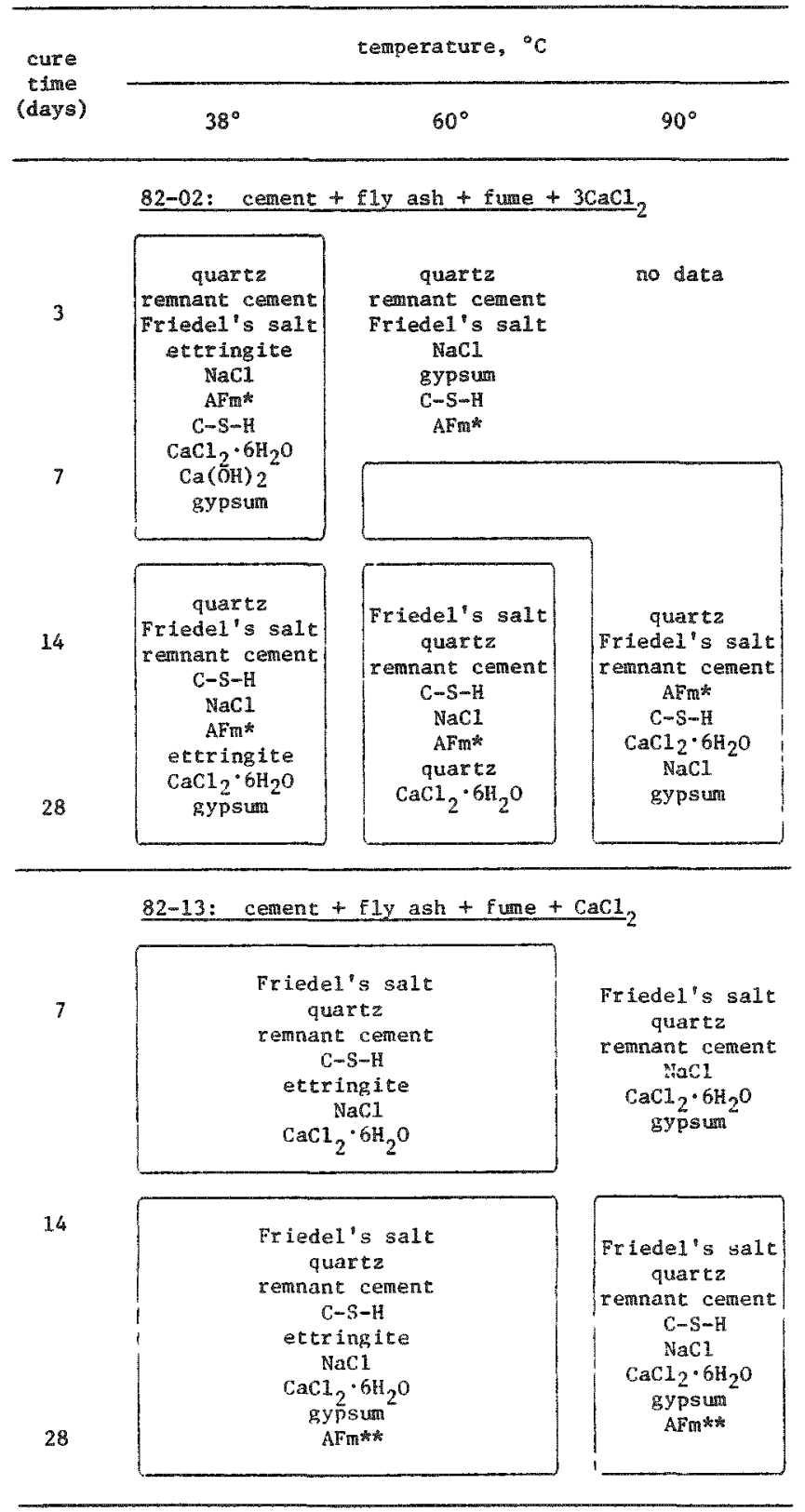

82-14: cement + fly ash + fume + NaC1

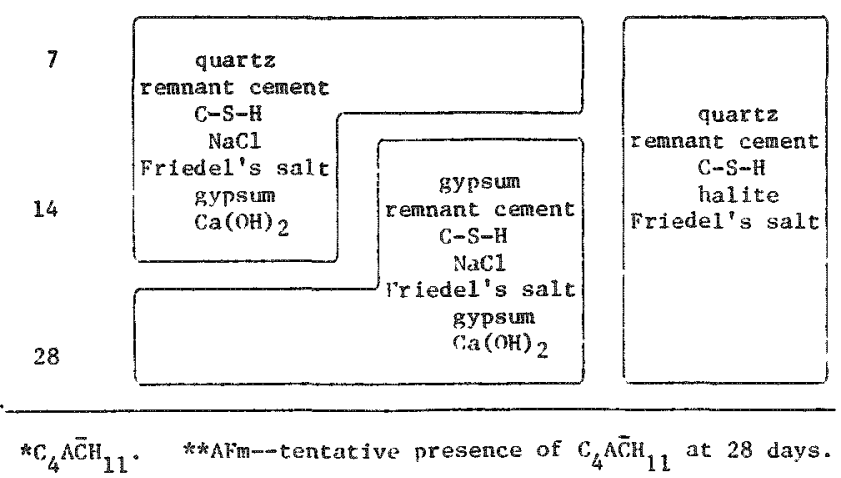


Table 3.4.6. Restrained and unrestrained curing of salt strata mixtures.

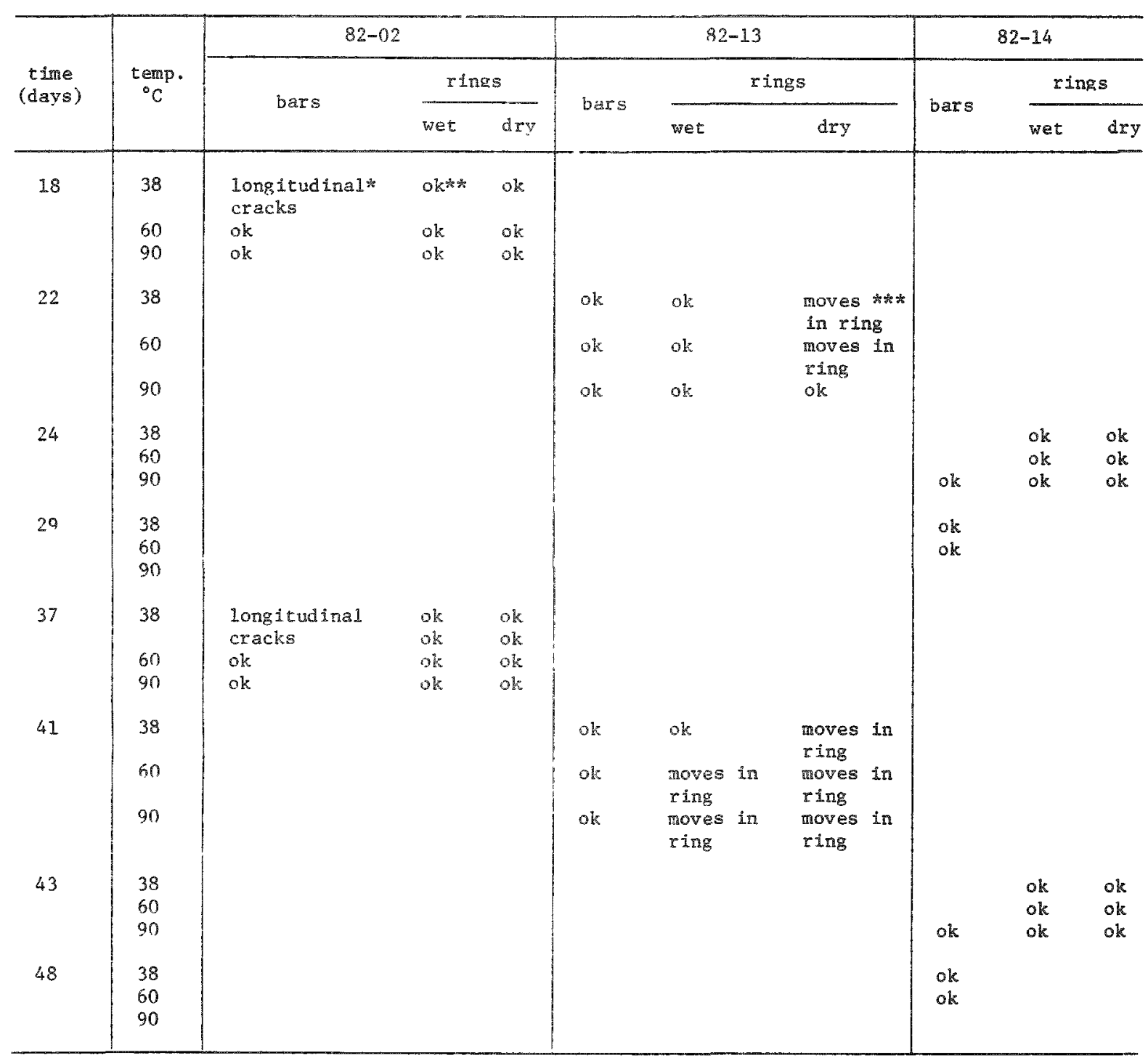

*Cracking due to expansion.

* Signifies that sample is tight in ring-apparenty due to expansion. **t:Sample has shrunk. 
Table 3.4.7. Dynamic Young's modulus $\left(10^{6} \text { psi }\right)^{*}$ of $\mathrm{NaCl}$ and $\mathrm{CaCl}_{2}$ mixtures.

\begin{tabular}{|c|c|c|c|c|c|c|c|c|c|c|c|}
\hline \multirow{2}{*}{ mixture } & \multirow{2}{*}{$\begin{array}{l}\text { curing } \\
\text { temp. } \\
\left({ }^{\circ} \mathrm{C}\right)\end{array}$} & \multicolumn{10}{|c|}{ curing, days } \\
\hline & & 1 & 5 & 8 & 15 & 17 & 21 & 23 & 28 & 32 & 43 \\
\hline $82-02$ & $\begin{array}{l}38 \\
60 \\
90\end{array}$ & long: & dinal & cracks, & no reasc & $\begin{array}{l}\text { ble m } \\
3.77 \\
3.98\end{array}$ & nreme & & $\begin{array}{l}3.84 \\
3.99\end{array}$ & & \\
\hline $82-13$ & $\begin{array}{l}38 \\
60 \\
90\end{array}$ & & & & & & $\begin{array}{l}3.65 \\
4.27 \\
4.12\end{array}$ & & & $\begin{array}{l}3.82 \\
4.26 \\
4.21\end{array}$ & \\
\hline $82-14$ & $\begin{array}{l}38 \\
60 \\
90\end{array}$ & $\begin{array}{l}3.36 \\
4.17\end{array}$ & $\begin{array}{l}3.93 \\
4.51\end{array}$ & $\begin{array}{l}4.02 \\
4.60\end{array}$ & $\begin{array}{l}4.28 \\
4.73\end{array}$ & & & 3.31 & $\begin{array}{l}4.40 \\
4.82\end{array}$ & & 3.33 \\
\hline
\end{tabular}


produced materials with reasonable properties. The addition of 1arge quantities of $\mathrm{CaCl}_{2}$ has not significantly compromised the mixtures' properties; permeability is low in the basic materials. An expansive mixture designed to produce Friedel's salt (chloroaluminate) as the expansive agent seems to hold considerable promise, and in ways may be superior to the expanding cementitious mixtures discussed in part one of the report. Longer term studies with additional mixtures containing varying amounts of $\mathrm{CaCl}_{2}, \mathrm{NaCl}$ and $\mathrm{CaSO}_{4}$ should provide a more full evaluation, establishing phase relationships between the AFt and AFm phases, and determining the effects of activities of component ions from the host environments. This understanding will help to better predict and control the long-term behavior of such expansive cements.

\subsection{CEMENT-BASED COMPOSITES/CONCRETE CONTAINING AGGREGATE FROM EVAPORITE STRATA}

\subsubsection{Selection of Aggregates}

Coarse aggregates representing five different lithologies were chosen for their specific properties to simulate mined-out rock in cementitious composites/ concretes. Mineralogy and physical and mechanical tests of these rocks were summarized in section 2.0. Preliminary experiments included all five types of coarse aggregate.

Properties of early samples showed that the composites with mudstone and sandstone from the Los Medanos site were the least promising, although the cement-based grout did form a bond to these aggregates. After confined curing, which avoided cracking via expansion of clays, the mudstone composites had low permeability to brine. We were unable to test the compressive strength of composites of mudstone from confined curing, however. The very low strength and high permeability of the Santa Rosa sandstone made it unsuitable for aggregate in concrete to be used as structural backfill.

Our experiments showed that it was possible to bond tailored cements to these rocks, so that any penetrations through such soft clastic units can be filled and sealed to the equivalent of the host formation. But additional experiments concentrated on bedded salt and anhydrite, more representative rock types; and on dolostone aggregate, composites of which, not surprisingly, exhibited the highest strength (Wakeley and Roy, 1982a). Data from tests of the low-strength composites were reported previously (Wakeley et al., 1981a). 


\subsubsection{Concrete Mixture Formulations}

of the many mixtures we have tested for use in evaporite strata, two mortars and two grouts were chosen as matrix for composites. Each cementitious formula contained either $\mathrm{NaCl}$ ( 3 of the 4 ) or $\mathrm{CaCl}_{2}$, added to the mixing water. One of the grouts in fact was mixed with E17 brine (simulated WIPP-B). Components of each mix are 1isted in Table 3.5.1. The NaC1 grout was introduced in section 3.1. $\mathrm{NaCl}$ and $\mathrm{CaCl}_{2}$ mortars are described more fully in section 3.4. As mentioned previously, most of the experimental composites were made with one of three coarse aggregates: dolostone, mixed with both mortars and both grouts; crushed bedded salt, with the salt-containing mortar and brine-mixed grout; and anhydrite, with grout. Table 3.5 .2 summarizes these combinations.

The design and testing of mixes $B, C$, and $D$ were discussed in previous sections. The brine-mixed mortar was included to represent a standard field practice. Naturally-occurring brines are used routinely for mixing cementitious materials for plugging boreholes in evaporites (Wakeley et a.., 1981b).

\subsubsection{Casting and Curing Composites}

Composites in row $B$ of Table 3.5 .2 were cast as pre-placed aggregate concrete. The aggregate was rodded into standard 51X 102-mm bronze molds, the inner surfaces of which had been coated with a Teflon (TM) releasing agent. ASTMmixed grout was slowly poured into each gravel-filled mold, with the molds on a vibrating platform at low speed. After curing in the molds for 48 hours, the cylinders were demolded and transferred to E17 brine at the required curing temperature.

All other composites in this study were prepared as normally mixed concrete, the coarse aggregate mixed by hand into grout or mortar prepared by modified ASTM mixing methods (ASTM C 305, modified by stirring the silica fume, if any, into the mixing liquid before combining the liquid with the other cemenititous components; this modification is necessary due to the very high surface area and surface charging of this material, and is a routine procedure in our laboratory when fumed silica is used). Concretes were tamped into the molds. Mold size and preparation, precure, and other practices were as described above.

Additional samples of most composites were cast in prepared stainless steel sleeves (no releasing agent) of $51 \times 51-m m$. Containing salts, these mixes were expansive enough to seal themselves into these restraining sleeves as they cured. Samples were designed to fit the apparatus for measuring permeability. Use of 
Table 3.5.1. Components of grouts and mortars used for composites with evaporite-sequence aggregate.

A) Brine-mixed grout, 82-08

Component

class H cement

class C fly ash

calcium sulfate

reagent $\mathrm{NaCl}$

plasticizer (D-65)

defoaming agent

E17 brine ( WIPP-B) weight, $g$ Code No.

68.0

22.9

8.34

4.05

1.10

0.04

42.7

(H-09)

(B44)

(A40)

(P05)

(A.50)

(A27)

(E17)
B) NaC1 grout, 81-C81

Same as A), using $29.4 \mathrm{~g}$ deionized $\mathrm{H}_{2} \mathrm{O}$ instead of brine (see section 3.1).

C) NaC1 mortar, 82-14 (see section 3.4)

D) $\mathrm{CaCl}_{2}$ mortar, $82-02$

welght, $g$

48.0

12.0

12.0

8.0

88.0

9.26

$--$

0.80

-

21.6
Component

class H cement class C fly ash class F fly ash silica fume sand (ASTM C-109) reagent $\mathrm{NaCl}$ reagent $\mathrm{CaCl}_{2}$ plasticizer defoamer citric acid deionized water
Code No.

(H-08)

(B15)

(B25)

(B51)

(C38)

(P05)

(P07)

(A41)

(A27)

(P26)

(E01) weight, $g$

48.0

12.0

12.0

8.0

88.0

$=$

17.92

0.80

0.05

0.20

22.5

Table 3.5.2. Combinations of aggregates and cementitious formulations.

$$
\text { dolostone halite anhydrite }
$$
A) brine-mixed grout, 82-08
$X$
B) $\mathrm{NaC1}$ grout, 81-091
C) $\mathrm{NaCl}$ mortar, 82-14
D) $\mathrm{CaCl}_{2}$ mortar, $82-02$
$Y$

$Y$

X $\quad$ X
$\checkmark$
$\mathrm{X}$

$x=$ samples at $38^{\circ}$ and $60^{\circ} \mathrm{C} ; y=$ samples at $38^{\circ} \mathrm{C}$. 
E17 brine as the permeating fluid for these composites avoided much dissolution of water-soluble components.

Cylinders of each mix were cured at $38^{\circ} \mathrm{C}$ until the desired test date. Additional cylinders of both salt-mortar concretes, of brine-grout concrete with dolostone aggregate, and of $\mathrm{CaCl}_{2}$-mortar concrete were cured at $60^{\circ} \mathrm{C}$ (see Table 3.5 .2 ).

\subsubsection{Testing Composites: Methods and Results}

The first focus of the studies of these cement/rock materials was the strength of the composites. Compressive strength of the cylinders, measured according to ASTM C 39, indicates in a relative way the strength of the bonds between grout or mortar and rock. Of course the measured strength value depends on many factors. Sample size and shape; the strength of the cured mortar and the rock individually; the shape and distribution of aggregate particles; and testing-machine settings all affect the quantification of compressive strength. The variables were minimized by using one sample size, one range of aggregate size, etc., and one operator to complete these tests. Values for compressive strength of grout concretes (A and B above) and mortar concretes ( $\mathrm{C}$ and $\mathrm{D}$ above) are given in Table 3.5.3.

Bulk density was measured and porosity calculated for some composites on material derived from the cylinders after compression testing. Samples of the cured grout or mortar fraction of each composite were prepared for $\mathrm{x}-\mathrm{ray}$ powder diffraction, ground and sieved to -100 mesh. Some samples were mounted for study as a slurry with collodion; most were packed dry into specially made sample holders in an attempt to avoid preferred grain orientation. Table 3.5.4 lists bulk density values. Crystalline phases identified by $x$-ray diffraction are essentially the same as those recognized in diffraction patterns from the mortars or grouts alone (see section 3.1 for discussion of phase composition relative to curing time and temperatures). Samples of brine-mixed grout containing dolostone aggregate also included $\mathrm{Ca}(\mathrm{OH})_{2}{ }^{\circ}$

Thin sections were prepared for optical microscopy of NaCl grout and mortar with dolostone aggregate. After one month of curing, the grouted dolostone showed an extensive zone of crystal growth at the interface between grout and rock. This zone was not obvious in the mortar concrete, although the contacts were continuous. [The latter sample had been cured in a $\mathrm{Ca}(\mathrm{OH})_{2}$ solution, not in brine as had the others, so we had not expected the interaction to be the same.]

Permeabilities to brine were tested for many of the composites. In general, 
Table 3.5.3. Compressive strength (MPa) measured for composites with $\mathrm{NaCl}$ and $\mathrm{CaCl}_{2}$.

\begin{tabular}{llll}
\multicolumn{4}{c}{ curing time* (days) } \\
\hline 7 & 14 & 28 & 56
\end{tabular}

A) brine-mixed grouts

82-02 do1

82-08 hal

B) NaC1 grout

81-081 do 1

81-081 anh

C) $\mathrm{NaCl}$ mortar

82-14 dol

82-14 hal

D) $\mathrm{CaCl}_{2}$ mortar

82-02 dol

$\begin{array}{rrr}17.2 & 31.6 \\ & 30.3\left(60^{\circ}\right) \\ 9.4 & 9.5\end{array}$

10.8

26.120 .0

21.3

38.2

28.6

25.1

21.9

$30.3\left(60^{\circ}\right)$

14.0

$11.7\left(60^{\circ}\right)$

13.3

24.5

$22.4\left(60^{\circ}\right)$

*in $\mathrm{E} 17$ at $38^{\circ} \mathrm{C}$ unless other temperature noted.

do1 = dolostone aggregate; hal = halite aggregate; anh = anhydrite aggregate. 
Table 3.5.4. Bulk density $(\mathrm{g} / \mathrm{cc})$ and porosity of composites.

dolostone halite
A) brine-mixed grout, 82-08
$2.10 \quad(14 d) *$
1.75 (14d)
B) NaC1 grout, $81-081$
0.178
0.204
$2.16(14 d)$
C) NaC1 mortar, 82-14
0.172
2.11 (7d)
0.135
D) $\mathrm{CaCl}_{2}$ mortar, 82-02
2.25 (7d)
0.125

*values differed very little at $28 d$.

Table 3.5.5. Measured permeability of concrete composite samples ( $38^{\circ}$ curing)

\begin{tabular}{ccc}
\hline composite type & age (days) & $\begin{array}{c}\text { average permeability } \\
\text { (darcy, } \mu \mathrm{m}^{2} \text { ) }\end{array}$ \\
\hline NaC1 grout + dolostone & 14 & $4.3 \times 10^{-7}$ \\
$81-081$ & 28 & $4.0 \times 10^{-7}$ \\
& 56 & $<10^{-8}$ \\
NaC1 grout + anhydrite & 90 & $8.2 \times 10^{-7}$ \\
$81-081$ & 28 & $<10^{-8}$ \\
& 56 & $7.8 \times 10^{-8}$ \\
brine grout + halite & 90 & $6.9 \times 10^{-8}$ \\
& & (failed) \\
\hline
\end{tabular}


the values for permeability of these samples approached those of the aggregate included in them. This indicated no preferred flow pathways along grout/rock interfaces, although the aggregates were not necessarily in grain-to-grain contact except in samples with pre-packed aggregate (row B in tables). Table 3.5.5 is a summary of measured permeability values.

\subsubsection{Special Combinations of Cements and Rocks}

In addition to the concrete-type composites described above, we have also designed and tested another type of sample, which permits measurement of flow at the interface between mortar or grout and rock (Wakeley and Roy, 1982b). The rock which is the focus of interest is cut into slabs the thickness of the desired finished sample. Using a drill press with a coring bit, cylinders of the diameter of the desired test specimen were cut from the slab. Either oil or water is appropriate for cooling during sawing and drilling, depending on the rock type in question (we used oil for evaporite rocks).

To create the surface that will become the interface, cut the rock cylinders or discs in half by cutting parallel to the side walls of the cylinder, splitting. the circumference from top to bottom of the cylinder. If the diameter is greater than the height, and rock specimens thus disc-shaped, this is like splitting an aspirin tablet. Seal each half-cylinder of rock with epoxy into a sleeve or ring tooled to the required inside diameter. Avoid applying epoxy to any surface of the rock other than curved surface in contact with the sample sleeve. It plugs the pores and changes the effective pressurized area. We have used brass and stainless steel sleeves.

After the epoxy has cured, interface samples are created by filling the empty halves of the rings with the desired grout or mortar. The interface is then planar and parallel to the pressurized flow, if any. We have used this configuration with dolostone and anhydrite in contact with NaC1 grout (Table 3.5.1, B). The values obtained were compared to permeabilities of grout and rock individually. We assumed that if the grout/rock interface provided a preferred flow path, the permeability values obtained would be greater than values measured for either grout or rock. Experimentally rapid flow (on the order of $10^{-3}$ darcy or greater) was assumed to represent sample failure, either from epoxy failure, or from shrinkage of the mortar.

All groups of samples gave permeability values in line with those of their components individually. By this method, we have determined that the interface 
between these rock types and some specially designed cementitious mixes does not provide a preferred pathway for water flow (Wakeley and Roy, 1982b). Permeability values for rocks are given in Table 2.2.3; those of interface samples are given in Table 3.5.6.

\section{5 .6 Summary}

In general, the concrete composites with the highest strength and lowest porosity are those including dolostone aggregate. Strength at 28 days is not strongly affected by temperature $\left(38^{\circ} \mathrm{vs} .60^{\circ}\right)$. Of the grout-based composites, those mixed with brine and 81-081 matrix achieved higher strength at 28 days than do the others, the latter surpassing them with longer curing times. The CaCl${ }_{2}$ mortar samples gain strength slowly, but at 28 days they are comparable to the $\mathrm{NaCl}$ grout with either dolostone or anhydrite. At longer curing times, the $\mathrm{CaCl}_{2}-$ containing samples lose strength through self-cracking, but the presence of coarse aggregate seems to mitigate strength loss. This is true to some extent for all composites. The strengths attained and low porosities and permeabilities of these composites suggest that under confined curing their behavior would be improved.

Table 3.5.6. Measured permeability: interface samples.

\begin{tabular}{ccc}
\hline sample type & $\begin{array}{c}\text { age } \\
\text { (days) }\end{array}$ & $\begin{array}{c}\text { permeability } \\
\text { (darcy, } \mu \mathrm{m}^{2} \text { ) }\end{array}$ \\
\hline $\begin{array}{c}\text { NaCl grout }(81-081)+ \\
\text { dolostone }\end{array}$ & 56 & $2.6 \times 10^{-7}$ \\
NaCl grout (81-081) & 120 & $1.4 \times 10^{-6}$ \\
anhydrite & 120 & $<10^{-8}$ \\
\end{tabular}


4 EARTH MATERIALS

\subsection{INTRODUCTION}

Clay minerals and mixtures of clays with other materials have been proposed as a major backfill material in radwaste repositories and their adjoining shafts primarily for the sealing properties and their ability to adsorb large amounts of radionuclides from solution (D'Appolonia, 1980b, DOE, 1980). Clay minerals that expand in the presence of water have received much attention as a potential means of sealing a borehole, especially at the rock-seal interface, thereby effectively reducing fluid flow (Pusch, 1978; Pusch et a1., 1980). At the same time, the ability of these clays to adsorb various radionuclides has attracted its proponents for inclusion in the backfill area of a repository.

Despite the attractiveness of clay minerals as an effective sealant, it is recognized that the ability to attain an effective seal with clays is not nearly as feasible as with many impermeable concretes. Therefore the attention on clay minerals has shifted from short-term clay function to that of stability and longevity in the repository environment (D'Appolonia, 1980a). While clay minerals may not provide as effective a seal as many concretes, it is expected that because they are natural materials, still relatively close to their conditions of formation, that certain clays can persist for very long periods of time, providing the long-term seal required for radioactive waste repositories. Most clay minerals form at or very near the earth's surface, which is reflected primarily by their hydrous nature, and have been observed to persist for long periods of time under diagenetic, low-grade metamorphic conditions.

It is possible that proper emplacement methods reduce the differences in physical and chemical behavior between clay types, such that with sufficient forethought a satisfactory seal can be produced from virtually any clay or mixture of clays. The overriding concern is that of stability and longevity of these varlous clay minerals under repository conditions, for diagenetic changes in the chemistry and structural configuration of the clays have profound effects on their sealing properties. Along with the considerations of stability it is very important to determine the rates at which these clays will transform: a clay mineral outside its stability field may nonetheless alter so slowly that it retains its essential properties for the anticipated lifetime of the repository seal.

The same concerns may be raised about the potential use of zeolites in repository room and tunnel backfill. Because of their high sorptive capacities 
for many cations including fission products and actinides, their potential use is considered primarily for this purpose, rather than for their capacity to restrict water movement.

Specific questions of longevity for these two main types of earth materials, the rates at which alteration can take place, and the effects on their properties are being addressed. Natural analog mineral occurrences are synthetic laboratory experiments are principal means of study.

\subsection{NATURAL ANALOGS--CLAY MINERALS IN SALT}

The occurrence of clay minerals in various types of evaporite deposits reflects both the influence of original mineralogy due to source and distribution along with post-depositional diagenetic alteration and neoformation reactions. Stability relationships among clay minerals deposited within these hypersaline environments have been determined primarily by earlier studies on mineral identification (characterization), while detailed geochemical work on the clays has lagged behind. Despite the unevenness of available data, several generalizations regarding the relative stability of common clay minerals can be inferred from the abundant, if somewhat dated, geological descriptions of clays in evaporites (see Droste, 1963; Millot, 1970, for reviews). One of the problems of using older studies is that perceptions of interstratified clays and methods for their characterization have changed considerably over the past 20 years.

Distribution of clay minerals in evaporite deposits of various ages mirrors the overal1 clay mineral distribution through time (Weaver, 1958; Droste, 1963). Carboniferous and older deposits contain a predominantly illite and chlorite assemblage while younger evaporites include smectite, and lesser amounts of chlorite. It is still uncertain as to whether this distinctive distribution of clays through time in both "normal" shale and evaporite reflects a change in provenance around Carboniferous time or is due to rate-controlled postdepositional diagenetic processes.

One problem requiring resolution is whether the clay minerals observed in evaporites are detrital in origin, precipitates from solution and deposited on the sediment surface, or authigenic precipitates that form within the interstitial voids after deposition. The cases of neoformational precipitation satisfy certain requirements for chemical equilibrium and thereby suggest a stable assemblage with the surrounding evaporite. On the other hand, even if a detrital 
clay mineral flake is not in chemical equilibrium with the evaporite its continued persistence for hundreds of millions of years suggests a certain degree of long-term metastability. Nevertheless, it would be nice to resolve the question of detrital vs. authigenic origin for the clay minerals in evaporites inasmuch as it may provide some insight into alteration and preciptation mechanisms.

Clay minerals occur in evaporites as part of "mud seams," "clay partings," or "shale breaks." These layers contain only 10-35\% true clay minerals, while the rest of the fine-grained material consists of dolomite, quartz, feldspars and other less common minerals (Droste, 1963). The origin of these clay seams may either result from deposition onto shallow-water sabkha deposits which is a commonly observed phenomenon in recent shallow-water evaporites, or from the slow accumulation of insoluble residues during pressure solution, as commonly seen in carbonates.

Along with the illites and chlorites that dominate the clay seams in Paleozoic evaporite deposits, random mixed-layer clays, corrensite, talc, and vermiculite have also been identified. Since most of these geologic studies pre-date the recent developments in mixed-layer clay identification it is unclear as to the type of mixed-layering present in many of these samples. It is presumed that in these studies that random mixed-layer clays are identified solely by non-integral basal spacing. These unspecified randomly interstratified clays are observed in the Salina Formation of the Michigan Basin (Droste, 1963; Lounsbury, 1963), the Paradox Basin, the Salado Formation of New Mexico (Droste, 1963), and the Permian salts of the Zechstein Basin (Fuchtbauer and Goldschmidt, 1959). Corrensite, a regularly interstratified chlorite-smectite, is present in salt deposits of Western Canada and the Permian Salado Formation of New Mexico (Droste, 1963; Grim et a1., 1960; Wakeley et a1., 1981a). In the Salado the corrensites are associated with the sylvite and other $\mathrm{K}$-bearing ores (Grim et a1., 1960). Vermiculite is identified along with interstratified illite-smectite in the Paradox Basin while talc is recognized in anhydrite beds in the Zechstein.

Smectite is a major clay mineral in Tertiary salt deposits. Usually it is referred to as montmorillonite, but there is no indication whether previous workers implied a dioctahedral expanding clay as in current nomenclature or were using montmorillonite as a generic term for all $17 \AA$ expanding clays. The 
di- or trioctahedral character of the interbedded smectites would be expected to shed additional light upon alteration reactions and stability relationships. Smectites are found in numerous desert basins in California and Nevada of which Searles Lake is probably the most intensively studied. Illite is the other major clay mineral found in Searles Lake drill holes, far exceeding the minor amounts of chlorite and kaolinite. Clay seams in the Miocene-P1iocene lacustrine borate deposits of California are also dominated by smectite, with lesser amounts of illite and kaolinite (Droste, 1963).

Regardless of the clay mineral assemblage, virtually all of these studies emphasize a detrital origin for the clay minerals, with minimal post-depositional alteration. Occasional minor constitutents, such as talc, are believed to be authigenic. A detrital origin is supported by observable source areas, whether derived by weathering from nearby pelitic rocks or like much of the smectite formed from volcanic ash. Many of these studies also pre-date much of the recent advances in diagenesis research, such that their interpretation of clay minerals in evaporites is essentially one of minor chemical readjustment once deposited, e.g., reconstruction of "degraded" weathering products, and relative long-term stability.

More recent studies on clay minerals in evaporites which have utilized more detailed geochemical and mineralogical data suggest greater mineral reactivity within the diagenetic environment. Chlorites in the Silurian Retsof Formation of New York are higher in Mg and Si than composite "shale" chlorites which lead the authors to assume an authigenic origin (Bodine and Standaert, 1977). The homogeneity in chlorite analyses for several separate flakes suggests that the chlorite precipitates out of the hypersaline solution and is deposited (hyperhalmyrolysis) rather than diagenetic reconstitution of degraded detrital chlorites. The few analyses of other evaporite chlorites available also indicate a high-Mg clinochlore variety (Bodine and Standaert, 1977).

In contrast, the compositional heterogeneity between illite flakes in the Retsof Formation indicates diagenetic transformation ("metasomatic recrystallization") of detrital micaceous clays. These illites are also compositionally distinct from "shale illites" in that they have high tetrahedral Al, which would influence layer charge, and a high interlayer $K$ content. The variability in the illite compositions suggests that equilibrium between the clays and interstitial brines has not been reached. Most of the compositional changes in the clays are 
believed to have occurred early in the burial history, since they assume that the brine composition is constant through time, while later-stage diagenetic effects are restricted to "increasing crystallinity" (Bodine and standaert, 1977). If brine compositions do vary through time, especially on a micro environment scale that chemical alteration need not be restricted to early diagenesis.

The clay minerals in the Salado Formation in the Permian Basin of New Mexico also indicate diagenetic alteration. The overlying shales and siltstones of the Dewey Lake redbeds are predominantly composed of interstratified illitesmectite which is $85 \%$ smectite layers (Wakeley et a1., 1981a). In contrast are the regularly interstratified chlorite-smectites, or corrensites, that are found in the halite and sylvite beds (Grim et al., 1960; Wakeley et al., 1981a). These corrensites consist of 40\% chlorite layers, and $60 \%$ smectite layers that are regularly intercalated with each other. The interpretation of these corrensites is that they are diagenetic transformation products of the original illite-smectite clays. The mechanism of transformation has yet to be deciphered as to whether smectite or illite or both types of layers are reacting with the brines and forming chlorite.

Geochemical studies of clay mineral stability indicate that chlorites and illites would be the relatively more stable clay assemblage at the expense of smectites in highly saline evaporite fluids. Activity diagrams of $\mathrm{MgO}, \mathrm{K}_{2} \mathrm{O}$, and $\mathrm{H}_{4} \mathrm{SiO}_{4}$ systems indicate that in solutions of increased salinity and higher $\mathrm{K}$ and $\mathrm{Mg}$ activities that micas and chlorites are stable relative to smectites (Figure 4.2.1: Kastner and Siever, 1979). The effect of increased salinity is also apparent in natural analogs where in the Paris Basin, illite-smectites are found on the edge of the basin while corrensites populate the basin center, reflecting an increase in salinity during progressive desiccation (Millot, 1970). The smectites are thermodynamically unstable with respect to illites and chlorites in highly saline waters at room temperature, and even more so as temperature increases. The occurrence of detrital smectites in recent evaporites reflects the very slow rates of diagenetic transformations at surface temperatures.

The conclusion is that smectites are unstable in an evaporite system with high salinity interstitial fluids, and alter to illite or chlorite depending upon the actual fluid activity. The rates of these transformations appears to be slow, millions of years at low temperatures, though actual rate constants have not been determined. 

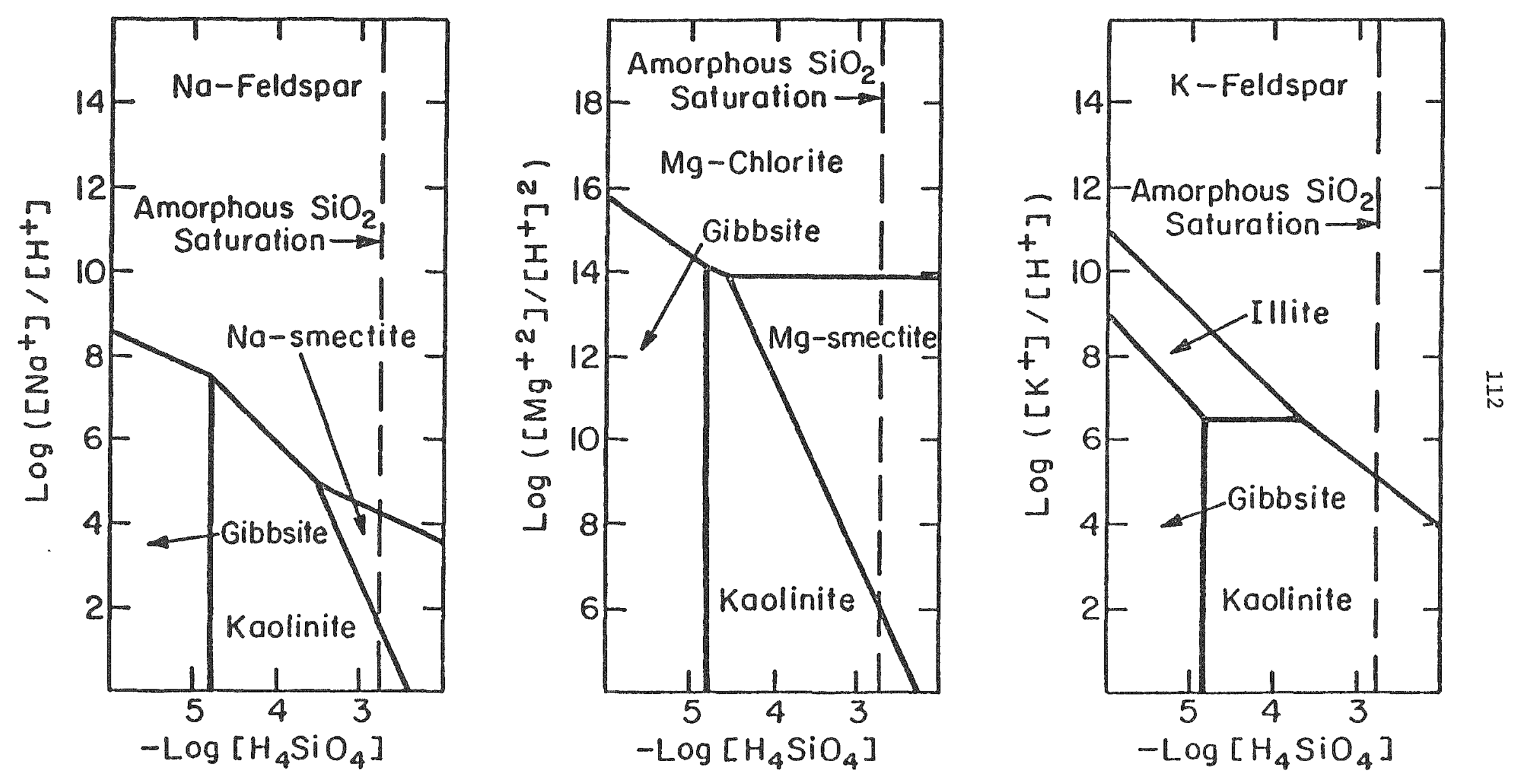

Figure 4.2.1. Stability relationship diagrams for several common low-temperature clay minerals calculated for the activity of several cations $\left(\mathrm{K}^{+}, \mathrm{Na}^{+}, \mathrm{Mg}^{+2}, \mathrm{H}^{+}\right)$against silica activity (after Garrels and Christ, 1965). 


\subsection{ALTERATION OF CLAY MINERALS AND ZEOLITES IN BRINES AT \\ ELEVATED TEMPERATURES AND PRESSURES}

\subsubsection{Introduction}

Clay minerals and zeolites are candidate seal materials for any nuclear waste repository located in geological formations. While clays may be used in primary seals, both clays and zeolite minerals may be constituents of backfill: that material used to fill boreholes, mine shafts and tunnels of a repository when the repository is sealed. Backfill is also a component of the waste package in a multibarrier system of nuclear waste disposal. The primary functions of various types of backfill are as follows: a) to minimize or exclude the migration of ground water between the host geology and the waste canister system, b) to control the Eh, $\mathrm{pH}$ and chemical composition of the ground water within the repository environment, and c) to retard the migration of waste elements in the ground water. The 1ist of potential backfills include expanding clays such as sodiun or calcium bentonite (montmorillonite), natural and/or synthetic zeolites, desiccants such as $\mathrm{CaO}$ and $\mathrm{MgO}$, quartz sand mixed with bentonite, powdered metals, etc. These backfills may be used singly or in combination and the nature of the backfill varies with the geological formation.

In a salt repository, geochemical and thermodynamic interactions of the rock, backfill and water may take place during the thermal period (Cohen, 1977). These interactions may take place under hydrothermal conditions if water intruded into the mined repository during the thermal period. If the sorptive backfill minerals alter by interaction with brine, prior to leakage of radioactive ions, the very purpose of using them may be lost. Therefore, the potential alteration of backfill minerals in brines of a salt repository have been investigated under certain elevated temperature conditions. These are closed-system type experiments in which the solid-1iquid reactivity was investigated. Intrinsic variables such as Eh and pH varied with the bulk chemical composition and temperature conditions. These experiments of short duration will provide trends in the alterations of backfill barriers.

\subsubsection{Experimental}

Materla1s. Ten different backfill samples of clay minerals and zeolites were used in the present study. The sources and/or locations and particle sizes of these backfill samples are given in Table 4.3.1. 
Table 4.3.1. Names, locations, sources, particle sizes of potential backfill samples.

Na-montmorillonite. Wyoming (WY). Source Clays Repository, The Clay Minerals Society. Pulverized.

Ca-montmorillonite. Texas (TX). Source Clays Repository, The Clay Minerals Society. Pulverized.

Vermiculite. Poole property, Enoree, South Carolina (SC). Zonotlite Divison, W.R. Grace and Company. 50-177 $\mu \mathrm{m}$.

Philipsite. Pine Valley, Nevada (NV). Reference zeolite 27154. Minerals Research, PO Box 591, Clarkson, New York 14430. <75 $\mu \mathrm{m}$.

Mordenite. Union Pass, Arizona (AZ). Reference zeolite 27134. Minerals Research, Po Box 591, Clarkson, New York 14430. <75 $\mu \mathrm{m}$.

Mordenite. Levelock, Nevada (NV). Reference zeolite 27144. Minerals Research, PO Box 591, Clarkson, New York 14430。<75 $\mu \mathrm{m}$.

Clinoptilolite. Castle Creek, Idaho (ID). Reference zeolite 27034, Minerals

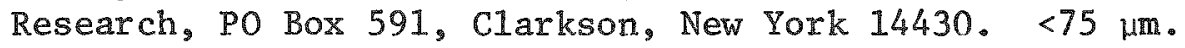

Clinoptilolite. Hector, California (CA). Reference zeolite 27024. Minerals

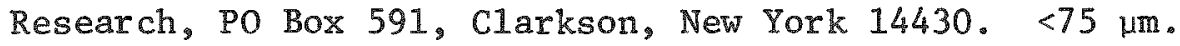

Erionite. Shoshone, California (CA). Reference zeolite 27104. Minerals Research, PO Box 591, Clarkson, New York 14430. <75 um.

Chabazite. Christmas, Arizona (AZ). Reference zeolite 27124. Minerals Research, PO Box 491, Clarkson, New York 14430。<75 $\mu \mathrm{m}$. 
Methods. The montmorillonites were pulverized and homogenized by the supplier. The vermiculite sample was wet ground in a blender and sieved to obtain 50-177 $\mu \mathrm{m}$ size fraction. The zeolites were supplied as -200 mesh ( $<75 \mu \mathrm{m})$ powders. X-ray diffraction (XRD) analysis of dried suspendions of the untreated samples was carried out with a Philips diffractometer using Ni-filtered CuKa. radiation.

To simulate the interactions of brine with backfills in a salt repository, $100 \mathrm{mg}$ of each backfill mineral was loaded into a gold capsule, $200 \mu 1$ of a $\mathrm{Mg}-$ rich brine (designated as NBT-6a brine and composed of $10 \% \mathrm{MgCl}_{2}, 10 \% \mathrm{CaCl}_{2}, 5 \%$ $\mathrm{KCl}, 5 \% \mathrm{NaCl}$, and $70 \% \mathrm{H}_{2} \mathrm{O}$ ) or saturated $\mathrm{NaCl}$ brine were added, sealed (Komarneni et al., 1979) and treated hydrothermally in autoclaves at $200^{\circ}$ and $300^{\circ} \mathrm{C}$ for 4 and 12 (a few runs) weeks under a confining pressure of $30 \mathrm{MPa}$. The $\mathrm{Mg}-\mathrm{rich}$ brine and $\mathrm{NaCl}$ brine used here are similar to the brines for Waste Isolation Pilot Plant (WIPP) experimentation, WIPP ' $A$ ' and WIPP ' $B$ ' brines, respectively (Nowak, 1980).

After the hydrothermal treatment, the gold capsules were weighed to check for the integrity of these closed-system type experiments. The gold capsules devoid of any leaks were cut and opened with a scissors in a glass vial, $25 \mathrm{ml}$ of distilled water were added while washing the scissors, then the gold capsules with samples were shaken to free the sample from the gold capsule. The gold capsule, free of sample, was removed from the vial, the solid and solution phases were separated by centrifugation and the solutions were analyzed for Si and Al by atomic emission spectroscopy (AES) using a computer interfaced SpectraMetrics SpectraSpan III instrument. The solid samples were washed free of excess salts with water and $95 \%$ acetone, dried in an oven at $45^{\circ} \mathrm{C}$ and subjected to XRD analysis to determine the mineralogical alterations by the hydrothermal treatments.

The XRD detection limit is too high to detect minor alterations in the cation exchangers. A more sensitive way to detect alteration is probably a total cation exchange or a selective cation sorption measurement. Total cation exchange measurements are somewhat time-consuming and not as relevant as selective cation sorption measurements in the case of a salt repository. Therefore, selective cation sorption measurements were made in this study. Selective Cs and Sr sorption is defined here as the partial uptake of $\mathrm{Cs}$ and $\mathrm{Sr}$ from a $0.04 \mathrm{~N} \mathrm{NaNO}_{3}$ solution. Twenty-five milliliters of $0.04 \mathrm{~N}^{\mathrm{NaNO}} 3$ solution containing $0.0002 \mathrm{~N} \mathrm{CsCl}$ and $0.0002 \mathrm{~N} \mathrm{SrCl}_{2}$ was added to the untreated or hydrothermally altered samples, 


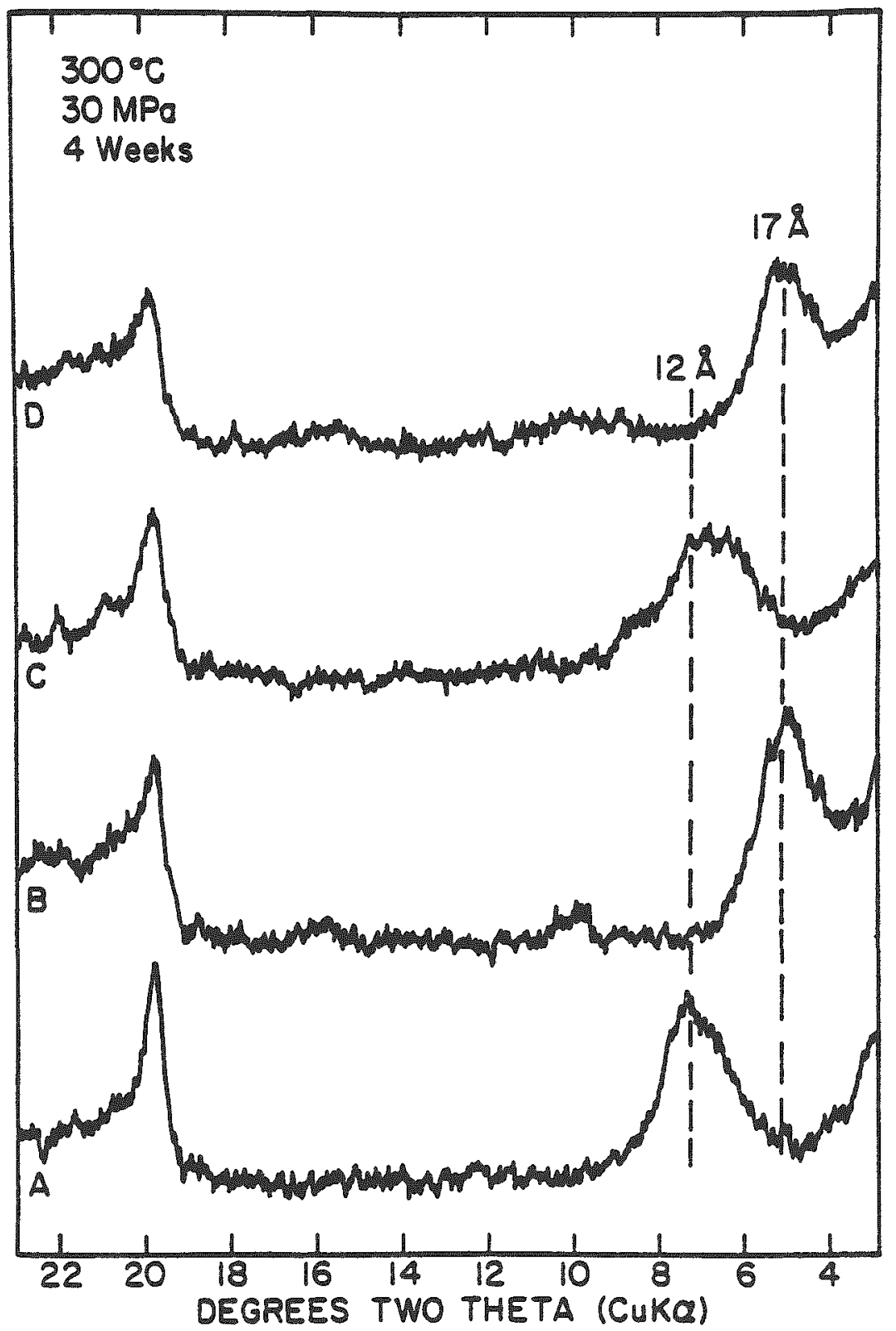

Figure 4.3.1. X-ray powder diffractograms of hydrothermally altered zeolites in $\mathrm{Mg}-\mathrm{rich}$ brine. A) Phillipsite from Nevada altered to $12 \AA$ clay mineral; B) same as A) but expanded to $17 \AA$ upon exposure to ethylene cylcol which indicated that it is smectite; C) chabazite, Arizona, altered to $\sim 12 \AA$ clay mineral; $D)$ same as C) but expanded to $17 \AA$ upon exposure to ethylene glycol which indicated that it is smectite. 
and the mixtures were equilibrated for 24 hours at $25^{\circ} \mathrm{C}$. The solid and solution phases were separated by centrifugation. The amounts of Cs and Sr adsorbed were estimated by determining the $\mathrm{Cs}$ and $\mathrm{Sr}$ remaining in solution. Cesium in solution was determined by atomic absorption spectrophotometry (A1S) using a Perkin Elmer PE703 instrument with electrode-1ess discharge lamp. Strontium in solutions was determined by AES.

\subsubsection{Results and Discussion}

Alterations of Clay Minerals and Zeolites in Saturated NaCl Brine. The mineralogical alterations of clay minerals and zeolites under hydrothermal conditions of $200^{\circ}$ and $300^{\circ} \mathrm{C}$ in $\mathrm{NaCl}$ are presented in Table 4.3.2. At $200^{\circ} \mathrm{C}$, no alteration of the two montmorillonites and vermiculite could be detected in hydrothermal NaCI brine by XRD. Among the zeolites, phillipsite completely altered to analcime while erionite altered only slightly in this brine at $200^{\circ} \mathrm{C}$ (Table 4.3.2). No mineralogical changes could be detected with mordenites, clinoptilolites and chabazite $\mathrm{NaCl}$ brine at $200^{\circ} \mathrm{C}$. At $300^{\circ} \mathrm{C}$, only the montmorillonite from Texas seemed to be altering to albite (Figure 4.3.2), but not the other montmorillonite. Albite may have formed by the reaction of the amorphous component in this montmorillonite with NaC1. Vermiculite did not seem to change in this brine even after treatment at $300^{\circ} \mathrm{C}$. Most of the zeolites seem to be altering to albite via analcime. In fact, this type of alteration has been reported earlier (Surdam, 1977; Boles, 1977). This is not surprising because the structures of zeolites are similar to those of feldspar (Breck, 1974). Mordenites which are more siliceous than the other zeolites seem to be somewhat resistant to alteration (Breck, 1974).

Specific Sorption of Cs and Sr by Minexals Altered Hydrothermally in NaCI Brine. Clay minerals and zeolites specifically sorb ions such as $\mathrm{Cs}$ and $\mathrm{Sr}$ (Komarneni and Roy, 1980) and therefore, their alteration can also be detected by a change in their selective ion sorption properties. Specific sorption of Cs and $\mathrm{Sx}$ by the various hydrothermally altered minerals is given in Table 4.3.3. Selective Cs sorption decreased only in the case of phillipsite among all the minrals which were hydrothermally treated at $200^{\circ} \mathrm{C}$. This is because phillipsite, an open zeolite, altered to the non-porous analcite (Table 4.3.2) which does not easily exchange its cations. The $\mathrm{Cs}$ sorption $\mathrm{K}_{\mathrm{d}}$ decreased from 11,700 in the 
Table 4.3.2. X-ray diffraction analyses of untreated and hydrothermally altered minerals.

\begin{tabular}{|c|c|c|c|c|c|}
\hline \multirow{2}{*}{ Sample } & \multirow{2}{*}{$\begin{array}{l}\text { Minerallogy of } \\
\text { untreated } \\
\text { samples }\end{array}$} & \multicolumn{2}{|c|}{ Mineralogical changes in saturated $\mathrm{NaCl}$ brine } & \multicolumn{2}{|c|}{ Mineralogical changes in Mg-rich brine } \\
\hline & & $200^{\circ} \mathrm{C} / 30 \mathrm{MPa}$ & $300^{\circ} \mathrm{C} / 30 \mathrm{MPa}$ & $200^{\circ} \mathrm{C} / 30 \mathrm{MPa}$ & $300^{\circ} \mathrm{C} / 30 \mathrm{MPa}$ \\
\hline Montmorillonite, wY & $\begin{array}{l}\text { Montmorillonite, quartz, } \\
\text { albite, mica and calcite }\end{array}$ & No obvious change & No obvious change & No obvious change & No obvious change \\
\hline Montmorillonite, TX & $\begin{array}{l}\text { Montmorilionite, cristoba- } \\
\text { lite, quartz, } \mathrm{K} \text {-feldspar } \\
\text { and talc }\end{array}$ & No obvious change & $\begin{array}{l}\text { Slightly altered } \\
\text { to albite }\end{array}$ & No obvious change & $\begin{array}{l}\text { Cristobalite formed; } \\
\text { randomly interstratified } \\
\text { montmorillonite/illite } \\
\text { formed }\end{array}$ \\
\hline Vermiculite, SC & Vermiculite & No obvious change & No obvious change & $\begin{array}{l}\text { Some randomly inter- } \\
\text { stratified vermiculite/ } \\
\text { mica }(12.56 \AA) \text { formed }\end{array}$ & Collapsed to form mica \\
\hline Phillipsite, NV & Phillipsite & $\begin{array}{l}\text { Completely altered } \\
\text { to analcime }\end{array}$ & $\begin{array}{l}\text { Completely altered } \\
\text { to albite and } \\
\text { analcime }\end{array}$ & No obvious change & $\begin{array}{l}\text { Smectite and boehmite } \\
\text { formed }\end{array}$ \\
\hline Mordenite, AZ & Mordenite & No obvious change & No obvious change & No obvious change & No obvious change \\
\hline Mordentie, NV & $\begin{array}{l}\text { Mordenite and cristoba- } \\
\text { lite }\end{array}$ & No obvious change & No obvious change & $\begin{array}{l}\text { Some cristobalite } \\
\text { formed? }\end{array}$ & Some cristobalite formed? \\
\hline Clinopeilolite, ID & Clinoptilolite & No obvious change & No obvious change & No obvious change & Some smectite formed \\
\hline Clinoptilolite, CA & Clinoptilolite & No obvious change & $\begin{array}{l}\text { Moderately altered } \\
\text { to albite and } \\
\text { analcime }\end{array}$ & No obvious change & Some smectite forned \\
\hline Erionite, $\mathrm{CA}$ & Erionite and quartz & $\begin{array}{l}\text { Slightly altered } \\
\text { to analcime }\end{array}$ & Albite & No obvious change & $\begin{array}{l}\text { Smectite and unidentified } \\
\text { phase forned }\end{array}$ \\
\hline Chabazite, AZ & Chabazite and quartz & No obvious change & Albite + quartz & No obvious change & $\begin{array}{l}\text { Smectite and quartz (?) } \\
\text { formed }\end{array}$ \\
\hline
\end{tabular}




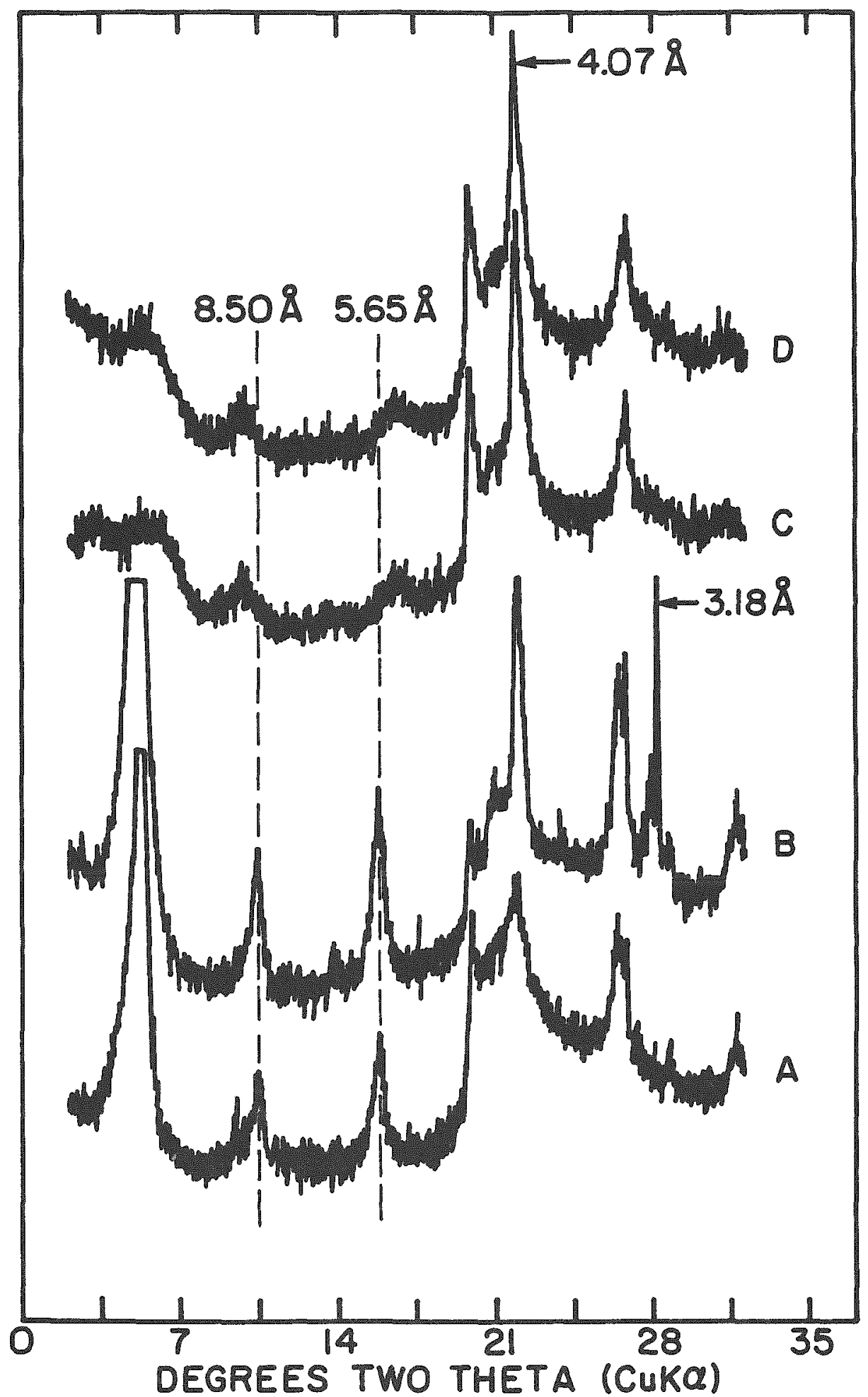

Figure 4.3.2. X-ray powder diffractograms of untreated and hydrothermally altered TX montmorillonite at $300^{\circ} \mathrm{C} / 30 \mathrm{MPa}$. A) untrated; B) altered partially to albite in $\mathrm{NaCl}$ brine after 12 weeks; C) altered to randomly interstratified montmorillonite/111ite after 4 weeks; D) altered to randomly interstratified montmorillonite/ illite after 12 weeks. 
Table 4.3.3. Specific sorption of $\mathrm{Cs}$ and $\mathrm{Sr}$ as affected by the hydrothermal alteration of backfills in saturated NaC1 brine.

\begin{tabular}{|c|c|c|c|c|c|c|}
\hline \multirow{2}{*}{ Sample } & \multicolumn{3}{|c|}{ Cs sorption $\mathrm{K}_{\mathrm{d}}^{1}(\mathrm{ml} / \mathrm{g})$} & \multicolumn{3}{|c|}{$\mathrm{Sr}$ sorption $\mathrm{K}_{\mathrm{d}}{ }^{1}(\mathrm{ml} / \mathrm{g})$} \\
\hline & untreated & $200^{\circ} \mathrm{C} / 30 \mathrm{MPa}$ & $300^{\circ} \mathrm{C} / 30 \mathrm{MPa}$ & untreated & $200^{\circ} \mathrm{C} / 30 \mathrm{MPa}$ & $300^{\circ} \mathrm{C} / 30 \mathrm{MPa}$ \\
\hline Montmorillonite, WY & 410 & 400 & 510 & 170 & 200 & 310 \\
\hline Montmorillonite, TX & 310 & 685 & 740 & 310 & 370 & 370 \\
\hline Vermiculite, SC & 8,900 & 10100 & 990 & 2000 & 980 & 230 \\
\hline Phillipsite, NV & 11700 & 240 & 15 & 460 & 25 & 10 \\
\hline Mordenite, $\mathrm{AZ}$ & 8300 & 9500 & 7900 & 310 & 670 & 400 \\
\hline Mordenite, NV & 6400 & 6700 & 30 & 170 & 370 & 25 \\
\hline Clinoptilolite, ID & 3900 & 4800 & 5000 & 3000 & 6100 & 3500 \\
\hline Clinoptilolite, CA & 5600 & 5600 & 4600 & 4700 & 4700 & 590 \\
\hline Erionite, CA & 9500 & 11700 & 40 & 490 & 590 & 40 \\
\hline Chabazite, $\mathrm{AZ}$ & 6600 & 8900 & 70 & 310 & 400 & 50 \\
\hline
\end{tabular}

$1_{K_{d}}$ is a distribution coefficient and is defined as the ratio of the amount of Cs sorbed per gram to the amount of unsorbed Cs remaining per milliliter of the solution. 
case of untreated phillipsite to 240 in the case of phillipsite treated at $200^{\circ} \mathrm{C}$ because of analcime formation after hydrothermal treatment. With the rest of the minerals, specific sorption either remained the same or increased slightly. The increase of specific sorption by these minerals can be attributed to a change in the nature of the exchangeable ions in these minerals by the hydrothermal treatment in $\mathrm{NaCl}$ brine, i.e., the natural cations such as $\mathrm{K}$, $\mathrm{Ca}$ and $\mathrm{Mg}$ in these minerals were displaced by $\mathrm{Na}$ which competes less with $\mathrm{Cs}$ than either $\mathrm{K}$ or $\mathrm{Ca}$ or $\mathrm{Mg}$ (Ames, 1960, 1961, 1963; Tamura and Jacobs, 1961). Therefore, Cs sorption increased in these minerals which were treated at $200^{\circ} \mathrm{C}$.

Specific Cs sorption increased in both the montmorillonites which were hydrothermally treated in $\mathrm{NaCl}$ brine at $300^{\circ} \mathrm{C}$ for the same reason as given above. Specific sorption of $\mathrm{Cs}$ decreased from $8900 \mathrm{~K}_{\mathrm{d}}$ in the untreated vermiculite to 990 in the vermiculite which altered hydrothermally at $300^{\circ} \mathrm{C}$ probably because of partial chloritization by the hydrolysis of natural $\mathrm{Mg}^{2+}$ in the interlayers. This is a case where XRD did not reveal any mineralogical alteration while specific Cs sorption measurement indicated alteration of this mineral by hydrothermal treatment at $300^{\circ} \mathrm{C}$. Specific Cs sorption decreased (Table 4.3.3) with most of the zeolites which were hydrothermally treated in NaCl brine because of alteration to analcite and or albite. The latter minerals do not undergo cation exchange readily and therefore, Cs sorption decreased. Results of $\mathrm{Sr}$ specific sorption (Table 4.3.3) by the hydrothermally altered minerals closely parallel with those of the Cs sorption and can be explained similarly. Thus, the results of Cs and Sr specific sorption as well as the results of mineralogical alterations revealed by XRD of the hydrothermally altered minerals indicate montmorillonites are more resistant to alteration in NaCl brine than vermiculite or zeolites.

Alterations of Clay Minerals and Zeolites in Mg-rich Brine. The alterations of clay minerals and zeolites in $\mathrm{Mg}-\mathrm{rich}$ brine under hydrothermal conditions are given in Table 3.4.4. Among the clay minerals, montmorillonites do not seem to alter in this brine at $200^{\circ} \mathrm{C}$ as detected by XRD. The vermiculite which has a high total layer charge (Komarneni and Roy, 1978) selectively adsorbed $K$ from the Mg-rich brine (which contained substantial KCI) and transformed to randomly interstratified vermiculite/mica with an average c-axis spacing of $12.56 \AA$. The transformation of vermiculite to mica would decrease the cation exchange capacity and selective ion sorption because interlayer $\mathrm{K}$ from mica is not easily exchangeable. No alteration could be detected by XRD in any of the zeolites which were treated hydrothermally in this brine at $200^{\circ} \mathrm{C}$. 
Table 4.3.4. Concentrations of $\mathrm{Si}$ and $\mathrm{Al}$ in the capsule fluids after hydrothermal treatments.

\begin{tabular}{|c|c|c|c|c|c|c|c|c|}
\hline \multirow{3}{*}{ Sample } & \multicolumn{4}{|c|}{ Saturated NaCl brine } & \multicolumn{4}{|c|}{ Mg-rich brine } \\
\hline & \multicolumn{2}{|c|}{$200^{\circ} \mathrm{C}$} & \multicolumn{2}{|c|}{$300^{\circ} \mathrm{C}$} & \multicolumn{2}{|c|}{$200^{\circ} \mathrm{C}$} & \multicolumn{2}{|c|}{$300^{\circ} \mathrm{C}$} \\
\hline & $\begin{array}{c}S_{i} \\
(\mu g s / m I)\end{array}$ & $\begin{array}{c}\mathrm{AI} \\
(\mu \mathrm{gs} / \mathrm{ml})\end{array}$ & $\begin{array}{c}\mathrm{Si} \\
(\mu \mathrm{gs} / \mathrm{mI})\end{array}$ & $\begin{array}{c}\mathrm{Al} \\
(\mu \mathrm{gs} / \mathrm{ml})\end{array}$ & $\begin{array}{c}\mathrm{Si} \\
(\mu \mathrm{gs} / \mathrm{m} 1)\end{array}$ & $\frac{\mathrm{A} 1}{(\mu \mathrm{gs} / \mathrm{ml})}$ & $\begin{array}{c}\mathrm{Si} \\
(\mu \mathrm{gs} / \mathrm{mI})\end{array}$ & $\begin{array}{c}\mathrm{A1} \\
(\mu \mathrm{gs} / \mathrm{mI})\end{array}$ \\
\hline Montmorillonite, WY & 150 & 35 & 15 & 40 & 60 & 370 & 60 & 290 \\
\hline Montmorillonite, TX & 45 & 25 & $<1.3$ & 35 & 50 & 360 & 80 & 280 \\
\hline Vermiculite, SC & $<1.3$ & $<0.13$ & 30 & $<0.13$ & 25 & 180 & 20 & $<0.13$ \\
\hline Phillipsite, NV & 40 & $<0.13$ & 6 & $<0.13$ & 80 & 360 & 60 & 300 \\
\hline Mordenite, $A Z$ & 35 & 90 & 10 & 120 & 65 & 380 & 40 & 290 \\
\hline Mordenite, NV & 70 & 40 & 30 & 80 & 35 & 370 & 50 & 280 \\
\hline Clinoptilolite, ID & 15 & 1 & 15 & 15 & 65 & 350 & 35 & 270 \\
\hline Clinoptilolite, CA & 50 & 15 & $<1.3$ & 40 & 60 & 360 & 50 & 285 \\
\hline Erionite, CA & 70 & 45 & 60 & 95 & 65 & 380 & 60 & 310 \\
\hline Chabazite, $A Z$ & 25 & 30 & $<1.3$ & 120 & 80 & 380 & 60 & 320 \\
\hline
\end{tabular}


Montmorillonite from Texas seems to be altering slightly in the Mg-rich brine at $300^{\circ} \mathrm{C}$ by forming mainly cristobalite and randomly interstratified montmorillonite/illite (Eberl et al., 1978) (Figure 4.3.2, Table 4.3.4). On the other hand, montmorillonite from Wyoming did not seem to alter by hydrothermal treatment at $300^{\circ} \mathrm{C}$ for 4 weeks (Table 4.3.4) or even after 12 weeks. The difference in reactivity between the two montmorillonites is not clear but may be attributed to a difference in the chemical composition (Van Olphen and Fripiat, 1979). The high charge vermiculite collapsed to form mica by selective uptake of $\mathrm{K}^{+}$ions from the Mg-rich brine. Most of the zeolites altered to montmorillonite (Table 4.3.2, Figure 4.3.2) in the presence of $\mathrm{Mg}-\mathrm{rich}$ brine as a result of acidic conditions generated by the hydrolysis of $\mathrm{Mg}$ to form brucite (Komarneni, 1981), $\mathrm{H}^{+}$saturation of zeolite and decomposition of the zeolitic framework, followed by recrystallization to form smectite. Experiments are presently under way to test this hypothesis of smectite formation. Acidic $\mathrm{pH}$ develops in highly saline solutions at elevated temperatures because of changes in hydrolysis constants and the association of ion pair complexes and the pH may go down to about 3 in $\mathrm{Mg}-$ rich brine at $300^{\circ} \mathrm{C}$ (Claiborne et a1., 1980; Braithwaite and Molecke, 1980). There is indirect evidence for the development of acidic conditions in the Mg-rich brine as revealed by the release of substantial concentrations of Al into solution (Table 4.3.4) when these minerals were treated in the brines. More Al was released in the Mg-rich brine than in the NaCl brine under these hydrothermal conditions because the Mg-rich brine is much more acidic than the $\mathrm{NaCl}$ brine (Braithwaite and Molecke, 1980). On the other hand, when these backfills were treated under hydrothermal conditions the concentrations of $S i$ in solution are very low in the acidic hydrothermal brines (Table 4.3.4) because silica is less soluble in acidic conditions.

Specific Sorption of $\mathrm{Cs}$ and $\mathrm{Sr}$ by Minerals Altered Hydrothermally in $\mathrm{Mg}$-rich Brine. The specific sorption of $\mathrm{Cs}$ by all the minerals excepting montmorillonite decreased (Table 4.3.5) because of mineralogical alterations (Table 4.3.2) and/or change in the negative charge balancing ions in these minerals treated hydrothermally at $200^{\circ} \mathrm{C}$. For example, $\mathrm{K}^{+}$was selectively sorbed from the Mg-rich brine by the vermiculite and collapsed to form mica which is randomly interstratified with vermiculite at this temperature. Formation of mica led to a decrease in the specific Cs sorption because interlayer ions in mica are not easily exchangeable. Zeolites are also selective for $\mathrm{K}^{+}$ions (Ames, 1961) and 
Table 4.3.5. Specific sorption of $\mathrm{Cs}$ and $\mathrm{Sr}$ as affected by the hydrothermal alteration of backfills in Mg-rich brine.

\begin{tabular}{|c|c|c|c|c|c|c|}
\hline \multirow{2}{*}{ Sample } & \multicolumn{3}{|c|}{ Cs sorption $K_{d}{ }^{1}(\mathrm{ml} / \mathrm{g})$} & \multicolumn{3}{|c|}{ Sr sorption $\mathrm{K}_{\mathrm{d}}{ }^{1}(\mathrm{ml} / \mathrm{g})$} \\
\hline & untreated & $200^{\circ} \mathrm{C} / 30 \mathrm{MPa}$ & $300^{\circ} \mathrm{C} / 30 \mathrm{MPa}$ & untreated & $200^{\circ} \mathrm{C} /$ & ${ }^{\circ} \mathrm{C} / 30 \mathrm{MPa}$ \\
\hline Montmorillonite, WY & 410 & - & 180 & 170 & - & 250 \\
\hline Montmorillonite, TX & 310 & 350 & 160 & 310 & 270 & 170 \\
\hline Vermiculite, SC & 8900 & 7800 & 400 & 2000 & 440 & 130 \\
\hline Phillipsite, NV & 11700 & 4200 & 220 & 460 & 120 & 330 \\
\hline Mordenite, AZ & 8300 & 5100 & 6300 & 310 & 170 & 160 \\
\hline Mordenite, NV & 6400 & 4400 & 2600 & 170 & 160 & 130 \\
\hline clinoptilolite, ID & 3900 & 2100 & 1700 & 3000 & 1400 & 270 \\
\hline Clinoptilolite, CA & 5600 & 3600 & 2900 & 4700 & 1400 & 200 \\
\hline Erionite, $\mathrm{CA}$ & 9500 & 5200 & 520 & 490 & 270 & 220 \\
\hline Chabazite, AZ & 6600 & 3100 & 200 & 310 & 310 & 250 \\
\hline
\end{tabular}

$1_{\mathbb{K}_{d}}$ is a distribution coefficient and is defined as the ratio of the amount of cs sorbed per gram to the amount of unsorbed Cs remaining per milliliter of the solution. 
therefore they may have been mainly exchange-saturated with $\mathrm{K}^{+}$during the hydrothermal treatment with the Mg-rich brine at $200^{\circ} \mathrm{C}$. The $\mathrm{K}^{+}$ions in the hydrothermally treated zeolites compete much better with $\mathrm{Cs}^{+}$than the natural cations (mainly $\mathrm{Na}^{+}, \mathrm{Ca}^{2+}$, and some $\mathrm{K}^{+}$) present in the untreated zeolites (Ames, 1960, 1961, 1963) and therefore the selective Cs sorption may have decreased at this temperature.

At $300^{\circ} \mathrm{C}$, selective sorption of $\mathrm{Cs}^{+}$by all the hydrothermally altered minerals decreased (Table 4.3.5) because of the mineralogical alterations (Table 4.3.2). For example, formation of mica drastically reduced the Cs sorption by the vermiculite sample. Cs sorption $\mathrm{K}_{\mathrm{d}}$ decreased from 8900 in the untreated to 400 in the altered vericulite. Zeolites such as phillipsite, erionite and chabazite altered almost completely to montmorillonite in this Mg-rich brine and that is why the Cs sorption did not decrease as much as it did when these zeolites altered in NaCl brine to form albite. Albite has little cation exchange capacity while montmorillonite has high cation exchange capacity and the latter can sorb Cs. The case of phillipsite is really interesting because it altered completely to crystalline montmorillonite at $300^{\circ} \mathrm{C}$ and this montmorillonite has about the same specific $C s$ sorption capability as the untreated montmorillonites (Table 4.3.5).

The specific sorption of $\mathrm{Sr}$ by the untreated and hydrothermally altered minerals closely paralleled with the specific sorption of Cs at both the temperature of hydrothermal treatment and can be explained in the same fashion.

\subsubsection{Conc1usions}

Montmorillonites appear to be more stable than vermiculites or zeolites in either saturated $\mathrm{NaCl}$ brine or $\mathrm{Mg}-\mathrm{rich}$ brine under hydothermal conditions which may be expected in a salt repository for nuclear waste, based upon experiments up to 84 days duration. Vermiculites altered to interstratified vermiculite/mica or mica in brines containing $\mathrm{K}$. Zeolites altered to analcime and/or albite in the saturated $\mathrm{NaCl}$ brine but altered to montmorillonite in the $\mathrm{Mg}-\mathrm{rich}$ brine. Between montmorillonites and zeolites, the former should be preferred for a backfill in the waste package in a salt repository. However, these are at best short-term accelerated tests, and long-term stability of montmorillonite in saturated $\mathrm{NaCl}$ or $\mathrm{Mg-rich}$ brines expected in a salt repository need to be estab1ished, particularly in view of the thermodynamic considerations and natural analog occurrences previously discussed. 


\subsection{SALT CONSOLIDATION}

It is considered that a major portion of the repository room backfill of a bedded salt repository will consist of mined-out salt from the repository, consolidated to various degrees. However, there are major difficulties in achieving consolidation in a short time, to approach the theoretical density which would be necessary to prevent substantial liquid transport through the rooms and tunnels. This necessitates that the major sealing for at least hundreds of years will probably depend upon the contribution of structures consisting of the previous categories of seal materials.

Jenks (1979) used an approach of earlier workers to develop equations describing effects of temperature, temperature gradient, and irradiation damage on migration velocity. Brine migration experiments have been conducted with salts consolidated artiflcially from carefully sized particles to varying densities (Biggers and Dayton, 1979; White, 1981) and upon natural cores (Baes, 1981). Biggers and Dayton demonstrated that in salts having $>99 \%$ theoretical density that significant brine migration took place, primarily along grain boundaries. Therefore, the "permeability" to brine even in consolidated salts is not limited to that indicated by earlier theories and in some studies of migration of brine inclusions in single crystal halite (Olander et a1., 1980). It is expected to address the problem of salt consolidation and brine migration further in future studies. 


\section{STABILITY: OBSERVATIONS AND IMPLICATIONS}

\subsection{INTRODUCTION}

The determination of potential stability of seal materials in a repository envixonment can be approached in a number of ways, each having factors in its favor, as well as limitations. First are experiments in which specimens of seal material are subjected to various environmental treatments. These experiments are usually accelerated tests of extreme case potential reactions in which the sample is subjected to specific solutions, temperatures and pressure. often a shorter time exposure at elevated temperatures simulates a much longer time at lower temperatures. Actual ground water compositions may be less concentrated than the ones used, and the results may be more subtle. Nevertheless, the data are useful in postulating mechanisms of alteration, property enhancement or deterioration. A second source of information is thermodynamic data. Stability relations calculated from enthalpies and entropies of formation can give indications of ultimate long term reaction products in a relatively closed system. Experimental confirmation support the conclusions. Third are thermodynamic calculations of stable phases based on equilibrium with known groundwaters of lesser activities. Fourth are detailed kinetic studies and observations which give information on probable rates of change. The studies summarized in the following section have begun to address such different approaches.

\subsection{EFFECT OF VARIOUS ENVIRONMENTS ON PROPERTIES OF CEMENTITIOUS MIXTURE 80-081}

In order to evaluate the performance of potentially expansive cementitious mixtures in various environments, samples of a representative formulation (mixture 80-081) were cast as $50.8 \mathrm{~mm}$ cubes for unrestrained curing, as well as others cast inside $50.8-\mathrm{mm}$ diameter $\sim 40-\mathrm{mm}$ high stainless steel cylindrical molds (rings) and cured in the restrained condition.

The effects of four solutions and a high-humidity air environment upon the properties of the material were investigated. These environments were thought to represent extreme conditions which might be encountered in various geologic media. The curing conditions are summarized in Table 5.2.1.

Cubes and restrained cylinders were exposed to each of the five environments listed above, at $38^{\circ} \mathrm{C}$. Samples were examined after $24 \mathrm{~h}$, and periodically thereafter up to 180 days, to monitor the following: inception of macroscopic cracks, $\mathrm{pH}$ of curing solution; mineralogy via x-ray diffraction; and microstructure via 
Table 5.2.1. Curing enviroments of mixture 80-081.

brine
saturated $\mathrm{CaSO}_{4}$ solution
saturated $\mathrm{Ca}(\mathrm{OH})_{2}$ solution
humid air
deionized water

Table 5.2.2. Compressive strength $\pm \sigma$ of 50.8-mm cubes cured in various environments āt 180 days (MPa)

\begin{tabular}{lcc}
\hline curing conditions & compressive strength & $\pm \sigma(\mathrm{n})$ \\
\hline brine & 101.1 & $1.19(3) *$ \\
$\mathrm{CaSO}_{4}$ & 106.9 & $4.85(5)$ \\
$\mathrm{Ca}(\mathrm{OH})_{2}$ & 107.5 & $3.99(5)$ \\
humid air & 89.3 & $5.32(5)$ \\
deionized water & 109.9 & $3.46(5)$ \\
\hline
\end{tabular}

* Two samples were discarded due to the requirement of the $\pm 10 \%$ rule. These values were 84.5 and $84.7 \mathrm{MPa}$. 
SEM. Samples were photographed at $24 \mathrm{~h}$, at the onset of cracking and/or at 90 days of curing, and after 180 days.

The cubes cured in saturated $\mathrm{CaSO}_{4}$, saturated $\mathrm{Ca}(\mathrm{OH})_{2}$, and deionized water were observed to have surface cracks beginning at 7 to 14 days of curing. Cracking usually occurred parallel to cube edges, starting at an edge and progressing inward towards the center of the cube face, forming cross-shaped cracks. However, at 180 days, no cracking was observed in similar samples exposed to brine or to air. No cracking occurred in restrained-cylinder counterparts of all samples, although a volume increase was indicated by swelling of the upper (unrestrained) surface in some of the samples.

Cubes from all five curing conditions were still very strong when tested at $180 \mathrm{~d}$ even though some had cracks. Values of compressive strength for the cubes cured 180 days are delineated in Table 5.2.2. The samples which had shown surface cracking were also the samples with the highest values of compressive strength (saturated $\mathrm{CaSO}_{4}=106.9 \mathrm{MPa}$, saturated $\mathrm{Ca}(\mathrm{OH})_{2}=107.6 \mathrm{MPa}$, deionized water $=110.0 \mathrm{MPa}$ ). Compressive strength of one cube cured in brine was not significantly lower (101.22 MPa) but two samples had strengths of 84.5 and $85.7 \mathrm{MPa}$. The mean of the three specimens was $94.5 \mathrm{MPa} \pm 9.1$. The aircured sample had partially dehydrated during curing, and its lower compressive strength (89.4 $\mathrm{MPa})$ is consistent with this dehydration.

The restrained counterparts of the unrestrained cracked cube samples (CaSO, $\mathrm{Ca}(\mathrm{OH})_{2}$ and deionized water) were tested for permeability to water at v180 days. These exhibited no flow of water under the test conditions employed ( $p \sim 400$ psi, $t \sim 2$ to 3 days), indicating a permeability of less than $10^{-8}$ darcys. The aircured sample was allowed to dry, and due to shrinkage was no longer sealed in the restraining ring.

One cube from each curing condition was reserved for $x$-ray diffraction studies. A small piece was removed from one corner of each of these cubes at each test date, and was freeze-dried, intended to prevent further hydration. Slurries of powdered samples were mounted on glass slides and scanned at $2^{\circ} 2 \theta / \mathrm{min}$ with CuKo radiation. Phases identified by $x$-ray diffraction are listed in Table 5.2 .3 .

These data show the similarities of phase development between the cracked samples on the one hand and the uncracked samples on the other. Notable is the nearly identical phase development in all cracked samples regardless of the curing solution. Ettringite formation requires several ingredients: 1ime, 
Table 5.2.3. X-ray diffraction data.

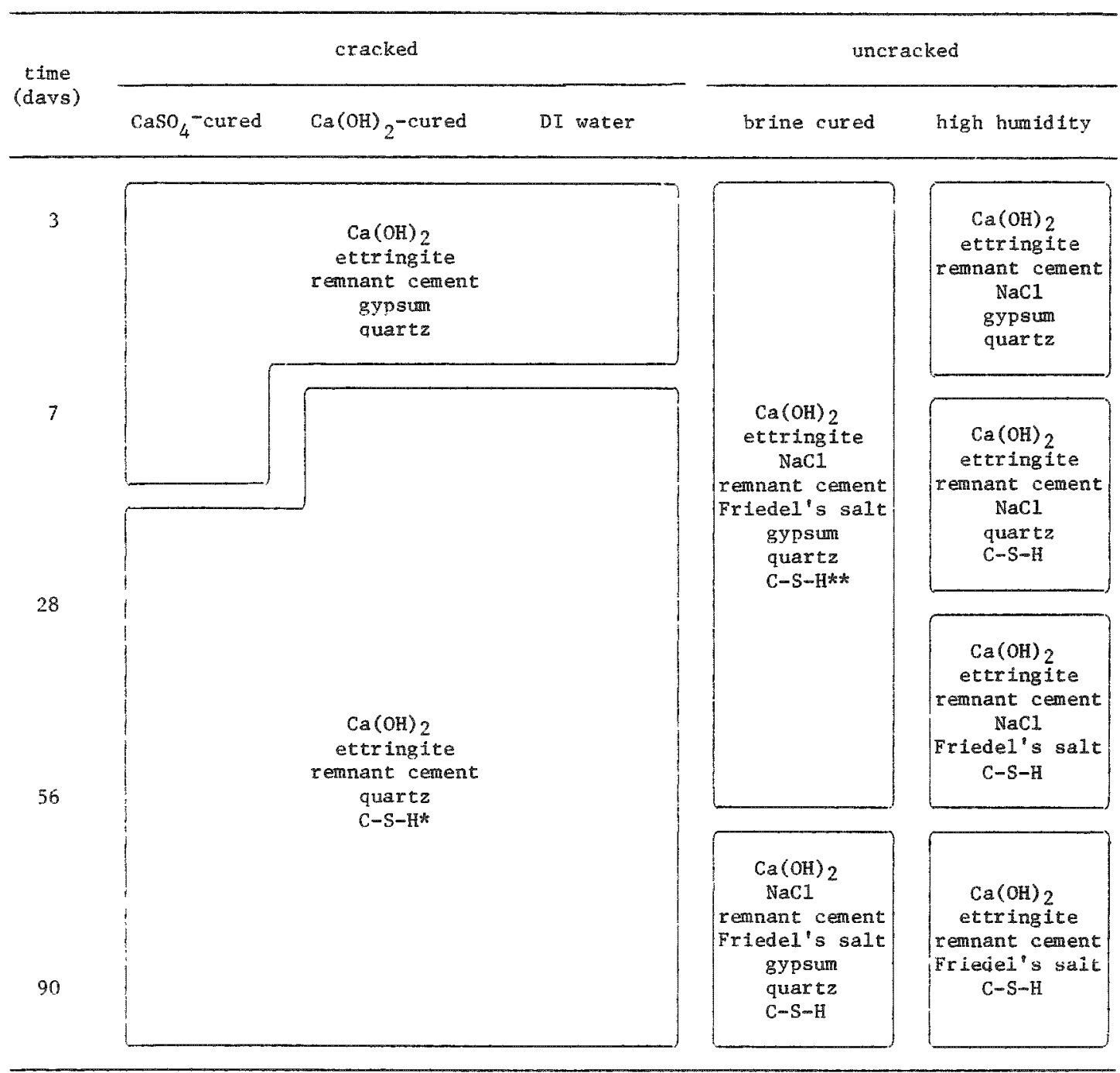

* Sma11 amounts of gypsum and $\mathrm{NaCl}$ were found at 28 days in $\mathrm{Ca}(\mathrm{OH})_{2}$ and $\mathrm{DI}$ water-cured samples, respectively.

**C-S-H was more prominent at 28 and 56 days. Assumed to be present at 3 and 7 days. 
alumina, sulfate and water. The degree of resulting expansion appears to be most related to the availability of water. However, if salt is added to the water or if the sample is allowed to cure in an environment where water is not abundant, ettringite formation is retarded or prevented; in one case the high chloride activity of the solution favors chloroaluminate formation, and in the other it lacks water. As a result, ettringite first coexists with the chloroaluminate phase (Friedel's salt) and eventually, in the case of the brine cure, completely converts to Friedel's salt by 90 days. In the air-cured sample, the conversion of early formed ettringite to Friedel's salt is slower, and both are seen to coexist at 90 days. Also of interest is the fact that gypsum is present in all of the solution-cured cements, which disappears after 3 days, except in the $\mathrm{CaSO}_{4}$-cured sample where it persists to 7 days. This gypsum apparently is converted to ettringite and thus is absent beyond 7 to 28 days. In the case of the brine-cured samples, gypsum persists throughout the curing history of the sample. Apparently chloroaluminate formation is favored over ettringite formation. In the air environment, gypsum is present at 3 days, but not beyond. It would seem that the air cure environment nearly mirrors the brine-free solution cure for 28 days, except that $\mathrm{NaCl}$ is present. At 56 days, chloroaluminate (Friedel's salt) begins to develop, and by 90 days free NaCI is no longer present.

\subsection{EFFECT OF TEMPERATURE/PRESSURE AND NaC1 ON ETTRINGITE STABILITX AND CHLOROALUMINATE (FRIEDEL'S SALT) FORMATION}

\subsubsection{Introduction}

No systematic study of ettringite stability under high temperature and pressure or in salt solutions has been reported previously; however, several studies revealed the stability of ettringite in dry and moist (autoclave) conditions.

From thermodynamic studies, Mchedlov-Petrossian (1965) calculated the free energies of formation of the tricalcium aluminate mono- and trisulfate hydrates, and indicated that above $70^{\circ} \mathrm{C}$ at 1 atm pressure monosulfate hydrate was more stable than trisulfate hydrate (ettringite).

In separate studies in this 1aboratory, experiments therefore were carried out to determine the stability of ettringite under different conditions. A stationary cold-seal type hydrothermal furnace was used to examine the stability 
of ettringite in both deionized water and $\mathrm{NaCl}$ solution, under high temperatures and pressures. The solid phases of reaction products were analyzed by $x-x a y$ diffraction and SEM. The starting material was pure ettringite prepared from solution in the laboratory. Two kinds of liquids were used: freshly decarbonated deionized water and a $20 \% \mathrm{NaCl}$ solution. The solid phase, suspended in the 1iquid phase, was put into a Teflon tube, one end of which had been sealed. The other end was then sealed, and the capsule was placed in the autoclave and pressurized. Temperature was raised, keeping the pressure constant, and the sample was cured for one week after temperature and pressure became constant. After curing, the Teflon capsule was taken out of the pressure tube. The contents were filtered and the solid phase was dried in a desiccator.

\subsubsection{Results and Discussion}

Stability of Ettringite in Deionized Water. Figure 5.3.1 is the phase diagram for the stability of ettringite in deionized water. Closed circles show ettringite which was not decomposed, and open circles indicate decomposition to other phases. In deionized water, the decomposition temperature was between $145^{\circ}$ to $150^{\circ} \mathrm{C}$ at pressures above 400 psi. This was lowered slightly at lower pressure and reached $130^{\circ} \mathrm{C}$ at $100 \mathrm{psi}$.

Monosulfate hydrate was a major phase formed by decomposition of ettringite, and hemihydrate $\left(2 \mathrm{CaSO}_{4} \cdot \mathrm{H}_{2} \mathrm{O}\right)$ also was recognized by $\mathrm{x}$-ray diffraction. At higher temperatures, that is $150^{\circ} \mathrm{C}, 600 \mathrm{psi}$ and $150^{\circ} \mathrm{C}, 400 \mathrm{psi}$, a small amount of anhydrite was detected.

Scanning electron micrographs of the solid phase showed characteristic ettringite rods at $105^{\circ} \mathrm{C}$, while at $150^{\circ} \mathrm{C}, 600 \mathrm{psi}$, pseudo-hexagonal outlines of monosulfate hydrate plates with many hexagonal holes were observed.

Stability of Ettringite in $20 \% \mathrm{NaCl}$ Solution. In a $20 \% \mathrm{NaCl}$ solution, ettringite was decomposed at a lower temperature, as shown in Figure 5.3.2. Though the decomposition temperature had a certain width, throughout the pressure range examined, ettringite was decomposed between $95^{\circ}$ to $105^{\circ} \mathrm{C}$, which was 1 ower than that in deionized water by about $40^{\circ} \mathrm{C}$. Decomposition product phases were mainly gypsum and Friedel's salt, and almost no monosulfate was recognized by $x$-ray diffraction. Scanning electron micrographs of decomposition products show large rod-1ike gypsum crystals and very fine irregular particies which are probably Friedel's salt: 


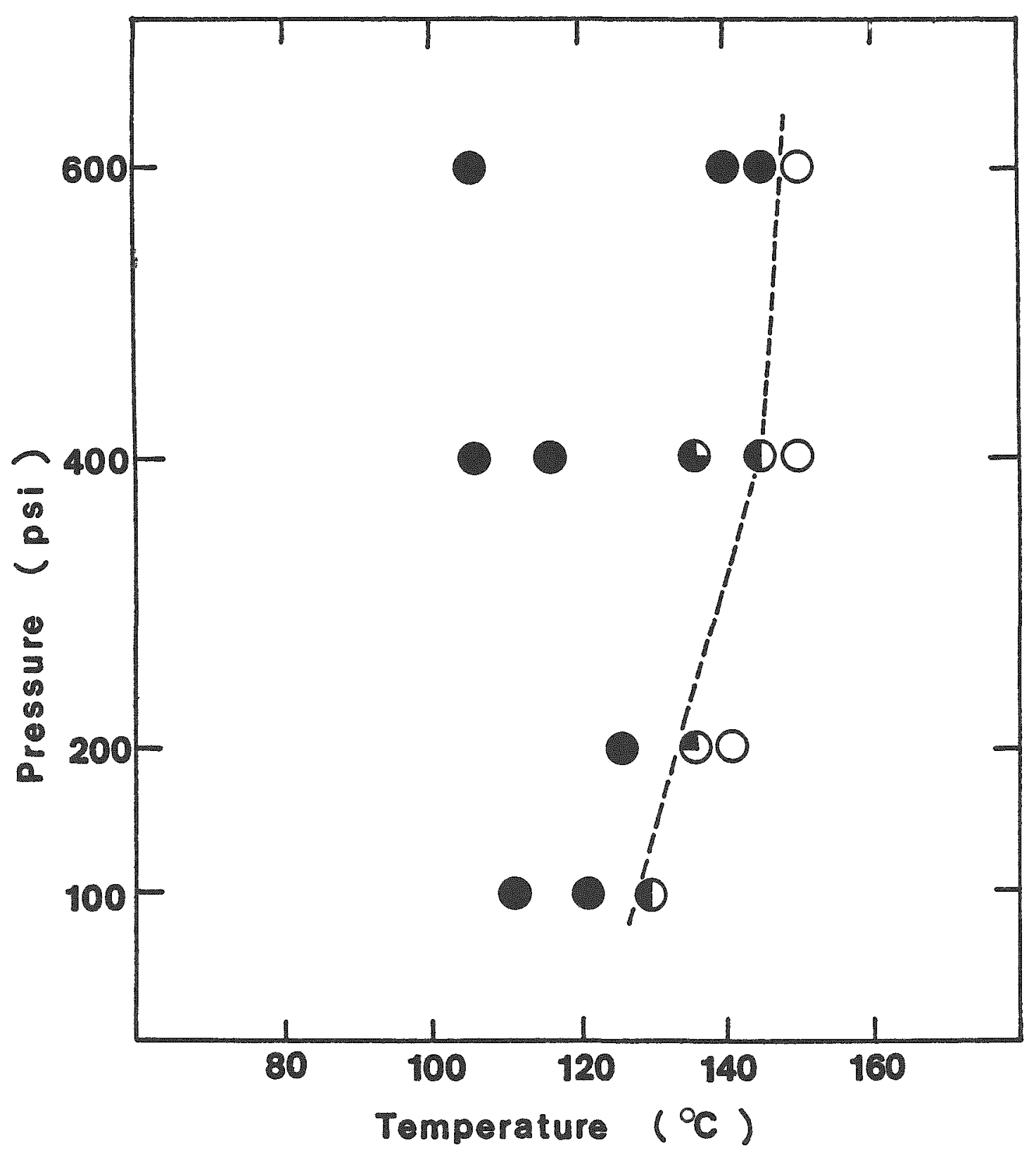

Figure 5.3.1. Stability of ettringite under high temperature and high pressure in delonized water. Closed circles: ettringite is stable. Open circles: ettringite is decomposed. 


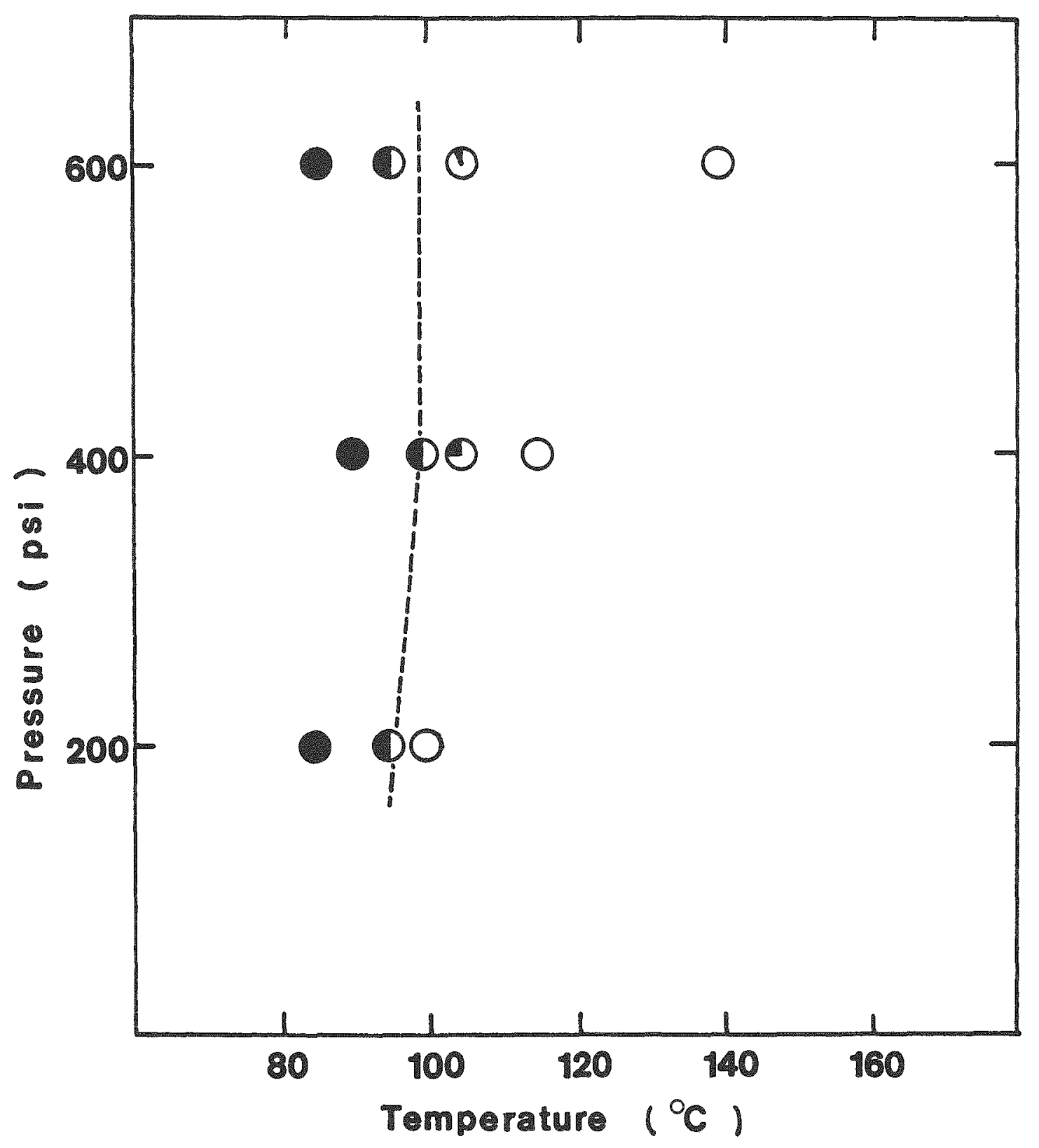

Figure 5.3.2. Stability of ettringite under high temperature and high pressure in $20 \% \mathrm{NaCl}$ solution. Closed circles: ettringite is stable. Open circles: ettringite is decomposed. 
Detailed study is still necessary to determine the process of the decomposition of ettringite in $\mathrm{NaCl}$ solution, but apparently at temperatures above about $100^{\circ} \mathrm{C}$ at elevated pressures the combination Friedel's salt $\left(\mathrm{C}_{3} \mathrm{~A} \cdot \mathrm{CaCl}_{2} \cdot \mathrm{H}_{10}\right)$ + calcium sulfate $+\mathrm{NaOH}$ is more stable than the combination ettringite $+\mathrm{NaCl}$.

\subsubsection{Conclusions}

1) Ettringite was decomposed at $130^{\circ}$ to $150^{\circ} \mathrm{C}$ in the range $100 \mathrm{psi}$ to 600 psi in deionized water, yielding monosulfate hydrate as the main decomposition product. Hemihydrate and anhydrite were also formed. The morphology of the monosulfate hydrate thus formed was different from that in cement paste, that is, hexagonal holes and frace crystal growth were observed in the crystalline mass.

2) In a $20 \% \mathrm{NaCl}$ solution, ettringite was decomposed at a temperature about $40^{\circ} \mathrm{C}$ lower than that required for decomposition in deionized water. Gypsum and $\mathrm{C}_{3} \mathrm{~A} \cdot \mathrm{CaCl}_{2} \cdot \mathrm{H}_{10}$ were the main products formed.

\subsection{INTERFACE REACTIONS}

\section{4 .1 Introduction}

The contact between a cementitious plugging material and host rock has been postulated as being a critical area for the success of a seal. Inadequate performance is believed to occur most commonly in the annular region between the plug and the face of the borehole or shaft, or else in a disturbed zone in the rock. At least two mechanisms are apparent for developing a cementitious seal. one is mechanical and the other is chemical. The first is established once the matrix hardens. From that point, the grout or concrete must necessarily remain firmly in place against the host rock to prevent annular cracking. This mechanical feature can be enhanced by using expansive cement formulations, such as those already discussed. It is important for the plug to maintain contact with the wall rock from the initial set, at least until chemical bonding is estab1ished. (The exceptions occur in certain seal designs, where expansion of a swelling clay component, against concrete and rock, will provide the back-up seal).

Current research on pozzolanicity in concrete materials indicates that the reaction between a silicate rock and portland cement-based materials will most likely be very slow at room temperature, but the bond may be strong in the long term. The bonding between cement and rocks such as salt, dolostone and anhydrite 
is believed to depend more upon reactions between the calcium aluminate hydratesubstituted AFt and AFm phases such as ettringite and Friedel's salt for its development. Since the quantity of aluminates in the cement is 1 imited $(<20$ wt \%) this controls the extent of such phase formation and consequent bonding. However, the substituted aluminate hydrates, particularly ettringite, are expansive, and especially in the interfacial region may be high in $\mathrm{Cl}^{-}, \mathrm{SO}_{4}=$ and/or $\mathrm{CO}_{3}$, these phases may swell with the addition of water, and seal any annular regions which are weak or would provide preferential pathways for water transport.

\section{4 .2 Interfacial Studies}

In order to test these concepts, various interfacial studies have been carried out. One set was concerned with development of the chemical interface. Various mixtures were cast on silicate substrates, cured, and subequently pulled apart, testing for strength and evidence of interfacial reaction by SEM examination. Some of these data have appeared elsewhere (Langton et a1., 1980a; Roy et al., 1978). The studies confirmed the occurrence of a $\mathrm{Ca}(\mathrm{OH}) 2^{-r i c h}$ layer adjacent to the silicate substrate. Tabor (1981) has postulated that a bond involving $\mathrm{Ca}(\mathrm{OH})_{2}$ is not as strong as that involving $\mathrm{C}-\mathrm{S}-\mathrm{H}$. ConsequentIy, bonding should not be as strong as its potential until after the silicates in the rock react and combine with calcium hydroxide from the cement to form additional C-S-H. At elevated temperatures this happens relatively rapidly. Work by Grutzeck et a1. (1981b) has shown that once established, massive $\mathrm{Ca}(\mathrm{OH})_{2}$ provides an effective barrier to diffusion of water, and fly ash glass spheres engulfed by $\mathrm{Ca}(\mathrm{OH})_{2}$ are retarded in their reaction. The existence of such calcium hydroxide layer surfaces on a plug surface in a repository shaft might prevent adequate bonding from taking place later. Experiments with 1 imedepleted cements are attempting to reduce such barriers to rapid build-up of bond strength between cement and wall rock.

In other studies, the evaluation of bond strength (in shear) and permeability of composite cylindrical samples of host rock filled with cementitious formulations has been made. Procedures for these tests are given in Langton etal. (1980b),

One study cast small simulated borehole plugs in cores of Castile formation anhydrite. The mixtures used were BCT-1FF (79-091) and PSU salt-free (79-080) discussed in section 3.1. Both permeability and bond strength measurements were made. 
Permeabilities of these simulated borehole samples determined parallel to the cylinder axis, were commonly about $10^{-6}-10^{-7} \mathrm{um}^{2}$ (darcys) for samples cured 7 to 28 days at $35^{\circ} \mathrm{C}$ in a complex $\mathrm{Mg}$ brine (WIPP-A). Bond strength was measured by pushing out the plug. Although there are some limitations of the measurement method, the values were reasonably consistent, increasing with curing time to 28 days. Values at 7,14 and 28 days were approximately 4.9, 7.1, and 14.2 MPa for the 79-091 mortar in anhydrite. Additional data are available in Gulick et al. (1980a).

Similar bond strength and permeability tests for mixtures 79-040 and 79-050 at $60^{\circ}$ and $90^{\circ} \mathrm{C}$ were completed. Formulations for these mixtures are given in section 3.3. These mixtures were cast in quartzite and limestone cores, respectively. Again permeabilities were on the order of $10^{-6}$ to $10^{-7}$ darcys $\left(\mu \mathrm{m}^{2}\right)$ through 28 days for mixqure $79-040$ and $10^{-6}$ to $10^{-7}$ darcys ( $\mu \mathrm{m}^{2}$ ) for mixtures 79-050 through 14 days. However, at 28 days high flow rates were observed for mixture 79-050 cast in 1imestone. Bond strengths in shear for both mixtures are given in Table 5.4.1. The mixtures are relatively similar but their bond strengths and permeabilities are different, especially at 28 days.

What is apparent from such studies is the effect of the degree of expansion of the mixture and the composition of the host rock upon the final properties of the composite material. The BCT-IF and PSU salt-free formulations had low w/c ratios, were expansive, and moderately compatible with their host rock, and thus have comparatively low permeabilities and high bond strengths. In comparison, the formulations $79-040$ and $79-050$ had higher w/c ratios (the former 0.69 , and the latter 1.28 ) and were not designed to be expansive. Consequently, the early stage properties are not as good, since bonding involves both physical and chemical components.

The sample in the quartzite cylinder (simulating sandstone or silicate strata) showed relatively good bonding and adequate mechanical properties. The reasons for the inferior properties in the limestone cylinder are not fully explained. Perhaps it is related to the very high $\mathrm{w} / \mathrm{c}$ ratio.

Additional work in these areas is expected to give significant evidence in evaluating potential long term durability of key formulations. Physical expansion obviously provides a seal, and suitable chemical interaction, in the absence of physical expansion may also provide a seal. 
Table 5.4.1. Shear bond strength of mixtures cast in rock cylinders (MPa).

\begin{tabular}{|c|c|c|c|}
\hline \multirow{2}{*}{ formulation } & \multirow{2}{*}{$\begin{array}{c}\text { time } \\
\text { (days) }\end{array}$} & \multicolumn{2}{|c|}{ curing temperature, } \\
\hline & & $60^{\circ}$ & $90^{\circ}$ \\
\hline $\begin{array}{l}79-040 \\
\text { in quartzite }\end{array}$ & 14 & 6.27 & 5.32 \\
\hline cores & 28 & 9.97 & 3.99 \\
\hline $\begin{array}{l}79-050 \\
\text { in Iimestone }\end{array}$ & 14 & 5.25 & 7.56 \\
\hline cores & 28 & 1.14 & 1.50 \\
\hline
\end{tabular}




\subsection{DIFFUSION STUDIES; KINETICS}

Transport phenomena in a hardened cement paste are very important to its durability, potentially affecting phase and properties changes. Factors affecting permeability of water through hardened cement pastes have been discussed elsewhere (Goto and Roy, 1981; Parker and Roy, 1982).

The ionic diffusion in a given material is influenced by the interaction of many variables, including the chemical composition, porosity and pore structure of the hardened cement paste; as well as temperature, pressure and electrical potential.

Diffusion of $\mathrm{Na}^{+}$and $\mathrm{Cl}^{-}$Lons through thin hardened cement paste sections was determined as a function of water/cement ratio, curing time, curing temperature, and diffusion temperature (Goto and Roy, 1981). Diffusivities of $\mathrm{Na}^{+}$ ions were found to be smaller than for $\mathrm{Cl}^{-}$ions in the temperature range measured up to $60^{\circ} \mathrm{C}$. Activation energies for diffusion were calculated, and contrasts were made with diffusion through a low porosity quartzite rock having minimal surface interaction with the diffusing species.

Diffusion coefficients for $\mathrm{Na}^{+}$in the range of $10^{-7}$ to $10^{-9} \mathrm{~cm}^{2} \mathrm{sec}^{-1}$ have been measured in cement pastes in work in the laboratory (see Figure 5.5.1). Comparisons with the diffusion of divalent ions are of interest. Spinks, et al. (1952) determined the diffusion coefficient of $\mathrm{Ca}^{2+}$ in mortars to be $2.8 \times 10^{-10}$ $\mathrm{cm}^{2} \mathrm{sec}^{-1}$, while Forrester and Lawrence (1961) determined extremely low selfdiffusion coefficients in calcium silicate hydrates, which ranged from 1.08 to $60.7 \times 10^{-23} \mathrm{~cm}^{2} \mathrm{sec}^{-1}$, following release of more rapidly exchangeable species. Recent research has demonstrated that very fine pore structures exist in certain hydrated cementitious materials of low free calcium hydroxide content (Parker and Roy, 1982). It will be important to determine if both fine pore structure and low calcium hydroxide contents can be correlated with lower diffusion rates.

\subsection{PHASES STABLE WITH RESPECT TO LOS MEDANOS WATERS}

The purpose of the thermodynamic calculations was to compare products of activities calculated from free energies with those calculated from grounwater compositions. If they match, the species is considered to be stable. The water compositions can thus be shown to be in equilibrium with their geologic formation, or to be undersaturated with respect to their formation or to contain ions from another source. By the same methods the stability of the seal material phases with respect to the groundwaters may be determined. 


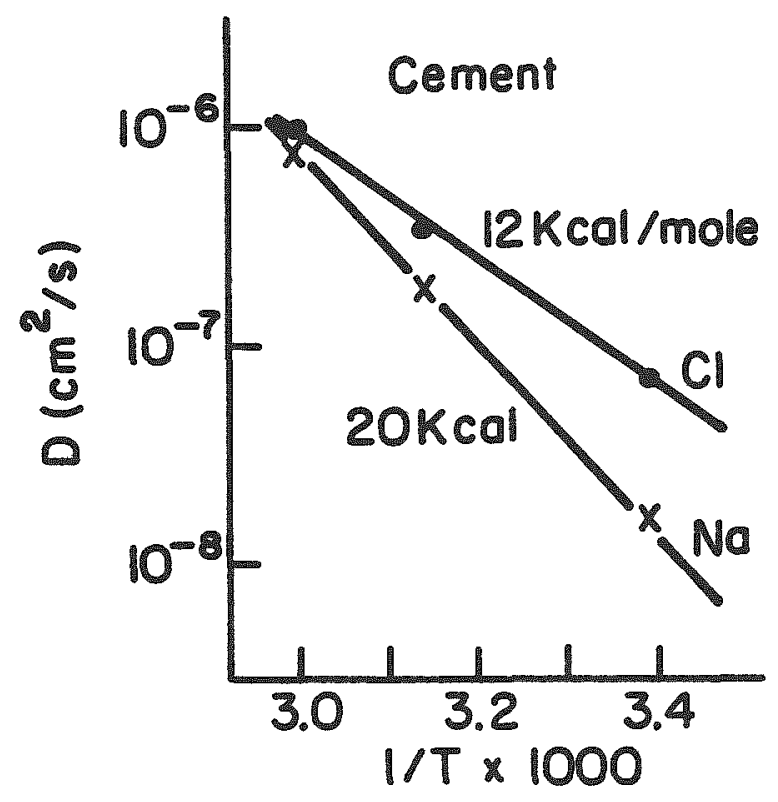

$\begin{aligned} \text { Figure 5.5.1. } & \text { Diffusion coefficients for } \mathrm{Na}^{+} \text {and } \\ & \mathrm{Cl} \text { in cement paste. Activation } \\ & \text { energies for diffusion are given. }\end{aligned}$ 
As a first approximation activity coefficients were assumed to be equal to one; then activities from the mean salt method (Garrels and Christ, 1965) were included. The differences on the log activity scale were small except for the most concentrated brines in the Salado and Castile. No mean salt activities were found for $\mathrm{Mg}$, so the activity coefficient of $\mathrm{Mg}$ continued to be assumed equal to one. Activities calculated from Debye-Hiickel cannot be used beyond an ionic strength of 0.1 ; the ionic strength of these brines varies from $0.4-10$.

The calculated activity ratios were then compared with activity diagrams. For reactions between phases for which activity diagrams were not available, relative stability was determined by calculating from known free energies of formation, the free energy of reaction, $\Delta G_{r}^{\circ}$ :

$$
\Delta G_{I}^{\circ}=-2.303 R T \log K_{r}
$$

where $\quad R=$ gas constant

$\mathrm{T}=$ absolute temperature

$K_{r}=$ activity product for reaction.

For instance for solution or precipitation of anhydrite:

$$
\begin{aligned}
& \mathrm{CaSO}_{4}=\mathrm{Ca}+2 \mathrm{SO}_{4}^{-2} \\
& \log \mathrm{K}_{r}=\log \left(\mathrm{a}_{\mathrm{Ca}}+2\right)\left(\mathrm{a}_{\mathrm{SO}_{4}^{-2}}\right)
\end{aligned}
$$

At $25^{\circ} \mathrm{C}$,

$$
\begin{aligned}
& -2.303 \mathrm{RT}=-1.364 \\
& \Delta \mathrm{G}_{\mathrm{r}}^{\circ}=-1.364 \log \mathrm{K}_{\mathrm{r}}
\end{aligned}
$$

If the brine in question is stable with respect to the species of interest, the $\log \mathrm{K}_{r}$ calculated from brine compositions will be the same as the $\log \mathrm{K}_{r}$ from free energies, within the errors of the method. The latter may be considerable; an error in free energy of one kcal/mol makes an error of 0.7 in $\log \mathrm{K}_{\mathrm{r}}$, or a factor of five in solution composition. Errors in activity coefficient may cause up to an error of 2 in $\log \mathrm{K}_{\mathrm{r}^{\circ}}$

Water analyses were from Powers et al. (1978). $\mathrm{Na}^{+}, \mathrm{K}^{+}, \mathrm{Mg}^{+2}, \mathrm{Ca}^{+2}, \mathrm{HCO}_{3^{2}}^{-} \mathrm{SO}_{4}^{-2}$ were given, $A 1$ is missing and $S i$ is only known as a range (0-2 ppm). There were two samples each from the Magenta and Culebra dolomites, four from the Salado, two from the Castile and one from the Bell Canyon. A third analysis 
from the Castile was not used because it was wildly aberrant $(\mathrm{pH}=1.6)$. In the other samples activity ratios were consistent within each formation for each reaction considered.

Activity ratios for $\mathrm{Na} / \mathrm{H}, \mathrm{K} / \mathrm{H}, \mathrm{Ca} / \mathrm{H}$, and $\mathrm{Mg} / \mathrm{H}$ are given in Table 5.5.1. Because silica concentration is only known as 0-2 ppm (maximum log silica mola1ity of -4.5$)$, the activity ratios of the ions in water are not plotted on the diagrams, but are presented in Table 5.6.1.

The difference between the activity ratios for calcium and magnesium in the high-ionic-strength Salado waters, and in the other formation waters, may be an artifact of the error in activity coefficients. Particularly in the case of magnesium an error of two units in $\log \mathrm{K}$ is to be expected. The stabilities of some mineral phases are shown in Table 5.6.2. Inaccuracies in activity coefficients mean that the method will not distinguish between anhydrite (1og $K_{r}=-4.1$ ) and gypsum $\left(\log K_{r}=-4.6\right)$ in the most concentrated brines. In the case of the magnesium minerals, the activities found from groundwater concentrations are all near both the kaolinite-gibbsite-chlorite join and the chlorite$\mathrm{Mg-smectite-kaolinite} \mathrm{join,} \mathrm{so} \mathrm{that} \mathrm{either} \mathrm{or} \mathrm{both} \mathrm{chlorite} \mathrm{and} \mathrm{Mg}$-smectite are predicted to be stable within the error of the method.

These results from the groundwater geochemistry support the interpretation in section 4.1 of the clay mineralogy of the Salado that the corrensite (chlorite-smectite mixed layer) found there is diagenetic in origin: the present-day brines are sufficiently high in magnesium to replace the potassiumbearing illite by magnesium-bearing chlorite. In the Dewey Lake red beds high above the salt formations, the clays are illite-smectites and presumably detrital.

The phases which are not stable throw light on the unusual mineralogy of salt formations. The calcium does not enter the clays or zeolites as in many silicate rocks, but is primarily concentrated in sulfates and carbonates. The magnesium on the other hand forms the clays and chlorite as well. Aluminum is present in very small amounts and occurs as illite and chlorite but not in smectites. Sodium is principally in halite, and potassium in polyhalite.

Table 5.6 .3 shows the relative stability of Friedel's salt and ettringite in brines. Sarkar et al. (1980) discussed these compounds in an earlier report in this study. Friedel's salt is stable in these brines. Ettringite is stable with respect to $\mathrm{C}_{3} \mathrm{~A}$ in a typical brine, but hydrogannet appears to be stable with respect to ettringite at these same water compositions.

What needs to be determined next is the relative stability of Friedel's salt, ettringite, and any intermediates. 
Table 5.6.1. Molalities and activity ratios at $25^{\circ} \mathrm{C}$ in Los Medanos waters, calculated from compositions given by Powers et al. (1978). Activity coefficients are from the mean salt method except for magnesium for which activity coefficient is assumed $=1$.

\begin{tabular}{|c|c|c|c|c|c|c|c|c|c|c|}
\hline $\begin{array}{c}\text { Sample } \\
\text { Number } \\
\text { acc. Powers }\end{array}$ & formation & $\mathrm{pH}$ & $\begin{array}{c}\text { Na } \\
\text { molality }\end{array}$ & $\log \frac{\mathrm{a}_{\mathrm{Na}^{+}}}{\mathrm{a}_{\mathrm{H}}{ }^{+}}$ & $\frac{\mathbb{K}}{\text { molality }}$ & $\log \frac{a_{\mathrm{Na}^{+}}}{a_{\mathrm{K}}{ }^{+}}$ & $\begin{array}{c}\mathrm{Ca} \\
\text { molality }\end{array}$ & 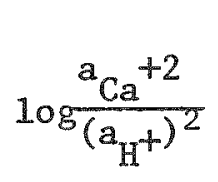 & $\begin{array}{c}\mathrm{Mg} \\
\text { molality }\end{array}$ & $\log \frac{{ }^{a} \mathrm{Ca}^{+2}}{\left(a_{H}+\right)^{2}}$ \\
\hline $\begin{array}{l}22 \\
24\end{array}$ & $\begin{array}{l}\text { Magenta } \\
\text { Magenta }\end{array}$ & $\begin{array}{l}7.4 \\
7.4\end{array}$ & $\begin{array}{l}0.248 \\
0.183\end{array}$ & $\begin{array}{l}6.5 \\
6.5\end{array}$ & $\begin{array}{l}0.00179 \\
0.00256\end{array}$ & $\begin{array}{l}4.5 \\
4.6\end{array}$ & $\begin{array}{l}0.0222 \\
0.0180\end{array}$ & $\begin{array}{l}12.6 \\
12.5\end{array}$ & $\begin{array}{l}0.0111 \\
0.0078\end{array}$ & $\begin{array}{l}12.8 \\
12.7\end{array}$ \\
\hline $\begin{array}{l}23 \\
25\end{array}$ & $\begin{array}{l}\text { Culebra } \\
\text { Culebra }\end{array}$ & $\begin{array}{l}7.6 \\
7.4\end{array}$ & $\begin{array}{l}0.409 \\
0.826\end{array}$ & $\begin{array}{l}7.1 \\
7.2\end{array}$ & $\begin{array}{l}0.00485 \\
0.0155\end{array}$ & $\begin{array}{l}5.1 \\
5.3\end{array}$ & $\begin{array}{l}0.0195 \\
0.0374\end{array}$ & $\begin{array}{l}12.9 \\
12.8\end{array}$ & $\begin{array}{l}0.0115 \\
0.0296\end{array}$ & $\begin{array}{l}13.3 \\
13.3\end{array}$ \\
\hline $\begin{array}{r}3 \\
4 \\
5 \\
16\end{array}$ & $\begin{array}{l}\text { Salado } \\
\text { Salado } \\
\text { Salado } \\
\text { Salado }\end{array}$ & $\begin{array}{l}5.5 \\
5.4 \\
5.5 \\
5.8\end{array}$ & $\begin{array}{l}1.196 \\
1.931 \\
2.01 \\
2.13\end{array}$ & $\begin{array}{l}5.9 \\
7.0 \\
6.5 \\
6.6\end{array}$ & $\begin{array}{l}0.0767 \\
0.774 \\
0.774 \\
1.34\end{array}$ & $\begin{array}{l}4.1 \\
5.0 \\
5.1 \\
5.8\end{array}$ & $\begin{array}{l}0.0160 \\
0.0125 \\
0.0130 \\
0.0314\end{array}$ & $\begin{array}{r}9.7 \\
9.4 \\
9.6 \\
10.6\end{array}$ & $\begin{array}{l}2.28 \\
2.58 \\
2.55 \\
1.58\end{array}$ & $\begin{array}{l}11.4 \\
11.0 \\
11.2 \\
12.0\end{array}$ \\
\hline $\begin{array}{l}14 \\
15\end{array}$ & $\begin{array}{l}\text { Castile } \\
\text { Castile }\end{array}$ & $\begin{array}{l}7.3 \\
7.7\end{array}$ & $\begin{array}{l}4.87 \\
5.42\end{array}$ & $\begin{array}{l}8.1 \\
8.6\end{array}$ & 0.13 & 6.2 & $\begin{array}{l}0.00324 \\
0.0137\end{array}$ & $\begin{array}{l}12.1 \\
13.5\end{array}$ & $\begin{array}{l}0.0144 \\
0.0765\end{array}$ & $\begin{array}{l}12.8 \\
14.3\end{array}$ \\
\hline 9 & $\begin{array}{l}\text { Be11 } \\
\text { Canyon }\end{array}$ & 7.1 & 3.34 & 7.7 & 0.0435 & 5.6 & 0.689 & 13.8 & 0.250 & 13.6 \\
\hline
\end{tabular}


Table 5.6.2. Stability of mineral phases in Los Medanos waters at $25^{\circ} \mathrm{C}$. A phase is considered stable in the water under consideration if its activity produce calculated from groundwater composition is equal to that calculated from free energies within the calculated error.

\begin{tabular}{|c|c|c|c|c|c|}
\hline \multirow[b]{2}{*}{ Formation } & \multicolumn{5}{|c|}{ Mineral } \\
\hline & Halite & $\begin{array}{c}\text { gypsum } \\
\text { or } \\
\text { anhydrite }\end{array}$ & dolomite & clays & feldspars \\
\hline Magenta & no & gypsum & yes & $\begin{array}{l}\text { Mg-smectite } \\
\text { chlorite } \\
\text { kaolinite }\end{array}$ & $\begin{array}{l}\mathrm{Na}- \\
\text { feldspar }\end{array}$ \\
\hline Culebra & no & gypsum & yes & $\begin{array}{l}\text { Mg-smectite } \\
\text { chlorite } \\
\text { kaolinite }\end{array}$ & $\begin{array}{l}\mathrm{Na}- \\
\text { feldspar }\end{array}$ \\
\hline Salado & yes & $\begin{array}{l}\text { either } \\
\text { gypsum } \\
\text { or anhydrite }\end{array}$ & yes & $\begin{array}{l}\text { kaolinite } \\
\text { probably } \\
\text { Mg-smectite } \\
\text { and chlorite }\end{array}$ & no \\
\hline Castile & no & $\begin{array}{l}\text { either } \\
\text { gypsum } \\
\text { or anhydrite }\end{array}$ & no & $\begin{array}{l}\text { chlorite } \\
\text { illite } \\
\text { Mg-smectite } \\
\text { kaolinite }\end{array}$ & $\begin{array}{l}\mathrm{Na}- \\
\text { feldspar }\end{array}$ \\
\hline $\begin{array}{l}\text { Be11 } \\
\text { Canyon }\end{array}$ & no & gypsum* & no & $\begin{array}{l}\text { chlorite } \\
\text { Mg-smectite } \\
\text { kaolinite }\end{array}$ & $\begin{array}{l}\mathrm{Na}- \\
\text { feldspar }\end{array}$ \\
\hline
\end{tabular}

*Bell Canyon waters according to these $25^{\circ} \mathrm{C}$ calculations are only slightly undersaturated with respect to anhydrite; in fact temperatures in Bell Canyon formation are much greater than $25^{\circ} \mathrm{C}$, therefore anhydrite is probably stable rather than gypsum. 
Table 5.6.3. Stability of cement phases in brines; brine composition from Powers et al. (1978).

\begin{tabular}{ll} 
"typical" brine composition & brine WIPP-A \\
\hline $\mathrm{Ca}^{+2}=0.003 \mathrm{~m}$ & $\mathrm{Ca}^{+2}=0.0126$ \\
$\mathrm{CO}_{3}^{-2}=0.011 \mathrm{~m}$ & $\mathrm{Cl}^{-}=4.55$ \\
$\mathrm{Cl}^{-}=4.624 \mathrm{~m}$ & Friedel's salt stable \\
$\begin{array}{l}\text { Friedel's salt stable with } \\
\text { respect to } \mathrm{C}_{3} \mathrm{~A}\end{array}$ \\
$\begin{array}{l}\text { Ettringite stable w/r } \mathrm{C}_{3} \mathrm{~A} \\
\text { Hydrogarnet stable w/x } \\
\text { ettringite }\end{array}$
\end{tabular}


6 CONCLUSIONS AND RECOMMENDATIONS

The experimental program has demonstrated that seal materials can be designed that are suitable for rock types characteristic of a bedded salt repository environment. Cementitious materials can be tailored to take advantage of the chemistry of a particular strata, be it salt, anhydrite, dolomite or silicate. Emphasis now lies on long-term evaluation of stability of materials specific to the various horizons.

The studies carried out have led to the following conclusions:

1. It is possible to formulate cementitious seal materials which are essentially impermeable, are usually strong and which appear suitable for sealing various geologic formations existing in a bedded salt repository area.

2. Such seal materials can be designed with specific properties, to perform in a desired fashion which will take advantage of the chemistry of the host rocks.

3. Since the integrity of the seal is dependent upon the nature of the interfacial zone, combinations of physical, chemical and mechanical effects must be optimized. The chemical potential or chemical gradients should be minimized, the volume stability maintained, thermal properties matched insofar as feasible, and the bonding should be optimized as much as possible.

4. Intrinsic stability of cementitious materials may be generated by partial replacement of cement with pozzolanic materials such as silica fume and fly ash, combined with use of high-range water reducers to generate low porosity and permeability. Such materials generally are expected to have greater longevity than non-substituted counterparts.

5. Formulations which generate slight expansive stresses tend to promote initially stronger seals, since the seal is potentially both chemical and mechanical in nature. Under the correct circumstances, the expansive mechanism can be based upon AFt (ettringite) or even possibly AFn (Friedel's salt) phase formation. Other methods for generating slightly expansion, some conventional, some to be developed, may be needed for different chemical and physical environments.

6. Free $\mathrm{Ca}(\mathrm{OH})_{2}$ should be reduced with pozzolans, and additional strength will usually be realized from the formation of additional amounts of the major cementing phase, $\mathrm{C}-\mathrm{S}-\mathrm{H}$. 
7. Magnesium-containing clay mineral varieties appear to be most nearly in equilibrium with the various brine environments. The selection of specific clay and zeolite-containing seal materials for best potential performance in different horizons will require additional research. Such materials will possess important properties complementary to those of cementitious materials.

8. Potential seal materials which are hybrid between cementitious materials and clays show promise, having intermediate type properties, and merit further study.

The following recommendations are in order when attempting to assure the durability of a seal in a silicate host rock: Development of a seal materialhost rock bond which involves $\mathrm{C}-\mathrm{S}-\mathrm{H}$ rather than simply calcium hydroxide is important. This is 1ikely to be achieved by using low calcium aluminate cements and reducing free lime content by reaction with suitable pozzolans. Inder certain circumstances Class $\mathrm{C}$ fly ashes and/or granulated blast furnace slag will be desirable constituents.

Aluminate-derived hydrate phases appear to be more compatible with the host rock, when considering carbonate, sulfate or salt rocks, since such hydrated phases can accept the appropriate carbonate, sulfate or chloride ions into their structures to a larger extent than can the silicate phase, $\mathrm{C}-\mathrm{S}-\mathrm{H}$. Silica fume should still be used to reduce free lime.

In all cases, once in place and hardened, the cementitious seal material should maintain its volumetric stability while in contact with the rock. Shrinkage should be avoided as a chemical bond develops. Most conventional portland cements in the course of hydration undergo slight shrinkage. This is minimized by keeping low water contents, and using a large proportion of aggregate. Formation of AFt or AFm phases at an early stage, increasing only slightly in amount with time should counterbalance the tendency to shrink, providing volume-stability. A slight stress is advantageous in maintaining this stabi1ity. The possible changes incurred when different formulations exist in contact with various brines must be considered in greater depth for estimating long-term stability.

Results of studies of exploratory mixtures to convert the cements' aluminate phases more fully to AFm and AFt phases have appeared to be promising. Their longer term behaviors should be investigated. This should include the potential effects of reaction with major amounts of calcium sulfate or carbonate, either in initial mixtures or through simulated intrusion of brines. 
Additional experiments should be carried out with clays and zeolites to determine possible trade-offs between best early stage properties, and alternate materials which may take full advantage of trends toward change through longer term reaction with the host rock environment.

Information from other sources including study of old and ancient cementitious materials, recovered field plugs, refined thermodynamic data, additional diffusion experiments, and further high temperature and pressure studies should be directed to providing insight regarding longevity of the above types of seal materials. 


\section{REFERENCES}

American Society for Testing and Materials, 1981. Amual Book of ASTM Standards, Part 14, Concrete and Mineral Aggregates, and Part 13, Cement: Lime: Gypsum.

Ames, L.L.. 1960. 'The Cation Sieve Properties of Clinoptilolite, Amer. Minera 1., Vol. 45, pp. 680-700.

Ames, L.I., 1961. 'Cation Sieve Properties of the Open Zeolites Chabazite, Mordenite, Erionite and C1inoptilolite," Amer. Minera1., Vo1.48, pp. 1120-1131.

Ames, L.L., 1963. 'Mass Action Relationships of some Zeolites in the Region of High Competing Cation Concentrations," Amer. Mineral, Vol. 45, pp. 868882.

Asaga, K. and D.M. Roy, 1980. 'Rheological Properties of Cement Mixes: IV. Effects of Superplasticizers on Viscosity and Yield Stress," Cem. Concr. Res., Vo1. 10, No. 2, pp. 287-295.

ASTM. See American Society for Testing and Materials.

Baes, C.F., Jr., 1981. 'Effects of Water in Salt Repositories,' Technical Progress Report for the Quarter 1 Apri1 $=30$ June, 1981, ONWI-9(81-3), Office of Nuclear Waste Isolation, Battelle Memorial Institute, Columbus, OH, PP. 238-239.

Biggers, J.V. and G.O. Dayton, 1979. 'Brine Migration in Hot-Pressed Polycrystalline Sodium Chloride, 'Topical Report 6 to Office of Nuclear Waste Isolation, Materials Research Laboratory, The Pennsylvania State University, University Park, PA 16802, August.

Bodine, M.W. and R.R. Standaert, 1977. 'Chlorite and I11ite Compositions from Upper Silurian Rock Salts, Retsof, New York." Clays and Clay Minerals, Vo1. 25. pp. 57-71.

Boles, J.R., 1977. 'Zeolites in Low-grade Metamorpic Grades,' Mineralogy and Geology of Natural Zeolties, F.A. Mupton, d., Mineralogical Society of Anexica, pp. 103-135.

Braithwaite, J.W. and M.A. Molecte, 1980. 'Nuclear aste Canister Corrosion Studies Pertinent to Geologic Isolation. Nucl. Chem. Waste Management. Vo1. 1, pp. 37-50.

Breck, D.W., 1974. Zeolite Molecular Sieves: Structure, Chemistry and Use, wiley and Sons, New York, 771 p.

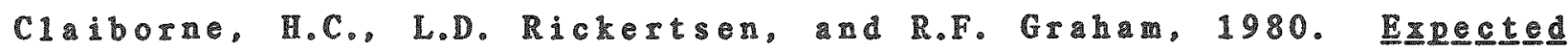
Environments in High-level Nuclear Waste and Spent Fuel Repositorios in Salt, ORNL/TM7201, Oak Ridge National Laboratories, Oak Ridge, TN.

Cohen, B.L., 1977. "The Disposal of Radioactive Wastes from Fission Reactors," Sei. Aner., Vo1. 236, pp. 21-31.

D'Appolonia Consulting Engineers, Inc., 19802. Repository Segling: Eraluation of Materials Research Objectives and Requirements, ONWI-108, 
prepared for Office of Nuclear Waste Isolation, Battelle liemorial Institute, Columbus, OH.

D'Appolonia Consulting Engineers, Inc..1980b. Repository Sealing Design Approach $=1979$. ONWI-55, prepared for Office of Nuclear Battelle Memorial Institute, Columbus, OLE.

Droste, J.B., 1963. 'Clay Mineral Composition of Evaporite Sequences.' Symposium on Salt. North. Ohio Geo1. Soc., Cleveland, OE, pp. 47-54.

Eber1, D., G. Whitney and H. Whoury, 1978. 'Rydrothermal Reactivity of Smectite, Amer. Mineral., Vol.63, pp.401-409.

Fo1k, R.L., 1968. Petrology of Sedimentary Rocks, Hemphill's, Austin, IX.

Forrester, J.A. and C.D. Lawrence, 1961. Jour. Ap1. Chem., Vo1.11, pp.413420.

Fuchtbauer, H. and $\mathbb{E}$. Goldschmidt, 1959. 'Die Tonminera1 der Zechsteinformation, Beitr. Z. Piner. 13. Petrogr., Vol.6. pp.320-345.

Garre1s, R.M. and C.L. Christ, 1965. Solutions, Minera1s, and Equilibsia, Fiarper and Row, New York.

Goto, S. and D. Hoy. Roy, 1981. The Effect of W/C Ratio and Curing Temperature on the Permeability of Hardened Cement Paste. Cem. Concr. Res.n Vo1. 11. No. 4, pp. 575-580.

Grim, R.E., J.B. Droste, and WP. Bradley, 1960. 'A Mized-1ayer Clay Minera1 Associated with an Evaporite," Clays and Clay Minerals, Vo1. 8, pp. 228236.

Grutzeck, M.W., D.M.Roy and B.E.Scheetz, 1981a. 'Microstructures of HighLime F1y Ash Cementitious Mizes, Cemo Coner. Res., Vo1.11, No.2, pp. 291-294.

Grutzeck, M.W., D.M. Roy and B.E. Scheetz, 1981b. 'Hydration liechanisms of Tigh-Lime Fly Ash in Portland Cement Composites," Effects of Flyash Incorporation in Cement and Concrete. S. Dimond, ad., Mat. Res. Soc., University Park, PA, PQ. 92-101.

Grutzeck, M.W., D.M.Roy and D. Wo1 fe-Confer, 1982. 'Mechanstion of Hydation of Portland Cement Composites Containing Ferrosilicon Dust.' Proceedings of the Fourth International Conference on Cement Microscony. G.R. Gouda, ed., Int. Cem. Micros. Assoc., Duncanvi11e, TX, pp. 193-202.

Gulick, C.W., Jr., J.A. Bod, Jr., and A.D. Buck, 1980a. Be11 Canyon Test Cement Grout Development Report. SAND80-1928, Sandia National Laboratory, Albuquerque, NR:

Gulick, C.W., Jr., J.A.Bo2, Jro and A.D.Buck, 1980b. Be1 Canyon Test (BCT) Cement Development Report. SAND80-0358C, Sandia National Labor tory. Albuquerque, NM. 
Jenks, G.H., 1979. Effects of Temperature, Temperature Gradients, Stress and Irradiation on Migration of Brine Inclusions in a Salt Repository. ORNL5526, Oak Ridge National Laboratory, Oak Ridge, TN.

Rastner, M., and $\mathbb{R}$. Siever, 1979. 'Low-temperature Feldspars in Sediuentary Rocks, Amer. Jour. Sci. Vol. 279, pp. 435-479.

K1 ingsberg, C., and J.0. Duguid, 1980. Status of Technology for Isolating High-Leve 1 Radioactive Wastes in Geologic Repositories, Dor/TIC 11207. U.S. Dept. of Energy, Office of Waste Isolation, Washington, DC.

Komarneni. S., 1981. Hydrotherma $1 \mathrm{Stability}$ of $\mathrm{f}-\mathrm{Cs}_{2} \mathrm{U}_{2} \mathrm{O}_{7}$ and $\mathrm{SrZrO}_{3}$ in Fluids: I. Inorg. Nuc1. Chem., Vo1.43, pp. 2833-2837.

Komarneni, S., and D.M. Roy, 1978. 'Effect of Layer Charge and Reat Treatment on Cs Fixation by Layer Silicate Minerals, I. Inorg. Nuc1. Chem. Vol. 40. pp. $893-896$.

Komarneni, S., and R. Roy, 1980. "Hydrothermal Tramsormations in Candidate Overpack Materials and Their Effects on Cesium and Strontium Sorption, Nuc1. Tech., Vo1. 54, pp. 118-122.

Komarneni, S., W.P. Freborn, and C.A, Smith, 1979. 'Simple Cold-weld Sealing of Noble Metal Tubes, Amer. Minera 1., Vo1. 64, pp.650-651.

Langton, C.A., and D.M. Roy, 1980a, Morphology and Microstructure of Cement Paste/Rock Interfacial Regions, 7th Int1. Cong. Chem. Cement, Paris, Vo1. VIII, Communications, pp. VII -127 to VII-133.

Langton, C.A., M.W. Grutzeck, and D.M. Roy, 1980b. 'Chemical and Physical Properties of the Interfacial Region Formed Between Unreactive Aggregate and Iydrothermal1y Cured Cement, Cem. Concr. Res., Vo1. 10, pp. 449-454.

Lounsbury, R.W., 1963. 'Clay Nineralogy of the Salina Formation, Detroit, Michigan.' Symposium on Salt. North. Ohio. Geol. Soc., Cleveland, OR, pp. $56-63$.

Mchedlov-Petrossian, D.P., 1965. Thermodynamik der Silikate. VEB, Berlag.

Meyer, D., and J.J. Howard, eds., 1983. Evaluation of Clays and Clay Minera1s for Application to Repository Sealing, ONWI-486, prepared by D'Appolonia Consulting Engineers, Inc. and Material Research Laboratory, The Pennsylvania State University for Office of Nuclear Waste Isolation, Battelle Memorial Institute, Columbus, OH.

Millot, G., 1970. Geology of Clays, New York, Springer-Verlag, 429 pp.

Nowak, E.J., 1980. The Backil1 as angineered Barrier for Nuclear Wste Managent. Scientiric Basis for Nuclear Vaste Management, Vo1.2. C.J.M. Northrup. ed., Plenum Press, pp. 403-410.

Ogawa, Ko and D.M. Roy, 1981. ${ }^{\prime} C_{4} \mathbb{A}_{3} \bar{S}$ Hydration, Ettringite Formation, and its Expansion Mechansm. I. Expansion; Ettringite Stability, Cem. Concr. Res.. Vo1. 11, No. 5/6, pp. 741-750. 
Ogawa, 5 . and D.M. Roy, 1982. 'C $C_{4} \mathbb{A}_{3}$ Hydration, Ettringite Formation, and its Expansion Mechanism: II. Microstructural Observation of Expansion. Cem. Concr. Res., Vo1. 12. No. 1, pp. 101-110.

Olander, D.R., A.J. Machiels, and S. Yagnik, 1980. Thermal Gradient Migration of Brine Inclusions on Salt, ONWI-208, prepared for office of Nuclear Waste Isolation, Battelle Memorial Institute, Columbus, OH.

Parker, K.M॰, and D.M. Roy, 1982. 'Porosity, Permeability, and Microstructure of Portland Blast-Furnace Slag Cement Pastes.' Bul1. Amer. Cer. Soc., Vo1. 61, No. 3, p. 345.

Perez, M.s 1981. 'Volumetric and Unidimensional Changes of Cementitious Materials, M.S. Thesis, The Pennsylvania State University.

Powers, D.W.. S.J. Lambert, S.E. Shaffer, L.R.Hi11, and W.D. Weart, 1978. Draft Site Characterization Report for the Waste Isolation Power Plant (WIPP). Southeastern New Mexico. Vo1. II, SAND78-1596, Sandia National Laboratory, Albuquerque, NM.

Pusch, R., 1978. High1y Compacted Na-bentonite as Buffer Substance. KBS Teknisk Rapport No. 74, Kärnbränslesäkerhet, Stockholm, Sweden.

Pusch, R., A. Jacobsson, and A. Bergstrom, 1980. 'Bentonite-based Buffer Substances for Isolating Radioactive Waste Products at Grat Depth in Rocks," Underground Disposal of Radioactive llastes, Vo1. I. Proc. of Symposium, Vienna: IAEA, pp. 487-501.

Roy, D.M., B.E. Scheetz, E.L. White, and M. Diamon, 1978. Borehole Cement and Rock Properties Study Part A: Borehole Plugging Cement Studies, ONWI-5, prepared by The Pennsylvania State University for office of Nuclear Waste Isolation, Battelle Memorial Institute, Columbus, $\mathrm{OH}$.

Roy, D.M., M.W. Grutzeck and K. Mather, 1980. PSU/WES Inter laboratory Comparative Methodology Study of an Experimental Cementitious Repository Seal Material, ONWI-198, prepared for Office of Nuclear waste Isolation, Battelle Memorial Institute, Columbus, $\mathrm{OH}$.

Roy, D.M., M.W. Grutzeck, Katharine Mather and A.D. Buck, 1981. PSU/WES Interlaboratory Study of an Experimental Cementitious Repository Seal Materials, oNWI-324, prepared for Office of Nuclear Waste Isolation, Battelle Memorial Institute, Columbus, OH.

Roy, D.M. and G. Idorn, 1982. 'Development of Structure and Properties of Blast Furnace Slag Cement,' Int1. Conf. on Slag and Blended Cement, Birmingham, Al, February.

Roy, D.M., B.E. Scheetz, C.A. Langton, and M.W. Grutzeck, 1982. Selection and Durability of Seal Materials for a Basalt Repository: Preliminary Studies, MRL-C/PSU-022, Materials Research Laboratory, The Pennsylvania State University, University Park, PA, September. 
Sarkar, A.K., M. W. Barnes, and D.M. Roy, 1980. Lomgevity of Borehole and Shaft Sealing Materials. I. Thermodynamic Properties of Cements and Related Phases Applied to Repository Sealing, ONWI-201, prepared by The Pennsylvania state University for Office of Nuclear waste Isolation, Battelle Memorial Institute, Columbus, $\mathrm{OH}$.

Schetz, B.E., D.W. Strickler, M.W. Grutzeck, and D.M.Roy, 1981. 'Physical and Chemical Behavior of Selectively Etched Fly Ashes, Effects of Flyash Incorporation in Cement and Concrete. S. Diamond, ed., Mat. Res. Soc. University Park, PA, pp. 24-33.

Scheetz, B.E., D.M. Roy, E.L. White, and D. Wolfe-Confer, 1980. 'Comparison of Tailored Cement Formulations for Borehole Plugging in Crystalline Silicate Rocks and Evaporite Mineral Sequences. Scientific Basis for Nuclear Waste Management, Vo1. 2, C.J.M. Northrup, Jro, ed., Plenum Press. NY, pp. 437-444.

Setter, N., and D.M. Roy, 19\%8. 'Mechmical Features of Chemical Shrinkage of Cement Paste, Cem. Concr. Res., Vol. 8, No. 5, pp. 623-634.

Spinks, J.W.T., H.W. Baldwin, and T. Thorvaldson, 1952. Cano Jour, Techoo Vo1. 30, pp. 20-28.

Surdam, R.C., 1977. 'Zeolites in closed hydrologic systems, Mineralogy and Geology of Natural Zeolites, FoA Mumpton, ed., Mineralogical Society of Aneric2, Dp. 65-91.

Tabor, D., 1981. 'Principles of Adhesion-Bonding in Cement and Concrete.' Adhesion Problems in the Recrcling of Concrete, P. Kreijger, ed., Plenur Press, NY, pp.63-90.

Tamura, T., and Jacobs, D.G., 1961. 'Improving Cesiur Selectivity of Bentonites by Heat Treatment," Hea1th Physics, Vol. 5, pp. 149-154.

U.S. Department of Energy, 1980. NWTS Criteria for Mined Geologic Disposal of Nuclear Wastes: Site-Qualification Criteria, DOE/NWTS-33(2), Washington, D.C.

Van Olphen, H., and J.J. Fripiat, 1979. Handbook for C1ay Materials and Other Non-metallic Minerals. Pergawon Press, Oxford, 346 pp.

Wakeley, L.D., and D.M. Roy, 1982a. Experimental Salt-Compatible Grouts and Concretes." Bu11. Amer. Cer. Soc. Vo1. 61, No.3, p. 345.

Waley. L.D.s and D.M.Roy. 1982b. 'A Method For Testing the Permeability between Grout and Rock, Cem. Concr. Res., Vol.12, pp. 533-534.

Wakley, L.D., D.M.Roy, and M.W.Grutzeck, 1981 . Experimental Studies of Seal Materials for Potential Use in L Los Medanos-Type Bedded SaIt Repository ON I-325, prepared for Office of Nuclear Viste Isolation. Battelle Memorial Institute, Columbus, OH.

Watey, L.D., B.E. Scheetz, M.V. Grutzeck, ad D.M. Roy, 1981 b. -Characterization of Samples of a Cement-Borehole Plug in Bedded Evaporites from Southeastern New Mexico" Cem. Concr. Res. Vol. 11, No. 1. Pp. 131-142. 
Weaver, C.E., 1958. 'Geologic Interpretation of Argillaceous Sediments.' Bu11. Amer. Assoc. Petro1. Geo1., Vo1. 42, pp. 254-309.

White, W.B., 1981. 'The Chemistry and Physics of Nuclear Waste-Rock Interactions, Task 3: Brine Migration in Salt, Technical Progress Report for the Quarter 1 Apri1 $=30$ June, 1981, ONWI-9 (81-3), Office of Nuclear Waste Isolation, Battelie Memorial Institute, Columbus, OH, pp. $54-55$.

Wu, X., D.M. Roy, and C.A. Langton, 1983. 'Early Stage Hydration of SlagCement,' Cement and Concrete Research, Vo1. 13, No. 2, pp. 277-286. 


\begin{abstract}
APPENDICES
Appendix A contains chemical compositions of the various cements, reactive additives and admixtures used in formulating most of the cementitious formulations given in the text of the report. In some cases no such analyses were available since mixtures were of a very exploratory nature formulated early in the program.

Appendix B consists of microhardness data for most of the mixtures discussed in the text of the report. In general, it is assumed that satisfactory mechanical properties are possible for a mixture having microhardness $\geq 20 \mathrm{~kg} \mathrm{~mm}^{-2}$. The magnitudes of microhardness, like Young's modulus and density are compositionally dependent, as well as dependent upon microstructures (as is the strength). Therefore, differences do no follow exactly the same patterns as the latter. A more $\mathrm{full}$ interpretation will be presented elsewhere.
\end{abstract}


156

Appendix A. Chemical Analysis.

\begin{tabular}{|c|c|c|c|c|c|c|}
\hline \multirow[b]{2}{*}{ Oxide } & \multicolumn{5}{|c|}{ Cements } & \multirow[b]{2}{*}{$\mathrm{H}-9$} \\
\hline & $\begin{array}{c}C-2 \\
\text { EI Toro } \\
\end{array}$ & $\begin{array}{c}C-5 \\
\text { E1 Toro } \\
\end{array}$ & $y-4$ & $H-7$ & $\mathrm{H}-8$ & \\
\hline $\mathrm{SHO}_{2}$ & $21.2 \%$ & $20.7 \%$ & 23.1 & 22.3 & $22.27 \%$ & $22.0 \%$ \\
\hline $\mathrm{Al}_{2} \mathrm{O}_{3}$ & 2.72 & 2.8 & 3.8 & 3.84 & 3.60 & 3.5 \\
\hline $\mathrm{Fe}_{2} \mathrm{O}_{3}$ & 5.17 & 4.80 & 3.83 & 3.80 & 4.01 & 4.19 \\
\hline $\mathrm{CaO}$ & 65.7 & 66.55 & 63.45 & 64.78 & 64.40 & 64.92 \\
\hline MgO & 0.90 & 0.83 & 2.35 & 2.08 & 2.87 & 2.91 \\
\hline $\mathrm{SO}_{3}$ & 2.62 & 2.93 & 2.82 & 1.92 & 1.99 & 1.79 \\
\hline $\mathrm{Na}_{2} \mathrm{O}$ & 0.21 & 0.16 & 0.13 & 0.09 & 0.15 & 0.16 \\
\hline $\mathrm{R}_{2} \mathrm{O}$ & 0.18 & 0.10 & 0.59 & 0.49 & 0.57 & 0.50 \\
\hline $\mathrm{TiO}_{2}$ & 0.13 & 0.10 & 0.19 & 0.19 & 0.17 & 0.21 \\
\hline $\mathrm{P}_{2} \mathrm{O}_{5}$ & 0.05 & 0.07 & 0.10 & 0.14 & 0.11 & $<0.10$ \\
\hline $\mathrm{Mno}$ & 0.22 & 0.05 & 0.02 & 0.015 & 0.02 & 0.020 \\
\hline $\mathrm{BaO}$ & - & -- & -- & 0.03 & - & 0.024 \\
\hline Sro & 0.09 & 0.09 & 0.07 & 0.07 & 0.06 & 0.051 \\
\hline LOT & 0.76 & 0.87 & 0.47 & 0.43 & $-\infty$ & 0.46 \\
\hline Total & 99.86 & 100.05 & 100.92 & 100.18 & 100.22 & 100.74 \\
\hline $\mathrm{CO}_{2}$ & 0.26 & 0.55 & 0.45 & 0.21 & 0.48 & 0.24 \\
\hline
\end{tabular}

Reactive Additives, B Compounds

\begin{tabular}{|c|c|c|c|c|c|c|c|c|c|}
\hline oxide & B15 & B.17 & B24 & B25 & 826 & B27 & B31 & B44 & B51 \\
\hline $\mathrm{SiO}_{2}$ & 40.6 & 87.47 & 97.2 & 50.2 & 33.2 & 96.0 & 94.3 & 37.8 & 92.6 \\
\hline $\mathrm{Al}_{2} \mathrm{O}_{3}$ & 17.4 & 1.05 & 0.10 & 27.0 & 17.6 & 0.10 & 0.36 & 20.2 & 0.05 \\
\hline $\mathrm{Fe}_{2} \mathrm{O}_{3}$ & 5.05 & 2.28 & $<0.1$ & 13.8 & 6.03 & -0.1 & 0.66 & 5.79 & 0.1 \\
\hline $\mathrm{CaO}^{3}$ & 26.86 & 0.66 & 0.13 & 1.82 & 29.91 & 0.12 & 0.27 & 25.2 & 0.08 \\
\hline $\mathrm{MgO}$ & 3.58 & 1.17 & 0.16 & 0.84 & 5.07 & 0.13 & 1.42 & 4.51 & 0.20 \\
\hline $\mathrm{SO}_{3}$ & 1.40 & 0.34 & $\ldots$ & -- & 2.77 & -- & -- & 1.75 & - \\
\hline $\mathrm{Na}_{2} \mathrm{O}$ & 0.96 & 0.96 & 0.20 & 0.24 & 1.03 & 0.1 & 0.76 & 1.43 & 0.1 \\
\hline $\mathbb{K}_{2} 0$ & 0.72 & 1.83 & 0.42 & 2.45 & 0.41 & 0.45 & 1.11 & 0.56 & 0.47 \\
\hline $\mathrm{TiO}_{2}$ & 1.24 & 0.01 & $<0.1$ & 1.40 & 1.55 & $<0.1$ & $<0.1$ & 1.44 & $<0.1$ \\
\hline $\mathrm{P}_{2} \mathrm{O}_{5}^{2}$ & 0.65 & 0.10 & 0.07 & 0.49 & 0.95 & 0.07 & 0.05 & $-\infty$ & 0.02 \\
\hline $\mathrm{MnO}^{3}$ & 0.026 & 0.11 & 0.010 & 0.034 & 0.034 & 0.010 & 0.023 & 0.018 & 0.003 \\
\hline BaO & 0.58 & $<0.01$ & $-\infty$ & -- & 0.84 & -- & $\ldots$ & -- & -- \\
\hline Sro & 0.23 & 0.02 & $-\infty$ & -- & 0.37 & -- & -- & $-\infty$ & -- \\
\hline LOI & 0.47 & 4.06 & -- & -- & 0.44 & $-\infty$ & - & 0.74 & - \\
\hline Total & 99.77 & 100.06 & 98.25 & 98.27 & 100.20 & 96.80 & 98.95 & 99.43 & 93.42 \\
\hline \multirow[t]{2}{*}{ other } & & $\begin{array}{r}\text { carbon } \\
1.84\end{array}$ & & $\begin{array}{l}\mathrm{Ba} \\
1250 \mathrm{ppm}\end{array}$ & & & & & \\
\hline & & & & $\begin{array}{l}\mathrm{Sr} \\
900 \mathrm{ppm}\end{array}$ & & & & & \\
\hline $\mathrm{CO}_{2}$ & 0.17 & $<0.05$ & $-\infty$ & -- & 0.22 & $-\infty$ & -- & 0.07 & $-\infty$ \\
\hline
\end{tabular}

No analysis available for $B 3, B 5, B 7, B 8, B 19, B 23, B 31$.

Adrixtures

\begin{tabular}{|c|c|c|c|c|c|c|c|}
\hline & $\mathrm{A} 3$ & A27 & A28 & A29 & A31 & A36 & A41 \\
\hline loss at $105^{\circ} \mathrm{C}$ & $54.5 \%$ & 斗果 & $2 x$ & $* *$ & 急果 & $57.4 \%$ & $\approx$ \\
\hline LTA* & 35.3 & & & & & 33.6 & \\
\hline$\$$ & 11.2 & & & & & 11.0 & \\
\hline N & 0.02 & & & & & 0.02 & \\
\hline $\mathrm{C}$ & 46.3 & & & & & 46.6 & \\
\hline $\mathrm{H}$ & 3.16 & & & & & 3.25 & \\
\hline \multicolumn{8}{|l|}{ LTA } \\
\hline $\mathrm{Ca}$ & 0.1 & & & & & 3.8 & \\
\hline $\mathrm{Na}$ & 45.6 & & & & & 52.1 & \\
\hline $\mathrm{Mg}$ & 0.01 & & & & & 0.01 & \\
\hline
\end{tabular}

*Low temperature ash. No analysis available. 
Appendix B. Microhardness, $\mathrm{kg} / \mathrm{mm}^{2}$.

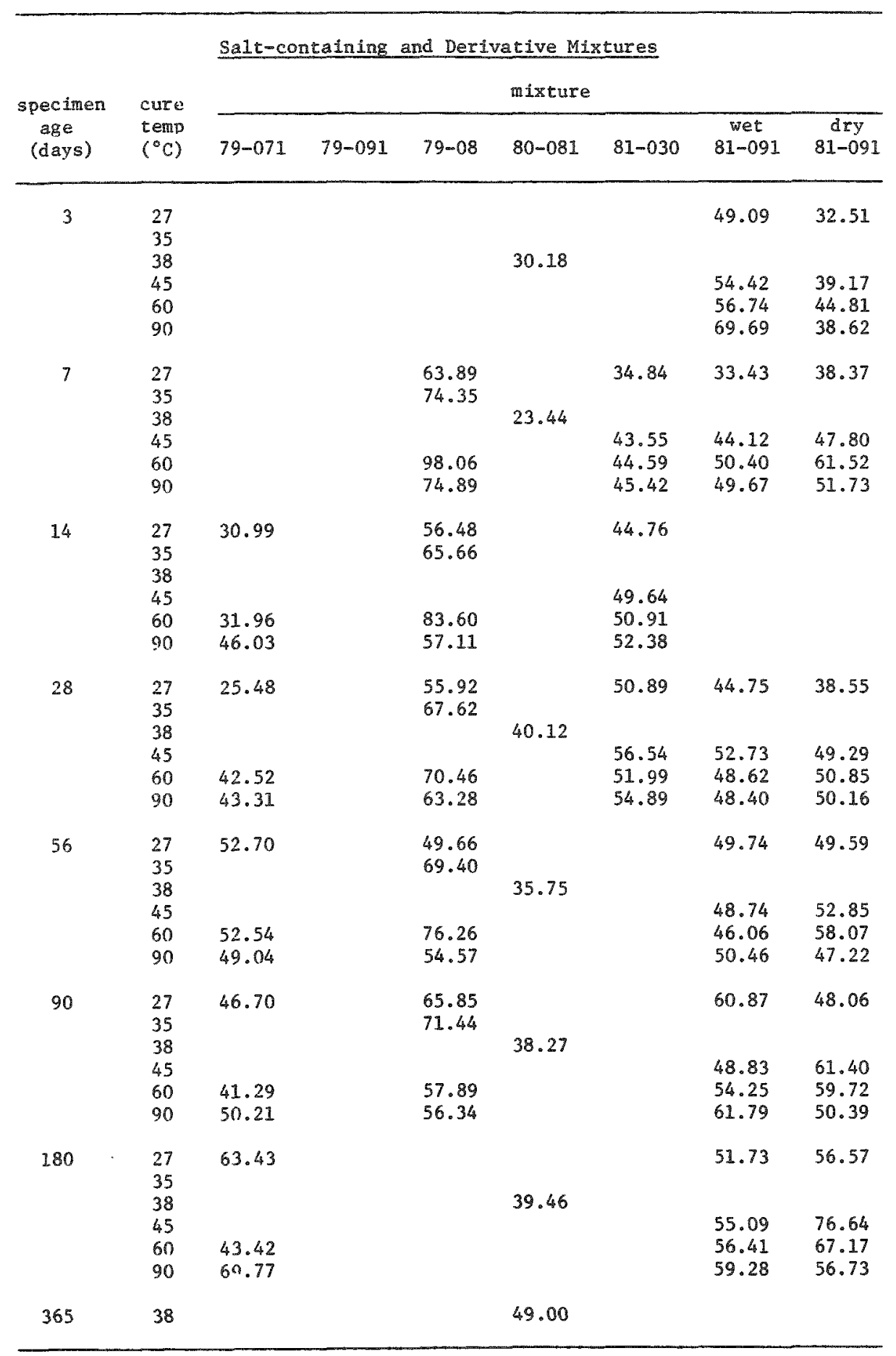


Appendix B (continued)

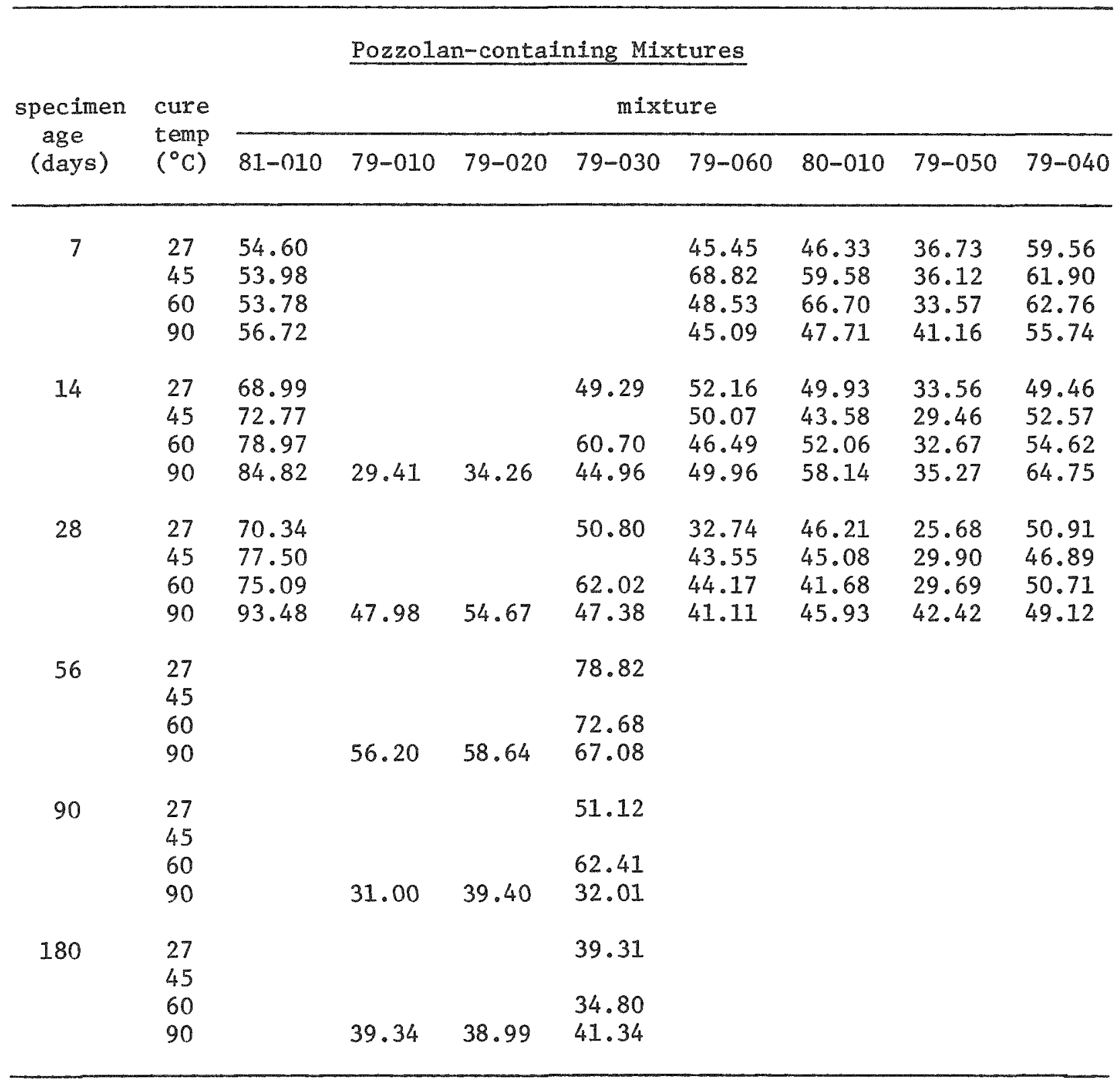




\section{$159 / 1000$}

Appendix B (continued)

\section{Exploratory Mixtures}

\begin{tabular}{|c|c|c|c|c|c|c|c|c|c|}
\hline \multirow{2}{*}{$\begin{array}{c}\text { specimen } \\
\text { age } \\
\text { (days) }\end{array}$} & \multirow{2}{*}{$\begin{array}{l}\text { cure } \\
\text { temp } \\
\left({ }^{\circ} \mathrm{C}\right)\end{array}$} & \multicolumn{8}{|c|}{ mixture } \\
\hline & & $81-141$ & $81-101$ & $80-020$ & $80-030$ & $80-040$ & $80-050$ & $81-121$ & $81-111$ \\
\hline \multirow[t]{4}{*}{3} & $\begin{array}{l}27 \\
38\end{array}$ & 3808 & 3528 & & & & & 36.95 & 33.09 \\
\hline & 45 & & & & & & & 53.44 & 35.36 \\
\hline & 60 & & & & & & & 56.47 & 32.85 \\
\hline & 90 & & & & & & & 58.64 & 43.97 \\
\hline \multirow[t]{5}{*}{7} & 27 & & & 52.26 & 53.82 & 33.47 & 52.45 & 56.92 & 32.04 \\
\hline & 38 & 48.10 & 42.57 & & & & & & \\
\hline & 45 & & & 61.45 & 55.21 & 39.16 & 52.95 & 55.62 & 40.09 \\
\hline & 60 & & & 67.53 & 51.81 & 42.10 & 72.96 & 64.26 & 48.55 \\
\hline & 90 & & & 65.79 & 58.05 & 50.38 & 56.07 & 59.64 & 60.24 \\
\hline \multirow[t]{5}{*}{14} & 27 & & & 55.51 & 52.66 & 44.28 & 53.41 & & 31.46 \\
\hline & 38 & & 50.45 & & & & & & \\
\hline & 45 & & & 63.80 & 63.73 & 48.08 & 54.68 & & 43.53 \\
\hline & 60 & & & 61.27 & 62.13 & 48.97 & 56.96 & & 43.29 \\
\hline & 90 & & & 70.16 & 63.13 & 50.53 & 59.00 & & 41.60 \\
\hline \multirow[t]{5}{*}{28} & 27 & & & 64.31 & 55.03 & 47.93 & 61.32 & 64.13 & 36.47 \\
\hline & 38 & 53.47 & 48.35 & & & & & & \\
\hline & 45 & & & 65.83 & 58.06 & 51.63 & 53.45 & 64.18 & 46.97 \\
\hline & 60 & & & 73.89 & 59.46 & 52.04 & 59.53 & 59.16 & 55.61 \\
\hline & 90 & & & 79.05 & 63.26 & 60.80 & 53.47 & 59.30 & 55.63 \\
\hline \multirow[t]{5}{*}{56} & 27 & & & & & & & 67.78 & 54.55 \\
\hline & 38 & 48.03 & 52.17 & & & & & & \\
\hline & 45 & & & & & & & 62.04 & 48.27 \\
\hline & 60 & & & & & & & 75.21 & 53.18 \\
\hline & 90 & & & & & & & 66.12 & 45.58 \\
\hline \multirow[t]{5}{*}{90} & 27 & & & & & & & & 63.18 \\
\hline & 38 & & & & & & & & \\
\hline & 45 & & & & & & & & 61.77 \\
\hline & 60 & & & & & & & & 60.38 \\
\hline & 90 & & & & & & & & 57.92 \\
\hline
\end{tabular}




\section{DISTRIBUTION LIST}

ACERES AMERICAN INC

A. S. BURGESS

ROBERTH. CURTIS

R. STRUBLE

AREOSPACE CORP

BARRETT R. FRITZ

AGBAEIAN ASSOCIATES

CHRISTOPHER M. ST JOHN

ALABAMA DEPT OF ENEREY

CAMERON MCDONALD

ALABAMA STATE GEOLOGICAL SURVEY THORNTON L. NEATHERY

ALLIED GENERAL NUCLEAR SERVICES P. F. HIGHBERGER

M. A. KOLB

AMARILIO PUBLIC LIBRA

AMERICAN FRIENDS SERVICE COMMITTEE WILLIAM REYNOLDS

AMERICAN NUCLEA DOTTIE SHERMAN

APPLIED MECHANICS INC GRAHAM G. MUSTOE. JOHN R. WILLIAMS

ARGONNE NATIONAL LABORATORY DAVID F. FENSTER

WYMAN HARRISON

I. HOWARD KITTEI MARTIN J. STEINDLER

ARINC RESEARCH CORP

H. P. HIMPLER

ARIZONA STATE UNIVEISITY

PAUL KNAUTH

ARTHUR D. UTTLE INC CHARLES R. HADLOCK

ATOMIC ENIRGY CONSULTANTS DONALD G. ANDERSON

ATOMIC ENERGY CONTROL WOARD. CANADA

1.L. WALLACH

ATOMIC ENERGY COUNCIL - RPEUELIC OF CHINA

C. S. YEH

ATOMIC ENHEGY OF CANADA ITD

T. CHAN

M. O. LUKE

ANN QUINN

E.P. SARGENT

ATOMIC ENERGY RESEARCH TSTABLSHMENT

- UNITED KINGDOM

P. J. BOURKE

ATOMIC INDUSTRIAL FORUM INC

EMANUEL GORDON

AUSTRALIAN ATOMIC ENERGY COMMISSION

BABCOCK \& WLLOX

INFORMATION SERVICES

BATTELE COLUMBUS DIVISION

JOHN T. MCGINNIS

JEFFREY L. MEANS

STEPHEN NICOLOSI

THOMASM. TRAINER

KENNETH R. YATES

BECHTEL GROUP INC

LESLIE I. JARDINE

R. C. LOVINGTON

N. A. NORMAN

GERALD L. PALAU

U. YOUNG PARK

RICHARD I. TOSETTI

CHING LIU WU

RECHTEL NATIONAL INC

TOM S. BAER

DON B. CRANDALL
MENOIX FIEID FNGINEERING CORP

CHARLES A. JONES

MICHAEL H. MOBLEY

JOHN C. PACER

RERKELEY GEOSCIENCES/HYDROTECHNIQUE ASSOCIATES

BRIAN KANEHIRO

BHABHA ATOMIC RESEARCH CENTER - INDIA V. SUKUMORAN

BEENVULLE PARISH LIBRARY

BLOXI PUBLIC IRBRARY

RLACK \& VEATCH

M. JOHN ROBINSON

BOEING ENGINEERING AND CONSTRUCTION

COMPANY

R. B. CAIRNS

BRENG SYSTEMPLANUNG - W. GERMANY

H. D. BRENK

BRIIISH NUCLEAR FUELS LTD

R. 5. WILKS

BROOKHAVEN NATIONAL LARORATORY

M. S. DAVIS

DELYLE EASTWOOD

SANDRA G. LANE

P. W. LEVY

PETER SOO

HELEN TODOSOW

BUNDESANSTALT FUR GEOWISSENSCHAFTEN

UND TOMSTOFEE - W. GERMANY

MICHAEL LANGER

HELMUT VENZI AFF

BUNDESMINISTEE

TECHNOLOGIE - W. GERMANY

ROLF-PETER RANDL

BUREAU DE MECHEFCHES GEOLOGIQUES ET

MUNRERES - FRANCE

BERNARD FEUGA

PIERRE F. PEAUDECERF

DURNS AND ROE INDUSTRIAL SERVICES CORP JOHN PIRRO

C.F.H.F.

BILL DUESINC

C.N.A. UNDERGROUND CONSTRUCTION CONSULTANTS

D. H. YARDLEY

CALIPORNAA DEPT OF CONSERVATION PERRY AMIMITO

CALIFORNAA DEPT OF HEALTH SERVICES BEVERLEE MVERS

CALITORNIA DIVISION OF MINES \& GEOLOGY ROBERT H. SYONOR

CALFORNIA INSTITUTE OF TECHNOLOGY LEON T. SILVER

CAMP, DRESSER, AND MCKEE INC WATER RESOURCES DIVISION

CANYONLANDS NATIONAL PARE PETER L. PARRY

CAPIIAL AREA GROUND WATER CONSERVATION COMMISSION A. N. TURCAN, IR.

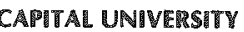
VICTOR M. SHOWALTER

CASTLE VALLEY ORCHARDS CARL ANDERSON

CAYUGA LAKE CONSERVATION ASSOCIATION INC

D. S. KIEFER

CENTERR FOR ENVIIRONMENTAL

INFORAMATON INE FREDERICK W. STOSS
CENTRE D ETUDE DE I ENERGIE NUCLEAIRE ELGIUM RENE HEREMANS

CENTRE D INRORMATIQUE GEOLOGIQUE FPANCE

GHISLAIN DEMARSILY

CITIZENS ASSOCIATION FOR SOUND ENEEG IUANITA ELLIS

CITIZENS FOR A BETTED ENYIRONMENT JOANNA HOELSCHER

CITIZENS INSTITUTE FOR A POSITIVE ENERGY POLICY LINDSAY AUDIN

CLARR UAIVERSTTY JEANNE X. KASPERSON

COLORADO GEOLOGICAL SURVEY JOHN W. ROLD

COLORADO SCHOOL OF MINES W. HUSTRULID

CONNECTACUT GOVERNORS OFFICE MARY M. HART

CONROY ENGINEERING PETER CONROY

CONSOIL ASSOCIATES DAVID A. LEE

CONSOLDATED EDISON COMPANY OE NEW YORE INC JOHN OTOOLE

COPPE/UFRI - BRAZIL LUIZ OLIVIERA

CORNELL UNIVEFSITY

JOHN BIRD

ARTHUR L. BLOOM

DUANE CHAPMAN

FRED H. KULHAWY

ROBERT POHL

CORTLAND COUNTY MEALTH DEPT

$$
\text { J. V. FEUSS }
$$

D.

KARL I. ANANIA

DALTON, DALTON NEWPORT MARIA R. EIGERMAN

DAMES \& MOODE

RON KEAR

CHARLES R. LEWIS

O.L. OZTUNOLI

DAPPOLONIA CONSULTING ENGINEE LISA K. DONOHUE

ABBY FORREST

AMINA HAMDY

PETER C. KELSALL CARL E. SCHUBERT

DAWCON MANAGEMENT CONSUITING SERVICE

DAVID A. WEBSTER

DEAF SMITH COUNTY HIRRARY

DELAWARE CUSTOM MATERREL INC HOWARD NOVITCH

DELAWARE GEOLOGICAL SURVEY ROBERT R. JORDAN

DEPT OF ENERGY, MINES AND RESOURCES CANADA

A. 5. JUDGE

DIXON ASSOCIATES J. DONALD DIXON

DUKE UNIYESSTIY THOMAS DAVIS

DUNN GEOSCIENCE COR WILLIAM E. CUTCLIFFE

DYNATECH R/D COMPANY STEPHEN E. SMITH 
E.I. DU PONT DE NEMOURS \& CO D H TURNO

E.LH. PUBLICATIONS - THE RADIOACTIVE EXCHANGE

HELMINSKI \& WILKEN

E.R. JOHNSON ASSOCIATES INC

$$
\text { E R JOHNSON }
$$

G L JOHNSON

EARTH RESOURCE ASSOCIATES INC SERGE CONZALES

EARTH SCIENCES CONSULTANTS INC HARRY L CROUSE

EAST COMPANY INC RAYMOND PEREZ

EAST TENNESSEE STATE UNIVERSITY ALBERT F IGLAR

ERASCO SERVICES INC ZUBAIR SALEEM RAYMONDH SHUM

ECOLOGY CENTER OF LOUISIANA ROSS VINCENT

EDISON EAECTRIC INSTITUTE R E L STANFORD

EDS NUCLEAR INC C SUNDARARAJAN

EG Q GIDAHO INC ROGER A MAYES M D MCCORMACK

ELEKTRIZITAETS-GES. LAUFENBURG SWITZERLAND H N PATAK

ELSAM - DENMARK A $\checkmark$ JOSHI ARNE PEDERSEN

ENERCOR INC JOHN RODOSEVICH

ENERGY FUELS NUCLEA R INC DON M PILLMORE

ENERGY INC

ENERGY RESEARCH GROUP INC MARC GOLDSMITH

ENGINEERS INTERNATIONAL INC FRANCIS S KENDORSKI

ENVIRONMENT CANADA CLAUDE BARRAUD

ENVIRONMENTAL POLICY INSTITUTE DAVIDM BERICK FRED MILLAR

ENVIROSPHERE COMPANY ROGER G ANDERSON KE LIND-HOWE

EXXON NUCLEA COMPANY INC GERALD L RITTER

EXXON NUCLEAR IDAHO COMPANY INC NATHAN A CHIPMAN ROGER N HENRY W B KERR GARY WAYMIRE

FENIX \& SCISSON INC JOSE A MACHADO CHARLENE U SPARKMAN

FLORIDA DEPT OR ENVIRONMENTAL REGULATION HAMILTON OVEN

FLORIDA INSTITUTE OF TECHNOLOGY JOSEPH A ANGELO, IR

FLORDA POWER \& LIGHT COMPANY JAMES R TOMONTO

FLORIDA STATE UNIVERSITY JOSEPH F DONOGHUE
FLUOR ENGINEERS \& CONSTRUCTORS INC

RAYMOND I DUGAL

VINCENT I KAVLICK

JOAN V MCCURRY

FORD, BACON \& DAVISINC ROBERT D BAIRD

DARRELL H CARD ROBERTF OVERMYER BURTON I THAMER

FOSTER-MILLER ASSOCIATES INC NORBERT PAAS

FOX CONSULTANTS INC MIKEE BRAZIE

FREESTONE COUNTY COURTHOUSE SAM BOURNIAS

FREUE UNIVERSITAET BERUIN HANSKARL BRUEHL

FRIENDS OF THE EARTH LOUIS BUCKLIN RENEE PARSONS

GAEIE BETTS BURTON MEMORIAL UERARY

GENERAL ATOMIC COMPANY ROBERT M BURGOYNE ROBERT J CAMPANA H C CARNEY MICHAEL STAMATELATOS

GEO/RESOURCE CONSULTANTS INC ALVINK JOE IR

GEOLOGICAL SURVEY OR CANADA JEFFREY HUME LIBRARY

GEOLOGICAL SURVEY OF NORWAY SIGURD HLSEBY

GEORESULTS INC DAVID SNOW

GEORGETOWN CONSURTING GROUP SUSAN SHALAGAN

GEORGIA INSTITUTE OF TECHNOLOGY MELVIN W CARTER GEOFFREY G EICHHOLZ ALFRED SCHNEIDER CHARLESE WEAVER

GEOTECHNICAL ENGIAEERS INC RONALD C HIRSCHFELD

GEOTHEERMAL ENERGY INSTUTUTE DONALD F $X$ FINN

GEOTRANS JAMES MERCER

GERMANTOWN FRIENDS SCHOOL HERB BASSOW

GESELLSCMAFT F. STRAMLEN U. UMWELTFORSCHUNG M.B.H. - W. GER WANY

WOLFGANG BODE

NORBERT FOCKWER

HANS W LEVI

H MOSER

GILBERT/COMMONWEALTH JERRY L FLLIS

GOLDER ASSOCIATES DONALDM CALDWELL I W VOSS

GOLDER ASSOCIATES - CANADA CLEMENTM K YUEN

GRAND COUNTY MIGH SCHOOL URRARV

GRAND COUNTY PUBLIC UREARY

GRIMCO DONALD H KUPFER

GSE/NUCLEAR OMAHA PUBLIC POWER DISTREICT

JOHNK NFIAD
GTC GROLOGIC TESTING CONSULTANTS LTD CANADA JOHN F PICKENS

GULF INTERSTATE INC THOMAS / HILL

GULF STATES UTULTTES COMPANY IOHNE BARRY E LINV DRAPER

H \& R TECHNICAL ASSOCIATES INC WILLIAM R RHYNE

H-TECH LABORATORIES INC BRL CF HARTENBAUM

HAHN-MEITNER-INSTITUT FUR KERNFORSCHUNG BERLIN MLAUS ECKART MAASS

HALEY AND ALUTICH INC IANICE HIGHT

MANFORD ENGINEERING DEVELOPMENT LABORATORY ROBERTEINZIGER R L. KNECHT W E ROAKE

MARDING LAWSON ASSOCIATES FRANR C KRESSE

HARVARO UNIVERSTTY CHARLES W BURNHAM DADE W MOELLER RAYMOND SIEVER

HATTIESEURG PUPLIC LIREARY

MIGH PLAINS UNDERGROUND WATER DIST TROY SUBLETT

HIGH PLAINS WATER DISTRICI DON MCRFYNOIDS DON D SAITH A WAYNE WYATT

HIRAM COLEGE JAMES W COWDEN

HTACHI WORKS, HITACHI LTO MAKOTO KIKUCHI

HOUGH-NORWOOD HEALTH CARE CENTER GEORGEH BROWN M D

BDAHO WUIEAU OF MINES AND GEOLOGY EARL H BENNETT CHARLES R KNOWLES

IDAHO DEPT OF HEALTH AND WELFARE ROBERT D FUNDERBURG

HLLINOIS ATOMIC ENERGY COMMISSION DAN L WILLIAMS

ULLNOIS DEPT OF NUCLEAR SAFETY TERRY R LASH MILTON ZUKOR

ILLNOIS STATE GEOLOGICAL SURVEY ROBERT E BERCSTROM E DONALD MCKAY, III

IMPERBAA COLLGE OR SCIENCE AND

TECHNOLOGY - ENGLAND B \& ATKINSON

INDIANA UNIVERSTTY J B DROSTE HAYDN H MURRAY

INDUSTIIIAL POWER COMPANY ITD FPRLAND VEIJO RYHANEN JUKKA-PEKKA SALO

INSTITUT FUR TIEFLAGERUNG - W. GERMANY WERNT BREWITZ

$H$ GIES

KLAUS KUHN

E R SOLTER

INSTHTUTE FOR CHEMICAL TECHNOLOGY - W. GERMANY REINHARD ODOI 
INSTITUTE OF GEOLOGICAL SCIENCES ENGLAND STEPHEN THOMAS HORSEMAN

INSIITUTE OF RADIATION PROTECTION FINLAND

KAI IAKOBSSON

INTERA ENVIRONMENTAL CONSULTANTS INC F I PEARSON IR ROBERT WILEMS

INTERNATIONAL ATOMIC ENERGY AGENCY AUSTRIA

EVERETT R IRISH

FRANK A OHARA

INTERNATIONAL ENERGY ASSOCIATES LTD BLYTHE K LYONS

INTERNATIONAL ENERGY SYSTEMS CORP JOHN A BOWLES

INTERNATIONAL ENGINEEERING COMPANY INC

TERRY L STEINBORN

MAX ZASLAWSKY

INTERNATIONAL RESEARCH AND

EVALUATION

R DANFORD

INTERNATIONAL SALT COMPANY

LEWISP BUSH

IOHN VOIGT

IOWA STATE COMMERCE COMMISSION ROBERT / BUCKLEY

IOWA STATE UNIVERSITY MARTIN C EDELSON BERNARD I SPINRAD

IRT CORP I STOKES

ISMES - ITALY

F GERA

ISETUTOO SPERMMENTALE MODELLI E

STRUTTURE S.P.A. - ITALY NEIL A CHAPMAN

J. L. MAGRUDER \& ASSOCIATES I L MAGRUDER

J.F.T. AGAPITO \& ASSOCIATES INC MICHAEL P HARDY

IACKSON METMOPOLITAN LIBRARY

IACKSON STATE UNIVERSITY ESTUS SMITH

IACKSON-GEORGE REGIONAL LHFARY

JAPAN ATOMIC ENERGV RESEARCH INSTITUTE TARO ITO

HARUTO NAKAMURA

IAYL. SMITH COMPANY INC JAYL SMITH

IGC CORPORATION - IAPAN MASAHIKO MAKINO

IOHNS HOPRINS UNIVERSITY JARED L COHON

IONAT RESEA RCH CENTRE - ITALY FRANCESCO GIRARDI

IONES COUNTY JUNIOR COULEGE LIBMARY

MORDAN GORRHLL ASSOCIATES JOHN D TEWHEY

YAISEM ENGINEERS INC W I DODSON H L JULIEN

KALAMAZOO COLIEGE RALPH M DEAL

KANSAS DERT OF HEALTH AND ENVMONMENT GERALD W ALLEN

MANSAS STATE GEOLOGICAL SURVEY WILLIAM W HAMBLETON
KARABRANSLESAKERHET - SWEDEN

LARS B NILSSON

KELLER WREATH ASSOCIATES

FRANK WREATH

KEPNFORSCHUNGSZENTRUM KARLSE UHE

GMBH - W. GERMANY

$K$ D CLOSS

R KOESTER

KIHN ASSOCIATES

HARRY KIHN

KLM ENGINEERING INC

B GEORGE KNIALEWYCZ

LANCASTER AVENUE LIBRARY

F M CALVARESI

LAWRENCE BERKELEY LABORATORY

$1 O H N$ A APPS

THOMAS DOE

DONALD RONDEAU

ROBIN SPENCER

I WANG

LAWRENCE LIVERMORE NATIONAL

LABORATORY

LYNDEN B BALLOU

EDNAM DIDWELL

HUGH HEARD

FRANCOIS E HEUZE

DANA ISHERWOOD

R CARROLL MANINGER

LAWRENCE D RAMSPOTT (2)

R N SCHOCK

W G SUTCLIFFE

TECHNICAL INFORMATION DEPARTMENT L.53

LEHIGH UNIVERSITY

D R SIMPSON

LOCKHEED ENGINEEING \& MANAGEMENT

COMBANY

STEVE NACHT

LOS ALAMOS NATIONAL LABORATORY

ERNEST A BRYANT

$P$ L BUSSOLINI

GEORGE A COWAN

BRUCER ERDAL

WAYNE R HANSEN

CLAUDE HERRICK

W C MYERS

DONALD T OAKLEY

K K S PILLAY

JOE SMYTH

KURT WOLFSBERG

IOS ALAMOS TECHNICAL ASSOCIATES INC $R$ I KINCSBURY

LOUISIANA DEPT OF NATURAL MESOURCES B IIM PORTER FRANK SIMONEAUX

LOUISIANA DEPT OF TRANSPORTATION \& DEVELOPMENT GEORCE H CRAMER, 11

LOUISIANA GEOLOGICAL SURVEY PEGGY ROONEY AUTIN CHARLES G GROAT SYED HAQUE

LOUISIANA GOVERORS OFFICE DENNIS DAUGHERTY

LOUISIANA NUCLEAME ENERGY DIVISION 1 HALL BOHLINGER (3)

LOUESIANA STATE UNIVERSITY IIMMIE H HOOVER

COUISIANA TECH UNIVERSSTY LIBRARY

IOUISIANA TECHNICAL UNIVERSITY R H THOMPSON
LOWENSTEIN, NEWMAN, REIS \& AXELRAD MICHAEL A BAUSER

MAINE WUREAU OF HEALTH DONALD C HOXIE

MAINE GEOLOGICAL SURVEY WALTER ANDERSON

MARYLAND GEOLOGICAL SURVEY KENNETH N WEAVER

MASSACHUSETTS INSTITUTE OF

TECHNOLOGY

JOHN DEUTCH

TED GREENWOOD

RICHARD K LESTER MARSHA LEVINE

MATERIALS RESEARCH LABORATORY LTD CANADA

S SINGH

MCMASTER UNIVERSITY - CANADA

L W SHEMILT

MELIEN GEOLOGICAL ASSOCIATES INC FREDERIC F MELIEN

MEMBERS OF THE GENERAL PUBLIC

JAMES BOYD

IACK BRANDT

STEPHEN 5 BRIGGS

STEVE CONEWAY

IIM CONKWRIGHT

G COOKE

ROBERT DUDEK

DOROTHY FORD

CARL A GIESE

SHIRLEY M GIFFORD

STEPHEN L GILLETT

DARYL GLAMANN

OSWALDH GREAGER

DOUGLASH GREENIEE

IOAN GREGOR

ALF H GRENNARD

RONALD GRONNEBERC

KENNETH GUSCOTT

C F HAIEK

A $M$ HALE

KENNETH S JOHNSON

THOMAS H LANGEVIN

JOE MADIA

MAX MCDOWELL

A ALAN MOGHISSI

JAMES B MUCKERHEIDE

ALAN D PASTERNAK

SHAILER S PHILBRICK

ROGER E POWERS

MARTIN RATHKE

CHRIS RICH

JERRY SHEPPARD

PAUL SHEWMON

JOHNNY SLUDER

M I SZULINSKI

GORDON THOMPSON

W VON BLACK

GARY WAGNER

A E WASSERBACH

ROBERT WEESE

IIMMYL WHITE

RICHARD I WILLIS

STEPHEN G ZEMBA

MEMORIAL UNIVERSITY OF NEWFOUNDLAND JOHNE GALE

MESA COUNTY PURLIC LRRAREY

GEORGE VAN CAMP

MICHAEL XAKER, IR. INC

C I TOUHILL 
MICHIGAN DEPT OF NATURAL RESOURCES R. THOMAS SEGALL

MICHIGAN DEPI OF PUMLIC HEALTH GLORGE W. BRUCHMANN

MICHIGAN DIST TICT HEALTH DEFT NO. 4 EDGAR KREFT

MICHIGAN GEOLOGICAL SUFVEY ROBERT C. REED

MICHUAN STATE UNUYERSTTY WILLIAM C. TAYLOR

MECHIGAN TECHAHCAL UHAVESSTY DAES. YOUNC

MUNERALS WEST INC STEVE NIELSON

MINNESOTA GEOLOGICAL SURVEY MATT S. WALTON

MINNESOTA STATE ENERGY AGENCY DAVID BULLER

MISSISSIPPI ATTORNEY GENERALS OFFICE MACK CAMERON

MESISSIPPI BUREAU OF GEOLOGY MICHAEL B. E. BOGRAD

MISSISSIP III CITIZENS AGAINST NUCLEAR DISPOSAL

STANLEY DEAN FLINT

MISSISSIPPI DEPT OF ENERGY AND

TIRANSPORTATION JOHN W. GREEN (3)

MISSISSIPFI DEPT OF NATURAL RESOURCES ALVINR. BICKER, IR. CHARLES L. BLALOCK CURTIS W. STOVER

MISSISSIPPI DEFT OF WILDLEE CONSERVATION KENNETH L. GORDON

MISSISSIPPI EMERGENCY MANAGEMENT AGENCV

IAMES E. MAHER

MISSISSIPPI MINERAL RESOURCES INSTTUUTE

MISSISSIPPI POWER \& UGHT ROBERT SHADDIX

MISSISSIPPPI STATE ROA EDDIE S. FUENTE GUYR. WILSON

MISSISSIPPI STATE HOUSE OF REPRESENTATIVES

TERRELL BRFLAND

E. FRED DOBBINS

HILLMAN TEROME FRAZIER

JERRY OKEEFE

MISSISSAPPI STATE SENATE

MARTINT. SMITH

THEOOORE SMITH

MISSISSIPPI STATE UNIVERSITY VICTOR L. ZITTA

MUTRE CORE LESTER A. ETTLINGER

MONTANA RUREAU OF MINES AND GEOLOGY

EDWARD C. BINGLER

MONTICELLO MIGH SCHOOL LMFARY MEDIA CENTER

MOREISON-LNUDSEN COMPANY INC SERGI KAMINSKY

NAGRA - SMITZERLAND MARLIES KUHN

NATHONAL ACADEMY OF SCIENCES JOHN T. HOLLOWAY HAROLD L. IAMES
NATIONAL AERONAUTICS AND SPACE AOMUNISTRATION MICHAEL R. HELFERT

NATIONAL MOAED FOR SPENT NUCLEAR FUEL, KARNBRANSLENAMDEN - SWEDEN NILSRYDELL

NATIONAL EUREAU OF STANDAMDS

RILEYM. CHUNG

LEWIS H. GEVANTMAN

WILLIAM P. REED

NATIONAL SCIENCE FOUNDATION ROYALE. ROSTENBACH

NATURAL RESOURCES DERENSE COUWCIL THOMAS B. COCHRAN

NAYAL WEAPONS STATION EARLE GENNARO MELLIS

NEYADA OFFICE OF COMMUNITY SERVICES 1. HAWKE

NEW ENGLAND NUCLEAR CORP KERRY BENNERT CHARLES B. KILLIAN

NEW IERSEY DEPT OF ENVIRONMENTAL PROTECTION IEANETTE ENG

NEW MEXICO BUREAU OF GEOLOGY BILL HATCHELL

NEW MEXICO BUREAU OF MINES AND MINERAL RESOURCES FRANK E. KOTTLOWSKI

NEW MEXICO ENVIRONMENTAL EVALUATION GIOUP ROBERT H. NEILL

NEW YORE DEPT OF MEALTH DAVID AXELROD, M.D.

NEW YONU ENEERG RESEARCH \& DEVELOPMENT AUTHORTY JOHN P. SPATH (8)

NEN YORE GEOLOGICAL SURVEY ROBERT H. FAKUNDINY

NEW YORK POWER AUTHORTY MYRON M. KACZMARSKY

NEW YORK STATE ATTORNEY GENERALS OFFICE EZRA I. BIALIK

NEW YORK STATE ELECTEIC \& GAS CORP LEWIS L. STALEY

NEW YORK STATE ENERGY RESEARCH AND DEVELOPMENT AUTHOHITY JOHN C. DEMPSEY

NEW YORK STATE ENVIRONMENTAL FACILITIES CORP PICKETT T. SIMPSON

MEW YOFK STATE GEOLOGICAL SURVEY ROBERT H. FICKIES

NEW YORK STATE PUQLLC SERVICE COMMISSION FRED HAAC

NEYER, TISEO, \& HINDO LTD KAL R. HINDO

NORTH CAMOLNA CONSERYATION COUNCIL JANE SHARP

NORTH CAROLNA DEPT OF NATURAL PESOURCES \& COMMUNITY DEVELOPMENT STEPHEN G. CONRAD

NORTH CAEOUNA STATE UNIVERSTYY M. KIMBERLEY

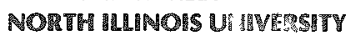
B. VON ZELLEN

NOWTHEAST OHO ROUE COUNTY MEGIONAL PLANMANG

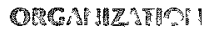

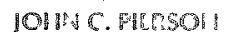

NORTHEAST UTHLITIES SERVICE COMPANY PATRICIA ANN OCONNELL

NTR GOVERNMENT SERVICES THOMAS V. REYNOLDS

NUCLEAR ASSURANCE CORP JEAN RION

NUCLEAR ENERGY AGENCY/ORCD - FRANCE ANTHONY MULLER

NUCLEAR INFORMATION AND RESOURCE SERVICE GARY HZKOWITZ

NUCLEAR SAFETY RESEARCH ASSOCIATION IZUMI KURIHARA

NUCLEAR SYSTEMS ASSOCIATES INC CHARLES J. DIVONA

NUCLEAR WASTE WATCHERS HELEN LETARTE

NUS CORP

W. G. BELTER

RODNEY J. DAVIS

N. BARRIE MCLEOD

DOUGLAS D. ORVIS

YONG M. PARK DOUGLAS W. TONKAY

NUTECH ENGINEERS INC GARRISON KOST PAUL C. SUN

OAK RIDGE NATIONAL LABORATORY J. O. BLOMERE

H. C. CLAIBORNE ALLEN G. CROFF

LESLIE R. DOLE JOHN T. ENSMINGER

CATHY S. FORE DAVID C. KOCHER

T. F. LOMENICK ARTHUR I. SHOR ELLEN D. SMITH E. G. ST CLAIR

OHIO DEPT OF HEALTH ROBERT M. QUILLIN

OHIO DEPT OF NATURAL RESOURCES SCOTT KEIL.

OMO ENVIRONMENTAL COUNCI STEPHEN H. SEDAM

OHIO ENVIRONMENTAL PROTECTION AGENCY

HAROLD W. KOHN

OHIO STATE UNIVERSETY R. N. CHRISTENSEN

OKLAHOMA GEOLOGICAL SURVEY CHARLES I. MANKIN

OKLAHOMA STATE DEPT OF HEALTH R. L. CRAIG

ONTAEO HYDRO - CANADA

R. W. BARNES

J. A. CHADHA

K. A. CORNELL

C. F. LEE

R. C. OBERTH

ONTARIO MINISTRY OF THE ENVIMONMENT CANADA

JAAK VIIRLAND

ONTARIO RESEARCM YOUNDATION -

CANADA

LYDIA M. LUCKEVICH

ORANGE COUNTY COMMUNITY COLLGE LAWRENCE E. OBRIEN

OREGON DEPT OR ENERGY MICHAEL W. GRAINEY

OREGON STATE UNIVERSITY BRIAN DODD

JOHN C. RINGLE 
ORGANISATION FOR RCONOMIC COOPERATION AND DEVELOPMENT FRANCE

PETER D JOHNSTON

OTHA INC JOSEPHA LIEBERMAN

P.O.W.E.R. RALPH DILLER

PACIFIC GAS AND ELECTRIC COMPANY ADRIAN C SMITH JR

PACIFIC NOETHWEST LARORATORY

W F BONNER

DON I BRADLEY

H C BURKHOLDER

L L CLARK

HARVEY DOVE

FLOYD N HODGES

I H IARRETT

MAX R KREITER

DONALDE LARSON

ROBERT MCCALLUM

$R$ WILLIAM NELSON

$R$ E NIGHTINGALE

I M RUSIN

E C WATSON

I H WESTSIK, IR

PARSONS RRINCKERHOFF QUADE \&

DOUGLAS INC

$T$ R KUESEL

ROBERT PRIETO

MARK E STEINER

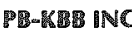

JUDITH G HACKNEY

PEN INC LARRY PENBERTHY

PENASYIVANIA GOVERNORS ENERGY COUNCIL HERBERT JACOBS

PENNSYLVANBA STATE UNVEERSITY MICHAEL GRUTZECK DELLAM ROY

PENASYIVANIA TOPOGRAPHIC \& GEOLOGICAL SURVEY ARTHUR A SOCOLOW

PERMMIAN $B A S I N$ REGIONAL PLANNING COMMISSION

E W CRAWFORD

PERYY COUNTY HOARD OF SUPERVISORS PAUL D JOHNSTON SR

PERPY COUNTY CITIZEASS AGAINST NUCLEAR

WASTE DISPOSAL

WARREN STRICKLAND PETTIS WALIEY

PERPY COUNTY SCHOOLS MANIEL A COCHRAN

PHYSIKALISCH-TECHNISCHE MUNDESANSTAIT

- W. GEEMANY PETER BRENNECKE HORST SCHNEIDER

PINE FOREST REGIONAL LIRRA

POINT REACH NUCLEAR PLANT JAMES I ZACH

PORTLAND GENERAL ELECTIIC J W LENTSCH

POTASH CORP OF SASKATCHEWAN CANADA

GRAEME G STRATHDEE

POWER REACTOR AND NUCLEA FUEL

DEVELOPMENT CORPORATION - IAPAN

PRESQUE ISLE COURTHOUSE

PUTHIC LAW UTHLTIES GROUP

DORIS FALKENHEINER
PUBLIC SERVICE INDIANA

ROBERTS WEGENG

PURDUE UNIVERSTTY

PAULS LYKOUDIS

QUADREX CORP

FRANCIS I KENESHEA

RADIATION PROTECTION COUNCIL TERI L VIERIMA

RALPH M. PARSONS COMPANY JERROLD A HAGEL

RANDALL COUNTY LIERARY

RAPPAMANNOCK AREA DEVRIOPMENT

COMMISSION

WILLIAM BAER

RE/SPLC INC

GARY D CALLAHAN

PAUL F GNIRK

WILLIAM C MCCLAIN

RENSSELAER POLYTECHANIC INSTITUTE JAMES WU

RHOADS MEMORIAL LIRRARY

MICHTON CITY HALL R RAHAIM

RIDUHALCH, RGCERS \& ASSOCIATES INC PHILIPE EGGERS

MIO ALGOM CORP DUANE MATLOCK

TSO NATHONAL LABORATORY - DENMARE LARS CARLSEN

MOCKWEL HANFORD OPERATIONS RONALD C ARNETT

G 5 BARNEY

R A DEIU

GEORGE C EVANS (2)

R I GIMERA

KUNSOO KIM

KARLM LARUE

STEVEN I PHILLIPS

MICHAELI SMITH

DAVID L SOUTH

DAVE A TURNER

ROCKWELL INTEANATIONAL ENEDG SYYSTEMS GROUP

HARRY PEARLMAN

LAWRENCEJ SMITH

ROGERS \& ASSOCIATES ENGINEERING CORP ARTHUR SUTHERLAND

ROGERS, GOLDEN \& HALPERN JACK A HALPERN

ROY F. WESTON INC MICHAEL $\checkmark$ MELLINGER HARRY W SMEDES

ROYAL INSTTTUTE OF TECHNOLOGY . SWEOEN

IVARS NERETNIEKS

ROGER THUNVIK

S.E. LOGAN \& ASSOCIATES INC STANLEYE LOGAN

S.M. STOLLER CORP ROBERT W KUPP

SALT LARE CITY PUELIC LURARY

SAN DIEGO GAS \& ELECTRIC COMPANY LOUIS BERNATH

SAN IOSE STATE UNIYETSTY SCHOOL OF ENGINEERING

R N ANDERSON

SAN IUAN COUNTY LISRARY

SANDIA NATIONAL LABORATORIES

LIBRARY

G C ALLEN

KEN BEALL
SHARLA BERTRAM

C L CHRISTENSEN

MARGARET S CHU

IOE A FERNANDEZ

$R$ L HUNTER

R W LYNCH

RUDOLPH V MATALUCC

IAMEST NEAL

E J NOWAK

SCOTT SINNOCK

A W SNYDER

A E STEPHENSON

DANIEL M TALBERT

LYNN D TYLER

WOLFCANG WAWERSIK

WENDELL D WEART

WIPP CENTRAL FILES

SAVANNAH RIVER LAEORATORY

E J HENNELLY

CAROL JANTZEN

I WENDELL MARINE

WILLIAM R MCDONELL

SCIAKY BROTHERS

JOHN C JASPER

SCIENCE APPLLICATIONS INC

JEFFREY ARBITAL

IERRY J COHEN

NADIA DAYEM

RALPH FULLWOOD

MICHAEL B CROSS

IAMES E HAMMELMAN

DEAN C KAUL

I ROBERT LARIVIERE

DAVID H LESTER

PETER E MCGRATH

JOHNE MOSIER

HOWARD PRATT

MICHAEL E SPAETH

KRISHANK WAHI

ROBERT A YODER

SCRHPPS INSTITUTE OR OCEANOGHAPHY

(A-\$15)

HUBERT STAUDIGEL

SENECA COUNTY DEPT OF PLANNANG \&

DEVELOPMENT

SHIMIZU CONSTRUCTION COMBANY LTE JUN]I TAKAGI

SHIMIZU CONSTRUCTION COMPANY LTD IAPAN

TAKASHI ISHII

SEERRA CLUB

MARVIN RESNIKOFF

SIERRA CLUE - COLORADO OPEN SPACE COUNCIL

ROY YOUNO

SIERRA CLUB - MISSISSIPPPI CHAPTER

SIMECSOL CONSULYNG ENGINEERS - PRANCE MATTHEW LEONARD

SIX-COUNTY COMMISSIONERS

ORGANIZATION

G ALLEN FAWCETT

SNAKE WIVER ALLIANCE TIM MCNEIL

SOGO TECHNOLOGY INC TIO C CHEN

SOLUTION MINING RESEARCH ANSTTEUTE INC HOWARD W FIEDELMAN

SOUTH CAROLNA GEOIOGICAL SUIVVEY NORMANK OLSON

SOUTH DAKOTA GEOLOGICAL SUPVEY RICHARD BRETZ 
SOUTH DAKOTA OFFICE OF ENERGY POLICY STEVEN M WEGMAN

SOUTHWEST RESEARCH AND INFORMATION CENTER DON HANCOCK

ST \& E TECHNICAL SERVICES INC STANLEYM KLAINER

ST. BONAVENTURE UNIVERSTTY CARL I TWAROG

ST. JOSEPH COLLEE CLAIRE MARKHAM

ST. MARTIN HIGH SCHOOL RAYMOND \& WERTHNER

STANFORD UNIVERSITY KONRAD B KRAUSKOPF IRWIN REMSON

STATE UNIVERSITY OF NEW YORK COLLEGE AT CORTLAND JAMESE BUGH

STEADMAN \& HECTOR, P.A. ALICE G HECTOR

STEARNS-ROGER SERVICES INC VERYL ESCHEN

STONE \& WEBSTER ENGINEERING CORP JOHN H PECK ARLENE C PORT EVERETT M WASHER

STUDIO GEOLOGICO FOMAR - ITALY A MARTORANA

STUDSVIK ENERGITEKNIIK AR - SWEDEN AKE HULTGREN ROLF SIOBLOM

SUMMIT COUNTY ENVIRONMENTAL SERVICES JAMES T KING

SWANSON ENVIRONMENTAL INC PETER G COLLINS

SWISHER COUNTY LIRHARY

SWISS FEDERAL OFFICE OF ENERGY $\checkmark$ NIEDERER

SYRACUSE UNIVERSITY WALTER MEYER

SYSTEM DEVELOPMENT CORP RICHARD BALSAM

H G DAVIS RHONNIE L SMITH

SYSTEMS SCIENCE AND SOFTWARE PETER LAGUS

T.M. GATES INC TODD M GATES

TECHNICAL BNFORMATION PROJECI DONALD PAY

TECHNICAL RESEARCH CENTRE OF FINLAND OLLI I HEINONEN SILIA RUMMUKAINEN KARI SAARI SEPPO VUORI

TEKNEKRON RESEARCH INC DOUGLAS $K$ VOGT

TELEOWE PIPE TOBY A MAPLES

TEREA TEK INC NICK BARTON DANIEL D BUSH

TEXAS A \& M UNVVERSITY JOHN HANDIN ROY W HANN, IR STEVE MURDOCK JAMESE RUSSELL

TEXAS DEPT OF HEALTH DAVIDK LACKER
TEXAS DEPT OF WATER RESOURCES

C R BASKIN

ALFRED DAREZZO

TEXAS ENERGY \& NATURAL RESOURCES

ADVISORY COUNCIL TERRY BARRON

TEXAS ENERGY COORDINATORS OFFICE ARNULFO ORTIZ

TEXAS FARM BUREAU RESEARCH DEPT W C WEDEMEYER

TEXAS GOVERNORS OFFICE STEVE FRISHMAN

TEXAS GOVERNORS OFFICE OF GENERAL COUNSEL

R DANIEL SMITH

TEXAS HOUSE OF REPRESENTATIVES ELLLEN SALYERS

TEXAS RADIATION ADVISORY BOARD LAURA KEEVER

TEXAS STATE HOUSE OF REPRESENTATIYES PETE LANEY

THE AEROSPACE CORPORATION PETER I ALEXANDRO

THE ANALVIIC SCIENCES CORP JOHN W BARTLETT CHARLES M KOPLIK

THE EARTH TECHNOLOGY CORP JOSEPH G GIBSON

MATT WERNER KENNETH L. WILSON

THE IACKSON CLARION-LEDGER MARK SCHLEIFSTEIN

THOMSEN ASSOCIATES C T GAYNOR, II

TRANSNUCLEAR INC BILL R TEER

TRENDS PUBLISHING INC

TRINITY EPISCOPAL CHURCH BENIAMIN F BELL

TRU WASTE SYSTEMS OFFICE $K \vee$ GILBERT

TRW INC PETER ALEXANDER E R CHRISTIE

U.H.D.E. - W. GERMANY FRANK STEINBRUNN

U.S. ARMY CORPS OF ENGINEERS JOHN BOWMAN JR ALAN BUCK

U.S. BUREAU OF LAND MANAGEMENT LYNN IACKSON MARY PLUMB EDWARD R SCHERICK GREGORY F THAYN

U.S. BUREAU OF MINES GEORGE E NIEWIADOMSKI

U.S. BUREAU OF RECLAMATION REGE LEACH

U.S. DEPT OF COMMERCE ALEXANDER MALAHOFF PETER A RONA

U.S. DEPT OF ENERGY $R$ COOPERSTEIN $S H$ GREENLEIGH LAWRENCE H HARMON IAMES TURI

U.S. DEPT OF ENERGY - ADEUQUERQUE OPERATIONS OFFICE PHILIP LARRAGOITE R LOWERY IOSEPHM MCGOUGH DORNER T SCHUELER
U.S. DEPT OF ENERGY - CHICAGO OPERATIONS OFFICE

D BRAY

NURI BULUT

DUANE DAY

PAUL KEARNS

PUBLIC READING ROOM

$R$ SELBY

U.S. DEPT OF ENERGY - CRYSTALLINE ROCK PROIECT OFFICE

STEVEN A SILBERGLEID

U.S. DEPT OF ENEREY - DALLAS SUPPORT OFFICE

CURTISE CARLSON IR

U.S. DEPT OF ENEIEY - DIVISION OF WASTE REPOSITORY DEPLOYMENT JEFF SMILEY

U.S. DEPT OF ENERGY - GROLOGIC REPOSITORY DIVISION

I W BENNETT

C R COOLEY (2)

WARREN EISTER

IMMFIORE

MARK W FREI

CRITZH GEORGE

RALPH STEIN

U.S. DEPT OF ENERGY - HEADQUARTERS PUBLIC READING ROOM

U.S. DEPT OF ENERGY - IDAHO OPERATIONS OFFICE

$M$ BARAINCA

CARL P GERTZ

JAMES F LEONARD

CARL R ROBERTSON

PUBLIC READING ROOM

I H SAKO

U.S. DEPT OF ENERGY - MATERIALS SCIENCE DIVISION

R I COTTSCHAL

U.S. DEPT OF ENERGY - NEVADA OPERATIONS OFFICE

I B COITER

PUBLIC READING ROOM

U.S. DEPT OF ENEMGY - NUCLEAR

ENVIRONMENTAL APPLICATION BRANCH ROBERT W BARBER

U.S. DEPT OF ENERGY - NUCLEAR WASTE

POLICY ACT OFFICE

ROBERT M ROSSELLI

IANIE SHAHEEN

U.S. DEPT OF ENERGY - NWTS PHOCRAM OFEICE

$1 O$ NEFF

U.S. DEPT OF ENERGY - OAK RIDGE OPERATIONS OFFICE PUBLIC READING ROOM

U.S. DEPT OF ENEEGY - OFFICE OF EASHC ENERGY SCIENCES MARK W WITTELS

U.S. DEPT OF ENEEGY - OFFICE OF DEFENSE WASTE AND BYPMYODUCTS G K OERTEL

U.S. DEPT OF ENERGY - OPFICE OF PROIECT AND FACILUTES MANAGEMENT D L HARTMAN

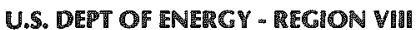
SIGRID HIGDON

U.S. DEPT OF ENEIRY - IICHLAND OPERATIONS OFFICE

O L OLSON

I SCHREIBER

D I SQUIRES 
U.S. DEPT OF ENERGY - SAN FRANCISCO OPERATIONS OFIICE

ENERGY RESOURCES CENTER LEN LANNI

PUBLIC READING ROOM

U.S. DEPT OF ENERGY - SAVANNAH RIVER OPERATIONS OFFICE $T$ B HINDMAN

U.S. DEPT OF ENERGV - TECHNICAL

INFORMATION CENTER (317)

U.S. DEPT OF LAEOR

ALEX G SCIULLI KELVINK WU

U.S. ENVIRONMENTAL PROTECTION AGENCY DIVISION OF CRITERIA \& STANDARDS DONALD HUNTER JAMES NEIHEISEL

U.S. GENERAL ACCOUNTING OFFICE WILLIAM DAVID BROOKS CHARLES D MOSHER

U.S. GEOLOGICAL SURVEY - ALEXANDIIA $G N$ RYALS

U.S. GEOLOGICAL SURVE - BATON ROUGE DARWIN KNOCHENMUS

U.S. GEOLOGICAL SURVEY - COLUMBUS A M LASALA IR

U.S. GEOLOGICAL SURVEY - DENVER JESS M CLEVELAND

$G$ L DIXON

$S S$ GOLDICH

W SCOTT KEYS ROBERT A ZIELINSKI

U.S. GEOLOGICAL SURVEY - IACKSON GARALD G PARKER IR

U.S. GEOLOGICAL SURVEY - MENLO PAFIK JOHN BREDEHOEFT

J BYERLEE

MICHAEL CLYNNE

JACOB RUBIN

U.S. GEOLOGICAL SURVEY - MESTON

I-MING CHOU

JOHN ROBERTSON

EDWIN ROEDDER

EUGENE H ROSEBOOM IR

PETER R STEVENS

DAVID B STEWART

NEWELL I TRASK IR

U.S. MOUSE SUPCOMMITTEE ON ENERGY AND

THE ENUVRONMENT

MORRISK UDALL

U.S. NUCLEAR REGULA TOEY COMMISSION

J CALVIN BELOTE

R BOYLE

EILEEN CHEN

ENRICO F CONTI

F R COOK

I) DAVIS

DOCKET CONTROL CENTER

PAULF COLDBERC

LUDWIG F HARTUNC

HIGH-LEVEL WASTE LICENSING BRANCH

HIGH-LEVEL WASTE TECH DEVELOP

BRANCH

ROBERT JOHNSON

CIVDE JUPITER

PHILIPS JUSTUS

H E LEFEVRE

IOHN C MCKINLEY

THOMAS I NICHOLSON

EDWARD OCONNELL

JAYE RHODERICK

$R$ JOHN STARMER

MICHAEL WEBER

KRISTIN B WESTBROOK
U.S. SENATE COMMITEE ON ENERGY AND NATURAL RESOURCES

WILLIS D SMITH

UNION CARIIDE CORP

BLYNN E PRINCE

JOHN D SHERMAN

UNION COLLEGE

I R SHANEBROOK

UNION OF CONCERNED SCIENTISTS MICHAEL FADEN

UNITED KINGDOM DEPT OF THE

ENVIRONMENT

F S FEATES

RADIOACTIVE WASTE MANAGEMENT DIVISION

UNIVERSITY OF ARIZONA

JAAK DAEMEN

JAMES G MCCRAY

SHLOMO P NEUMAN

ROYG POST

UNIVERSITY OF RRITISH COLUMBIA -

CANADA

CRAIG FORSTER

UNIVERSITY OF CALFORAIA AT BERRRELE

NEVILLE G W COOK

TODD LAPORTE

BIORN PAULSSON

UNIVERSITY OF CALIFORNIA AT LOS ANGELES D OKRENT

UNIVERSITY OF CALIFORNIA AT RIVERSIDE LEWIS COHEN DON STIERMAN

UNIVERSITY OF DELAWARE FRANK A KULACKI

UNIVERSITY OF FLORIDA

DAVID E CLARK

DOLORES C JENKINS

M I OHANIAN

UNIVERSITY OF HAWAII AT MANOA

DAVID EPP

MURLIH MANGHNANI

UAIVERSITY OF ILLINOIS AT URBANA -

CHAMPAIGN

DANIEL F HANC

ALBERT I MACHIELS

MACDI RAGHE

UNIVEFSITY OF LOWELL JAMES R SHEFF

UNIVERSITY OF MARVLAND

AMERICAN NUCLEAR SOCIETY

MARVIN ROUSH

UNIVERSTTY OF MICHIGAN RICHARD C PORTER

UNIVERSITY OF MINNESOTA RAYMOND STERLINC I K TYLKO

UNIVERSITY OF MISSISSIPPI GEORGE D BRUNTON

UNIVERSITY OF MISSOURI AT KANSAS CITY EDWIN D GOEBEL SYED E HASAN

UNIVERSITY OF MISSOURI AT ROLLA ALLEN W HATHEWAY ARVIND KUMAR NICK TSOULFANIDIS

UNIVERSSTY OF NEVADA AT RENO RODNEY / WEICK BECKY WEIMER-MCMILLION

UNIVERSTTY OF NEW MEXICO DOUGLAS G BROOKINS RODNEY C EWING
UNIVERSTTY OF NORTH CAROLINA

PAUL D FULLAGAR

UNIVERSITY OF NOTRE DAME JOHN I UCEY

UNIVERSITY OF OTTAWA - CANADA TUNCER OREN

UNIVERSITY OF PITTSBURGH B L COHEN

UNIVERSITY OF SOUTHERN MISSISSIPPI CHARLES R BRENT FRED HOWELL

JAMESW PINSON DANIEL A SUNDEEN GARY C WILDMAN

UNIVER SITY OF TENNESSEE AT KNOXVILE I B FUSSELL.

UNIVERSITY OF TEXAS AT AUSTIN BUREAU OF ECONOMIC GEOLOGY THOMAS C GUSTAVSON MARTIN P A IACKSON

DALE KLEIN

JOE O LEDBETTER

THE GENERAL LIBRARIES E G WERMUND

UNIVERSITY OF TEXAS AT SAN ANTONIO DONALD R LEWIS

UNIVERSITY OF TOKYO - IAPAN RYOHEI KIYOSE

UNIVERSTTY OF TORONTO - CANADA

N S BRAR

$R$ M STESKY

UNIVERSITY OF UTAH MARRIOTT LIBRARY GARYM SANDQUIST RODGER WEAVER

UNIVERSTIY OF UTAH RESEA RCH INSTTTUTE LIBRARY

UNIVERSITY OF WASHINGTON

DAVID BODANSKY

$M$ A ROBKIN

UNIVERSTTY OF WESTERN ONTARIO -

CANADA

WILLIAM S FYLE

P W M JACOBS

UNIVERSITY OF WISCONSIN

B C HAIMSON

UNIVERSITY OF WISCONSIN AT FOND DU LAC JOHN B HELL

UNIVERSITY OF WISCONSIN AT MLLWAUKEE HOWARD PINCUS

URS/JOHN A. MLUME \& ASSOCIATES, ENGINEERS ANDREW B CUNNINGHAM

UTAM BUREAU OF RADIATION CONTIROL DARRELL M WARREN

UTAH DEPT OF NATURAL MESOURCES \& ENERGY

MARK A PAGE

UTAH DIVISION OF PARKS \& RECREATION CORDON W TOPHAM

UTAH GEOLOGICAL AND MENERAL SURVEV GENEVIEVE ATWOOD MAGE YONETANI

UTAH SCIENCE COUNCII RANDYMOON

UTAH SOUTHEASTERN DISTRICT HEALTH

DEPARTMENT ROBERT L FURLOW

UTAH STATE UNIVEESSTY DEPT OF GEOLOGY 07

UTHLTY DATA INSTITUTE FRFD YOST 


\author{
VANDEREILT UNIVERSITY \\ FRANK L. PARRER \\ VEPCO \\ B. H. WAKEMAN \\ VERMONT DEPT OF WATER RESOURCES AND \\ ENVIRONMENTAL ENGINEERING \\ CHARLES A. RATTE \\ VERMONT STATE NUCLEAR ADVISORY PANEL \\ VIRGINIA CALLAN \\ VIRGINIA DEPT OF HEALTH \\ ROBERT G. WICKLINE \\ VRRGNIA POLYTECHNICAL INSTITUTE AND \\ STATE UNIVERSITY \\ GARY L. DOWNEY \\ WASHINGTON COUNTY ENVIRONMENTAL \\ COUNCIL \\ CAROLYN JOHNSON \\ WASHINGTON DEPT OF SOCIAL AND HEALTH \\ SERVICES \\ T. STRONG \\ WASHINGTON HOUSE OF REPRESENTATIVES \\ RAYISAACSON \\ WASHINGTON STATE UNIVERSTTY \\ GEORGIA YUAN \\ WATTLA \\ BOB E. WATT
}

WAYNE STATE UNIVERSTTY

IAMES A. WOODYARD

WRAI-FM

WARREN LIEBOLD

WEBSTER PAIISH LIBRARY

WEST DADE REGIONAL LIBRARY

LOURDES BLANCO LOPEZ

WEST VALBEY NUCLEA SERVICES CO INC CHRIS CHAPMAN

ERICH J. MAYER

RICHARD M. WINAR

WEST VIRGINIA GEOLOGICAL AND

ECONOMIC SURVEY

ROBERT B. ERWIN

WESTINGHOUSE ELECTRIC CORP

GEORGE V. B. HALL

CAROL A. KIZIS

KENNETH C. RADFORD

IAMES H. SALING

JAMES R. SCHORNHOUST

WIPP PROIECT

WESTINGHOUSE ELECTRIC CORPORATION

WISCONSIN DEPT OF NATURAL RESOURCES DUWAYNE F. GEBKEN
WISCONSIN DIVISION OF STATE ENEEG ROBERT HALSTEAD

WISCONSIN GEOLOGICAL AND NATURAL HISTORY SURVEY

MICHAEL G. MUDREY, JR.

MEREDITH E. OSTROM

WISCONSEN PUBLIC SERVICE CORP PAUL WOZNIAK

WISCONSIN RADIOACTIVE WASTE REVIEW BOARD

JAME SCHAEFER

WOODWARD-CLYDE CONSULTANTS

F. R. CONWELL (2)

ASHOK PATWARDHAN

WESTERN REGION LIBRARY

WP-SYSTEM AB - SWEDEN

IVAR SAGEFORS

WYOMING GEOLOGICAL SURYEY

JAMES C. CASE

YALE UNIVERSTTY

BRIAN SKINNER 